\title{
Sentidos da emancipação: \\ Para além da antinomia revolução versus reforma
}

\author{
Rúrion Soares Melo
}

Tese apresentada no Departamento de Filosofia da Faculdade de Filosofia, Letras e Ciências Humanas da USP para a obtenção do grau de Doutor em Filosofia, sob a orientação do Prof. Dr. Ricardo Terra.

\section{São Paulo}




\section{Resumo}

A tradição socialista foi marcada pela antinomia revolução versus reforma do capitalismo. Contudo, tanto a orientação revolucionária quanto a reformista perseguiram a utopia da sociedade do trabalho, fundamentando seu conceito de emancipação a partir de um paradigma produtivista. Este paradigma foi responsável por encobrir a articulação entre emancipação e democracia radical ao reduzir o núcleo normativo da autonomia ao modelo de ação baseado no trabalho - como ocorreu com a orientação revolucionária - ou engessando a autodeterminação política ao domesticar a democracia com as intervenções do poder administrativo - tal como ocorreu no caso da orientação reformista. Pretendemos mostrar que, além de se voltar contra as determinações impostas pelo paradigma da produção, a emergência de novos conflitos sociais e de lutas por reconhecimento não podem mais ser explicadas a partir de um único sentido de emancipação. A reconstrução da autocomprensão política de sociedades modernas a partir do projeto de uma democracia radical nos permite entender os diferentes sentidos da emancipação articulados em processos de formação política da opinião e da vontade. A utopia da sociedade do trabalho dá lugar às lutas em torno da integridade e autonomia das formas de vida, espaços de autorealização, conquistas de direitos e autodeterminação política. 


\begin{abstract}
The socialist tradition was marked by the antinomy revolution versus reform of capitalism. However, as much as the revolutionary orientation, the reformists also pursued the utopie of labor society, and grounded its concept of emancipation in a paradigm of production. This paradigm was responsable for covering the articulation between emancipation and radical democracy and reducing the normative core of the autonomy to the model of action based on labor - as in the case of the revolutionary orientation - or weakning the political selfdetermination and domesticating the democracy trough interventions of the administrative power - as in the case of the reformist orientation. We intend to show that, beyond facing against the determinations imposed by the paradigm of production, the emergency of new social conflicts and struggles for recognition can not be explained from only one sense of emancipation. The reconstruction of the political selfunderstanding of modern societies from a project of radical democracy allow us to understand the diferent senses of emancipation articulated in political processes of opinion and will formation. The utopie of labor society gives place to the struggles for the integrity and autonomy of forms of life, spheres of selfrealization, conquests of rights, and political selfdetermination.
\end{abstract}




\section{Agradecimentos}

A presente tese resultou, antes de tudo, de pesquisas e discussões vinculadas ao Projeto Temático FAPESP "Moral, política e direito: Modelos de teoria crítica", e desenvolvido junto ao CEBRAP, coordenado pelo Prof. Dr. Marcos Nobre. Agradeço a todos os membros do grupo pelas críticas e opiniões feitas em etapas importantes da pesquisa e pela oportunidade de partilhar de um ambiente interdiscilplinar sem o qual eu não teria conseguido dar unidade às diversas perspectivas teóricas sobre as quais tive de me debruçar.

Ao Prof. Dr. Axel Honneth, pelo convite e estágio de pesquisa na Johan-Wolfgang Goethe Universität Frankfurt am Main, período no qual pude desenvolver estudos importantes ligados aos temas da tese.

Ao Prof. Dr. Sérgio Costa, não apenas pela recepção e apoio que recebi na Freie Universität Berlin, mas também pelo acolhimento intelectual em um frutífero espaço de debate.

Ao Prof. Dr. Olivier Voirol, quem permitiu que eu ampliasse o círculo de discussões ao me receber no Institut für Sozialforschung em Frankfurt am Main.

Ao pessoal do Grupo de Filosofia Alemã do Departamento de Filosofia da USP, coordenado pelo Prof. Dr. Ricardo Terra, onde há muito mantenho um espaço de interlocução rico para minha formação.

Às amigas e amigos com quem compartilhei minhas motivações e dificuldades e que contribuíram, cada qual a seu modo, para a elaboração da tese, principalmente Maurício Keinert, Luiz Repa, Marisa Lopes, Felipe Gonçalves Silva e Fernando Mattos. Gostaria ainda de agradecer a Bruno Nadai, Paulo Mattos, José Rodrigo Rodriguez, Monique Hulshof, Nathalie Bressiani, José Carlos Estevão, Flamarion Caldeira Ramos, Inara Marim, Luciano Gatti, Sebastião Nascimento, Yara Frateschi, Igor Silva Alves, Raquel Weiss, Anderson Gonçalves, Soraya Nour, Omar Ribeiro Thomaz, Evorah Lusci, Bruno Simões, Francisco Gaspar, Marta Machado, Ricardo Crisciúma, Fernando Rugitsky, Gustavo Pimentel, Erinson Otênio e Jonas Medeiros.

Aos Profs. Drs. Marcos Nobre e Denilson Werle que compuseram a banca de qualificação e cujas críticas e sugestões foram definitivas para uma melhor formulação das idéias e elaboração final da tese. Minha dívida intelectual vai além dos limites do presente trabalho. 
Ao Prof. Dr. Ricardo Terra, a quem devo muito mais do que o agradecimento pela orientação paciente e sempre atenciosa.

A todo pessoal da Secretaria do Departamento de Filosofia da USP, principalmente Mariê Pedroso e Maria Helena, sem as quais tudo teria sido bem mais difícil.

A FAPESP, pela bolsa de doutorado concedida e pelo financiamento de meu estágio na Alemanha.

À minha família em especial, pelo apoio incondicional durante minhas idas e vindas.

A Patricia, por continuarmos tocando a mesma música... 


\section{Índice}

Introdução 9

\section{Parte I - A utopia da sociedade do trabalho: Crítica ao paradigma produtivista de emancipação}

Capítulo 1 - Emancipação e revolução 25

I - Autovalorização do capital: Dissolução sociológica do direito e da democracia 29

1. Base econômica e superestrutura política: A anatomia da sociedade civil em Marx ... 29

2. A compreensão funcionalista da democracia e a auto-organização holista dos trabalhadores 39

II - O conceito do político como epifenômeno das relações econômicas ............................. 54

1. A determinação econômica da política na teoria das classes ........................................ 57

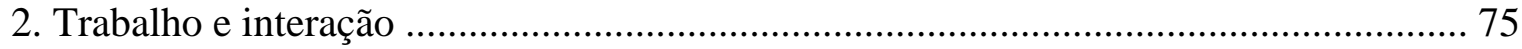

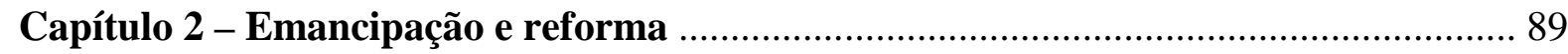

I - Capitalismo tardio e democracia: O programa do Estado de bem-estar social ............... 95

1. Justiça social e humanização do trabalho: O lado substancial do programa

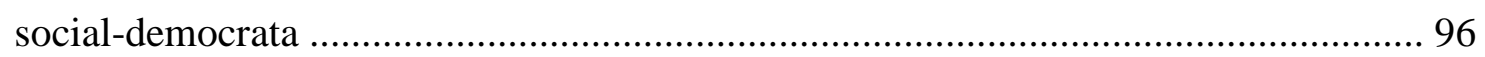

2. A domesticação do capitalismo: O lado metodológico do programa

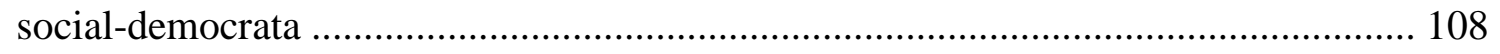

II - O conceito do político como mero poder administrativo: A crise de legitimação

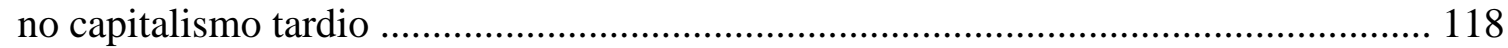

1. Colonização, reificação e juridificação ............................................................... 118

2. Para uma nova divisão de poderes na esfera da integração social:

Valor de troca, poder administrativo e solidariedade 134 
Parte II - Democracia radical: Para além da antinomia revolução versus reforma

Capítulo 3 - Emancipação e democracia radical ...................................................... 148

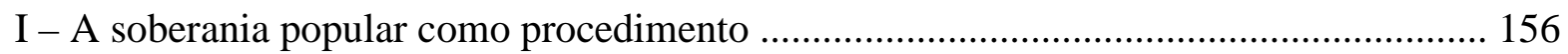

1. Novos movimentos sociais e a ampliação da agenda política da esquerda ................. 156

2. Excurso: O núcleo normativo do socialismo e a autonomia das formas de vida ........ 176

3. Esfera pública e o processo de circulação do poder político ....................................... 183

II - Interdependência e relação recíproca entre política e direito ....................................... 192

1. O modelo procedimental de política deliberativa ......................................................... 193

2. Lutas por reconhecimento no Estado democrático de direito ..................................... 199

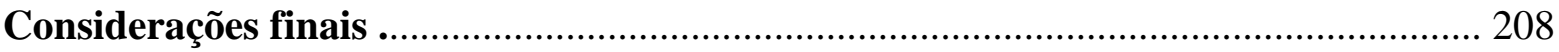

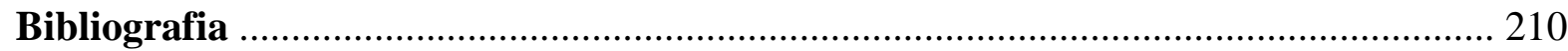


Na consciência revolucionária está inscrita a melancolia - a tristeza pelo fracasso de um projeto todavia irrenunciável.

Jürgen Habermas 


\section{Introdução}

No seu artigo "Revolução recuperadora e a necessidade de revisão da esquerda", escrito por ocasião dos acontecimentos e das transformações ocorridas no leste europeu no final da década de oitenta, Habermas comentou que "a esquerda não-comunista não tem motivo algum para a depressão. Pode ser que alguns intelectuais da RDA tenham primeiramente de se adaptar a uma situação em que a esquerda da Europa ocidental se encontra há décadas - ter de transformar as idéias socialistas em autocrítica radicalmente reformista de uma sociedade capitalista que, juntamente com suas fraquezas, desenvolveu suas forças nas formas de uma democracia de massas do Estado social e democrático de direito. Depois da falência do socialismo de Estado, essa crítica é o único buraco de agulha através do qual tudo tem de passar" ". Essa questão colocada por Habermas nos servirá como fio condutor para investigarmos de que modo é possível continuar formulando uma perspectiva a partir da qual os obstáculos à emancipação ou potenciais emancipatórios, quando presentes numa dada sociedade, sejam considerados e analisados de modo crítico. Nosso ponto de partida mais geral consiste, portanto, em pensar novamente o problema de como a esquerda poderia revisar ${ }^{2}$ suas inspirações teóricas e suas intuições normativas partindo de um diagnóstico sobre o Estado democrático de direito vinculado ao Ocidente capitalista.

Se, por um lado, a autocrítica radical não implicaria assumir que o socialismo real continha as fontes normativas do projeto emancipatório, por outro lado, isso não significou que a alternativa de um Estado democrático de capitalismo tardio se apresentou como uma solução não problemática. Ou seja, se o sentido da emancipação não naufragou junto com a

\footnotetext{
${ }^{1}$ Habermas, J. "Die nachholende Revolution und linker Revisionsbedarf: Was heißt Sozialismus heute?". In: Habermas, J. Die nachholende Revolution. Frankfurt/M: Suhrkamp, 1990, p. 203.

${ }^{2}$ Segundo a entendemos, a idéia de uma "necessidade de revisão da esquerda" não pode ser compreendida se a vinculamos simplesmente às concepções conhecidas como "revisionistas". Axel Honneth e Urs Jaeggi chamam atenção ao fato de que, no diálogo com o marxismo em especial (embora não unicamente), os termos "revisão" e "reconstrução" podem encontrar um sentido comum. Por um lado, reconstrução significa considerar que a teoria marxista necessita de uma revisão cuja finalidade consistiria em desenvolver os potenciais nela presentes que ainda não se esgotaram; por outro lado, significa reavaliar tal teoria de um ponto de vista prático-político, ou seja, segundo suas "conseqüências políticas" atuais. Portanto, essas reflexões implicariam saber "como o materialismo histórico teve de ser definido (...) e como pode ser definido hoje". Honneth, A./Jaeggi, U. (Org.). Theorien des Historischen Materialismus. Frankfurt/M: Suhrkamp, 1977, p. 10-11. Tomando por base o conceito de reconstrução tal como se encontra na teoria de Habermas, podemos pensar também o sentido dessa revisão como uma "adaptação reconstrutiva da teoria marxista", como sugerido em Tomberg, F. Habermas und der Marxismus. Würzburg: Königshausen \& Neumann, 2003, p. 19. Sobre o conceito de reconstrução, ver especialmente Repa, L. A transformação da filosofia em Jürgen Habermas: Os papéis de reconstrução, interpretação e crítica. São Paulo: Esfera Pública, 2008, capítulo 3.
} 
experiência concreta de um socialismo de Estado, e também não se encontrava do lado oposto, atrelado à tradição liberal das sociedades capitalistas - concepção esta que hoje vê a si mesma como vencedora, pois, "do ponto de vista dos liberais, tudo o que era aproveitável do socialismo foi realizado na era da social-democracia"3. Pelo contrário.

Sabemos que os debates em torno dos ideais socialistas foram articulados, sobretudo, pela antinomia da revolução ou reforma do capitalismo. Muitos autores reconhecem que essa antinomia entre comunismo revolucionário e reformismo social-democrata, que dominou os termos do debate sobre a esquerda no século XX, estava situada nesse campo ${ }^{4}$. Em linhas gerais, os comunistas acusavam os reformistas social-democratas por terem traído os interesses da classe trabalhadora ao abandonarem o fim último da transformação revolucionária do capitalismo. Os social-democratas procuravam justificar caminhos alternativos para se imaginar uma sociedade na qual se pudesse combinar a intervenção do Estado com o mercado com a finalidade de alcançar uma redistribuição mais centralizada de recursos e prover assim mais oportunidades para a vida. Contudo, apesar dessa antinomia, ambos se preocupariam prioritariamente com os melhores meios e estratégias de se alcançar uma distribuição socialmente mais justa e igual, mas não haveria um desacordo sobre o próprio fim último a ser alcançado, ou seja, à imagem de uma sociedade desigual configurada sob os efeitos negativos e injustos do capitalismo se opunha aquela de uma sociedade emancipada na qual reinaria a disposição mais justa e igualitária sobre os produtos do trabalho e as condições de sua implementação ${ }^{5}$.

Já há muito tempo o comunismo falhava em criar um sistema social e econômico viável, assim como falhou também em desenvolver procedimentos democráticos que permitissem a legitimidade do regime frente à população ${ }^{6}$. Por outro lado, os princípios social-democratas da igualdade, bem-estar e de intervenção do Estado no mercado, que durante muitos anos possibilitaram, apesar de seus inúmeros problemas, uma melhoria de vida para a grande parte das pessoas, vêem sua manutenção ser cada vez mais solapada não apenas pelos imperativos da abertura do mercado, mas por uma crise de legitimação, os quais atingem ao menos três importantes pilares de seu programa: o estatismo ${ }^{7}$, a economia

\footnotetext{
${ }^{3}$ Habermas, J. "Die nachholende Revolution und linker Revisionsbedarf: Was heißt Sozialismus heute?", op. cit., p. 188.

${ }^{4}$ Cf. Lemke, C./Marks, G. (ed.) The crisis of socialism in Europe. Durham, 1992, introdução.

${ }^{5}$ Essa abordagem centralizada na questão da revolução ou reforma do capitalismo é predominante mesmo em historiadores tais como Sasson, D. One hundred years of socialism. New York: The New Press, 1996; Eley, G. Forging democracy:The history of the left in Europe, 1850-2000. Oxford: Oxford University Press, 2002; e também Rosemberg, A. Democracia e socialismo. Global. 1999.

${ }^{6}$ Cf. Reis Filho, D. A. As revoluções russas e o socialismo soviético. São Paulo: UNESP, 2003, capítulos 5 e 6.

${ }^{7}$ Cf. Huhn, W. Der Etatismus der Sozialdemokratie. Freiburg: ça ira Verlag, 2003.
} 
keynesiana e a manutenção do bem-estar social ${ }^{8}$. Não demorou muito para que muitos anunciassem que "o socialismo está morto"”.

Discordamos juntamente com Habermas que tenhamos de "enterrar de vez o pequenino cadáver do gigante"10. Uma autoreflexão crítica sobre as orientações emancipatórias vinculadas ao socialismo nos levaria antes a adotar um outro caminho, permitindo-nos indagar se o sentimento de uma provável falência ou fracasso dos ideais da esquerda, ou mesmo de um desencantamento do socialismo de um modo geral, não resultaria antes das limitações de certos pressupostos comuns responsáveis por manter suas inspirações teóricas e intuições normativas predominantemente voltadas a um sentido de emancipação em particular, cujo potencial parece ter se esgotado. Não se trata simplesmente de admitir o discurso sobre um déficit democrático que marcaria tanto a realidade política quanto a herança teórica da esquerda em seu conjunto ${ }^{11}$, mas entender por que a predominância da antinomia revolução versus reforma do capitalismo na determinação dos termos do debate entre o marxismo revolucionário e o reformismo social-democrata conteria a razão mesma desse possível esgotamento. Em outros termos, pretendemos investigar se esse desencantamento do socialismo corresponderia antes aos limites de uma concepção de emancipação que teria mantido em sua pauta um paradigma produtivista como modelo para formas de vida emancipadas, o qual faria com que uma reflexão mais aprofundada sobre a democracia radical e as condições institucionais da realização da liberdade se tornasse um problema derivado.

$\mathrm{Na}$ verdade, tanto liberais como socialistas interpretaram a evolução das sociedades modernas fundamentalmente como sociedade do trabalho: "As tradições clássicas da sociologia burguesa e marxista partilharam a opinião de que o trabalho seria $o$ fato social central. Elas construíram a sociedade e sua dinâmica como "sociedade do trabalho",12. Isso significava atribuir a todas atividades sociais um fio condutor centrado na atividade econômica, estabelecendo a economia de mercado como a base da sociedade. A constituição da sociedade moderna fundada na economia delineava assim os planos de um projeto de

\footnotetext{
${ }^{8}$ Cf. Sasson, D. One hundred years of socialism, op. cit., p. 733.

9 Touraine, A. O pós-socialismo. Tradução de Sonia Gldfeder e Ramon Américo Vasques. São Paulo, Brasiliense, 2004., p. 15. Cf. também Bobbio, N. L’utopia capovolta. Torino: La Stampa, 1990; e Dahrendorf, R. Após 1989: Moral, revolução e sociedade civil. São Paulo, Paz e Terra, 1997. Há ainda a polêmica interpretação de Fukuyama, F. The end of history and last man. Penguim: London, 1992.

${ }^{10}$ Habermas, J. "Die nachholende Revolution und linker Revisionsbedarf: Was heißt Sozialismus heute?", op. cit., p. 188.

${ }^{11}$ Cf. Lemke, C./Marks, G. (ed.) The crisis of socialism in Europe, op. cit., p. xii.; e também Gottfried, P. The strange death of marxism. University of Missouri, 2005, p. 23 e 95.

12 Offe, C. “Arbeit als soziologische Schlüsselkategorie?”. In: Offe, C. Arbeitsgesellschaft: Strukturprobleme und Zukunftsperspektiven. Frankfurt/M: Campus, 1984, p. 13.
} 
modernidade que se tornaria explícito no estabelecimento do capitalismo. Pois "o capital subordina em seu próprio movimento, ou seja, no movimento de autovalorização regulada pelo lucro, todos os âmbitos e aspectos da sociedade - ele abre mercados e os organiza primeiramente na esfera nacional e em seguida na esfera internacional; ele organiza uma classe de trabalhadores industriais 'livres' - ou seja, separados de seus meios de trabalho $e$ emancipados da base feudal de sua força de trabalho - e se torna o fundamento de determinação exclusivo de suas condições de vida e de trabalho; ele desenvolve tecnologias e institucionaliza sua permanente renovação; ele reúne sistemas nacionais e internacionais e uma rede de relações de interdependência cada vez mais estreitas"13. A organização racional da empresa capitalista assenta, sobretudo, no trabalho formalmente livre e na expectativa de lucro, pela separação entre a empresa e a economia doméstica e, por fim, pela criação de uma contabilidade racional. O racionalismo econômico desencadeado pelo capitalismo se vincularia à racionalização cultural, devido ao emprego racional da ciência e da técnica, e também à racionalização do Estado e do direito, assentando-se na administração da justiça e no direito formal ${ }^{14}$.

Essa imagem de uma sociedade moderna delineava o avanço massivo do capitalismo industrial na economia mundial, as transformações radicais no estabelecimento da ordem social que o capitalismo representaria e também das idéias que legitimavam a visão de mundo em seu conjunto, tais como aquelas do esclarecimento, da ciência, do progresso e do liberalismo político: "a locomotiva se torna o símbolo popular de uma mobilização vertiginosa, interpretada como progresso, de todas as relações da vida"15. O capitalismo não se limitaria à representação do triunfo de uma sociedade que acreditava que o crescimento econômico estava apoiado simplesmente na competição dos interesses privados, mas teria possibilitado uma rica distribuição material e criado oportunidades humanas: esse desenvolvimento estabeleceria assim um padrão de racionalidade de uma vida boa, baseado na "utilização racional dos recursos ou distribuição igualitária dos meios de satisfação das necessidades" 16 . A modernidade se efetivaria por essa via como "um mundo do progresso material e moral, contínuo e acelerado"17. Ademais, sobre esse trabalho moderno se estabelecerá, seja para liberais ou para socialistas, não apenas a integração social, mas

\footnotetext{
13 Offe, C. "Spätkapitalismus - Versuch einer Begriffsbestimmung". In: Offe, C. Strukturprobleme des kapitalistischen Staates. Frankfurt/M: Suhrkamp, 1972, p. 10. Cf. Marx, K./Engels, F. Manifest der Kommunistischen Partei. In: Marx-Engels Werke. Band 4. Berlim: Dietz Verlag, 1964, p. 464 e ss.

${ }^{14}$ Cf. Weber, M. Die protestantische Ethik und der Geist des Kapitalismus. In: Gesammelte Aufsätze zur Religionssoziologie, Band 1. Tübingen: J. C. B. Mohr, 1986, introdução.

${ }^{15}$ Habermas, J. Der Philosophische Diskurs der Moderne. Frankfurt/M: Suhrkamp, 1985, p. 75.

${ }^{16}$ Offe, C. "Spätkapitalismus - Versuch einer Begriffsbestimmung”, op. cit., p. 16.

${ }^{17}$ Hobsbawm, E. The age of capital. 1848-1875. London: Abacus, 1977, p. 13.
} 
também a própria cidadania ${ }^{18}$. "Prometia-nos, a utopia industrialista", segundo André Gorz, "que o desenvolvimento das forças produtivas e a expansão da esfera econômica liberariam a humanidade da penúria, da injustiça e do mal-estar; que lhe dariam, com o poder soberano de dominar a natureza, o poder de determinar a si mesma; que fariam do trabalho a atividade demiúrgica e ao mesmo tempo autopoiética, na qual o aperfeiçoamento incomparavelmente singular de cada um seria reconhecido - direito e dever a um só tempo - como parte da emancipação de todos" $" 19$.

O outro lado da história manifesta, contudo, a unilateralidade da economia de mercado: a primeira Revolução Industrial não realizara a utopia de uma vida justa, mas a devastação social de um sistema incontrolado que reduziu o homem à força de trabalho ${ }^{20}$. Desde Marx já tomamos consciência dos efeitos colaterais disfuncionais e perigosos de uma sociedade que se moldara profundamente pelo trabalho abstrato, ou seja, trabalho remunerado, regido pelo mercado e organizado na forma capitalista. A crítica da economia política se esforçou em mostrar que o sistema econômico burguês criado impossibilitava a realização da liberdade e da igualdade no interior de sua lógica reprodutiva. Porém, se, por um lado, o processo de autovalorização do capital retirava dos indivíduos a capacidade de uma ação autônoma, pois submetia todos os âmbitos da vida ao seu próprio imperativo, o paradigma produtivista caracterizaria, por outro lado, também a condição de superação dessa situação de opressão e da restituição da própria autonomia ${ }^{21}$. Pois a revolução do modo de produção e de circulação obrigava os homens “a ver, com olhos realistas, suas posições na vida e suas relações recíprocas" ${ }^{22}$. Essa formulação implicava uma aceleração máxima da revolução das condições da vida, mas em um sentido positivo em que se postula um movimento social que livraria os homens da maldição de uma mobilidade imposta de fora. A autonomia só poderia ser restituída caso perseguíssemos "a guerra civil mais ou menos oculta no interior da sociedade existente até o ponto em que ela estoure em uma revolução aberta"23. $\mathrm{O}$ fio condutor tanto de uma mobilidade forçada como do ímpeto emancipatório consistiria no

\footnotetext{
${ }^{18}$ Cf. Castel, R. Les métamorphoses de la question sociale. Paris: Gallimard, 1999, p. 309 e ss; e Gorz, A. Metamorfoses do trabalho: Crítica da razão econômica. Tradução de Ana Montoia. São Paulo: Annablume, 2003, p. 20.

${ }^{19}$ Gorz, A. Metamorfoses do trabalho: Crítica da razão econômica, op. cit., p. 20.

${ }^{20}$ Cf. Polany, K. A grande transformação. Trad. De Fanny Wrobel. Rio de Janeiro: Elsevier, 2000.

${ }^{21}$ Cf. Féher, F./Heller, A. "Class, modernity, democracy”. In: Theory and society, 12, 1983, p. 211 e ss.

${ }^{22}$ Marx, K./Engels, F. Manifest der Kommunistischen Partei, op. cit., p. 465.

${ }^{23}$ Idem, p. 476.
} 
"rápido aperfeiçoamento dos intrumentos de produção", isto é, no desenvolvimento das forças produtivas $^{24}$.

Marx entendeu a própria forma de socialização não-capitalista segundo categorias do trabalho, ou seja, a capacidade que um sujeito socializado possui para dispor dos meios e dos processos materiais que configuram sua própria vida. A identificação do paradigma produtivista remetia a aspectos presentes em uma concepção de emancipação que solucionasse o problema do trabalho heterônomo: nessa linha de interpretação, a autonomia, ou autoatividade produtiva dos indivíduos ou das classes, só poderia ser alcançada quando os trabalhadores se apropriassem coletivamente da totalidade da produção, identificando, assim, emancipação e desenvolvimento das forças produtivas: aquela imagem da sociedade burguesa organizada pelo trabalho abstrato penetraria nessa outra configurada pelo arquétipo produtivista de uma comunidade de cooperação baseada na divisão igualitária do trabalho, e com isso as "expectativas utópicas também poderiam dirigir-se à esfera da produção, ou seja, para a emancipação do trabalho de toda determinação estranha" ${ }^{25}$. Em suma, afirmar que a crítica radical empreendida por Marx permanecia fixada dentro do horizonte da utopia da sociedade do trabalho significava que a revolução do capitalismo visava à possibilidade de constituição de uma reorganização social fundada novamente no trabalho, mesmo que de outro tipo. Pois "a libertação do trabalho heterônomo significa para tais utopias em geral não a libertação do trabalho. Pelo contrário: o trabalho permanece a substância da vida"26. Foi exatamente essa "visão utópica que penetrou o movimento operário e ainda nutre a ideologia do trabalho compartilhada pelas esquerdas clássicas"27.

Ao paradigma produtivista contrapomos, contudo, o diagnóstico de que "se esgotou a utopia da sociedade do trabalho",28 , ou seja, de que esta perdeu sua força persuasiva, mas não somente porque as forças produtivas perderam sua inocência ou porque a história mostrou que a abolição da propriedade privada dos meios de produção manifestamente não resultou por si só no governo autônomo dos trabalhadores, e sim porque a utopia haveria perdido seu ponto de referência na própria realidade, isto é, a força socializadora e estruturadora do trabalho abstrato $^{29}$. Tal diagnóstico foi fortemente influenciado pelos estudos sociológicos no quadro

\footnotetext{
${ }^{24}$ Idem, p. 473.

${ }^{25}$ Habermas, J. “Die Krise des Wohlfahrstaates und die Erschöpfung utopischer Energien”, op. cit., p. 162.

${ }^{26}$ Tomberg, F. Habermas und der Marxismus, op. cit., p. 332.

${ }^{27}$ Gorz, A. Metamorfoses do trabalho: Crítica da razão econômica, op. cit., p. 33.

${ }^{28}$ Cf. Habermas, J. "Volkssouveränität als Verfahren". In: Habermas, J. Faktizität und Geltung. Frankfurt/M: Suhrkamp, 1998, p. 602; e Habermas, J. "Die Krise des Wohlfahrstaates und die Erschöpfung utopischer Energien”, op. cit., p. 157.

${ }^{29}$ Cf. Habermas, J. "Konservative Politik, Arbeit, Sozialismus und Utopie heute”. In: Habermas, J. Die Neue Unübersichtlichkeit, op. cit., p. 66-76.
} 
do capitalismo tardio, os quais apresentaram "indicações da força objetivamente decrescente de fatores como trabalho, produção e lucro na determinação da constituição e do desenvolvimento da sociedade em seu conjunto" ${ }^{30}$. Embora uma parte crescente da população continue tendo de ser considerada trabalhadora, o trabalho abstrato possuiria cada vez menos força para determinar de forma unilateral o conteúdo de nossas ações tão diretamente quanto a teoria marxista pressupunha. As transformações econômicas, organizatórias e técnicas das condições de trabalho, e imanentes ao capitalismo tardio, indicariam que a centralidade da mercadoria força de trabalho dificilmente poderia continuar servindo como ponto de partida para a complexa explicação da integração social, das relações políticas e interpretações culturais $^{31}$. Nesse sentido, como lembra André Gorz, o esgotamento da utopia da sociedade do trabalho não representaria uma mera crise econômica, mas sim a indicação de que se desfaz o conjunto da utopia que há dois séculos nutre as sociedades industriais, ou seja, o esgotamento de uma visão do futuro a partir da qual uma civilização pautaria seus projetos, ancorando seus ideiais e suas esperanças ${ }^{32}$.

Segundo as formulações de Axel Honneth, também seria possível concluir a partir desse diagnóstico que "a base histórica da teoria da emancipação, no âmbito da qual Marx admite um vínculo entre emancipação e trabalho social, transformou-se de tal forma desde o século XIX que é difícil acreditar que alguma das teorias sociais com orientação crítica desse nosso século ainda confira ao processo do trabalho social uma força emancipatória capaz de formar empiricamente a consciência dos agentes. A mudança social das formas de trabalho liquidou ao mesmo tempo o próprio conceito do trabalho. (...) O conceito de trabalho (...) perdeu seu significado crítico e que transcendia as formas sociais de trabalho já estabelecidas. Por essa razão, as categorias de trabalho 'alienado' ou 'abstrato', com as quais Marx critica os modos capitalistas de organização do trabalho, praticamente desapareceram da linguagem teórica da filosofia social com orientação marxista" ${ }^{\text {,3 }}$. Mesmo aqueles que acreditavam na possibilidade de uma humanização ou emancipação do trabalho se voltariam a estudos relativos à cidadania, democracia ou cultura, pois o abismo entre a realidade social e as expectativas utópicas em torno do trabalho se aprofundaria a ponto de a teoria social crítica assumir a nulidade de seus esforços teóricos. "Com esta mudança de rumo", comenta Honneth

\footnotetext{
${ }^{30}$ Offe, C. "Arbeit als soziologische Schlüsselkategorie?”, op. cit., p. 20. Dentre a vasta literatura sobre o tema, apoiamo-nos também em Castel, R. Les métamorphoses de la question sociale, op. cit; Gorz, A. Metamorfoses do trabalho: Crítica da razão econômica, op. cit.; Wilson, W. J. When work disappears. New York: Handom House, 1996; e Senghaas-Knobloch, E. Wohin driftet die Arbeitswelt? Berlin Verlag, 2008.

${ }^{31}$ Cf. Offe, C. “Arbeit als soziologische Schlüsselkategorie?”, op. cit., p. 20-21.

${ }^{32}$ Cf. Gorz, A. Metamorfoses do trabalho: Crítica da razão econômica, op. cit., p. 20.

${ }^{33}$ Honneth, A. "Arbeit und instrumentales Handel". In: Honneth, A./Jaeggi, U. (org). Arbeit, Handlung, Normativität. Frankfurt/M, 1980, p. 213-214.
} 
em texto mais recente, "foi preparado o caminho para a situação diante da qual hoje abaladamente nos encontramos; situação em que a necessidade de todos aqueles que não apenas temem por seu posto de trabalho, mas também pela qualidade dele, não encontram mais ressonância no vocabulário de uma teoria crítica da sociedade" ${ }^{\text {34 }}$.

Esse diagnóstico implicaria duas possíveis interpretações da história dos efeitos presente em uma autocrítica do materialismo histórico. Primeiramente, na medida em que "esse pensamento procurou criticar a metafísica burguesa do trabalho", comenta Stefan Breuer, "também se movimentou no mesmo espaço homogêneo, abrangente e tradicional que a ideologia burguesa havia produzido" ${ }^{35}$. A teoria social crítica ligada ao marxismo ocidental recepcionaria essa continuidade de uma teoria da revolução presa ao conceito de trabalho como "crítica de falsas promessas" 36 . O próprio Marx teria de ser entendido como um dos principais nomes a contribuir para a análise crítica da sociedade capitalista, mas seria necessário abdicar de uma teoria da revolução, ou seja, de sua orientação emancipatória, caso não se libertasse da "metafísica do trabalho". Para a teoria social crítica contemporânea, o trabalho não teria potencial emancipatório, mas se apresentaria sempre como dominação: "segundo sua lógica interna, tal seria a consequiência dessa interpretação, a análise da forma do valor não consistiu em uma teoria da revolução, mas antes no conceito de sua impossibilidade: o que ela mostrou foi a submissão da sociedade sob a generalização de suas relações abstratas" ${ }^{, 37}$. Em segundo lugar, a interpretação marxista ortodoxa, de acordo com a qual a democracia consistiria em mero reflexo da base econômica, dificultou uma recepção dos textos de Marx na qual a teoria da revolução não fosse diretamente determinada pelo paradigma produtivista. Autores como Jean Cohen e John Rundell, por exemplo, críticos em face da centralidade das determinações economicistas, insistem em uma retomada de textos de Marx nos quais a práxis política ocuparia um lugar autônomo, fundamentando-se em um terreno diferente daquele da produção e do trabalho ${ }^{38}$. Essa atitude diante da recepção da obra de Marx, como veremos, permitiria encontrar já em seus próprios textos possíveis saídas para

\footnotetext{
${ }^{34}$ Honneth, A. "Trabalho e reconhecimento: tentativa de uma redefinição". Tradução de Emil Sobottka e Giovani Saavedra. In: Civitas. Porto Alegre, 8, 2008, p. 48. O próprio Honneth não exclui o conceito do trabalho como categoria para pensar a emancipação social, porém entende ser necessário superar o fundamento produtivista e explicar tal conceito a partir de sua teoria do reconhecimento.

${ }^{35}$ Breuer, S. Die Krise der Revolutionstheorie. Frankfurt/M: Syndikat, 1977, p. 11.

${ }^{36}$ Idem, p. 240 e ss.

${ }^{37}$ Idem, p. 17-18.

${ }^{38}$ Cf. Rundell, J. Origins of modernity: The origins of modern social theory from Kant to Hegel to Marx. Cambridge, 1987; e Cohen, J. Class and civil society: The limits of marxian critical theory. University of Massachussets Press, 1982.
} 
o empasse criado pelo paradigma produtivista como orientação emancipatória, a saber, a determinação da política como mero epifenômeno das relações econômicas.

A tarefa da autoreflexão da crítica social e de seu projeto de esquerda consistiria assim em "superar o paradigma produtivista, sem abrir mão das intenções do marxismo ocidental"39. Na formulação de Marcos Nobre, "as aporias da vertente 'de esquerda' do projeto moderno são índice da necessidade de reformular os termos do próprio projeto" ${ }^{40}$. Partindo das críticas propostas pela teoria social contemporânea à categoria do trabalho, pretendemos mostrar que o elemento crítico e emancipatório que perpassava o desenvolvimento das sociedades modernas consiste não na centralidade da gênese e no conjunto do processo de autovalorização do capital privilegiado pelo paradigma produtivista, mas no resgate do projeto de uma democracia radical, ou seja, no resgate de um projeto de autodeterminção e de autorealização pelas quais os próprios cidadãos seriam capazes de se organizar de forma livre e igual. "Se compreendemos "socialismo", diz Habermas, "como o conjunto de condições necessárias para formas de vida emancipadas, sobre as quais os próprios participantes têm de se entender preliminarmente, reconhece-se que a auto-organização democrática de uma comunidade de direito forma o núcleo normativo também desse projeto" ${ }^{\text {41 }}$. O marxismo revolucionário e o reformismo social-democrata não puderam reconhecer que em suas próprias orientações já se encontrava inscrito exatamente esse núcleo normativo: o primeiro porque, com a centralidade do paradigma produtivista, não pôde levar a termo o fato de que seus impulsos por autodeterminação radical já estavam presentes na herança dos movimentos burgueses por emancipação - herança que, apesar de ter sido por eles negada, lhes seria correspondente; o segundo porque, apesar de adotar a via de universalização da cidadania, simplesmente abdicou da democracia radical em detrimento de uma humanização do mundo do trabalho produzida pelas intervenções administrativas do Estado social. Nesse sentido, se a questão da democracia muitas vezes se tornou um problema derivado na teoria e na prática de revolucionários e reformistas, isso não ocorreu porque estaria intima e necessariamente inscrito nos pressupostos e motivações de suas concepções um déficit democrático, mas antes porque a plena realização da liberdade e da igualdade permaneceu vinculada à utopia da sociedade do trabalho. Desse modo, a questão da democracia precisaria ser recuperada. Pois, como formulou Albrecht Wellmer, "o núcleo autêntico do programa socialista pode sobreviver somente no interior do programa democrático; e isso significa, na verdade, que

\footnotetext{
${ }^{39}$ Habermas, J. "Ein Interview mit der New Left Review", op. cit., p. 217.

${ }^{40}$ Nobre, M. A Dialética Negativa de Theodor W. Adorno: A ontologia do estado falso. São Paulo: Iluminuras, 1998, p. 183.

${ }^{41}$ Habermas, J. Faktizität und Geltung, op. cit., p. 12.
} 
entre ambos os conceitos de 'democracia' e 'socialismo', aquele de democracia se tornou o conceito chave - ou tem de se tornar. Eu acredito que esse constitui o núcleo positivo que a esquerda deve extrair da bancarrota do "socialismo real"",42.

Acreditamos que a bancarrota do socialismo de Estado e os novos movimentos sociais ocorridos no leste europeu foram sintomáticos para se repensar não apenas os significados históricos, os limites dos estímulos teóricos e orientações normativas da esquerda, mas principalmente para se resgatar mais uma vez o projeto de uma democracia radical. Certamente a esquerda não-comunista - que não se culpou pela falência de um socialismo de Estado que ela sempre criticou - não deveria "agir como se nada tivesse acontecido" "43. As mudanças revolucionárias na União Soviética, Polônia, Hungria, etc., e principalmente no caso da unificação na Alemanha, foram seguidas por um caminho que visava recuperar desenvolvimentos perdidos: a vinculação político-social com as formas de relação e vida do capitalismo desenvolvido e com a tradição político-institucional das revoluções civis burguesas, vinculação que Habermas chamou de "revolução recuperadora", pois apontava para a consolidação de uma sociedade de bem-estar e de constituição democrática. Contudo, esse retorno ao Estado democrático de direito foi acompanhado também de uma tendência de transformação radicalmente democrática da relação entre Estado e sociedade, uma vez que foi fruto de movimentos e críticas profundas às intervenções políticas do Estado ${ }^{44}$. Conseqüência já das crises pós-guerra características do capitalismo de Estado e dos efeitos colaterais da maciça intervenção administrativa, essa revolução recuperadora apontaria para a ampliação de espaços democráticos por trás das linhas do planejamento administrativo do Estado social. Os novos movimentos sociais, que respondiam às desastrosas conseqüências do estatismo social sobre diferentes formas de vida, formas de participação, solidariedade e autonomia, pretendiam tornar o Estado social mais reflexivo ao constituírem demandas pela conquista de direitos e garantias individuais, passando pela rediscussão de problemas de redistribuição econômica e compensações sociais, até reivindicações por reconhecimentos de identidades coletivas marginalizadas, etc. Tais acontecimentos indicariam a possibilidade de superação da antinomia clássica entre reforma ou revolução, pois acirravam a relação entre democracia

\footnotetext{
${ }^{42}$ Wellmer, A. "Bedeutet das Ende des 'realen Sozialismus' auch das Ende des Marxschen Humanismus?". In: Endspiele: Die unversöhnliche Moderne. Frankfurt7M: Suhrkamp, 1993, p. 91; cf. também, Negt, O. Keine Demokratie ohne Sozialismus. Über den Zusammenhang von Politik, Geschichte und Moral. Frankfurt/M: Suhrkamp, 1976.

${ }^{43}$ Habermas, J. "Die nachholende Revolution und linker Revisionsbedarf: Was heißt Sozialismus heute?", op. cit., p. 188.

${ }^{44} \mathrm{O}$ Estado não mais poderia assegurar por meios administrativos o "sentimento de revolta que se expressava na forma da soberania popular radicalmente democrática”. Webbeler, N. Die Gründung der Solidarnosc - Beginn der Demokratisierungsbewegung in Polen: Hintergründe und Rahmenbedingungen. GRIN, 2005, p. 14. Cf, também Weber, W. Solidarnosc 1980-81 und die Perspektiven der politischen Revolution. Arbeiterpresse, 1987.
} 
radical e Estado de direito e lançavam nova luz à pluralidade de sentidos que a esquerda atribuiria hoje aos seus ideais emancipatórios ${ }^{45}$.

Seria um equívoco considerar a tentativa de reconstrução de uma democracia radical a partir de tais acontecimentos como mero otimismo diante de um possível resgate dos princípios democráticos ${ }^{46}$. Na verdade, seria necessário um ceticismo suficientemente forte para não se exaltar acriticamente tais princípios democráticos. A avaliação cética da situação mundial atual, como já disse Habermas, forma o pano de fundo de nossa reflexão sobra a democracia ${ }^{47}$. Primeiramente porque "quem venceu a concorrência sistêmica contra o socialismo de Estado não foi o capitalismo, mas sim um capitalismo domesticado pelo Estado social dentro das constelações favoráveis do período pós-guerra; mas tal capitalismo se encontra hoje em vias de dissolução" ${ }^{\text {"48 }}$. Além disso, a atitude burocrática do Estado já vinha sendo explorada pelos neo-conservadores, os quais tomam um outro rumo. Eles pretendem "vender a bem conhecida política do deslocamento dos problemas do Estado para o mercado, sob o manto das palavras de ordem 'liberdade e democracia' - uma política que, sabe Deus, nada tem a ver com democratização, que, ao contrário, promove uma crescente desvinculação da atividade do Estado da pressão legitimadora da esfera pública, e que entende por liberdade não a autonomia do mundo da vida, mas a liberdade de ação dos investidores privados"49. As transformações no leste europeu também mostraram que não existe um nexo automático entre modernização capitalista e democracia, entre crescimento econômico e liberdade política. "O resto da utopia que eu consegui manter", ainda segundo Habermas, "é simplesmente a idéia de que a democracia - e a disputa livre por suas melhores formas - é capaz de cortar o nó

\footnotetext{
${ }^{45}$ Cf. Arato, A./Cohen, J. Civil society and political theory. MIT, 1995, sobretudo a introdução.

${ }^{46}$ Tal como ocorreu no caso de Habermas. O autor ficou marcado por ter aceitado alguns traços da democracia liberal que foi negada pelos seus antecessores diretos do marxismo ocidental. Algumas considerações biográficas mostram que isso foi possível por se formar em uma Alemanha pós-totalitária e suspeitar do processo de democratização (ou de reeducação alemã) menos do que a geração anterior, a qual manteve em suas memórias um experimento democrático que tinha falhado. O próprio Habermas se diz "um produto da 'reeducação', e, espero, um produto não tão negativo. Com isso eu quero dizer que nós aprendemos durante esse período que o Estado constitucional, em sua forma francesa, americana ou inglesa, é uma conquista histórica. Essa é uma diferença biográfica importante entre aqueles que viveram aquilo para onde uma entusiasmada república burguesa, como a república de Weimar, pode levar, e aqueles que formaram sua consciência política depois disso". Habermas, J. "Interview mit Deflet Horster und Willen van Reijen". In: Habermas, J. Kleine politische Schriften I-V. Frankfurt/M: Suhrkamp, 1981, p. 513-514. Cf. Adamson, W. "Beyond 'Reform or Revolution': Notes on political education in Gramsci, Habermas and Arendt”. In: Theory and society, 6, 3, 1978. Ver também Jay, M. Marxism and totality. Berkeley: University of Califórnia Press, 1984, p. 466. Ver ainda Tomber, F. Habermas und der Marxismus, op. cit., primeiro capítulo; e Wigerhaus, R. Die Frankfurter Schule. München: dtv, 1988, p. 597 e ss.

${ }^{47}$ Cf. Habermas, J. "Ein Gespräch über Fragen der politischen Theorie”. In: Habermas, J. Die Normalität einer Berliner Republik. Frankfurt/M: Suhrkamp, 1995, p. 136.

${ }^{48}$ Idem, p. 162.

${ }^{49}$ Habermas, J. "Ein Interview mit der New Left Review". In: Habermas, J. Die Neue Unübersichtlichkeit. Frankfurt/M: Suhrkamp, 1985, p. 248-249.
} 
górdio dos problemas simplesmente insolúveis. Eu não pretendo que iremos ser bemsucedidos nesse empreendimento. Nós nem ao menos sabemos se é dada a possibilidade desse sucesso. Porém, pelo fato de não sabermos nada a esse respeito, devemos ao menos tentar. Sentimentos apocalípticos não produzem nada, além de consumir as energias que alimentam nossas iniciativas. O otimismo e pessimismo não são as categorias apropriadas a esse contexto" ${ }^{50}$. Pois as atuais sociedades ocidentais correm o risco de que a política perca sua autocompreensão e orientação (uma vez que "as instituições existentes da liberdade não são mais inatacáveis" ${ }^{51}$ ), causando uma "inquietação" cujo motivo é o de que "não se pode ter nem manter um Estado de direito sem democracia radical" ${ }^{, 52}$. Essa inquietação exige saber se uma democracia radical é possível nas condições atuais de uma sociedade capitalista.

Por fim, a tentativa de pensar a revisão da esquerda - sempre assumindo que a questão aponta, na sua gênese e resultado, para além de qualquer autor em particular - , embora limite o campo de argumentação a seus contextos sempre específicos e aos quais este trabalho propôs se restringir, não poderia deixar de ter em vista a questão da relação entre socialismo e democracia, ou marxismo e democracia, tal como se desenrolara há muito no Brasil. Muitos autores enfrentaram, partindo de tradições e assumindo posições bem variadas, os desafios de se pensar sob quais condições a emancipação poderia se realizar em um capitalismo periférico $^{53}$. Receiamos apenas que nossas particularidades sociais e políticas não impediram que, em linhas gerais, a antinomia revolução versus reforma também no Brasil acabasse por se constituir em "idéia fora do lugar" ${ }^{24}$. É bem verdade que a situação presente - seja em função das circunstâncias internacionais após 1989, seja devido à "nova intransparência" que marcou o horizonte nacional de muitos a partir de 2003 - favoreceu a necessidade de autoreflexão da esquerda brasileira, mas não evitou que os diagnósticos mais uma vez

\footnotetext{
${ }^{50}$ Habermas, J. Vergangenheit als Zukunft. München: Piper, 1993, p. 94. Mais recentemente, ver também Habermas, J. Ach, Europa. Frankfurt/M: Suhrkamp, 2008.

${ }^{51}$ Habermas, J. Faktizität und Geltung, op. cit., p. 13.

${ }^{52}$ Ibidem.

${ }^{53}$ Para uma visão de conjunto, ver os seis volumes sobre História do marxismo no Brasil. Campinas: Editora Unicamp, 2007 (os respectivos organizadores de cada volume se encontram citados na bibliografia). Ver ainda o debate Oliveira, F. et alt. "Adeus ao socialismo". Novos Estudos Cebrap, 30, 1991. Acreditamos que nossa tentativa de pensar o conceito de emancipação a partir da relação entre democracia e socialismo se assemelha ao ponto de partida das formulações que Carlos Nelson Coutinho forneceu a partir de seus estudos sobre Gramsci, ainda que tal semelhança se deva mais ao "espírito" do que à "letra", como teremos oportunidade de discutir em nosso último capítulo Cf. Coutinho, C. N. A democracia como valor universal. Salamandra, 1984; e também Gramsci:Um estudo sobre seu pensamento político. Rio de Janeiro: Civilização Brasileira, 2007.

${ }^{54}$ Fazendo alusão a Schwarz, R. "As idéias fora do lugar”. In: Schwarz, R. Ao vencedor as batatas. São Paulo: Editora 34, 2001.
} 
colidissem e repusessem a clássica antinomia socialista ${ }^{55}$. Entre os mais paradigmáticos, Paulo Arantes comenta em entrevista que "a idéia de utopia, de uma saída possível, está se tornando socialmente proibitiva. E o socialismo também. A idéia clássica de socialismo tem de ser inteiramente repensada" ${ }^{\circ 6}$. Mas apenas em termos de tudo ou nada, de socialismo ou barbárie, de modo que hoje "quem fala em socialismo parece ter ficado para trás" ${ }^{\text {57 }}$. E Ruy Fausto enfrenta a ambiguidade do socialismo democrático propondo "injetar democracia nos movimentos sociais em geral essencialmente 'negativos' e sujeitos a tentações quasetotalitárias; e desenvolver um espírito radical democrático nos socialistas e verdes" ${ }^{\text {"58 }}$, isto é, uma reforma radical no e do interior dos partidos.

Pretendemos mostrar neste trabalho que, diante da antinomia que também aqui insiste em ser preservada, emancipação significaria "libertação de energias políticas paralizadas",59, o que já nos levaria a adotar caminhos diferentes dos sugeridos acima, sem sentimentos apocalípticos ou receios diante dos movimentos sociais ${ }^{60}$. O esgotamento da utopia em face dos obstáculos da economia e do poder político pôs de lado não a orientação emancipatória socialista, mas suas determinações totalizantes. A utopia da sociedade do trabalho parece ter ficado para trás, mas não o ímpeto de formas de vida que reagem e lutam pelo seu espaço de autonomia, mostrando que a emancipação não tem apenas $u m$ sentido, mas é perpassada por uma pluralidade de perspectivas. E as manifestações de revolta não são inventadas pelo teórico. Elas ou são provocadas estruturalmente pelas desigualdades produzidas pelo mercado e pelo Estado ou pela dinâmica dos conflitos em torno de valores, do pluralismo social e cultural, dos fenômenos de intolerância, injustiça, etc. Além disso, do mesmo modo que a liberdade e a igualdade encontram sua formulação no interior desses conflitos, uma vez que

\footnotetext{
${ }^{55}$ Como tivemos a oportunidade de tratar em resenha do livro de Ruy Fausto em Melo, R. "A esquerda difícil: Em torno do paradigma e do destino das revoluções do século XX e alguns outros temas de Ruy Fausto". In: Cadernos de filosofia alemã, 11, 2008, p. 141-151.

${ }^{56}$ Arantes, P. "Entrevista”. In: Nobre, M./Rego, J. M. Conversas com filósofos brasileiros. São Paulo: Editora 34, 2000, p. 368.

${ }^{57}$ Ibidem.

${ }^{58}$ Fausto, R. A esquerda difícil: Em torno do paradigma e do destino das revoluções do século XX e alguns outros temas. São Paulo: Perspectiva, 2007, p. 239.

${ }^{59}$ Habermas, J. “Interview mit Hans Peter Krüger”, op. cit., p 93.

60 Também nos distanciamos de propostas como as desenvolvidas por Fernando Haddad em Trabalho $e$ linguagem: Para a renovação do socialismo. Rio de Janeiro: Azougue, 2004. Entendemos que o autor não tira todas as conseqüências dos diagnósticos de que parte (a não confirmação de uma teoria do colapso capitalista, a crise da sociedade do trabalho, a recomposição orgânica da classe trabalhadora e a crise do Estado de bem-estar social). Vinculando trabalho e linguagem, Haddad continua insistindo, porém, em retomar a trilha de uma emancipação dos trabalhadores, por meio de cooperação, etc. (Idem, p. 158) e não se debruça de fato na descrição do potencial dos "processos de formação da vontade na esfera pública" (Idem, p. 58), os quais deveriam ter voltado sua atenção a fenômenos diferentes da luta social e de processos de democratização. Além disso, é preciso levar em conta que tais diagnósticos não se aplicam sem mais ao caso brasileiro, de modo que o problema grave da desigualdade social requer, inevitavelmente, soluções redistributivas.
} 
precisam ser constantemente negociadas pelos próprios concernidos para que possam se realizar efetivamente como tal, também a própria esquerda precisa ser um termo em disputa ${ }^{61}$. E a negociação e a disputa, imprescindíveis para os sentidos da emancipação, não podem ser mantidas sem democracia radical.

Os três capítulos seguintes foram organizados em duas partes com o intuito de marcar a distinção entre uma crítica ao paradigma produtivista e uma reconstrução do conceito de emancipação não mais fundado no modelo de ação baseado no trabalho. Como proposto, as orientações revolucionárias e reformistas levaram adiante o projeto de uma democracia radical apenas parcialmente, reduzindo a autonomia - assumida aqui como fio condutor da autocompreensão política de sociedades modernas - no processo de realização da utopia de uma sociedade do trabalho. Por essa razão, a exposição do primeiro capítulo pretendeu sublinhar inicialmente a compreensão funcionalista da democracia que resultaria das críticas de Marx à sociedade civil. Tais críticas pressupõem que a restituição da autonomia alienada sob condições capitalistas dependeria antes da transformação do trabalho heterônomo em trabalho autônomo, justificando assim tanto as bases do argumento ortodoxo, segundo o qual a emancipação decorreria apenas das determinações estruturais do desenvolvimento capitalista, como a substituição da constituição de uma comunidade de livres e iguais pela auto-organização holista de trabalhadores associados, libertos do fetiche do capital. Além disso, o próprio conceito de práxis política, central para a idéia de uma autoemancipação do proletariado, seria concebido no processo revolucionário como epifenômeno das relações econômicas, limitando a atividade autônoma da classe trabalhadora à autoatividade produtiva assim como fundindo e homogeneizando a autodeterminação política, de sorte que o proletariado fosse constituído somente como uma afirmação subjetiva da lógica reprodutiva do próprio capital.

A orientação reformista, por sua vez, abdicou do socialismo científico e das pretensões revolucionárias estabelecendo seu programa político com base em refomas políticoadministrativas centralizadas na universalização dos direitos civis. No segundo capítulo pretendemos caracterizar os dois pilares desse programa distinguindo analiticamente a pretensão de realização da justiça social e da humanização do trabalho, de um lado, da tentativa de domesticação do capitalismo por meio de intervenção estatal, de outro lado. $\mathrm{O}$ núcleo normativo do reformismo social-democrata consistia, portanto, na transformação do trabalho considerado mercadoria em trabalho entendido como base de um direito de cidadania

\footnotetext{
${ }^{61}$ Cf. Nobre, M. "Novas polarizações - ainda sobre esquerda e direita”. In: Econômica. Rio de Janeiro, v. 9, n. 2, 2007, p. 341-351.
} 
industrial. Contudo, as conquistas obtidas pelo Estado social confinavam paradoxalmente a democracia à instância meramente administrativa que determinava o plano social-democrata, engessando a autodeterminação política dos cidadãos no papel de mero cliente da burocracia dos programas de bem-estar e no de consumidor de bens de massa. Por conseguinte, a crise de legitimação gerada pela redução da autonomia ao mero poder administrativo foi diagnosticada em função da produção de novas formas de reificação, de colonização e juridificação das formas de vida. A única possibilidade de continuar o projeto de universalização dos direitos civis e de ampliação da cidadania consistia na afirmação do poder de integração da solidariedade em face do valor de troca e do poder administrativo, ou seja, da revitalização da autodeterminação política abandonada pelo reformismo social-democrata.

A retomada do sentido normativo da autonomia, que conduziu os movimentos de libertação da era das revoluções democráticas, consiste no ponto de partida do terceiro e último capítulo. Na verdade, apenas nesse momento da exposição será possível explicitar a perspectiva que perpassava implicitamente a análise dos dois primeiros capítulos, a saber, a emergência de uma pluralidade de movimentos sociais, mobilizações políticas e manifestações de revolta que permitem que os diversos sentidos da emancipação sejam articulados com o projeto de uma democracia radical. Essa cultura política, formada por um público capaz de se mobilizar diante dos riscos da perda de liberdade, torna presente o ideal de um Estado democrático de direito na medida em que o vincula necessariamente aos processos políticos de legitimação, de modo que o projeto político moderno seja articulado com as lutas sociais e com uma concepção de democracia sensível às manifestações da esfera pública. Porém, uma vez que os movimentos por emancipação não podem mais ser explicados a partir do conceito de totalidade, pretendemos mostrar que a autodeterminação política é conquistada apenas no interior de um processo de circulação do poder em que se luta pela integridade das formas de vida, pelos espaços de autorealização e conquistas de direitos em face da pressão exercida pelos imperativos da economia e as constrições do sistema político. Desse modo, percebemos que a afirmação radical da autodeterminação política não visa à substituição ou supressão completa do Estado, mas reforça seus espaços de liberdade e autonomia também por meio dele, exigindo direitos políticos, sociais e culturais, bem como maior participação nos processos de formação política da opinião e da vontade e nos procedimentos democráticos de deliberação pública. Por fim, a pluralidade dos movimentos por emancipação em torno da reivindicação de direitos legítimos será considerada a partir das lutas por reconhecimento, em que se explicita a interdependência e as relações recíprocas entre política e direito. 
Parte I

A utopia da sociedade do trabalho:

Crítica ao paradigma produtivista de emancipação 


\section{Capítulo 1}

\section{Emancipação e revolução}

As análises sobre a orientação revolucionária de emancipação consistem no primeiro passo das críticas a todo o âmbito daquilo que muitos autores entenderam na obra de Marx também por paradigma produtivista ${ }^{1}$. Sabemos que a cisão no interior do socialismo logo após a Segunda Internacional consolidou a distinção entre o socialismo democrático e o comunismo revolucionário - distinção que se referia a oposições presentes no interior do próprio marxismo ${ }^{2}$. Apesar das especificidades de cada um dos partidos, tanto os reformistas quanto os comunistas reivindicavam o nome de Marx para fundamentar suas estratégias políticas e orientações teóricas em torno do problema colocado por tal paradigma, em linhas gerais passando a reagir contra o economicismo e o objetivismo histórico da Segunda Internacional - embora, como vermos, repondo-o. Mais precisamente, as críticas abordadas no presente capítulo dirigem-se aos pressupostos teóricos do paradigma produtivista que alimentaram o chamado marxismo ortodoxo ${ }^{3}$, cuja interpretação dos textos de Marx estreitaria justamente os laços entre a lógica reprodutiva do capital e as condições revolucionárias de emancipação. Considerando-se a história dos efeitos, contudo, o desdobramento dessas críticas atingiria não apenas a corrente revolucionária do marxismo soviético ${ }^{4}$, mas inclusive teóricos do marxismo ocidental ${ }^{5}$, uma vez que tratar-se-ia de considerar em ambos os casos os limites da compreensão funcionalista da democracia e os déficits normativos da crítica social ${ }^{6}$.

\footnotetext{
1 Para uma caracterização inicial do paradigma produtivista em Marx, remetemos principalmente para Baudrillard, J. Le miroir de la production. Ou, l'illusion critique du matérialisme historique. Paris: Galilée, 1985; Rundell, J. Origins of modernity: The origins of modern social theory from Kant to Hegel to Marx, op. cit., capítulo 5; e Márkus, G. "Die Welt meschlicher Objekte. Zum Problem der Konstitution im Marxismus". In: Honneth, A./Jaeggi, U. (org). Arbeit, Handlung, Normativität, op. cit., p. 12- 136.

${ }^{2}$ Cf. Reisberg, A. Von der I. zur II. Internationale. Die Durchsetzung des Marxismus um die Wiederherstelung der Arbeiterinternationale. Dietz, 1980; eVranicki, P. Geschichte des Marxismus. 2 Bände. Frankfurt/M: Suhrkamp, 1997.

${ }^{3}$ Para uma exposição dos principais traços do marxismo ortodoxo, ver Postone, M. Time, labor and social domination. A reinterpretation of Marx's critical theory. Cambridge University Press, 1993, capítulo 1.

${ }^{4}$ Sobre o marxismo soviético, ver Marcuse, H. Die Gesellschaftslehre des sowjetischen Marxismus. Schrifften. Band 6. Frankfurt/M: Suhrkamp, 1989.

${ }^{5}$ A tradição do marxismo ocidental inclue Georg Lukács, Gramsci e também representantes da teoria crítica, dentre os quais Herbert Marcuse, Max Horkheimer e Theodor Adorno. Destes, somente Lukács e Marcuse mantiveram uma orientação revolucionária, embora o segundo procurasse superar também o paradigma produtivista do marxismo. Sobre o marxismo ocidental, ver principalmente Jay, M. Marxism and totality, op. cit.; e também Merleau-Ponty, M. As aventuras da dialética. São Paulo: Martins Fontes, 2006; e também Anderson, P. Considerações sobre o marxismo ocidental. São Paulo: Boitempo, 2004.

${ }^{6}$ Provavelmente tal crítica não atingisse a Franz Neumann. Cf. Neumann, F. The rule of law. Political theory and the legal system in modern society. Leamington: Berg, 1986.
} 
Não se trata apenas de admitir a crise de pressupostos da teoria revolucionária como fizeram marxistas não-ortodoxos a partir das experiências do facismo, do stalinismo ou do New Deal ${ }^{7}$. Para resgatar com Marx as críticas à dominação, injustiça e desigualdade impostas sobre a sociedade em razão da racionalização capitalista e pretender apontar para alternativas emancipatórias reais, seria preciso reconstruir e criticar os pressupostos que se encontrariam na base da própria teoria marxista. Mais especificamente, os conceitos determinados pelo esquema geral da produção "não serviriam mais como ponto de partida para unificar, teorica e praticamente, a pluralidade de lutas e movimentos sociais na sociedade contemporânea"8. Embora para alguns autores o paradigma produtivista ainda fosse essencial para a elaboração de uma crítica social renovada ${ }^{9}$, a tentativa de superação de um "estreitamento economista do marxismo"10 e de seu respectivo "modelo de ação baseado no trabalho" $" 11$ parece ser um ponto decisivo para se levar adiante os interesses emancipatórios que Marx desde sempre perseguiu. Pois tal paradigma seria responsável por encobrir o núcleo normativo de autodeterminação política que os próprios defensores da revolução teriam herdado dos movimentos burgueses por emancipação: com o abandono do princípio de uma democracia radical, congelar-se-ia a possibilidade de se pensar atualmente tanto uma radicalização de formas de vida que pretendem negociar autonomamente as condições da liberdade e da igualdade, bem como as novas formas de luta política em sociedades democráticas, complexas e pluralistas.

O paradigma produtivista estaria intimamente ligado às formulações mais fundamentais da orientação revolucionária por emancipação ao menos em três grandes momentos, que poderiam ser esquematicamente apresentados do seguinte modo. Primeiramente, a perspectiva privilegiada da crítica da economia política demarcaria o objeto da análise do desenvolvimento das sociedades modernas como sociedade do trabalho estabelecida em termos de economia de mercado, de atividade produtiva e de relações de produção. Em segundo lugar, a teoria de Marx não estaria limitada à crítica da sociedade

\footnotetext{
${ }^{7}$ Cf. Habermas, J. "Zwischen Philosophie und Wissenschaft: Marxismus als Kritik". In: Habermas, J. Theorie und Praxis. Frankfurt/M: Suhrkamp, 1993, p. 228 e ss.

${ }^{8}$ Cohen, J. Class and civil society: The limits of marxian critical theory, op. cit., p. xii.

${ }^{9}$ Cf. Postone, M. Time, labor and social domination. A reinterpretation of Marx's critical theory, op. cit.

${ }^{10}$ Honneth, A. Luta por reconhecimento: A gramática moral dos conflitos sociais. Trad. Luiz Repa. São Paulo: Ed. 34, 2003, p. 229. Cf. ainda Honneth, A. “Arbeit und instrumentales Handel”, op. cit., p. 185-233. Tais críticas serão centrais também na sua reatualização do conceito lukacsiano de reificação em Verdinglichung: Eine anerkennungstheoretische Studie. Frankfurt/M: Suhrkamp, 2005.

${ }^{11}$ A superação desse "modelo de ação baseado no trabalho" seria central para a tarefa de uma fundamentação normativa da teoria crítica. Essa reconstrução da teoria de Marx e suas implicações para a crítica social contemporânea encontram-se muito bem analisadas em Cohen, J. Class and civil society: The limits of marxian critical theory, op. cit.; e Benhabib, S. Critique, norm and utopia. New York: Columbia University Press, 1986.
} 
capitalista, mas visava à sua superação prática. Para que pudesse fundamentar o interesse emancipatório em condições revolucionárias imanentes, tal superação se encontraria objetivamente determinada pelo desenvolvimento das forças produtivas, fazendo com que paradoxalmente o progresso capitalista consistisse na única via - ou na via principal - de sua própria dissolução. Por fim, embora não haja uma caracterização sistemática, a imagem de sociedade emancipada teria sido pensada como auto-organização livre dos trabalhadores nas comunidades de produção. Os revolucionários em geral estabeleceram como fim último uma sociedade próspera, altamente produtiva, capaz de preencher o "reino das necessidades" de todos os indivíduos por igual e, em decorrência disso, acreditavam assegurar também o "reino da liberdade": uma vez desfeita a aparência do capital, restitui-se a espontaneidade antes reificada às relações da vida. É verdade que alguns pressupostos decisivos do paradigma produtivista, presentes nesse movimento objetivo da história, precisariam ser estabelecidos em termos de uma filosofia da práxis. Todo esse processo do trabalho seria representado como um processo cíclico de exteriorização, objetivação e apropriação ${ }^{12}$. Nesse processo, a práxis social articularia a natureza subjetiva dos indivíduos tanto com a natureza exterior objetivada como com o mundo circundante. "Por conseguinte", comenta Habermas, "o processo de automediação da natureza concentra em si a autorealização dos sujeitos ativos que nela atuam. Ambos são processos de autoprodução; eles se produzem a partir de seus próprios produtos" ${ }^{\prime 13}$. Desse modo, a sociedade resultante dessa práxis seria concebida como produto das forças produtivas e das relações de produção criadas em e por meio dela.

A dificuldade concernente aos pressupostos economicistas da abordagem revolucionária como chave de orientação emancipatória resultaria primeiramente de sua dissolução sociológica de elementos normativos que marcaria as considerações subseqüentes da crítica social marxista, de sua avaliação da democracia e da tradição do direito natural racional ${ }^{14}$. Por manter o campo de análise dos fenômenos políticos e sociais preso ao horizonte da utopia de uma sociedade do trabalho, "Marx não poderia formular sua concepção de sociedade pós-capitalista em termos de uma soberania ou autonomia multidimensional que incluísse a dimensão das normas éticas e das instituições que as estruturam. Isso ocorre não somente por causa do desdém pela política (e particularmente por sua forma burguesa) que se integrava no seu paradigma da produção, mas principalmente em razão da prioridade atribuída

\footnotetext{
${ }^{12}$ Cf. Lange, E. M. Das Prinzip Arbeit. Frankfurt/M: Ullstein, 1980, capítulos 1 e 2.

${ }^{13}$ Habermas, J. Der Philosophische Diskurs der Moderne, op. cit., p. 396.

${ }^{14}$ Cf. Habermas, J. "Naturrecht und Revolution". In: Habermas, J. Theorie und Praxis. Frankfurt/M: Suhrkamp, 1963, p. 117; ver também Habermas, J. Faktizität und Geltung, op. cit., p. 62-77.
} 
ao desenvolvimento das forças produtivas como um impulso emancipatório"15. Por conseguinte, boa parte da força que essa crítica social dedicou à denúncia de seu próprio contexto se revelaria um ponto de partida restritivo, pois "Marx e seus seguidores permaneceram presos (...) ao contexto de nascimento e ao formato reduzido do primeiro industrialismo"16. A investigação de um sistema de produção e reprodução dos valores de troca assumiria uma centralidade tão definitiva que resultaria em um déficit de maior consequiências práticas para as orientações da esquerda socialista, a saber, "uma limitada compreensão funcionalista do Estado democrático de direito, que Marx viu efetivado na Terceira República, e que desdenhosamente rejeitou como 'democracia vulgar",17.

Veremos que a análise da lógica de produção e reprodução material capitalista ganharia uma dimensão radical no desenvolvimento da crítica da economia política elaborada por Marx, dissolvendo sociologicamente os princípios normativos e instituições inerentes às estruturas políticas modernas e determinando-os essencialmente de acordo com o modelo da base/superestrutura. O resultado dessa dissolução consistiria em uma consideração meramente funcionalista da democracia e na sua substituição por um modelo de integração social baseado na auto-organização dos trabalhadores. Nesse caso, o modelo de sociedade justa e igual seria pensado por Marx segundo uma concepção holista na qual o desenvolvimento das forças produtivas forneceria a base para a reunificação da autoatividade com o trabalho, do controle autônomo dos "produtores associados" sobre as próprias condições materiais da vida (I). Mas além disso, o paradigma produtivista não apenas serviria para a crítica da sociedade civil, mas delimitaria o próprio conceito do político em sua teoria da revolução a ponto de reduzi-lo a epifenômeno das relações econômicas. O problema principal consistiria em que, nessa delimitação, a ampliação do conceito do político para o campo da emancipação social permaneceria presa a um estreito conceito de práxis, pois o potencial emancipatório permaneceria subordinado às noções de trabalho, de desenvolvimento das forças produtivas e, conseqüentemente, à própria teoria das classes. Nessa perspectiva, “caberia a priori um papel inquestionavelmente emancipatório ao trabalho e ao desenvolvimento das forças produtivas. As formas de organização que se desenvolvem com a concentração das forças de trabalho nas fábricas devem ao mesmo tempo constituir a infra-estrutura para os laços de solidariedade, para a conscientização e a atividade revolucionária daqueles que produzem. Com essa

\footnotetext{
${ }^{15}$ Rundell, J. Origins of modernity: The origins of modern social theory from Kant to Hegel to Marx, op. cit., p. 121.

${ }^{16}$ Habermas, J. "Die nachholende Revolution und linker Revisionsbedarf: Was heißt Sozialismus heute?", op. cit., p. 189.

${ }^{17}$ Idem, p. 190.
} 
abordagem produtivista, porém, a visão é de certo modo desviada das ambivalências da progressiva dominação da natureza, bem como das forças de integração social aquém e além da esfera do trabalho social" "18 . A dimensão política seria reconstruída, pelo contrário, por um conceito ampliado de práxis baseado também na interação que libertasse o potencial emancipatório presente na dinâmica existente dos conflitos políticos das determinações economicistas do modelo de ação autônoma baseado no trabalho (II).

\section{I - Autovalorização do capital: Dissolução sociológica do direito e da democracia}

1. Base econômica e superestrutura política:

A anatomia da sociedade civil em Marx

No conhecido Prefácio de sua Contribuição à crítica da economia política, Marx afirmou o seguinte: "Na produção social de sua existência, os homens inevitavelmente entram em determinadas relações que são independentes de sua vontade, a saber, as relações de produção apropriadas em um dado estágio do desenvolvimento de suas forças materiais de produção" ${ }^{19}$. Seria principalmente enquanto crítico da economia política que Marx teria reconhecido a verdadeira anatomia da sociedade civil. Com aquela, fora possível descrever não apenas como as estruturas fundamentais da sociedade moderna estariam apoiadas no processo de autovalorização do capital, mas também revelar que tal processo cada vez mais se distanciaria da atividade autônoma dos indivíduos: "De um conjunto de condições que autorizam e possibilitam a liberdade, sob as quais os indivíduos podem se associar com vontade e consciência e submeter o processo social a seu controle comum, a sociedade civil se transforma em um sistema que domina anonimamente e que se autonomiza diante das intenções dos indivíduos socializados inconscientemente, obedecendo à própria lógica e submetendo a sociedade em seu todo aos imperativos econômicos de sua autoestabilização"20. Mais especificamente, Marx descobriu em sua investigação que "as relações jurídicas e as formas do Estado (...) encontrariam suas raízes nas condições materiais da vida (...)

\footnotetext{
${ }^{18}$ Idem, p. 189.

${ }^{19}$ Marx, K. Zur Kritik der Politischen Ökonomie. In: Marx-Engels Werke, Band 13. Berlin: Dietz Verlag, 1961, p. 8. (Grifo nosso)

${ }^{20}$ Ibidem.
} 
combinadas sobre o nome de 'sociedade civil'; a anatomia da sociedade civil deve ser observada na economia política" ${ }^{21}$.

Para entender a extensão da crítica de Marx, essa anatomia da sociedade civil seria compreendida como contendo um efeito desmascarador diante das concepções que compunham os princípios burgueses modernos de organização social. Seguindo a sugestão de Georg Lohmann e Jean Cohen, é necessário considerar inicialmente duas teses programáticas presentes na crítica da economia política: em primeiro lugar, teríamos de entender o empreendimento de Marx a partir de uma "crítica imanente" da sociedade civil concebida segundo representações do direito natural (ou direito racional); em segundo lugar, essa crítica imanente seria desenvolvida de acordo com uma "crítica transcendente" ou "crítica desmascaradora" do espaço categorial desses princípios ${ }^{22}$. Trata-se, em outros termos, de sublinhar que a vida social não se reproduz mais por meio de mecanismos normativos de integração social, tais como aqueles presentes na tradição do direito racional. Um novo modelo pretensamente mais realista de uma socialização anônima não-intencional, capaz de se impor por trás das costas dos indivíduos, substituiria o modelo idealista de uma associação intencionalmente produzida e continuadamente mantida de parceiros do direito que caracterizava a sociedade civil desde Locke ${ }^{23}$.

Essa substituição ocorreria devido às categorias fornecidas, em um primeiro momento, pela economia política clássica. Adam Smith e Ricardo formularam uma análise da sociedade civil interpretando-a não mais com base nas categorias do direito racional, mas sim como uma esfera de comércio e de trabalho social que seria dominada por leis autônomas. Se o direito racional fornecia o modelo normativo de construção de uma organização política, a economia política descrevia a sociedade civil antes com base nas relações de trabalho social organizado pela economia de mercado: substitui-se assim os processos de socialização representados na forma de um contrato social estabelecido entre pessoas consideradas livres e iguais por um "sistema de relações de apropriação de bens (mercadorias), a qual acontece com base na troca

\footnotetext{
${ }^{21}$ Marx, K. Zur Kritik der Politischen Ökonomie, op. cit., p. 8.

${ }^{22}$ Cf. Lohmann, G. "Gesellschaftskritik und normativer Maßtab. Überlegungen zu Marx". In: Honneth, A./Jaeggi, U. (org). Arbeit, Handlung, Normativität, op. cit., p. 237 e ss. Cf. Cohen, J. Class and civil society: The limits of marxian critical theory, op. cit., p. 36 e ss. Também Cohen admite tais teses programáticas, embora tire consequiências diferentes da relação entre ambas para o desenvolvimento da crítica imanente no jovem Marx em comparação com suas formulações maduras, como veremos na segunda seção do presente capítulo. Estratégia semelhante é adotada por Wellmer, A. "Naturrecht und praktische Vernunft. Zur aporetischen Entfaltung eines Problems bei Kant, Hegel und Marx". In: Wellmer, A. Endspiele: Die unversöhnliche Moderne, op. cit., p. 95-153; e Rundell, J. Origins of modernity: The origins of modern social theory from Kant to Hegel to Marx. op. cit, capítulos 4 e 5.

${ }^{23}$ Cf. Habermas, J. Faktizität und Geltung, op. cit. p. 65. Em linhas gerais, essa é a tese de Georg Lohmann em seu livro Indiferenz und Gesellschaft. Frankfurt/M: Suhrkamp, 1991. Para a análise e a crítica de um funcionalismo economicista do direito, ver especialmente capítulo 6.
} 
ou em razão do próprio trabalho despendido na produção" ${ }^{\text {24 }}$. A sociedade civil encontraria assim sua estabilização ao se integrar segundo princípios não-normativos: juntamente com o sistema jurídico, ela seria constituída por um sistema de necessidades estabelecido com base na produção, uso e troca de mercadorias e organizado pela economia de mercado. Com tal mudança de perspectiva em face da tradição da filosofia política moderna, Marx percebera que "não são mais as relações baseadas no direito, mas sim as relações de produção que formam o esqueleto que mantém coeso o organismo social" 25 .

Certamente Marx havia percebido algo além dessa substituição ao notar que as relações jurídicas encontrariam suas raízes nas bases materiais da vida. Ao caracterizar a sociedade civil segundo as relações de produção, a economia política clássica permitiria simplesmente que se vinculasse as pretensões dos princípios burgueses da liberdade e da igualdade à instituição da propriedade privada, ou seja, harmonizaria meramente a perspectiva normativa do direito racional com o sistema de apropriação de mercadorias institucionalizado pelo direito privado. Cria-se dessa forma uma suposta organização normativa derivada dessa economia de mercado: por serem proprietários nas relações de apropriação de mercadorias, reconhecemos tais indivíduos como pessoas portadoras de direitos, seja atribuindo-os igualdade nesse processo de troca de equivalentes, seja liberdade de perseguirem seus próprios interesses em relação ao bem trocado ou ao seu próprio trabalho empregado na produção ${ }^{26}$. Nesse caso, o modelo do contrato social poderia se apoiar na evidência de que a sociedade moderna estabelecida sobre as relações de troca garantiria a cada pessoa a autonomia e a igualdade por meio da participação nesse intercâmbio meramente econômico. Segundo a interpretação de Cohen, uma dupla relação de igualdade e liberdade estaria envolvida nessa estrutura da economia de mercado: "há igualdade na medida em que cada um troca mercadorias na mesma relação social que o outro e na medida em que as mercadorias que eles trocam contam como equivalentes; há liberdade em duplo sentido, na medida em que está envolvido um intercâmbio voluntário que ocorre sem coerção e o indivíduo considera como primário e dominante seu interesse egoísta. Finalmente, a presença de uma classe de trabalhadores livres, integrada em relações de mercado universalizadas, gera a emergência do momento jurídico da pessoa. O reconhecimento mútuo e a aceitação das relações contratuais,

\footnotetext{
${ }^{24}$ Lohmann, G. “Gesellschaftskritik und normativer Maßtab. Überlegungen zu Marx”, op. cit., p. 245.

${ }^{25}$ Habermas, J. Faktizität und Geltung, op. cit., p. 65.

${ }^{26}$ Cf. Habermas, J. "Naturrecht und Revolution", op. cit., p. 98-100; e Lohmann, G. "Gesellschaftskritik und normativer Maßtab. Überlegungen zu Marx”, op. cit., p. 241-247.
} 
juridicamente asseguradas, pelas quais cada um reconhece o outro como proprietário, constituem cada um como uma pessoa cuja vontade penetra em sua mercadoria" ${ }^{27}$.

Marx não discordaria que a liberdade e a igualdade encontrariam sua base real nessa relação de produção. Porém, diferentemente da economia política clássica, a implicação mais profunda de sua crítica consistiria antes no fato de que sua análise desmistificaria a sociedade civil demonstrando, principalmente, que esta sociedade repousa sobre um sistema de exploração que perpassaria suas principais instituições e atingiria justamente o núcleo de seu princípio de reciprocidade. Pois os aspectos normativos da troca de equivalentes implicava que, na relação de troca, pressupuséssemos um princípio de reciprocidade, ou seja, um momento de igualdade recíproca por parte daqueles que participavam do processo de troca. Contudo, em vez de uma sociedade civil constituída por pequenos produtores de mercadorias, a economia de mercado formou uma sociedade de classes caracterizada pelos que possuem propriedade e controlam a produção e os que, com o seu trabalho, criam a riqueza da sociedade (e a riqueza dos capitalistas), e que na maioria dos casos precisam vender sua força de trabalho para sobreviver ${ }^{28}$. A economia política não havia atentado ao fato de que, embora a instituição do mercado - em que os proprietários privados trocam mercadorias e os que carecem de propriedade empregam sua força de trabalho - ter sido acompanhada pela promessa de justiça da equivalência das relações de troca, o desenvolvimento das sociedades capitalistas se caracterizaria antes tanto pelo processo de imposição dos imperativos de autovalorização do capital sobre contextos de vida diferenciados como pela institucionalização jurídico-política desse processo de interação conflituosa constituído por uma oposição econômica entre classes sociais.

Em primeiro lugar, a brutalidade com que as leis da economia de mercado se impunham sobre a vida das pessoas se mostrava na crescente reestruturação da atividade, primordial para o processo de produção, do trabalho. A produção das mercadorias a serem trocadas no mercado capitalista estava longe de ser compreendida como uma forma de trabalho de tipo artesanal. Enquanto, neste caso, a realização do trabalho estava concentrada na vontade e capacidade do trabalhador, o qual poderia dar forma criativa à sua produção a ponto de ver no produto uma objetivação de suas mais estreitas qualidades, a nova forma capitalista de trabalho destruía os elementos criativos dos sujeitos, decompondo o processo

\footnotetext{
${ }^{27}$ Cohen, J. Class and civil society: The limits of marxian critical theory, op. cit., p. 145.

${ }^{28}$ Esse processo, que resultaria na apropriação da mais valia do trabalho excedente por parte daqueles que possuem somente a força de trabalho como única mercadoria, foi descrito por Marx em diversas passagens. Cf. principalmente Marx, K. Lohn, Preis und Profit. In: Marx-Engels Werke. Band 16. Berlin: Dietz Verlag, 1968, p. 129-134; e Marx, K. Das Kapital. Vol. I. In: Marx-Engels Werke. Band 23. Berlim: Dietz Verlag, 1998, p. 53, 59, 181-185, seção 3 e p. 331-355.
} 
orgânico de objetivação. Em outras palavras, "para o trabalhador na fábrica tais experiências integralizantes estavam totalmente interditadas, porque seu trabalho era heterônomo, despedaçado e destituído de iniciativa" ${ }^{, 29}$. Embora tenha de ser entendida segundo ações concretas, o emprego da força de trabalho foi descrito como uma operação abstrata, ou seja, como um processo de trabalho organizado formalmente sempre sob o ponto de vista da autovalorização do capital. Marx caracterizou tal força de trabalho, apropriada como mercadoria nas relações de troca e que se aliena do contexto de vida dos trabalhadores, de trabalho abstrato: "Essa relação econômica - que se caracteriza por colocar o capitalista e o trabalhador nos extremos de uma relação de produção - se desenvolve da forma mais pura e adequada quanto mais o trabalho perde todas as suas características artesanais; suas habilidades particulares se tornam algo abstrato e indiferente, transformando-se assim em atividade cada vez mais puramente abstrata, puramente mecânica e, por isso, indiferente diante de sua forma específica, embora continue atividade meramente formal, o que significa dizer que a atividade material em geral é indiferente diante de sua forma específica" ${ }^{\text {30 }}$. O trabalho abstrato, portanto, indiferente em relação ao objeto natural ou material de uso, em relação à necessidade que esse objeto satisfaz, é indiferente em relação ao tipo particular de atividade e também ao próprio indivíduo trabalhador e sua situação social. "Essas características de indiferença", comenta Lohmann, "se expressam nas determinações do trabalho que cria valor de troca, o qual foi chamado de 'igual', 'indiferenciado', 'desindividualizado', 'abstrato' e 'universal'; essas determinações são continuadas nas relações de indiferença (...) que concernem ao comportamento dos trabalhadores com os outros e consigo mesmos",31.

Em segundo lugar, ao descrever o processo de acumulação do capital nas formas de um trabalho social que se autonomizou diante da vontade dos próprios envolvidos, a crítica da economia política descreveria simultaneamente um processo de dominação pretensamente legítimo. "A novidade do modo de produção capitalista", explica Marcos Nobre, "está em que a organização da produção - o mercado, o fato de que todos os produtos são produtos 'paraserem-trocados' - fornece ao mesmo tempo a legitimação da dominação. A troca de

\footnotetext{
${ }^{29}$ Honneth, A. "Trabalho e reconhecimento: tentativa de uma redefinição", op. cit., p. 49. (O grifo é nosso).

${ }^{30}$ Marx, K. Das Kapital. Vol. I, op. cit., p. 204; no mesmo volume ver também p. 25 e 584. Para uma explicação do conceito de "trabalho abstrato", ver principalmente Neuendorff, H. Der Begriff des Interesses. Frankfurt/M, 1973, p. 130 e ss. Cf. também Fausto, R. "Abstração real e contradição: sobre o trabalho abstrato e o valor". In: Fausto, R. Marx: Lógica e política. Vol. I. São Paulo: Brasiliense, 1983, p. 89-138. Ver ainda Lukács, G. "Die Verdinglichung und das Bewußtsein des Proletariats". In: Lukács, G. Geschichte und Klassenbewußtsein. Werke, Band 2 (Frühschriften II). Neuwied und Berlin: Luchterhand, 1968; e Nobre, M. Lukács e os limites da reificação. São Paulo: Ed. 34, 2001, capítulo 1.

${ }^{31}$ Lohmann, G. "Gesellschaftskritik und normativer Maßtab”, op. cit., p. 270-272.
} 
equivalentes não é apenas um critério de trocas econômicas, mas também princípio orientador das trocas simbólicas. O que Marx fez foi demonstrar que a troca de equivalentes de fato se realizava - as mercadorias são vendidas pelo seu valor -, mas com uma exceção decisiva: a forma salário. O mercado e seu mecanismo de funcionamento por si sós não são capazes de produzir a legitimação para o fato de que o capitalista se apropria da diferença entre o valor incrustado na mercadoria pela força de trabalho e o valor correspondente ao custo de reprodução dessa mesma força de trabalho"32.

Mas o que seria propriamente característico de sociedades capitalistas, por fim, consistiria no fato de a sociedade civil encobrir essa relação desigual e conflituosa objetivando-a e cristalizando-a como mercado de trabalho, ou seja, como medium juridicamente institucionalizado das relações de troca: "O mecanismo do mercado de trabalho, institucionalizado pelo direito privado, assume funções daquela relação de poder social e de exploração econômica que se encontrava politicamente institucionalizada. A monetarização da força de trabalho se torna assim a base da relação de classes"33. Segundo essa análise da exploração econômica, institucionalizada pelo direito privado, os mecanismos dos processos de acumulação do capital não seriam implementados por regulamentações neutras do poder, como supunha o liberalismo clássico, pois "nas formas de liberdade contratual burguesa constituem-se novas relações de poder, a começar pelas relações entre proprietários e assalariados" ${ }^{34}$. O império do direito e seus princípios de autonomia e igualdade estariam sujeitos antes aos imperativos econômicos constitutivos de uma sociedade em que a dominação social se exerceria na forma juridicamente institucionalizada tanto do poder de disposição privado sobre os meios de produção como da monetarização da força de trabalho.

Marx teria reconhecido, portanto, que a sociedade civil estaria estruturada de modo a produzir formas cada vez mais drásticas de desigualdade social. Sua análise consistiria, por um lado, em mostrar que o processo de acumulação do capital destruiria a vida daqueles produtores que poderiam oferecer apenas sua força de trabalho como única mercadoria para participar do sistema de troca de equivalentes. Ademais, ele denunciaria também o sistema econômico capitalista não somente por se organizar com base na produção de bens como produção de valores de troca, mas por fundar todo seu conjunto de leis e princípios

\footnotetext{
${ }^{32}$ Nobre, M. A Dialética Negativa de Theodor W. Adorno: A ontologia do estado falso, op. cit., p. 35. (O grifo é nosso).

${ }^{33}$ Habermas, J. Theorie des kommunikativen Handels. Bd. 2. Frankfurt/M: Suhrkamp, 1981, p. 492-493. Cf. novamente Lohmann, G. Indiferenz und Gesellschaft, op. cit., Capítulo VI. (O grifo é nosso).

${ }^{34}$ Habermas, J. Strukturwandel der Öffentlichkeit. Frankfurt/M: Suhrkamp, 1990, p. 203.
} 
normativos em torno do trabalho assalariado, ou seja, em função da manutenção da autovalorização do capital apoiada na monetarização da força de trabalho. Essa estrutura da sociedade civil, desmascarada anatomicamente, revelaria o poder de um sistema que domina anonimamente a atividade concreta dos indivíduos e modela segundo sua própria imagem e forma a totalidade do entorno institucional para assim assegurar sua autoestabilização. "A anatomia da sociedade civil", comenta Habermas, "interpretada segundo conceitos da economia política, possui um efeito desmascarador: revela que o esqueleto que mantém coeso o organismo social não é mais o conjunto das relações de direito, mas sim o das relações de produção. A imagem extraída da medicina logo é substituída pelo venerável tesouro de metáforas relacionado à construção de uma casa: o direito faz parte da superestrutura política da base econômica de uma sociedade em que a dominação de uma classe social sobre as outras classes é exercido na forma apolítica do poder de disposição privado sobre os meios de produção. O círculo recursivamente fechado entre produção e reprodução dos valores de troca impõe-se ao direito e às suas realizações de integração social, reduzindo-o a um epifenômeno" ${ }^{, 35}$. Essa anatomia seria completada segundo o conhecido modelo da base (modo de produção) e da superestrutura (as formas pelas quais uma sociedade não apenas se representa, mas também se regula, tais como a política, direito, cultura, religião), reduzindo não apenas o direito, mas praticamente todos os modos de atividade não-econômica a epifenômenos das relações de produção ${ }^{36}$.

De acordo com esse modelo da base/superestrutura, o processo de autovalorização do capital não apenas se autonomizaria em face de estruturas da sociedade civil consideradas fundamentais (como, por exemplo, a religião, o direito, as instituições políticas, etc), mas as utilizaria para sua própria autoestabilização. As instituições que compunham a política burguesa não seriam determinantes das, mas sim determinadas pelas leis desse sistema. Por essa razão, da necessidade de organizar e integrar a sociedade de modo que esta pudesse perseguir seus interesses econômicos, surgiria o próprio Estado ${ }^{37}$. Na verdade, todas as instituições políticas que se encontram mediadas pelo Estado moderno estariam comprometidas com a manutenção e reprodução do sistema capitalista, com a administração

\footnotetext{
${ }^{35}$ Idem, p. 65. (Os grifos são nossos).

${ }^{36}$ Para uma clara exposição do modelo da base/superestrutura, ver Cohen, G. A. Karl Marx's theory of history. Princeton University Press, 1978, capítulo VIII. Cf. também Marcuse, H. Die Gesellschaftliche Lehre des sowjetischen Marxismus, op. cit., capítulo 6.

${ }^{37}$ Uma descrição detalhada sobre a teoria do Estado em Marx pode ser encontrada em Draper, H. Karl Marx's theory of revolution: The state and bureaucracy. Monthly Review Press, 2007, parte II; e Moore, S. Crítica de la democracia capitalista. Buenos Aires: Siglo XXI, 1971.
} 
"dos negócios comuns de toda a classe burguesa"38 "À medida que o progresso da indústria moderna desenvolvia, ampliava e aprofundava a oposição de classes entre capital e trabalho", segundo Marx, "o poder do Estado foi adquirindo cada vez mais o caráter de um poder público empregado para a opressão da classe trabalhadora, de uma máquina de dominação de classe",39.

Marx notou que o capitalismo liberal não poderia produzir processos de socialização simplesmente com base nas pretensas relações apolíticas estabelecidas entre as classes pela força estruturadora da forma salário. Pelo contrário, a relação entre trabalho assalariado e capital poderia se manter apenas se o Estado pudesse assegurar certos pressupostos gerais para a continuidade da produção capitalista e, por conseguinte, da mais valia ${ }^{40}$. Teria sido a atividade de complementação do mercado por parte do Estado que possibilitou que o poder social se exercesse por uma via apolítica de apropriação da mais valia produzida socialmente. E essa apropriação seria definidora da dominação e exploração do capital sobre o trabalhador assalariado. Por essa razão, o Estado não seria outra coisa, ainda nas palavras de Marx e Engels, senão "a forma de organização que os burgueses dão a si mesmos por necessidade, para garantir reciprocamente sua propriedade e seus interesses (...) Sendo o Estado, portanto, a forma pela qual os indivíduos de uma classe dominante fazem valer seus interesses comuns e na qual se resume toda a sociedade civil de uma época, conclui-se que todas as instituições comuns passam pela mediação do Estado e recebem uma forma política. Daí a ilusão de que a lei repousa na vontade, e mais ainda, em uma vontade livre, destacada da sua base concreta" 41 .

Uma vontade livre que adotasse uma forma política mediada pelo Estado se separaria do interesse social efetivo dos indivíduos e se tornaria uma comunidade política ilusória, pois "todas as lutas no interior do Estado, a luta entre democracia, aristocracia e monarquia, a luta pelo direito universal do voto, etc. não são senão formas ilusórias em que são travadas as lutas efetivas das diferentes classes" 42 . "Ilusórias" porque o discurso pretensamente universal em nome de uma vontade livre capaz de representar a todos os indivíduos por igual encontrar-seia comprometido com uma base concreta, em que as instituições políticas e as leis do Estado seriam parciais por apoiar sempre a autovalorização do capital. A política, nesse sentido, adotaria uma forma por meio da qual os interesses dos proprietários privados se imporiam

\footnotetext{
${ }^{38}$ Marx, K./Engels, F. Manifest der Kommunistischen Partei, op. cit., p. 464.

${ }^{39}$ Marx, K. Der Bürgerkrieg in Frankreich. In: Marx-Engels Werke. Band 17. Berlin: Dietz Verlag, 1964, p. 336.

${ }^{40}$ Cf. Draper, H. Karl Marx's theory of revolution: The state and bureaucracy, op., cit., p. 250-262.

${ }^{41}$ Marx, K./Engels, F. Deutsche Ideologie. In: Marx-Engels Werke. Band 3. Berlin: Dietz Verlag, 1990, p. 62.

${ }^{42}$ Idem, p. 33.
} 
sobre os interesses de toda a sociedade. O ideal universalista seria denunciado por esconder o seu verdadeiro caráter de máscara do interesse de classe burguês. Esse seria, segundo Marx e Engels, o dilema do universal vivido pelos indivíduos em uma democracia, ou seja, a própria democracia seria interpretada como uma forma ilusória de comunidade, pois o interesse universal se encontraria independente e alienado dos interesses efetivos de cada $\mathrm{um}^{43}$. “Assim”, comenta Habermas, "o interesse da burguesia não pode mais se identificar com o de todos os cidadãos; precisamente as leis gerais, em que se expressa o direito formal, tornam válidas o interesse particular de uma classe" ${ }^{\text {44 }}$. A crítica de Marx se dirige à idéia de uma sociedade civil que diz realizar igualmente todos os interesses e necessidades dos indivíduos. Sobretudo porque, em primeiro lugar, faltariam exatamente os pressupostos sociais para a efetivação da igualdade nessa sociedade, a saber, o status de proprietário. E como na sociedade capitalista as chances de ascensão social de assalariado para proprietário se tornam cada vez menores, a república democrática "contradiz o seu próprio princípio de acessibilidade universal"45. O Estado não representaria a vontade geral do povo, mas favoreceria a vontade particular de uma parcela da sociedade interessada em reforçar a dominação de classe. De forma alguma poderia ser um órgão de reconciliação dos conflitos de classe porque serviria, na verdade, "aos interesses dos proprietários privados e não aos interesses da sociedade em seu todo", permanecendo assim "instrumento da dominação"46.

É por essa razão que a idéia fundamental do marxismo sobre o papel histórico e o significado do Estado esteve intimamente ligada à representação dos interesses de classe e deveria ser indubitavelmente combatida na agenda da esquerda comunista. Lênin foi um dos que mais abertamente insistiu que "o Estado é o produto e a expressão da irreconciliação das oposições entre as classes. O Estado surge onde, quando e na medida em que as oposições entre as classes não puderem ser objetivamente reconciliadas. E ao contrário: a existência do Estado prova que as oposições entre as classes são irreconciliáveis" ${ }^{47}$. Que o Estado seja um órgão de dominação de uma determinada classe que de forma alguma poderia ser reconciliada com sua antípoda (a classe que lhe é oposta), "trata-se de algo que a democracia pequenoburguesa nunca compreendeu" 48 . Por seu turno, a própria "democracia consiste em um Estado

\footnotetext{
${ }^{43}$ Cf. idem, p. 34.

${ }^{44}$ Habermas, J. "Naturrecht und Revolution", op. cit., p. 115.

${ }^{45}$ Habermas, J. Strukturwandel der Öffentlichkeit, op. cit., p. 203. Cf. Marx, K./Engels, F. Deutsche Ideologie, op. cit., p. 47.

${ }^{46}$ Habermas, J. "Naturrecht und Revolution", op. cit., p. 116.

${ }^{47}$ Lenin, W. Staat und Revolution: Die Lehre des Marxismus vom Staat und die Aufgaben des Proletariats in der Revolution. In: Lenin, W. Ausgewählte Werke, Band 2. Moskau: Verlag für fremdsprachige Literartur, 1967, p. 161.

${ }^{48}$ Idem, p. 162.
} 
que reconhece a subordinação da minoria pela maioria, ou seja, uma organização que serve para uma aplicação sistemática do poder de uma classe contra a outra, de uma parte da população contra outra"49.

Ora, esse conjunto de considerações críticas reforçaria a denúncia de que, sobretudo no capitalismo, os homens não poderiam mais agir com base em sua autonomia e vontade, muito menos se organizar politicamente sem que tal institucionalização fosse determinada por um certo estágio do desenvolvimento de suas forças materiais de produção - que no capitalismo significa uma subordinação ao processo de valorização do capital. Ou seja, "a totalidade dessas relações de produção", segundo o próprio Marx, "constitui a estrutura econômica da sociedade, o fundamento real a partir da qual surge a estrutura política e jurídica e para a qual correspondem formas determinadas de consciência social. O modo de produção da vida material condiciona o processo da vida social, política e intelectual em seu conjunto. Não é a consciência dos homens que determina sua existência, mas sua existência social que determina sua consciência" ${ }^{\text {50 }}$. Por conseguinte, Marx pôde afirmar em seus Grundrisse que "a igualdade e a liberdade também não são respeitadas somente no intercâmbio, que se baseia no valor de troca, mas o próprio intercâmbio dos valores de troca constitui a base real de toda a liberdade e igualdade" ${ }^{\text {51 }}$. As formas jurídico-políticas da sociedade moderna e as normas que a constituem seriam criticadas como expressão necessária das relações de troca, ou seja, como reflexo jurídico de uma esfera de intercâmbio em que os compradores e vendedores livres e iguais trocam suas mercadorias por equivalentes ${ }^{52}$. A anatomia da sociedade moderna a reduz ao modo capitalista de produção. Segundo Cohen, "Marx vai tão longe a ponto de afirmar que o próprio capital cria a sociedade civil"

\footnotetext{
${ }^{49}$ Idem, p. 220.

${ }^{50}$ Marx, K. Zur Kritik der Politischen Ökonomie, op. cit., p. 8-9. (Grifo nosso). Cf. Lohmann, G. Indiferenz und Gesellschaft, op. cit., Capítulo VI.

${ }^{51}$ Marx, K. Grundrisse der Kritik der Politischen Ökonomie. In: Marx-Engels Werke, Band 42. Berlin: Dietz Verlag, 2005, p. 170.

${ }^{52}$ Oskar Negt sublinha que teríamos de levar às últimas conseqüências as considerações de Marx de que o direito, por exemplo, sempre está ancorado nas relações econômicas concretas, sobretudo na esfera da produção. A tese de que "o direito não tem uma história" seria fundamentada nessa dependência dos princípios e instituições da sociedade civil em relação à esfera econômica. E isso não significa que o direito seja algo "suprahistórico ou aistórico", comenta Negt, "mas representa sempre e antes de tudo um fenômeno social e político, pertence ao contexto efetivo e à totalidade concreta de uma formação social, e em última instância não consegue se separar dessa força de atração que o determina historicamente". Negt, O. "Thesen zur marxistischen Rechtstheorie". In: Kritische Justiz, I, Januar-März, 1973, p. 9. Não poderíamos deduzir as representações jurídicas senão do modo como surgem dos fatos econômicos, e estes sempre exprimem uma opressão fundamental. Por seu turno, o processo de troca regulado pelo direito burguês não é justo e igualitário, mas uma relação entre trabalhador e capitalista, "uma relação mediada pela produção a partir da qual todo o direito burguês retira sua substância histórica e sua validade”. Idem, p. 13.

${ }^{53}$ Cohen, J. Class and civil society: The limits of marxian critical theory, op. cit., p. 48.
} 
Portanto, a liberdade e a igualdade seriam denunciadas por serem constituídas no interior da racionalidade produtivista do capitalismo.

\section{A compreensão funcionalista da democracia e a auto-organização holista dos trabalhadores}

É da radicalidade da crítica da economia política que podemos interpretar virtudes e dificuldades da análise marxista. Se, por um lado, Marx foi fundamental na apreciação crítica da dinâmica interna do capitalismo, por outro lado, a ênfase na análise da lógica e dos limites do modo de produção capitalista resultaria restritiva. Marx pressupôs radicalmente que, no capitalismo, a economia surgiria como um sistema que penetra todos os aspectos da sociedade e remodela todas as relações sociais segundo sua própria imagem e forma. A primazia da esfera econômica, a centralidade da produção e o modelo da base/superestrutura compõem um sistema cuja lógica poderia ser articulada segundo categorias sócio-econômicas porque o capitalismo tende a subordinar e integrar as instituições políticas, jurídicas e sociais de acordo com seu próprio esquema reprodutivo. A atitude dos revolucionários, por essa razão, seria entendida certamente como uma atitude crítica diante do conjunto das instituições democráticas interpretadas como superestrutura. Embora as formas políticas que efetuariam a transformação revolucionária da sociedade burguesa em uma sociedade comunista ainda pudessem convergir, em algum momento, com tais instituições democráticas ${ }^{54}$, a verdadeira democracia seria caracterizada não por algum tipo de aperfeiçoamento administrativo ou de reforma política, mas fundamentalmente em função da transformação das relações materiais da vida, ou seja, das relações econômicas entre capital e trabalho ${ }^{55}$. Não pretendemos nesse momento entender essa tranformação da perspectiva do processo revolucionário enquanto tal, mas simplesmente as implicações que o modelo da base/superestrutura imporiam sobre a dimensão da auto-organização social e da constituição de uma comunidade de livres e iguais.

Duas linhas de interpretação permitiriam explicitar o papel instrumental da democracia para a orientação revolucionária. A primeira delas, de alcance limitado, seria encontrada nos textos em que a função da democracia, não mais interpretada com base no período do idealismo revolucionário, já começava a ser avaliada segundo uma abordagem teleológico-

\footnotetext{
${ }^{54}$ Cf. Texier, J. P. Revolução e democracia em Marx e Engels. Tradução de Duarte Pacheco Pereira. Rio de Janeiro: UFRJ, 2005, p. 22.

${ }^{55}$ Cf. Marx, K./Engels, F. Manifest der Kommunistischen Partei, op. cit., p. 489.
} 
materialista das transformações sociais ${ }^{56}$. Engels chegou a considerar, em um de seus textos sobre a situação da Inglaterra, que a democracia, na sua forma datada de uma república burguesa, representaria, de certo modo, um ganho na história da humanidade quando comparada com a situação de opressão e desigualdade a que a sociedade se viu submetida em outras formas de organização política do passado. Um dos pontos decisivos do argumento consistia em mostrar que as conquistas jurídico-políticas alcançadas pelo proletariado no quadro da democracia inglesa seriam indícios de uma tendência, irrefreável na história, de ganhos de liberdade. Nas palavras do próprio Engels: "A luta já está aí. A Constituição foi abalada em seus fundamentos. Como se formará o futuro, isso decorre de tudo que apresentamos aqui. Os novos e estranhos elementos na Constituição contêm uma natureza democrática; também a opinião pública, tal como se mostrou, desenvolve-se em direção ao lado democrático; o próximo futuro da Inglaterra será a democracia (...) Mas que tipo de democracia! Não aquela da Revolução Francesa, a qual se opunha à monarquia e ao feudalismo, mas $a$ democracia, que se opõe à classe média e ao proprietário. É isso que mostra todo o desenvolvimento procedente. A classe média e o proprietário dominam; o pobre não tem direitos, é oprimido, a Constituição o renega, a lei o destrata; a luta da democracia contra a aristocracia na Inglaterra é a luta contra os ricos. A democracia que surge na Inglaterra é uma democracia social" ${ }^{\text {"57. }}$.

Contudo, a democracia, mesmo que consistisse na possibilidade de uma nova democracia social, ainda seria criticada em relação a um estágio posterior e final nesse desenvolvimento irrefreável da história. Em sua forma histórica, a democracia representaria apenas um momento intermediário que levaria à verdadeira democracia, ao reino da liberdade efetiva, à real emancipação da sociedade. "A democracia", comentara Engels, "é somente um ponto de passagem, porém não para uma nova e melhorada aristocracia, mas para a efetiva liberdade humana" ${ }^{, 58}$."Pois a mera democracia", continua, "não é capaz de curar o mal social. A igualdade democrática é uma quimera, a luta dos pobres contra os ricos não pode ser travada no campo da democracia ou da política. Também esse passo é apenas uma transição, um último recurso meramente político que precisa ser empreendido e a partir do qual tem de se desenvolver um novo elemento, um princípio que está além de toda essência política. Esse

\footnotetext{
${ }^{56}$ Sobre a relação entre democracia e revolução nesse período, principalmente para o caso de Engels apresentado agora, ver Vranicki, P. Geschichte des Marxismus. Band 1, op. cit. p. 112-117. O jovem Marx da Crítica da filosofia do direito de Hegel apresentaria uma formulação diferente na sua crítica da sociedade civil e na consideração da democracia, como veremos na seção seguinte do presente capítulo.

${ }^{57}$ Engels, F. “Die Lage Englands”. In: Marx-Engels Werke. Band 1. Berlin: Dietz Verlag, 1961, p. 592.

${ }^{58}$ Idem, p. 548.
} 
princípio é o do socialismo" modo, uma avaliação positiva da democracia, quando a pensamos no interior do processo gradativo que levaria a um contexto social verdadeiramente justo, ao socialismo, seriam sempre as transformações diretas sobre as condições de trabalho, isto é, a "organização racional da produção"60, que definiriam o sentido da emancipação. A democracia, desde então, seria concebida somente como um estágio na realização histórica do socialismo ${ }^{61}$. Porém, seriam novamente nas categorias da crítica marxista madura que poderíamos encontrar a fundamentação mais consistente para apoiar o argumento de uma compreensão funcionalista da democracia.

Se a ordem democrática burguesa tem de ser entendida como reflexo de processos sociais injustos, como vimos, então apenas uma sociedade efetivamente livre e igual poderia expressar verdadeiramente princípios e normas cujos conteúdos não precisariam mais ser criticados em função do contexto em que se originam ${ }^{62}$. O problema consistiria em que a estrutura fundamental a ser considerada na transição para uma sociedade livre e igual teria de continuar vinculada a alguns fenômenos centrais que caracterizavam a base social e material por meio do qual ocorreria a autovalorização do capital ${ }^{63}$. E isso não apenas porque, ao diferenciar-se do socialismo utópico, Marx pretendeu fazer uma crítica imanente à lógica interna do funcionamento do sistema capitalista. Além disso, esse processo delinearia na teoria de Marx não apenas as condições de exploração, mas também um desenvolvimento que indicaria de forma imanente a possibilidade de transição ao socialismo, uma vez que a própria estrutura do capitalismo de livre mercado daria origem à produção industrial e aumentaria

\footnotetext{
${ }^{59}$ Idem, p. 592.

${ }^{60}$ Vranicki, P. Geschichte des Marxismus. Band 1, op. cit., p. 114.

${ }^{61}$ Cf. Fleischer, H. Marxismus und Geschichte. Frankfurt/M: Suhrkamp, 1969. Para uma crítica da teleologia da história, ver Habermas, J. "Einleitung: Historischer Materialismus und die Entwicklung normativer Strukturen”. In: Habermas, J. Zur Rekonstruktion des Historischen Materialismus. Frankfurt/M: Suhrkamp, 1976, p. 9-45.

${ }^{62}$ Para alguns autores, a crítica radical à democracia burguesa não desautorizaria Marx e seus seguidores a atribuir um papel positivo aos princípios jurídicos que organizam a sociedade moderna. A posição defendida por Mészáros, por exemplo, é a de que "os direitos humanos de 'liberdade', 'fraternidade' e 'igualdade' são, portanto, problemáticos, de acordo com Marx, não por si próprios, mas em função do contexto em que se originam". Mészáros, I. "Marxismo e direitos humanos". In: Mészáros, I. Filosofia, ideologia e ciência social. São Paulo, Ensaio, 1993, p. 207; ainda na mesma linha argumentativa, ver Planty-Bonjour, G. (org.). Droit et liberté selon Marx. Paris: Puf, 1986. Mas mesmo que a postura marxista consistisse então não em uma crítica a toda e qualquer institucionalização da liberdade, mas apenas em uma crítica ao contexto específico em que se originam e se aplicam os direitos, em todo caso qualquer um que pretendesse realizar uma teoria crítica marxista se defrontaria com o problema fundamental da dependência das instituições diante dos processos sociais na base da sociedade, e é esta dependência que parece determinar a oposição entre uma possível fundamentação burguesa e uma crítica marxista dos princípios democráticos. Cf. Müller-Schmid, P. Emanzipatorische Sozialphilosophie und pluralistisches Ordnungsdenken. Sttutgart: Seevald Verlag, 1976, principalmente cap. 2.

${ }^{63}$ Cf. Cohen, G. A. "Marx's dialectic of labor". Philosophy and public affairs. Vol. 3, n. 3, 1974. Cf. ainda Postone, M. Time, labor and social domination, op. cit., cap. 1. Embora Postone apresente nesse capítulo as linhas gerais do marxismo ortodoxo, é preciso lembrar que seu livro é uma tentativa de se opor a tal interpretação sem abandonar a categoria do trabalho.
} 
significativamente o montante da riqueza social. Foi principalmente o chamado marxismo ortodoxo o responsável por sublinhar que Marx defenderia a tese segundo a qual a dinâmica do capitalismo geraria assim as pré-condições técnicas, sociais e também organizacionais para a abolição da propriedade privada, a consecutiva reapropriação das forças produtivas pelo proletariado e seu planejamento centralizado da produção ${ }^{64}$. Em suma, a própria atividade econômica geraria as condições de superação da condição de trabalho heterônomo sob o capital $^{65}$.

Como a crítica da economia política mostrava que as instituições democráticas burguesas não eram senão obstáculos para que realizássemos uma transformação total do contexto de coerção que a própria sociedade moderna ajudaria a produzir, a emancipação não poderia ocorrer a partir da superestrutura, mas só poderia ser conquistada pela transformação de sua base, ou seja, no próprio âmbito do trabalho e do desenvolvimento das forças produtivas: diferentemente de sua superestrutura política determinada, apenas a base econômica consistiria em uma forma social que poderia se desenvolver historicamente em torno da produção e reprodução material. A superação das condições de opressão do proletariado sobre o trabalho heterônomo teria de levar em direção à realização da utopia de uma sociedade do trabalho autônomo ${ }^{66}$. O conceito de autonomia seria pensado em contraposição às determinações do trabalho heterônomo. Marx definiria a autonomia como a possibilidade de dispor novamente dos processos sociais que reproduzem a vida dos indivíduos, a capacidade de se reapropriar da produção e reprodução material que configuraria a base real da sociedade. Comentando esse "modelo de disposição", Habermas diz o seguinte: "Sabe-se que, no Capital, Marx explicitou o conceito de uma socialização intencional, aquela que se realiza com vontade e consciência, segundo um modelo que liga a figura do direito privado da associação civil - 'associação de homens livres' - com o arquétipo sócioprodutivista da comunidade de cooperação baseada na divisão do trabalho. Ele evidentemente

\footnotetext{
${ }^{64}$ Para uma análise dos conceitos de apropriação e reapropriação, ver Wildt, A. "Produtivkräfte und Soziale Umwälzung”. In: Honneth, A./Jaeggi, U. (Org.). Theorien des Historischen Materialismus, op. cit., p. 206-255.

${ }^{65}$ Há uma grande e rica controvérsia em relação à interpretação das obras de Marx no que diz respeito à questão de saber se essa superação em direção ao socialismo poderia contar apenas com um determinismo estrutural do próprio capitalismo - como parece ter exposto Marx no Capital - , prescindindo-se do caráter de autodeterminação da práxis revolucionária da luta proletária. Cf. as críticas de Lukács, G. "Was ist orthodoxer Marxismus?" In: Lukács, G. Geschichte und Klassenbewußtsein, op. cit., p. 175. Marcos Nobre acredita que Lukács se volta às obras do jovem Marx (referindo-se, nesse caso, à Miséria da Filosofia) justamente para poder apresentar a "determinação do sujeito revolucionário". Cf. Nobre, M. Lukács e os limites da reificação, op. cit., p. 73 e ss. As dificuldades da relação entre a lógica reprodutiva do capital e a luta de classes para a superação emancipatória serão abordadas em nossa segunda seção do presente capítulo.

${ }^{66}$ Cf. Lange, E. M. Das Prinzip Arbeit, op. cit., p. 193 e ss; em relação ao conceito de trabalho como perspectiva futura, ver também Albers, F- J. Zum Begriff des Produzierens im Denken von Karl Marx. Meisenheim am Glan: Anton Hain, 1975, p. 101 e ss. Para uma apreciação crítica, ver Honneth, A. "Arbeit und instrumentales Handel”, op. cit. 188 e ss.
} 
imagina a autonomia de uma sociedade que organiza a si mesma como exercício do controle consciente ou da administração planejada do processo de produção material: em analogia com a dominação da natureza, o sujeito social 'dispõe' do seu próprio processo de vida que se tornou objeto" ${ }^{97}$. O princípio democrático da autonomia seria traduzido ou mesmo substituído pela idéia de uma organização social baseada no arquétipo produtivista e as expectativas utópicas se dirigiriam "à esfera da produção, ou seja, para a emancipação do trabalho de toda determinação estranha"68. Pois o cerne do problema não plenamente resolvido no quadro do direito e da democracia seria aquele do domínio do trabalho "morto" sobre o trabalho "vivo". Somente os produtores associados poderiam, na medida em que dispusessem livremente de toda a riqueza produzida socialmente, realizar essa transformação ${ }^{69}$.

De um ponto de vista mais geral, a atividade do trabalho estaria atrelada, por um lado, às possibilidades objetivas inerentes à reprodução do capital, a qual passaria a determinar assim toda a reconstrução da divisão do trabalho, da dinâmica da luta de classes e do desenvolvimento das forças produtivas. Por outro lado, determinaria as condições de emancipação, seu processo revolucionário de transição e os traços de uma sociedade futura, justa e igual $^{70}$. Mas acrescenta-se a isso o fato de que, para consistir em um processo material de produção no qual estão contidas dialeticamente sua forma social específica (seja como trabalho escravo, seja como trabalho assalariado, etc.) e a atividade humana mais essencial, seria preciso pressupor que "o trabalho (...) é a condição básica mais primordial de toda a vida humana" ${ }^{, 71}$. O trabalho, mesmo circunscrito à sua realização heterônoma no processo social e material do trabalho assalariado, guardaria dialeticamente em si o germe da atividade humana genuína que precisaria ser libertado, da relação de apropriação e objetivação do homem sobre a natureza, da autorealização da vida na produção material ${ }^{72}$.

Com esse conceito produtivista de autonomia como disposição, seria possível entender a razão de a democracia ter sido considerada somente como um estágio em que finalmente a luta de classes se decidiria, pois a libertação do trabalho heterônomo visava à disposição

\footnotetext{
${ }^{67}$ Habermas, J. Faktizität und Geltung, op. cit., p. 393.

${ }^{68}$ Habermas, J. "Die Krise des Wohlfahrstaates und die Erschöpfung utopischer Energien”, op. cit., p. 162.

${ }^{69}$ Cf. Negt, O. "Thesen zur marxistischen Rechtstheorie", op. cit, p. 9. Cf. ainda Negt, O. Lebendige Arbeit: Enteignete Zeit. Frankfurt/M, 1984.

${ }^{70}$ Cf. Engels, F. "Die Entwicklung des Sozialismus von der Utopie zur Wissenschaft". In: Marx-Engels Werke. Band 19. Dietz Verlag, 1962, principalmente p. 219 e ss. Também Engels, F. , F. Herr Eugen Dührings Umwälzung der Wissenschaft (Anti-Dühring). In: Marx-Engels Werke. Band 20. Berlin: Dietz Verlag, 1969, parágrafo 3 .

${ }^{71}$ Engels, F. Dialektik der Natur. In: Marx-Engels Werke. Band 20. Berlin: Dietz Verlag, 1969, p. 444. Engels chega a dizer na mesma passagem que foi o próprio trabalho que "criou o homem". Cf. também Marx, K. Das Kapital. Vol. 3, Band 25, op. cit., p. 826.

${ }^{72}$ Cf. Lange, E. M. Das Prinzip Arbeit, op. cit., capítulo 2.
} 
comunitária das condições materiais da vida, da autoatividade produtiva, e a possibilidade de um novo modo de distribuição, justo e racionalmente regulado. Marx supunha que somente as relações eqüitativas na base econômica gerariam princípios verdadeiramente democráticos para a auto-organização dos trabalhadores. Uma vez estabelecidas as condições de disposição e controle consciente do processo de produção material, tudo indicaria que um suposto reflexo da nova base econômica sobre a nova superestrutura política não mais precisaria ser criticado em função de seu contexto de surgimento. Uma reflexão sobre e democracia seria então duplamente enfraquecida. Primeiramente devido à anatomia da sociedade civil que apresentava uma subordinação da superestrutura aos imperativos do capital, justificando as críticas de Marx ao direito e à democracia existentes. Além disso, partindo de uma analogia, a anatomia da sociedade comunista mostraria, por seu turno, que a realização da liberdade e a organização coletiva decorreriam imediatamente das condições do trabalho autônomo conquistadas na base. Com a emergência de uma sociedade organizada por produtores associados, que passariam a se socializar de forma transparente, imediata e direta, Marx poderia inclusive abrir mão da necessidade de mediações jurídico-políticas como formas de organização da liberdade e da igualdade. O conceito de liberdade significaria libertação em relação aos fetiches do capital (ou libertação das forças produtivas) e não seria formulada em termos de liberdade política.

A Crítica ao programa de Gota é um dos textos tardios exemplares em que Marx expõe com mais detalhes suas idéias sobre o Estado de direito e a democracia, embora também adotasse diante das instituições políticas da república democrática uma relação puramente instrumental. Pois, ainda munido desse conceito de disposição para compreender a autonomia, desapareceria da análise de Marx justamente "o núcleo do problema de uma autoorganização social, a saber, a constituição e a autoestabilização de uma comunidade de livres e iguais"73. Marx, preocupado em esclarecer as condições sociais e políticas a serem preenchidas para a realização da emancipação proletária, refutaria veementemente todos os elementos ainda presos ao vocabulário jurídico-político burguês presentes no Programa dos trabalhadores alemães, pois aqueles constituiriam exigências políticas que não contêm "nada além das ladainhas democráticas conhecidas em todo o mundo: sufrágio universal, legislação direta, direito das gentes e suas garantias jurídicas, etc. Elas são um mero eco dos partidos populares burgueses, das coligações pela paz e pela liberdade" ${ }^{\text {74 }}$. Em oposição à república democrática considerada vulgar, Marx seria explícito ao defender a tese de que a sociedade

\footnotetext{
${ }^{73}$ Habermas, J. Faktizität und Geltung, op. cit., p. 393.

${ }^{74}$ Marx, K. Kritik des Goather Programms. In: Marx-Engels Werke. Band 19. Berlin: Dietz Verlag, 1962, p. 29.
} 
comunista seria a única forma de realização da verdadeira democracia. Uma nova concepção de direito, para não ser meramente formal e nem repetir as "ladainhas democráticas", teria de ser pensada também como reflexo - contudo, neste caso, como a expressão formalizada dos processos e conteúdos sociais de uma realidade inteiramente transformada. Nas palavras de Nicolas Guillot, Marx confirmaria com isso a sua tese da subordinação da superestrutura política em face da configuração das relações sócio-econômicas de base mesmo na transição ao comunismo: "O Estado e a ordem jurídica são reflexos formalizados das formações sociais específicas, e têm de mudar com estas últimas"75.

Porém, com tal reposição do modelo da base/superestrutura, tudo levaria a crer que os direitos pretensamente iguais e universais tenderiam a desaparecer com o desenvolvimento material da sociedade em direção à consolidação do comunismo. Segundo Marx, "em uma fase superior da sociedade comunista, em que a subordinação escrava dos indivíduos sob a divisão do trabalho, e com isso também a oposição entre trabalho espiritual e corporal tiver desaparecido; depois que o trabalho for não somente um meio para a vida, mas também a necessidade primeira da vida; depois que o desenvolvimento universal dos indivíduos também aumentar suas forças produtivas e jorrar plenamente todas as fontes da riqueza cooperativa somente então o horizonte do direito burguês pode ser totalmente ultrapassado e a sociedade escreverá em sua bandeira: cada um segundo suas capacidades, a cada um segundo suas necessidades!"76. Isso significaria que o princípio normativo "cada um segundo suas capacidades, a cada um segundo suas necessidades" se justificaria a partir das forças produtivas plenamente desenvolvidas de uma sociedade transformada, que se encontraria em condições de satisfazer materialmente as necessidades de todos e assegurar, finalmente, a liberdade e a igualdade com base na disposição coletiva da produção. Substituindo as relações jurídico-políticas que caracterizariam a república democrática, a realização histórica do trabalho autônomo seria a condição fundamental da emancipação e do critério de justiça, ou seja, a emergência do trabalho e das forças produtivas como a base da vida social e da riqueza ${ }^{77}$. Contudo, com esse modelo produtivista de autorealização, nota Cohen, a "liberdade tende a ser sacrificada em nome da abundância"78.

\footnotetext{
${ }^{75}$ Guillot, N. "The transition to the human world of democracy: Notes for a history of a concept of transition, from early Marxism to 1989”. In: European Journal of Social Theory, 2002, 5, p. 225.

${ }^{76}$ Marx, K. Kritik des Goather Programms, op. cit., p. 21.

${ }^{77}$ Cf. Dahrendorf, R. Marx in Perspektive. Die Idee des Gerechten im Denken von Karl Marx. Hannover: Dietz, 1952, capítulo V.

${ }^{78}$ Cohen, J. Class and civil society: The limits of Marxian critical theory, op. cit., p. 110. Cohen é ainda mais enfática na sua crítica a tal substituição: "Mas essa alternativa é quixotesca. Pois a imagem de uma sociedade futura orientada à satisfação universal das necessidades e à produção para o uso não apresenta qualquer
} 
Conclui-se que mesmo nesse texto de Marx não haveria "nenhuma palavra a respeito da institucionalização da liberdade: sua imaginação institucional não vai além da ditadura do proletariado prevista para o "período de transição"",79. E isso nos remete à conhecida e controversa passagem em que Marx se pergunta finalmente quais funções, na sociedade comunista, permanecerão e serão análogas àquelas do Estado de direito burguês, respondendo-a do seguinte modo: "Entre a sociedade capitalista e a comunista reside o período de transformação revolucionária de uma à outra. A este corresponde também um período de transição política, na qual o Estado pode existir apenas como a ditadura do proletariado", 80 .

A caracterização desse processo como "período de transição" já permite circunscrever a função meramente instrumental do Estado para a emancipação do proletariado, pois as condições futuras de uma sociedade emancipada - ainda que compreendamos esta como uma verdadeira democracia - parecem não incluir quaisquer traços das instituições políticojurídicas que organizavam a sociedade civil, circunscrevendo-se à imagem produtivista de auto-organização $^{81}$. Desde a publicação da Ideologia alemã, o Estado serviria apenas como um meio para o objetivo da luta proletária, o qual consistiria na reapropriação coletiva dos meios de produção, e tal reapropriação não apenas definiria a principal característica de uma sociedade que se autodetermina e se emancipa das condições do trabalho heterônomo, mas que também, no final das contas, exige a supressão desse mesmo Estado para sua efetivação. Segundo Engels, "o proletariado toma o poder do Estado e em seguida transforma os meios de produção em propriedade do Estado. Mas com isso cessa o próprio proletariado, com isso cessam todas as distinções e oposições de classe, e com isso cessa também o Estado enquanto Estado. (...) O primeiro ato, no qual o Estado aparece efetivamente como representante de toda a sociedade - a apropriação dos meios de produção em nome da sociedade - é

alternativa real para a lógica capitalista; ela apenas realiza o outro lado desta lógica, das formas do valor, abstraindo-as em uma alternativa fetichizada às relações de troca“. Idem, p. 187.

${ }^{79}$ Habermas, J. "Die nachholende Revolution und linker Revisionsbedarf: Was heißt Sozialismus heute?”, op. cit., p. 190.

${ }^{80}$ Marx, K. Kritik des Goather Programms, op. cit., p. 28.

${ }^{81}$ No primeiro estágio do comunismo (período caracterizado pela "ditadura do proletariado"), o aparelho do Estado seria usado para a implementação de um novo poder político. O proletariado poderia organizar a produção, distribuição, crédito, comunicação, transporte, etc. Não se trata de forma alguma de uma abolição do trabalho, pois esse Estado comunista imporia o trabalho a todos. A abolição da propriedade privada nos meios de produção e de todas as classes em nome de um interesse geral implicaria a dissolução de todas as instâncias entre Estado e sociedade. Mas não seria improvável que Marx pensasse a expansão das forças produtivas vinculada ao desenvolvimento de um aparelho estatal centralizado, como já havia feito na Ideologia alemã. Cf. Draper, $\mathrm{H}$. Karl Marx's theory of revolution III: The "Dictatorship of the proletariat”. Monthly Review Press, 1978. Para uma análise do conceito na tradição marxista, ver Draper, H. The "dictatorship of the proletariat" from Marx to Lenin. New York: Monthly Review Press, 1987. Cf. ainda Fausto, R. "Kautsky e a crítica do bolchevismo: Bolchevismo e poder burocrático”. In: Fausto, R. A esquerda difícil. São Paulo: Perspectiva, 2007, p. 97-133. 
igualmente seu último ato autônomo como Estado" ${ }^{\text {}} 82$. E em uma passagem de seu conhecido Estado e revolução, no qual faz referência ao trecho de Engels citado acima, Lênin reforça que não somente tal supressão do Estado teria necessariamente de ocorrer logo após a apropriação dos meios de produção pelo proletariado. De acordo com o autor, "todos nós sabemos que a forma política do Estado neste momento seria a forma mais perfeita de democracia" 83 . "Porém", continua Lênin, "Engels fala também do 'falecimento' ou 'morte' da democracia. Em um primeiro momento isso pode parecer um tanto duvidoso. Mas é 'incompreensível' não se ter pensado que a democracia também é um Estado e, por conseguinte, também desaparecerá logo que o Estado desaparecer. Apenas a revolução pode ‘superar' o Estado burguês" ${ }^{\prime 4}$. A supressão do Estado também significa uma supressão da democracia: "a morte do Estado também é uma morte da democracia" 85 .

Se a estrutura econômica na base da sociedade sempre tem predominância na determinação da constituição social, então o uso de instituições políticas do Estado como um instrumento no período de transição tem o intuito de torná-lo, no fim das contas, sem uso. Em outros termos, a superestrutura política seria dissolvida nas relações sócio-econômicas emancipadas da base. É isso que nos explica Guillot: "Em um segundo e superior estágio, as estruturas que deveriam manter a dominação de classe, tais como o Estado e o direito, perderão eventualmente sua raison d'être e deixarão de existir (...) Marx rejeitou repetidas vezes qualquer possibilidade de realização da transição política com o uso do Estado. A ditadura do proletariado não contradiz este princípio" ${ }^{\Perp 6}$. Por conseguinte, pouco ou quase nada em relação a alguma preocupação com uma imaginação institucional pode ser retirada das reflexões sobre a ditadura do proletariado. "Procuraremos em vão", continua Guillot, "qualquer proposta positiva, específica, sobre a forma institucional e política que a transição poderia adotar" ${ }^{\prime 87}$.

Não entendemos que a crítica à orientação revolucionária siga nessa direção, ou seja, que se trate simplesmente de cobrar de Marx uma reflexão sobre alguma proposta positiva de institucionalização que a transição poderia adotar. Provavelmente o problema seja justamente pensar os limites dos possíveis modelos de comunismo e de seus pressupostos que, ao que

\footnotetext{
${ }^{82}$ Engels, F. Herr Eugen Dührings Umwälzung der Wissenschaft (Anti-Dühring), op. cit., p. 261-262.

${ }^{83}$ Lênin, W. Staat und Revolution: Die Lehre des Marxismus vom Staat und die Aufgaben des Proletariats in der Revolution, op. cit., p. 170.

${ }^{84}$ Ibidem.

${ }^{85}$ Idem, p. 220.

${ }^{86}$ Guillot, N. "The transition to the human world of democracy: Notes for a history of a concept of transition, from early Marxism to 1989”, op. cit., p. 225.

${ }^{87}$ Ibidem.
} 
tudo indica, preencheriam a lacuna correspondente que resultaria das críticas aos princípios constitutivos da república democrática ${ }^{88}$. De um lado, haveria o modelo utópico de uma sociedade da qual se esperaria que fosse capaz de espontaneamente se determinar e organizar a si mesma em sua totalidade: "Sobre as características institucionais específicas da sociedade comunista", comenta o próprio Guillot, "elas foram deixadas para a capacidade inovadora dos movimentos proletários de gerar novas formas de associações livres" ${ }^{\sharp 9}$. De outro lado, contudo, imperou o seu oposto, a saber, a burocratização estatal e o centralismo partidário que marcaram fortemente a experiência do socialismo realmente existente ${ }^{90}$.

Um dos pressupostos mais decisivos na crítica de Marx à sociedade civil consistiria no fato de sua teoria estar amparada pelo conceito clássico, que persistiu de Aristóteles até Hegel, de totalidade. "No lugar da unidade manifesta de uma ordem estatal constituída juridicamente", comenta Habermas, "entra a unidade latente e sistemicamente produzida do processo econômico de autovalorização do capital em seu conjunto. E este, enquanto totalidade negativa, continua sendo referido filosofica e historicamente à imagem clássica de uma totalidade produzida conscientemente" ${ }^{91}$. Esta totalidade não mais abstrata estaria presente tanto nos textos fundados em uma perspectiva da teleologia da história - na qual a sociedade poderia ser entendida como "totalidade em vir-a-ser", isto é, como sendo capaz de restituir os processos materiais de reprodução de sua própria vida anonimizados pelo capital no decorrer do processo histórico - como na sua interpretação da integração social induzida pelos imperativos do sistema econômico. Como vimos, a totalidade seria entendida como totalização das relações capitalistas, as quais, segundo a estrutura do paradigma produtivista, poderia ser interpretada como uma forma social (uma totalidade social) cujos mecanismos de reprodução de sua base material centrados na economia determinariam sua superestrutura, a qual, por sua vez, refletiria a estrutura desse paradigma. Mas além disso, seria ainda mais importante notar agora que Marx teria pressuposto esse conceito de totalidade também em sua representação holista das condições de trabalho autônomo. Essa totalidade se efetivaria "como associação futura dos produtores libertos do fetiche do capital, os quais submetem as condições dos processos materiais da vida ao seu controle comunitário" 92 .

\footnotetext{
${ }^{88}$ Esse também é o argumento elaborado por Wellmer em 'Bedeutet das Ende des 'realen Sozialismus' auch das Ende des Marxschen Humanismus?", op. cit., p 81 e ss.

${ }^{89}$ Guillot, N. "The transition to the human world of democracy: Notes for a history of a concept of transition, from early Marxism to 1989", op. cit., p. 225.

${ }^{90}$ Cf. Fausto, R. "Totalitarismo". In: Fausto, R. A esquerda difícil, op. cit., p. 9-32.

${ }^{91}$ Habermas, J. Faktizität und Geltung, op. cit., p. 65.

${ }^{92}$ Idem, p. 66. Para uma reconstrução do conceito de totalidade em Marx e seus desdobramentos na noção de emancipação, produção e um holismo de tipo materialista, ver Rundell, J. Origins of modernity. The origins of modern social theory from Kant to Hegel to Marx, op. cit., p. 111-145. Para a retomada dessa noção em Marx a
} 
De acordo com o primeiro modelo de uma auto-organização espontânea dos trabalhadores, provavelmente a função social de controle e de regulação dos conflitos na sociedade socialista passaria a não mais depender de formas políticas burguesas porque provavelmente se esperaria que as leis e normas fossem internalizadas e se tornassem hábitos. O problema nesse caso, segundo o argumento de Habermas, consistiria em que "a ilusão santsimonista quanto à 'gestão das coisas' faz diminuir a tal ponto a esperada necessidade de uma solução democraticamente regulada dos conflitos, que tal solução pode ser aparentemente deixada para a auto-organização espontânea de um povo rousseauista"93. Prescindindo das condições de institucionalização da liberdade e de uma formação igualitária da vontade, a sociedade comunista estaria limitada à representação holista de uma sociedade do trabalho associada livremente e que, após se apropriar dos meios de produção, encontraria por si mesma os meios de sua convivência.

O nexo funcional entre estrutura de classe e sistema do direito implicaria, assim, pensar uma sociedade política de uma nova perspectiva, ou seja, de uma perspectiva não regulada pelas instituições políticas burguesas e que precisa, porém, organizar-se socialmente por outros meios. No caso, prescinde-se do Estado em função de uma organização política determinada como uma associação livre de trabalhadores, em que o nexo de solidariedade seria suficiente para a integração social em seu conjunto, para a manutenção não mais de uma sociedade constituída por fábricas, mas de uma única "fábrica da sociedade" "94. A Comuna de Paris, segundo Habermas, seria uma possível realização dessa "associação livre": "Marx e Engels deram-se por satisfeitos com algumas observações sobre a Comuna de Paris, deixando mais ou menos de lado questões sobre a teoria da democracia"95. Ao conceito de autoorganização não correspondia nenhuma compreensão aprofundada dos modos de funcionamento, das formas de comunicação e das condições de institucionalização da formação igualitária da vontade, pois "a diretriz continuou sendo", explica Habermas, "a idéia holística de uma sociedade politizada de trabalhadores. Os primeiros socialistas ainda tinham confiança em que, a partir de uma produção organizada corretamente, as formas de convivência entre trabalhadores associados livremente surgiriam por si. Essa idéia de uma

partir de Hegel, Feuerbach e Moses Hess, ver Lange, M. Der Prinzip Arbeit, op. cit, capítulo 2. Sobre a recepção do conceito no marxismo ocidental, ver ainda Jay, M. Marxism and totality, op. cit.

${ }^{93}$ Habermas, J. "Die nachholende Revolution und linker Revisionsbedarf: Was heißt Sozialismus heute?", op. cit., p. 190-191.

${ }^{94}$ Cf. Southall, A. "Stateless Society". In: International encyclopedia of the social sciences. Vol. 15, p. 158 e ss. Cf. ainda Adler, M. Die solidarische Gesellschaft. Wien, 1964, p. 54 e ss.

${ }^{95}$ Habermas, J. "Volkssouveränität als Verfahren", op. cit., p. 617. Também para Gilbert, a defesa de Marx da Comuna de Paris seria insuficiente - e mesmo paradoxal - para pensar a questão da democracia radical. Cf. Gilbert, A. "Political philosophy: Marx and radical democracy". In: Carver, T. The cambridge companion to Marx. Cambridge University Press, 1991, p. 169. 
autoadministração dos trabalhadores teve de fracassar diante da complexidade de sociedades altamente desenvolvidas e funcionalmente diferenciadas; e isso mesmo tendo a utopia da sociedade do trabalho sido representada, com Marx, enquanto reino da liberdade que tem de ser erigido sobre a base de um reino da necessidade contínuo e regulado de maneira sistêmica. Também a estratégia de Lênin do exercício do poder por revolucionários não pôde suprir o que faltava à teoria política" 96 . O abandono da teoria da democracia teve consequiências práticas cujo déficit se mostrou naquelas aporias em que o socialismo burocrático se enredou com "uma vanguarda política solidificada em nomenklatura"97.

"Não deveríamos nos surpreender", comenta Cohen sobre o mesmo ponto, "que os modelos de comunismo associados [com a teoria de Marx] sejam ou o romântico/utópico (...) ou o estatista/autoritário" 98 . Segundo a autora, a redução dos processos sociais políticos à dinâmica dos modos de produção implicaria um modelo de sociedade comunista que preservaria a lógica produtivista de uma forma problematicamente mais racionalizada e centralmente planejada. A utopia de uma comunidade de trabalhadores livremente associados não poderia sobreviver à integração sistêmica de uma lógica reprodutiva das relações econômicas. Porém, "o maior perigo", continua Cohen, "em assumir que as normas e instituições sociais não-econômicas possuem sua gênese ou 'verdade' nas relações econômicas reside na tendência correspondente (...) a rejeitar os princípios universalistas da democracia como meramente burgueses e a forçar a abolição de toda a sociedade civil. A destruição do sistema capitalista parece exigir a destruição da sociedade civil (incluindo seus suportes jurídicos e institucionais) como precondição para a realização da liberdade e igualdade 'substantivas'. O erro dessa argumentação consiste em acreditar que a formalidade das normas e das leis é a base para a carência de realização substantiva, em vez de entender que seu caráter ideológico reside exatamente no fato de que tais normas e leis não eram formais o suficiente" ${ }^{99}$. Por conseguinte, a redução sociológica dos princípios e instituições da sociedade civil ao modo de produção capitalista se tornaria tão determinante que a abordagem marxista implicaria, no limite, uma mudança de uma postura crítica à mera reposição e reprodução de sua lógica. A autora chega a afirmar que não haveria alternativa no modelo comunista de Marx à visão "apolítica, estatista e tecnocrática": "Para uma análise que considerasse a multiplicidade de grupos de interesse, de associações voluntárias e de públicos da sociedade civil moderna como uma fragmentação particularista resultante das relações de

\footnotetext{
${ }^{96}$ Habermas, J. "Volkssouveränität als Verfahren”, op. cit., p. 617-618.

${ }^{97}$ Idem, p. 618.

${ }^{98}$ Cohen, J. Class and civil society: The limits of Marxian critical theory, op. cit., p. 42.

${ }^{99}$ Idem, p. 49.
} 
classe capitalistas, a sociedade futura poderia ser vista somente como totalmente socializada, resolvendo os antagonismos entre indivíduo e sociedade, universal e particular, nas relações sociais organizadas por meio de um planejamento racional consciente" ${ }^{\text {100 }}$. Cohen não deixa de frisar que essa visão de uma comunidade totalmente socializada que prescinde de uma séria reflexão sobre a institucionalização da liberdade estaria apoiada em um "perigoso mito"

Essa solução mais utópica do modelo comunista seria ainda "essencialmente antimoderna”. A classe proletária seria uma comunidade de indivíduos concretos e diferenciados, porém se organizariam como uma totalidade com base em um interesse universal e na produção socializada. E na medida em que os interesses do proletariado poderiam ser considerados verdadeiramente universais, não haveria conflito entre indivíduo e sociedade, universal e particular. A subsunção das forças produtivas sob um controle consciente dos trabalhadores eliminaria a externalidade das condições de classe, tornando completamente transparente as relações sociais e materiais. "Isso seria possível”, insiste Cohen, "porque a comunidade de classe é uma coletividade socializada; sua produção socializada e suas forças produtivas coletivizadas se tornam o modelo de organização de uma sociedade comunista em que as classes são abolidas porque todos se tornarão um produtor (um produtor associado!). Em suma, porque o proletariado já é uma entidade social plena, porque seu trabalho é diretamente coletivo, sem qualquer característica ou propriedades individuais, a tensão entre o indivíduo 'burguês' egoísta abstrato e a comunidade política abstrata se dissolve em uma sociedade comunista sem a ajuda das instituições políticas" ${ }^{" 102}$. As críticas de Marx à sociedade burguesa o levariam, assim, de um extremo ao outro. Corre-se o risco de dissolver a individualidade e a esfera da autonomia privada na comunidade comunista plenamente socializada em que a a totalidade das relações sociais integradas pela produção se tornariam o único modelo possível de socialização. Ora, "esse ideal pseudo-emancipatório com seu fetiche das relações sociais apenas exerce violência contra a individualidade ao ignorar a diferença desta diante da esfera do social e do comunal, dissolvendo-a na coletividade"103.

Mesmo quando Marx recusa mais abertamente o uso do Estado para a autoorganização do proletariado, não parece possível se desvencilhar do problema da organização sistêmica racionalmente planejada. A Comuna de Paris representaria para Marx uma alternativa radical ao Estado burguês, pois possibilitaria a abolição do aparato estatal e, além

\footnotetext{
${ }^{100}$ Idem, p. 51.

${ }^{101}$ Ibidem. O conceito de classe concebido como uma "comunidade" consistiria naquele perigoso mito que Weber já teria denunciado, por sacrificar o indivíduo em uma comunidade ilusória. Cf. Weber, M. "Class, status, party”. In: Gerth, H./Mills, W. (org) From Max Weber. New York: Oxford University Press, 1985, p. 180 e ss.

${ }^{102}$ Cohen, J. Class and civil society: The limits of Marxian critical theory, op. cit., p. 107.

${ }^{103}$ Ibidem.
} 
disso, poderia ser pensada inclusive como um modelo democrático de participação direta. $\mathrm{O}$ desmantelamento do exército, do aparato administrativo da burocracia, da polícia e do judiciário e sua substituição pela milícia popular, um corpo eleito de protetores da comuna, etc., eram algumas das medidas que seriam realizadas pela Comuna de Paris ${ }^{104}$. Sua intenção era reestruturar a sociedade civil burguesa com uma organização que visava assegurar a participação dos cidadãos na vida política. Contudo, a sociedade emancipada ainda assim seria apresentada como a totalidade de uma sociedade de produtores, como a tão esperada "República do Trabalho"105: embora ocorresse a emancipação do trabalho heterônomo e a abolição das classes, a revolução transformaria todo o homem em um "homem trabalhador" ${ }^{\prime 106}$. Tudo indica que novamente a centralização da produção entrevista pela Comuna criaria a necessidade de um Estado (ou de algum órgão semelhante) que conservasse sua própria reprodução ${ }^{107}$.

Além disso, o tratamento instrumental do Estado significaria, no limite, não apenas a dissolução de seus órgãos administrativos, mas da própria política. Na verdade, o Estado não poderia desaparecer totalmente, uma vez que funcionalmente se manteria na forma de alguma instância administrativa da sociedade. O que acabaria sendo desconsiderado seria, portanto, uma preocupação fundamental a respeito da "interação política". Pois "a imagem santsimonista serve como um substituto perfeito para a ideologia tecnocrática da administração total que se diz isenta de interesses por parte dos chamados Estados comunistas" ${ }^{108}$. É evidente que Marx não imaginava ter fomentado as bases para a dominação totalitária de um partido ao denunciar as formas políticas da democracia que, segundo ele, o comunismo poderia rejeitar. Infelizmente, porém, "a necessidade de instituições políticas, de espaço para a reflexão sobre a interpretação de valores, normas e necessidades (política no sentido clássico da palavra), para a articulação de mecanismos que permitissem um compromisso entre interesses, foi desnecessariamente rejeitada. Em suma, a teoria das classes do materialismo histórico considerou resolvido o problema sobre os 'fins'. A revolução seria meramente uma questão sobre os "meios"",109.

Essas críticas mostrariam que em Marx o círculo recursivamente fechado de produção e reprodução dos valores de troca se imporia sobre as funções sócio-integradoras da ordem

\footnotetext{
${ }^{104}$ Cf. Marx, K. Der Bürgerkrieg in Frankreich, op. cit., Parte III.

${ }^{105}$ Idem, p. 344.

${ }^{106}$ Idem, p. 342.

${ }^{107}$ Cf. Cohen, J. Class and civil society: The limits of Marxian critical theory, op. cit., p. 131 e ss; também p. 184-185.

${ }^{108}$ Idem, p. 108.

${ }^{109}$ Ibidem.
} 
jurídica e política com tal força que sua crítica social acabaria por empreender uma redução funcionalista da democracia. As instituições da sociedade civil, consideradas superestrutura, seriam desmascaradas ao serem criticadas como meros reflexos do desenvolvimento das forças produtivas e das relações de produção, e essa crítica inviabilizaria em grande medida uma consideração futura do direito e da democracia na qual fosse possível lhes atribuir ainda algum potencial emancipatório legítimo. A crítica da economia política denunciaria as condições sociais do trabalho heterônomo e consideraria emancipatório apenas uma reapropriação coletiva das forças produtivas, reduzindo assim as instituições da liberdade a um papel meramente funcionalista no processo de transformação social e de efetivação de uma sociedade do trabalho autônoma.

Por essa razão, as categorias jurídico-políticas não teriam mais uso - a não ser aquele instrumental no período de transição - porque se pressupunha uma concepção fechada e congelada de sociedade produtiva na qual os princípios e normas que a regulam não estariam mais em disputa, e se deduziria uma imagem de sociedade livre e igual a partir das relações materiais tornadas eqüitativas e da conseguinte socialização tornada transparente. Segundo nossa interpretação, esse congelamento e essa antecipação de uma imagem de uma sociedade plenamente auto-organizada e baseada na divisão do trabalho não permite mais entender a emancipação como um processo intersubjetivo, aberto e reflexivo, de constante disputa e negociação. Esse processo político, em que noções como liberdade e igualdade estariam constantemente recebendo uma configuração histórica em disputa, constitui o cerne de uma concepção de democracia radical abandonada em detrimento da utopia moderna de uma sociedade do trabalho. Poderíamos concordar com a afirmação de Ulrich Preuß de que "por mais que possa parecer paradoxal e também conservador, um 'conceito radical de democracia' também está apoiado (...) em instituições"110, mas em um sentido muito específico. Uma transformação social radicalmente democrática tornaria necessária uma distinção, deixada de lado pelos comunistas, entre a idéia de uma justificação do poder político e a institucionalização (e não instituição) ${ }^{111}$ deste nível de justificação, que muda conforme as circunstâncias. Por um lado, a democracia burguesa criticada pelos marxistas poderia ser criticada também com base na idéia de um processo radicalmente democrático de formação da vontade mais inclusiva, em que todos pretenderiam poder participar da forma mais livre e igual na auto-organização da sociedade. Por outro lado, nada impediria que

\footnotetext{
${ }^{110}$ Preuß, U. "Was heißt radikale Demokratie heute?". In: Die Ideen von 1789 in der deutschen Rezeption. Frankfurt/M: Suhrkamp, 1989, p. 63.

${ }^{111}$ Cf. Habermas, J. Faktizität und Geltung, op. cit., p. 234. Cf. ainda Melo, R. "Habermas e a estrutura ,reflexiva' do direito". In: Revista Direito GV, 1, 2005, p. 67-78. Também Castoriadis, C. A instituição imaginária da sociedade. São Paulo: Paz e Terra, 2007.
} 
pensássemos em uma organização política de discursos e deliberações formadores da opinião e da vontade, que em determinadas circunstâncias poderia se tornar bem parecida com esta idéia. E disso não se conclui que "a transição ao socialismo, da forma que se queira imaginála em sociedades como as nossas, não produziria alguma alteração nas instituições políticas existentes - ou que não deveria alterar nada"112.

A compreensão funcionalista parece ser um dos resultados mais preocupantes da dissolução sociológica e com mais conseqüências práticas para a auto-reflexão da esquerda contemporânea, a partir da qual se estabeleceu uma separação radical entre revolução e democracia. Segundo Habermas, "com a crítica ao Estado de direito burguês (...) Marx desacreditou de tal maneira a idéia da juridicidade (Rechtlichkeit) e a intenção do direito natural enquanto tal, dissolvendo sociologicamente a base dos direitos naturais, que o vínculo entre revolução e o direito natural se desfez. Os partidos de uma guerra civil internacional dividiram o legado de modo desastroso: um dos lados assumiu a herança da revolução, o outro a ideologia do direito natural"113. Além disso, ao manter-se no horizonte da sociedade do trabalho, a crítica da economia política reduziria também a compreensão da práxis política autônoma a epifenômeno das relações econômicas ${ }^{114}$. Veremos agora que o conceito ampliado do político, sugerido por Marx, compreenderia o papel da luta de classes como etapas na realização histórica do trabalho, o que ficaria evidente na idéia de que o proletariado - a classe trabalhadora intrinsecamente relacionada à produção industrial - surgiria como a classe universal, o grande sujeito histórico e portador do processo de produção e reprodução da sociedade.

\section{II - O conceito do político como epifenômeno das relações econômicas}

No contexto de uma autoreflexão renovada da esquerda contemporânea, certamente a concepção do político em Marx continua sendo uma referência importante ${ }^{115}$. Não podemos deixar de sublinhar que Marx e Engels, ao tomarem de empréstimo da economia política

\footnotetext{
${ }^{112}$ Habermas, J. „Volkssouveränität als Verfahren”, op. cit., p. 618.

${ }^{113}$ Habermas, J. "Naturrecht und Revolution”, op. cit., p. 117-118.

${ }^{114}$ Habermas, J. Faktizität und Geltung, op. cit., p. 65.

${ }^{115}$ As críticas feitas a Marx por parte dos liberais, principalmente a partir de 1989, insistem em descartar de uma vez por todas a possibilidade de uma alternativa política no interior do marxismo. De acordo com Helmut Dubiel - para ficarmos com apenas um exemplo - a "intelligentzia ocidental (...) tem de entender que o modelo liberal de democracia constitui a referência de todas as futuras estratégias políticas". Dubiel, H. "Metamorfosen der Zivilgesellschaft und reflexive Modernisierung". In: Dubiel, H. Ungewißheit und Politik. Frankfurt/M, 1994, p. 93.
} 
argumentos com os quais denunciam a ordem do direito burguês como expressão jurídica de relações injustas, ampliaram ao mesmo tempo o próprio conceito do que seja o "político"116. Pois o político não estaria circunscrito pelas análises e fenômenos referentes à tradição jurídico-política burguesa, mas abrangeria fundamentalmente os processos sociais que residem na base econômica da sociedade. Por essa razão, a emancipação humana não deve ocorrer no interior do campo tradicional da política, como uma emancipação política, mas sim acontecer como emancipação social, como libertação das condições sociais desiguais e opressoras às quais estão submetidos os indivíduos. "Enquanto a revolução política emancipara juridicamente os cidadãos", lembra Habermas, "uma futura revolução proletária deve emancipar socialmente os homens"117. Pois "a revolução política”, nas palavras de Marx, “dissolve a vida burguesa em seus elementos sem que estes próprios elementos sejam revolucionados e submetidos à crítica. Ela está relacionada à sociedade civil, ao mundo das necessidades, do trabalho, dos interesses privados, do direito privado, como a base de sua existência, como um pressuposto não plenamente fundamentado, e assim como sua base natural" ${ }^{\text {118 }}$. Em outras palavras, a emancipação política (que resultou da Revolução Francesa) significava apenas a emancipação das restrições políticas impostas pelo feudalismo: "O homem, portanto, não se libertou da religião; ele obteve liberdade de religião. Ele não se libertou da propriedade; ele obteve liberdade de propriedade. Ele não se libertou do egoísmo do mercado; ele obteve liberdade de mercado" ${ }^{119}$. Seria necessário, portanto, dar um passo além e vincular tal emancipação política parcial a uma posterior revolução social. Pois “apenas quando o indivíduo real (...) reconhecer e organizar suas forces propres como poder social, e por sua vez o poder social não se dividir mais na forma do poder político, apenas então a emancipação humana será consumada" ${ }^{\prime 20}$.

Provavelmente essa ampliação do conceito do político é um dos passos mais importantes a serem mantidos por uma teoria com orientação emancipatória. A intuição fundamental de Marx na sua crítica da sociedade civil consistiria em mostrar que o problema da democracia e da liberdade não poderia ser sanado sem que também fosse solucionada a "questão social""

\footnotetext{
${ }^{116}$ Cf. Habermas, J. "Volkssouveränität als Verfahren”, op. cit., p. 617.

${ }^{117}$ Habermas, J. "Naturrecht und Revolution”, op. cit, p. 117. Cf. Hayek, F. "Was ist und was heißt , sozial'?". In: Hunold, A. (org.). Masse und Demokratie. Zürich/Stuttgart: Eugen Rentsch, 1957, p. 71-84.

${ }^{118}$ Marx, K. Die Judenfrage. In: Marx-Engels Werke. Band 1. Berlin: Dietz Verlag, 1961, p. 369.

119 Ibidem.

${ }^{120}$ Idem, p. 370.

121 “A noção central dizia respeito à 'questão social', diferentemente de uma mera preocupação com o liberalismo político, a liberdade, o radicalismo filosófico ou religioso, etc". Draper, H. Karl Marx's theory of revolution: The state and bureaucracy, op. cit., p. 97. Cf. também p. 117 e ss.
} 
um importante esforço de vincular uma análise sistemática da reprodução e autovalorização do capital, o movimento proletário e a luta por uma democracia política efetiva. Contudo, gostaríamos de investigar se a tendência de Marx a reduzir a interação política à instrumentalidade das relações de classe não o levaria a dissolver também o conceito ampliado do político nas determinações econômicas constitutivas da "questão social”.

Existem muitas possíveis interpretações sobre o desenvolvimento da teoria de Marx e o que poderia significar essa ampliação do conceito do político. Embora não pretendamos nos limitar a uma única interpretação, a proposta de Jean Cohen nos parece particularmente interessante como orientação geral de leitura por quatro razões ${ }^{122}$. Em primeiro lugar, a autora está reavaliando a concepção de emancipação em Marx com os olhos voltados à sua contemporaneidade e pretende contribuir para o desenvolvimento de uma nova teoria crítica da sociedade. Pois o que seria necessário agora diz respeito a uma nova reflexão teórica e uma nova interpretação da contestação social e da práxis política ${ }^{123}$. O conceito marxista de classe (bem como de sistema, totalidade e história) não possibilitaria mais um ponto de partida que permitisse "unificar, teórica e praticamente, a pluralidade de lutas e movimentos sociais na sociedade contemporânea" 124 . Em segundo lugar, não se trata de uma abordagem meramente externa aos textos, pois a autora trata os diferentes momentos e formulações da teoria de Marx, apontando nuances e contradições inerentes ao desenvolvimento teórico e às suas consequiências práticas. Em terceiro lugar, com base em argumentos já apresentados, Cohen avalia que a ampliação do conceito do político em Marx significaria paradoxalmente um estreitamento da política na teoria das classes. Haveria uma tendência em tratar os processos políticos e a dinâmica da luta entre as classes como meros epifenômenos das relações econômicas. É em função dessa tese mais geral de uma crítica feita ao paradigma produtivista de emancipação que vamos nos concentrar mais detidamente. Por fim, em quarto lugar, a autora desenvolve argumentos que já se encontravam em grande medida nos termos da crítica

\footnotetext{
${ }^{122}$ Nesse aspecto, Cohen se diferencia dos autores que identificam recortes e mudanças no desenvolvimento da obra de Marx a partir de uma abordagem mais "marxológica" no campo da epistemologia e da relação entre "lógica" e "ontologia". Cf. principalmente Althusser, L. Pour Marx. Paris: Librairie François Maspero, 1966; Giannotti, A. Origens da dialética do trabalho. São Paulo: Difusão Européia do Livro, 1966; Ruy Fausto. Marx - Lógica e política. Tomo I. São Paulo: Brasiliense, 1987. O recorte privilegiadamente político está presente na interpretação de Michael Löwy. A teoria da revolução no jovem Marx. Tradução de Anderson Gonçalves. Petrópolis: Vozes, 2002. Porém, onde este vê uma ampliação do conceito do político no desenvolvimento da obra do jovem Marx que leva à formulação da "auto-emancipação do proletariado", Cohen entenderá como uma redução diante da determinação do paradigma produtivista. Para uma visão de conjunto, ver novamente Draper, H. Karl Marx's theory of revolution: The state and bureaucracy, op. cit., e também seu Karl Marx's theory of revolution: The politics of social classes. New York/London: Monthly Review Press, 1978.

123 "A tarefa do teórico crítico consiste em aceitar a diversidade de identidades e de movimentos procurando ao mesmo tempo desenvolver um esquema teórico capaz de defender e promover a complementaridade potencial das lutas emancipatórias". Cohen, J. Class and civil society: The limits of Marxian critical theory, op. cit., p. xiii. ${ }^{124}$ Idem, p. xii.
} 
habermasiana implícita a Marx desde 1968, ao distinguir o âmbito de ação entre trabalho e interação $^{125}$. O núcleo do argumento na obra do próprio Habermas, como veremos adiante, consistiria em que a teoria da luta de classes e da práxis revolucionária de Marx restringiria o processo de formação reflexiva correspondente a tal práxis política à esfera da produção, ou seja, à dialética do trabalho.

\section{A determinação econômica da política na teoria das classes}

Cohen classifica os textos de Marx nos seguintes períodos: a crítica da sociedade civil anterior a 1844; a primeira crítica da economia política em 1844; a teoria do materialismo histórico; e a teoria sistêmica do desenvolvimento capitalista nos Grundrisse e no Capital, de 1857 a 1883. A autora mostra como cada um desses períodos poderia ser interpretado como uma tentativa de Marx em desenvolver soluções ou alternativas a problemas surgidos, sobretudo, já em sua Crítica da filosofia do direito de Hegel. A teoria das classes responderia a problemas surgidos em formulações prévias de sua crítica da sociedade civil. Vimos anteriormente que o resultado desse desenvolvimento na crítica madura de Marx implicaria uma dissolução sociológica dos princípios normativos que regulavam a democracia, na medida em que se assume a existência de um sistema único - o modo capitalista de produção - cuja lógica penetraria e estruturaria todas as esferas da vida. O livro de Cohen nos permite fazer um recuo necessário e traçar esse percurso em algumas das principais obras de Marx no qual este, privilegiando a economia política como objeto da crítica, não apenas teria compreendido a sociedade civil e o Estado como instituições meramente burguesas subordinadas aos imperativos de autovalorização do capital, como identificaria também as relações de classe diretamente com a lógica de reprodução capitalista. Da crítica da sociedade civil anterior a 1844 até seus textos tardios, aconteceria assim paradoxalmente uma gradativa redução ou estreitamento da dinâmica própria da práxis política, da dimensão da ação social em face da determinação do paradigma produtivista. Essa provável redução e modificação do conceito de práxis poderiam ser notadas nos diferentes períodos abordados por Cohen: Marx teria concebido tal conceito em seus primeiros textos como uma rica "interação política", a qual retornaria somente em seus chamados textos histórico-políticos posteriores; em 1844 tal

\footnotetext{
${ }^{125}$ Cf. Habermas, J. Erkenntnis und Interesse. Frankfurt/M, Suhrkamp, 1999, p. 59 e ss. A reelaboração de sua crítica a partir da distinção "sistema" e "mundo da vida" encontra-se em Habermas, J. Theorie des kommunnikativen Handels. Band 2. Frankfurt/M: Suhrkamp, 1981, p. 489 e ss. Cf. também Habermas, J. “Arbeit und Interaktion”. In: Habermas, J. Technik und Wissenschaft als “Ideologie”. Frankfurt/M, Suhrkamp, 1969.
} 
conceito passaria a significar principalmente "objetivação"; e nos textos tardios variaria por fim ainda entre "objetivação" e "luta de classes".

Para a compreensão do desenvolvimento político do jovem Marx, é fundamental partirmos da distinção hegeliana entre sociedade civil e Estado ${ }^{126}$. Em sua Crítica da filosofia do direito de Hegel, Marx incorporaria a formulação hegeliana da sociedade civil compreendendo-a como um sistema de necessidades organizado pela economia de mercado, por um sistema jurídico que assegurava liberdades civis, associações e corporações da administração pública ${ }^{127}$. Contudo, ele rejeita as versões liberais e hegeliana da liberdade política que restringiriam a formação política da vontade ao âmbito das instituições do Estado por significar uma "alienação política". Isso porque Hegel procurou superar a fragmentação e desintegração resultante do princípio de autodeterminação abstrata e egoísta que regia a sociedade civil ao sublinhar a vinculação dos indivíduos a âmbitos do Estado em que se privilegiariam os interesses gerais sobre os particulares, gerando formas fundamentais de solidariedade social, tais como as corporações, a administração racional da justiça e a polícia $^{128}$. Não estava em questão na solução hegeliana a participação política ativa, pois a função das "corporações" consistia em garantir a integração social, mediando o Estado com os indivíduos essencialmente privatizados da sociedade civil. Em vez da participação democrática e de uma teoria da esfera pública, Hegel ocupou-se da Sittlichkeit, da "eticidade", da efetividade das normas, valores e costumes que permitiam a integração social ${ }^{129}$.

Segundo a visão de Marx, argumenta a autora, o problema do sistema hegeliano das corporações e do Estado consistia no fato de não dar conta dos princípios imanentes à sociedade civil explicitados pelo próprio Hegel: “A estabilidade alcançada por meio da institucionalização das associações voluntárias como corporações e que requeriam o reconhecimento do Estado (...) fatalmente solapa a independência da sociedade civil, cujos princípios são a individualidade, livre associação e auto-organização" ${ }^{\text {130 }}$. Tratar-se-ia de uma "crítica imanente" das pretensões normativas articuladas por Hegel entre sociedade civil e Estado, embora com a recusa de sua separação. Em outras palavras, não se tratava de afirmar

\footnotetext{
${ }^{126}$ Sobre a recepção da filosofia do direito de Hegel no jovem Marx, ver Draper, H. Karl Marx's theory of revolution: The state and bureaucracy, op. cit., p. 32 e ss.

${ }^{127}$ Cf. Hegel. Grundlinien der Philosophie des Rechts. Frankfurt/M: Suhrkamp, 1986, §§182-256.

${ }^{128}$ Cf. idem, op. cit., $\S \S 230-256$.

129 Cf. Habermas, J. Strukturwandel der Öffentlichkeit, op. cit. Também Honneth, A. Sofrimento de indeterminação: Uma reatualização da filosofia do direito de Hegel. Tradução de Rúrion Soares Melo. São Paulo: Esfera Pública, 2007, parte III. Contudo, Honneth não acredita que o papel da Sittlichkeit na filosofia do direito de Hegel estava limitado ao problema da integração social, mas sim às condições necessárias de realização da liberdade que poderiam ser reconstruídas normativamente.

${ }^{130}$ Cohen, J. Class and civil society: The limits of Marxian critical theory, op. cit., p. 28.
} 
o elemento de atomização dos indivíduos na sociedade civil contra o Estado, mas sim denunciar este Estado como um falso universal ou falsa totalidade, isto é, falsa solução para a fragmentação da sociedade civil já entrevista por Hegel. Diferentemente de sua crítica madura à sociedade civil, como já vimos, a tarefa da crítica do jovem Marx nesse texto consistiria em extrair as normas das instituições políticas modernas e contrastá-las com a forma institucional particular do Estado burguês que as realizariam apenas em parte (ou seja, realizaria apenas parcialmente a liberdade e a igualdade, a justiça e a democracia, etc). "A crítica imanente", de acordo com Cohen, "consiste em um projeto duplo: (1) tematizar e abrir à discussão aqueles princípios normativos inerentes às estruturas políticas modernas que deveriam informar a práxis social e política; e (2) demonstrar as constrições institucionais que impediam sua atualização na sociedade moderna (crítica da dominação e da estratificação)"131. É fundamental no argumento de Cohen o fato de que pensar a sociedade civil não implicava vincular o sistema das necessidades com aquilo que constituirá sua anatomia nos textos posteriores, a saber, o trabalho e o modo de produção capitalista. Uma vez que Marx ainda não havia reduzido a sociedade civil e o Estado às determinações da economia, ele teve de fazer uma crítica imanente que extraísse os princípios normativos das democracias modernas e contrastá-los com aquelas instituições que impediriam sistematicamente a realização de seus princípios. "Democracia" significaria, de acordo com a explicação de Hal Draper, "a união do Estado com o povo. Ela conota uma sociedade em que a separação entre o social e o político é transcendida, em que o universal e o particular não mais se opõem, em que o Estado não se encontra mais alienado da sociedade civil, e, por sua vez, esta sociedade civil não é mais meramente a esfera do interesse individual" ${ }^{, 132}$. Pela primeira vez, diz Marx, é possível com a democracia "a verdadeira unidade do universal e do particular", 133.

É ainda mais importante notar o fato de que a qualidade humana mais fundamental, ou seja, a práxis, seria localizada por Marx no interior da sociedade política. Marx entenderia tal práxis como uma capacidade de autodeterminação política por meio da interação com os outros em razão dos interesses da comunidade. A participação dos indivíduos na vida política - e não o trabalho, que será constitutivo a partir dos Manuscritos de 1844 - seria a verdadeira

\footnotetext{
131 Idem, p. 29. Esse sentido de crítica imanente formulado por Cohen, embora esteja ligado à crítica da sociedade civil, difere daquele de Lohmann tratado no início da primeira seção do presente capítulo devido ao valor posicional ocupado pela crítica da economia política no desenvolvimento da obra tardia de Marx. Cf. Lohmann, G. “Gesellschaftskritik und normativer Maßtab. Überlegungen zu Marx”, op. cit., p. 241-252.

${ }^{132}$ Draper, H. Karl Marx's theory of revolution: The state and bureaucracy, op. cit., p. 86.

${ }^{133}$ Marx, K. Kritik des Hegelschen Staatsrechts. In: Marx-Engels Werke. Band 1, op. cit., p. 231.
} 
expressão de sua humanidade ${ }^{134}$. Na medida em que o Estado moderno emerge com suas instituições políticas pretensamente universais (parlamento, burocracia, exército, polícia, tribunais, etc.), mantém-se uma estratificação social e, por conseguinte, reforça-se uma esfera de indivíduos apolíticos, unidos apenas pelas necessidades e interesses privados e que dependem mutuamente da divisão do trabalho e do mercado. À sociedade civil delega-se não um espaço de autodeterminação, de atividade autônoma, mas de alienação política própria de um individualismo irrestrito. Podemos notar que não haveria nessa formulação do jovem Marx uma consideração meramente funcionalista dos princípios normativos da república democrática, tal como vimos anteriormente em outros textos, pois as idéias de soberania popular, autonomia, igualdade, democracia, etc., possibilitariam a realização justamente dessa autodeterminação política - e que, na visão contemporânea de Cohen, seria fundamental ainda hoje para "instruir os movimentos sociais contra a exclusão e a igualdade política"135.

O que definiria, além disso, a inclusão da questão do social em seus primeiros escritos reside na constatação de Marx de que haveria na própria sociedade civil uma estratificação primária que adotava uma forma de dominação apolítica, ou seja, que não se mostrava na sua articulação nos modos de representação no interior do Estado. A posse ou falta da propriedade e a liberdade ou a necessidade de exercer trabalho assalariado já seriam os fatores determinantes de sua análise de classe no interior da sociedade civil. Marx identificaria assim uma classe de trabalhadores assalariados que, apesar de seu papel central para a reprodução econômica da sociedade, seria excluída de todos os benefícios materiais alcançados e, não obstante, veria também seus direitos serem sistematicamente violados. Mais uma vez, seria importante notar que, nesse texto, a superação dessa estratificação social ocorreria por meio de uma práxis de autodeterminação que incluísse as necessidades dessa classe na demanda política da sociedade. Porque a satisfação universal das necessidades poderia ser efetivada por meio da plena soberania popular, Marx defenderia a participação de todos na vida política, pois as questões do Estado, por natureza, concernem a todos: "A tendência da sociedade civil de se transformar em sociedade política ou de fazer da sociedade política a sociedade real, mostra-se como a tendência mais universal possível à participação no poder legislativo"136. Nesse caso, a crítica não apenas da separação entre Estado e sociedade, mas também da propriedade seria essencialmente política, ou seja, estaria fundada na determinação da

\footnotetext{
${ }^{134}$ Cf. Rundell, J. Origins of modernity. The origins of modern social theory from Kant to Hegel to Marx, op. cit., p. 84 e ss.

${ }^{135}$ Cohen, J. Class and civil society: The limits of Marxian critical theory, op. cit., p. 33. Essa também é a leitura de Behre, J. Volkssouveränität und Demokratie: Zur Kritik staatszentrierter Demokratievorstellungen. Hamburg: VSA, 2004, embora o autor mantenha tal interpretação inclusive para as obras maduras de Marx.

${ }^{136}$ Marx, K. Kritik des Hegelschen Staatsrechts, op. cit., p. 324.
} 
propriedade como critério excludente da vida política: tratar-se-ia de sublinhar o acesso à participação (“a mais universal possível”) e o possível controle democrático sobre os poderes do Estado.

Contudo, o que caracterizaria uma sociedade civil individualista seria antes o fato de ser motivada somente no interesse, o qual significaria a expressão da alienação a uma necessidade específica subordinada ao capitalismo ${ }^{137}$. Apenas uma transformação radical das necessidades, ou seja, somente a abolição da estrutura dos interesses, libertaria os indivíduos da alienação burguesa. Desse modo, não haveria somente uma separação entre sociedade civil e Estado a ser superada pela autodeterminação política. Marx manteve da formulação hegeliana a idéia da sociedade civil como um modelo funcional de realização das necessidades, mas entendendo tal realização a partir de sua base material: "a sociedade, através de um sistema de necessidades, pode estabelecer e mediar um metabolismo com a

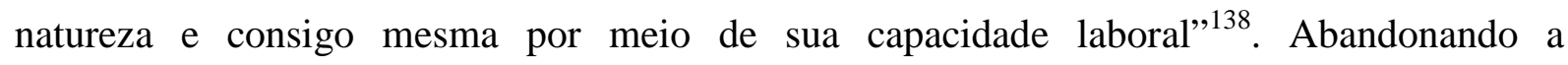
perspectiva da crítica imanente presente no livro de 1843, Marx buscaria uma determinação positiva capaz de superar o sistema de necessidades da sociedade civil, o qual seria deficitário não simplesmente da perspectiva política, mas sim do ponto de vista da dinâmica da vida material. A plena realização das necessidades radicais, a efetivação de valores que pudessem promover a abundância e o enriquecimento das capacidades individuais e coletivas, seria unificada em uma crítica materialista baseada em uma noção de criação da vida material, a qual, mesmo sendo entendida como uma atividade de autocriação humana, perderia o caráter imediatamente político de sua autodeterminação ${ }^{139}$.

A partir da formulação de sua primeira crítica da economia política em 1844, Marx apresentaria o conceito de trabalho compondo seu referencial econômico (em que a atividade produtiva estaria estreitamente atrelada à forma histórica específica do trabalho assalariado) juntamente com uma noção mais filosófica de objetivação (um processo por meio do qual os indivíduos produzem materialmente e satisfazem suas diferentes e variadas necessidades) ${ }^{140}$. O processo de objetivação do trabalho permitiria entender, por um lado, o que seria a atividade essencial e universal do homem, uma atividade constitutiva da totalidade de sua "vida produtiva", ou seja, sua "atividade vital" como ser-genérico. Primeiramente, a "vida

\footnotetext{
${ }^{137}$ Cf. Neuendorff, H. Der Begriff des Interesses, op. cit., principalmente Parte 4.

${ }^{138}$ Rundell, J. Origins of modernity. The origins of modern social theory from Kant to Hegel to Marx, op. cit., p. 90.

${ }^{139}$ Cf. Heller, A. Theorie der Bedürfnisse bei Marx. Vsa, 1987, principalmente p. 85-107; e Fraser, I. Hegel, Marx, and the concept of need. Edinburgh University Press, 1998.

${ }^{140}$ Cf. Cohen, J. Class and civil society: The limits of marxian critical theory, op. cit., p. 68-77. Cf. também Marcuse, H. "Sobre os fundamentos filosóficos do conceito de trabalho da ciência econômica". In: Marcuse, H. Cultura e sociedade I. Rio de Janeiro: Paz e Terra, 1998.
} 
genérica" consistiria nessa atividade produtiva para "a satisfação de uma necessidade, a necessidade de conservação da existência física"141. Além disso, o trabalho consistiria não apenas na expansão das necessidades físicas e orgânicas, mas também na condição de possibilidade da expansão das capacidades humanas e da própria liberdade: neste caso, o trabalho seria compreendido como atividade vital dos homens enquanto "ser-genérico consciente", como potencial de criação histórica de indivíduos que, na sua atividade laboral, constituiriam a totalidade de seus próprios produtos, suas relações sociais, sua cultura e instituições $^{142}$. Por outro lado, Marx procura sublinhar sobretudo as características do trabalho como trabalho alienado, como atividade heterônoma a que está submetido o homem: sob o julgo do capital, o trabalho transforma a atividade do indivíduo em um meio forçado de sobrevivência, o separa da coletividade, do seu ser-genérico, não permite que se reconheça no seu próprio produto e o sujeita à dominação de um sistema anônimo e independente de sua vontade, transformando-o em um não-homem, em proletariado ${ }^{143}$.

O conceito de ser-genérico foi concebido por Marx não diretamente a partir da filosofia do espírito do sistema hegeliano, mas segundo a crítica que Feuerbach fizera anteriormente a Hegel ${ }^{144}$. Porém, foi Marx quem pensou a realização do ser-genérico, a objetivação da vida da espécie, como a auto-objetivação coletiva dos produtores $\operatorname{associados}^{145}$. Seria, portanto, na passagem por seus Manuscritos de 1844 que Marx começaria a integrar no conceito de trabalho aquilo que compreenderia como uma atividade específica da classe trabalhadora, a saber, o trabalho como expressão da autodeterminação plena e simultaneamente como alienação. O proletariado passaria a ser interpretado como a única classe capaz de desenvolver necessidades radicais (o que o levaria a identificar, posteriormente, a realização de um sistema de necessidades radicais à constituição de uma sociedade de produtores associados ${ }^{146}$ ). A partir desse momento, Marx não apenas localizaria o proletariado como classe privilegiada pelo simples fato de esta exercer diretamente a atividade do trabalho e ser um pré-requisito do sistema capitalista, mas antes especificaria o problema da autonomia, da liberdade e da igualdade ao imputá-lo a uma classe universal, a

\footnotetext{
${ }^{141}$ Marx, K. Ökonomisch-philosophische Manuskripte (1844). In: Marx-Engels Werke. Band 40. Berlin: Dietz Verlag, 1990, p. 516.

${ }^{142}$ Cf. idem, p. 516-517.

143 Cf. idem, p. 510-522. Sobre o conceito de trabalho como objetivação e como trabalho alienado nos Manuscritos de 1844, ver Lange, E. Das Prinzip Arbeit, op. cit., capítulo 1.

${ }^{144}$ Cf. Lange, E. Das Prinzip Arbeit, op. cit., p. 93 e ss; e Giannotti, J. A. Origens da dialética do trabalho, op. cit., capítulo 1 .

${ }^{145}$ Cf. novamente Lange, M. Das Prinzip Arbeit, op. cit., p. 105-112.

${ }^{146}$ Cf. Heller, A. Theorie der Bedürfnisse bei Marx., op. cit., sobretudo o último capítulo.
} 
qual portaria o potencial emancipatório e se constituiria como fator determinante da abolição do próprio capital.

Esse passo no desenvolvimento da crítica de Marx denotaria um dos momentos mais significativos para o estabelecimento seguinte do paradigma produtivista como orientação emancipatória. O enfraquecimento do primado da política tornaria mais explícita a idéia de que a modernidade seria interpretada com base na sociedade do trabalho. A introdução de novas categorias críticas na interpetação do jovem Marx poderia ser entendida como uma colisão entre a lógica da economia (o que ainda não corresponderia à lógica dos modos de produção dos textos tardios) com a lógica da política, sendo que tal colisão o levaria a conceber a modernidade exclusivamente com base na reprodução funcional da esfera econômica ${ }^{147}$. Desse modo, o sistema das necessidades, o problema institucional da vida política e a autonomia dos indivíduos passariam a ser desmascarados como representações de uma realidade mais profunda, ou seja, o mundo do trabalho e da propriedade privada. Nessa nova chave conceitual, que Cohen nomeia de "crítica desmascaradora ou transcendente" "148, a atividade do trabalho (e não mais a autodeterminação política) forneceria um modelo de atividade humana capaz de explicitar os limites da ideologia economicista que compõe a sociedade civil. Como pensar então o conceito do político a partir de sua colisão com os imperativos do capital?

Como nota também Rundell, nos Manuscritos de 1844 Marx reconheceria o papel privilegiado do proletariado, "mas a classe trabalhadora apenas existe; ela ainda não age para se opor ou contestar os estragos da economia política" $"$. O esforço de superação da alienação teria de ocorrer com base em outra solução teórica e prática apresentada na sua Ideologia alemã, escrito juntamente com Engels. Ao proporem uma teoria do materialismo histórico, Marx e Engels fundamentariam sua teoria das classes (ou seja, o potencial revolucionário do proletariado) em uma análise científica da lógica da história. Porém, nessa nova formulação de sua crítica, os autores absolutizariam o ponto de partida da economia política estendendo as categorias da produção para a história passada e futura. Desse modo, "Marx coloca a 'história' no centro da discussão, substituindo a concepção estática do homo economicus, bem como a filosofia especulativa da consciência de si, levando em consideração as 'atividades reais' que constituem o movimento e o desenvolvimento das formações sociais - a

\footnotetext{
${ }^{147}$ Cf. Féher, F./Heller, A. "Class, modernity, democracy", op. cit., p. 211 e ss.

${ }^{148}$ Cohen, J. Class and civil society: The limits of marxian critical theory, op. cit., p. 36.

${ }^{149}$ Rundell, J. Origins of modernity. The origins of modern social theory from Kant to Hegel to Marx, op. cit., p. 101.
} 
produção"150. A história seria compreendida, portanto, segundo os distintos modos de produção pelos quais os homens produziriam não apenas seus meios de subsistência e necessidades, mas também suas relações sociais conscientes. Marx e Engels pressuporiam haver desde o início da história humana um vínculo materialista dos homens entre si que se desenvolveria independentemente de qualquer outra forma de organização coletiva (seja política ou religiosa, etc.) e que seria determinado pelas necessidades dos homens e seus respectivos modos de produção ${ }^{151}$. O trabalho continuaria sendo interpretado como a principal atividade que cria e forma a história. A novidade, contudo, consistiria no fato de que "o conceito de trabalho será reduzido agora à noção economicista e unilateral de produção (trabalho em geral), diante da qual o conceito filosófico de objetivação (e alienação) exercerá um papel subordinado" ${ }^{152}$.

O conceito de práxis política teria de ser pensado então a partir do desenvolvimento das forças produtivas de modo que tal desenvolvimento não se opusesse a uma teoria revolucionária da luta de classes. Para tanto, seria necessário identificar a autoatividade dos indivíduos e das classes com o próprio desenvolvimento das forças produtivas. "As forças produtivas", explica Habermas, "consistem (a) na força de trabalho aplicada na atividade de produção, dos produtores, (b) no saber tecnicamente utilizável, na medida em que pode se transformar em meio de trabalho capaz de aumentar a produção, em técnicas de produção, (c) no conhecimento organizacional, uma vez que tal conhecimento é adotado para tornar as forças de trabalho mais eficientes, para qualificar as forças de trabalho e para coordenar a cooperação dos trabalhadores na divisão do trabalho (mobilização, qualificação e organização da força de trabalho). As forças produtivas determinam o grau de disposição possível sobre a natureza",153.

Mas se, por um lado, as forças produtivas são criadas de modo a institucionalizar o metabolismo com a natureza e o processo evolutivo da humanidade (na agricultura, na manufatura, na revolução industrial), por outro lado, as formas de interação social, ou seja, as relações de produção, estabeleceriam as formas institucionais responsáveis por mediar os modos de cooperação (na família, nas formas de propriedade que passam a ser identificadas como formas de classe, no Estado, etc) ${ }^{154}$. Além disso, elas seriam instituições e mecanismos

\footnotetext{
${ }^{150}$ Cohen, J. Class and civil society: The limits of marxian critical theory, op. cit., p. 84.

${ }^{151}$ Cf. os quatro momentos das relações históricas originárias em Engels, F./Marx, K. Die Deutsche Ideologie, op. cit., p. 28-30.

${ }^{152}$ Cohen, J. Class and civil society: The limits of marxian critical theory, op. cit, p. 85.

${ }^{153}$ Habermas, J. “Zur Rekonstruktion des Historischen Materialismus”. In: Habermas, J. Zur Rekonstruktion des Historischen Materialismus, op. cit., p. 152-153.

${ }^{154}$ Cf. Marx, K. Die Deutsche Ideologie, op. cit., p. 22-23.
} 
que determinariam como a força de trabalho poderia ser combinada com os meios de produção disponíveis em um certo estágio do desenvolvimento das forças produtivas: "a regulação do acesso aos meios de produção (...) determinam indiretamente a distribuição da riqueza social. As relações de produção são uma expressão da distribuição de poder - elas determinam o padrão distributivo das oportunidades socialmente reconhecíveis para a satisfação das necessidades e a estrutura de interesses existentes na sociedade"155.

No contexto de seu materialismo histórico, a força motriz da história residiria no conflito entre forças produtivas e relações de produção: toda nova configuração social que emergiria na história resultaria da contradição entre as forças produtivas - que se instituíram da forma mais desenvolvida possível em um dado estágio da evolução histórica - e suas respectivas (porém insuficientes) relações de produção. O próprio antagonismo entre as classes seria a expressão dessa contradição. Esse movimento da história teria levado inexoravelmente ao capitalismo, o qual seria concebido como um estágio em que um imenso desenvolvimento das forças produtivas colidiria com os limites impostos pelas relações capitalistas de produção (trabalho assalariado e propriedade privada), levando finalmente à abolição da dominação de classe e ao posterior desenvolvimento da produção. Desse modo, a superação do capitalismo estaria fundada na possibilidade de desenvolvimento e reapropriação coletiva das forças produtivas.

Esse texto representaria um momento paradigmático no qual Marx passaria a perseguir a utopia de uma sociedade do trabalho ${ }^{156}$. "Chegou enfim", dizem Marx e Engels, “o momento em que os indivíduos devem se apropriar da totalidade das forças produtivas existentes a fim de atingirem a autoatividade (...) A apropriação dessas forças não é mais do que o desenvolvimento das capacidades individuais que correspondem aos instrumentos materiais de produção. (...) Só nesse nível a autoatividade coincide com a vida material, o que corresponde ao desenvolvimento dos indivíduos totalizados e à eliminação de todo crescimento natural" ${ }^{, 157}$. Ao romper com os entraves à expansão das necessidades, da produção e das capacidades de autorealização, o capitalismo criaria as condições para a universalização das necessidades - embora sua plena realização se encontrasse bloqueada em condições de trabalho heterônomo, ou seja, sob as relações de produção capitalista. A revolução corresponderia à transformação do modo de produção que, por meio de uma revolução social, resultaria em um produto social coletivo. O importante a partir desse

\footnotetext{
${ }^{155}$ Habermas, J. "Zur Rekonstruktion des Historischen Materialismus”, op. cit., p. 153.

${ }^{156}$ Cf. Rundell, J. Origins of modernity. The origins of modern social theory from Kant to Hegel to Marx, op. cit., capítulo 5; e Cohen, J. Class and civil society: The limits of marxian critical theory, op. cit., capítulo 3.

${ }^{157}$ Engels, F./Marx, K. Deutsche Ideologie, op. cit., p. 67-68.
} 
momento consistiria em frisar que "as lutas por emancipação podem agora ser travadas em nome das legitimações internas do próprio capitalismo: universalidade, desenvolvimento e satisfação" ${ }^{158}$.

Contudo, a visão de uma sociedade futura orientada para a satisfação de necessidades que poderia se expandir indefinidamente - porém baseada apenas em uma crescente produtividade - seria paradoxalmente uma projeção de significações e características capitalistas para o futuro: haveria uma tendência em assimilar a lógica da revolução proletária ao modelo revolucionário levado a cabo pela burguesia, pois seu fim último residiria no desenvolvimento posterior das forças produtivas iniciado pela burguesia. Ao reduzir as relações sociais às relações econômicas, segundo Cohen, sua "teoria das classes nunca pôde romper com o espelho da produção" e, portanto, acabaria por limitar o potencial da ação humana exatamente como o fez a sociedade capitalista a que Marx se opôs: "É irônico que Marx atribua ao proletariado a essência idêntica à qual a sociedade burguesa tentou reduzí-lo - força de trabalho. Definida segundo a universalidade da força de trabalho e baseada na lógica racionalista típica da consciência 'burguesa', a classe dos proletários, para ser consistente, tem de assumir a tarefa iniciada pela burguesia - a finalidade da produção e sua racionalização" 159 . Ao interpretar a crítica da economia política como um "espelho da produção", Jean Baudrillard acredita que "um espectro ronda o imaginário revolucionário: ele alimenta por todos os lados um romantismo desenfreado da produtividade" 160 . Pois "o pensamento crítico do modo de produção não atinge o princípio da produção. Todos os conceitos que se articulam nesse pensamento descrevem somente a genealogia, dialética ou histórica, dos conteúdos da produção, deixando intacta a produção como forma. É esta própria forma que ressurge idealizada como pano de fundo da crítica do modo de produção. Esta, com efeito, apenas reforça, por um curioso contágio, o discurso revolucionário em termos de produtividade (...) A palavra de ordem é a de um Eros produtivo. Riqueza social ou linguagem, sentido ou valor, signo ou fantasma, não há nada que não seja 'produtivo' segundo um 'trabalho'. Se essa é a verdade do capital e da economia política, ela é inteiramente incorporada por sua vez pela revolução: é em nome de uma produtividade autêntica e radical que se pretende subverter o sistema de produção capitalista. É em nome dessa hiperprodutividade desalienada, de um hiperespaço produtivo, que se pretende abolir a lei capitalista do valor. O capital desenvolve as forças produtivas, mas também as freia: é preciso

\footnotetext{
${ }^{158}$ Cohen, J. Class and civil society: The limits of marxian critical theory, op. cit., p. 73.

${ }^{159}$ Idem, p. 102.

${ }^{160}$ Baudrillard, J. Le miroir de la production. Ou, l'illusion critique du matérialisme historique, op. cit., p. 9.
} 
libertá-las" ${ }^{\prime 61}$. Nesse sentido, a atividade e a luta política dos trabalhadores - que teriam de ser entendidas antes como luta contra a racionalidade capitalista produtivista, como criação de formas de organização e demandas que expressariam necessidades radicais por novas formas de vida e novos valores que pudessem se apresentar como uma alternativa à dominação presente - permaneceriam atreladas ao modelo de classe burguês, repondo na práxis proletária aspectos da realidade que a burguesia havia antes criado para si mesma.

Somente em seus textos históricos (chamados também de textos políticos) seria possível romper, de alguma forma, com o paradigma produtivista. Embora, ainda assim, os textos sejam perpassados por uma justaposição de dois modelos de atividade política e revolucionária: uma análise que identificaria um constante processo na qual a dinâmica política envolve uma complexa mistura de necessidades (não diretamente ligadas à objetivação), tradição e símbolos, por um lado, e o cálculo racional do interesse de classe que penetra a dinâmica complexa do jogo político, por outro lado. Desse modo, Marx confrontaria seu rico processo de análise dos acontecimentos políticos nesses textos com um esquema interpretativo que resultaria reducionista. Apesar disso, nos escritos histórico-políticos surgiria uma noção de luta política e de história bem diferente daquela do materialismo histórico apresentado na Ideologia alemã: "A tradição, os mitos, uma compreensão não reducionista dos símbolos e da ideologia, da ação revolucionária e da política não determinada pelos interesses meramente econômicos, mas motivada por uma pluralidade de

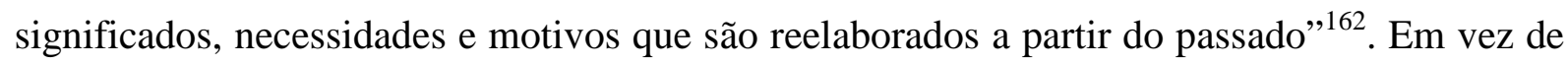
reconhecer os processos políticos e acontecimentos históricos como interesse de classe diretamente determinado pelo paradigma da produção, as rupturas radicais seriam motivadas por um conjunto de necessidades, valores, tradições, aspirações utópicas, etc., que ressurgiriam de um passado sempre por se completar em novas combinações e novos significados, mantendo em aberto a determinação do sentido da emancipação ${ }^{163}$.

Também Rundell acredita que os textos histórico-políticos ofereceriam um paradigma alternativo baseado na ação social de classe. Tal como Cohen, o autor entende ser possível resgatar, de uma perspectiva sociologicamente mais rica, as intuições presentes na crítica de Marx à filosofia do direito hegeliana de $1843^{164}$. Textos como A luta de classes na França, $O$ 18 Brumário de Louis Bonaparte e A guerra civil na França indicariam "um movimento

\footnotetext{
${ }^{161}$ Idem, p. 9-10.

${ }^{162}$ Cohen, J. Class and civil society: The limits of marxian critical theory, op. cit., p. 113.

${ }^{163}$ Cf. Draper, H. Karl Mar's theory of revolution: The politics of social classes, op. cit., principalmente parte II.

${ }^{164}$ Cf. Rundell, J. Origins of modernity. The origins of modern social theory from Kant to Hegel to Marx, op. cit., p. 149.
} 
implícito para além da noção de produção como uma forma básica e/ou total de ação social”, na qual os grupos em conflito "não derivam sua posição ou definição social do modo capitalista de produção"165. Encontraríamos nesses textos uma análise da nova tipologia do conflito e dos processos de decentralização e pluralização dos centros de poder. Além disso, a análise de Marx do período revolucionário francês e do Estado bonapartista apontaria para uma possível reinclusão das diferentes lógicas de desenvolvimento da modernidade não determinadas unilateralmente pela lógica capitalista. Nesses textos estaria incluída também a lógica da política, ou seja, da democracia e do Estado moderno. Rundell insiste especialmente no tratamento de Marx à dimensão da democracia, ao direito universal de participação política (incluindo o sufrágio universal) e à questão da soberania e da autonomia. A emancipação poderia ser concebida como um potencial radical incrustado na organização democrática da vida política, na democratização radical caracterizada pela emergência de "espaços públicos e instituições criticamente orientados, tais como a imprensa, os clubes (...) a Assembléia Nacional, os comitês e associações de trabalhadores formados durante o período da Comuna de Paris", etc ${ }^{166}$.

Cohen nota, porém, que "o que Marx oferece com uma mão, ele tira com a outra"167. A brilhante análise e descrição que remete à importância dos símbolos e tradições do passado, que se mesclavam com uma pluralidade de necessidades, interesses e idéias, e que compunham em conjunto a motivação da práxis política histórica, é diluída pela avaliação de Marx de acordo com a qual tal processo não seria impulsionado senão por uma "grande ilusão" que obscurecia a consciência revolucionária. Ao interpretar tais acontecimentos, ele procuraria "desmistificar as ilusões, mitos e tradições incessantes que ainda pesavam sobre a consciência dos atores (...) e que ocultavam suas relações e interesses de classe. Na verdade, o ponto de referência consiste no ideal de uma revolução proletária verdadeiramente universal que se realizaria unicamente em nome de um interesse de classe que pela primeira vez representa o interesse de toda a sociedade e, portanto, não necessita escrever sua poesia a partir do passado"168. Essa dificuldade em confrontar o paradigma produtivista com o paradigma da ação social também foi notado por Rundell. Pois ainda que a sociologia crítica de Marx nesses textos fosse sensível à dinâmica do conflito em toda sua extensão, lançando mão também da dimensão simbólica para analisar o embate entre diferentes centros de poder, por outro lado "a noção identitária e mitológica de classe (...) também continua presente e

\footnotetext{
${ }^{165}$ Idem, p. 150.

166 Idem, p. 159.

${ }^{167}$ Cohen, J. Class and civil society: The limits of marxian critical theory, op. cit. p. 114.

${ }^{168}$ Idem, p. 115.
} 
empurra a análise de volta à esfera da produção da qual emerge em Marx a lógica do conflito de classe" $" 169$. O lugar de Bonaparte na história e a lógica do conflito em torno do Estado durante o período revolucionário na França, no final das contas, seria avaliado segundo a representação do interesse dos pequenos proprietários. "Com isso", insiste Rundell, “o modelo da base/superestrutura permanece essencialmente intacto com seus imperativos da produção e sua antropologia do trabalho" ${ }^{\prime 170}$.

Seria apenas no Capital, na formulação madura de sua crítica da economia política, que Marx concluiria a substituição de sua crítica imanente da sociedade civil, com base na práxis de autodeterminação política, por uma crítica baseada no conceito de modo de produção. Segundo Cohen, a teoria da evolução histórica materialista daria lugar agora a uma análise das formações sociais que parte de uma distinção entre "lógica e gênese histórica" " Com esta distinção, seria possível apresentar pela primeira vez a economia como uma totalidade sistêmica cuja lógica é fundamental para a reprodução das relações sociais. Por um lado, os imperativos do processo específico de autovalorização do capital criariam uma subordinação total dos indivíduos à economia. Com isso, não apenas as raízes da alienação, mas também a própria constituição privilegiada da identidade de classe do proletariado residiria unicamente no modo de produção capitalista ${ }^{172}$. No que diz respeito à concepção de práxis em causa, porém, ao vincular estreitamente o conceito de classe ao modo de produção capitalista, a riqueza da crítica madura da economia política representaria ao mesmo tempo um estreitamento se comparada com a crítica imanente da sociedade civil: no Capital, "a relação com a práxis é somente determinista e arbitrária"173.

Ora, se as classes e as lutas entre as classes são constituídas pela lógica reprodutiva do capital, se o proletariado é fundido, homogeneizado e posto pelo próprio capital como um momento de seu próprio processo de valorização, se essa lógica impõe uma estrutura de interesses sobre as necessidades individuais daqueles que participam como agentes da produção, "em que base se pode argumentar", pergunta Cohen, "que a autoconstituição desses agentes da produção em uma classe que se opõe ao capital pode ser algo a mais do que a

\footnotetext{
${ }^{169}$ Rundell, J. Origins of modernity. The origins of modern social theory from Kant to Hegel to Marx, op. cit., p. 157.

${ }^{170}$ Idem, p. 165.

${ }^{171}$ Cf. Cohen, J. Class and civil society: The limits of marxian critical theory, op. cit., p. 43-44, 150 e ss. Cf. Giannotti, J. A. Origens da dialética do trabalho, op. cit., p. 182-194; e ver também Reichelt, H. Zur logischen Struktur des Kapitalbegriffs bei Karl Marx. Freiburg: ça ira, 2001, capítulo 3.

${ }^{172}$ Cf. a explicação de Draper em Karl Marx's theory of revolution II: The politics of social classes, op. cit., p. 33-48.

${ }^{173}$ Cohen, J. Class and civil society: The limits of marxian critical theory, op. cit. p. 50.
} 
afirmação subjetiva da lógica do próprio capital?" ${ }^{174}$. As lutas de classe que possibilitam o desenvolvimento das forças produtivas parecem levar adiante a lógica presente na produção capitalista, e não constituir uma práxis autônoma que contesta tal lógica de maneira radical. Pois, como se deixa ver em muitas passagens, "a barreira real à produção capitalista é o próprio capital" ${ }^{, 175}$. A única possibilidade de ação revolucionária apresentada no Capital consistiria na unificação do proletariado na base da socialização e da homogeneização do trabalho imanente ao processo de produção. Como representante das forças produtivas socializadas, como personificação do trabalho social, o interesse objetivo do proletariado teria de consistir na abolição dos limites impostos pelo capital ao posterior desenvolvimento das forças produtivas e sua organização consciente de acordo com um plano centralizado. A interação política perderia sua dinâmica própria, pois haveria uma dedução de uma lógica da luta de classes a partir da lógica de reprodução capitalista e das suas contradições imanentes: "As últimas implicações da integração do conceito de classe social em uma dinâmica da produção, da transformação das classes em personificação das relações de produção, em suma, da lógica do capital como uma lógica de luta de classes, se torna evidente logo que essa lógica do desenvolvimento interno e das contradições passam a ditar a dinâmica da constituição da classe e da transformação histórica"176. Pois, como confirmaria o próprio Marx no Capital, "o desenvolvimento histórico das contradições de uma forma de produção existente é a única via histórica de sua dissolução e de uma nova configuração" ${ }^{177}$.

Essa tese seria delineada, sobretudo, nas formulações de Engels sobre o socialismo científico e amplamente defendida nos círculos da ortodoxia marxista ${ }^{178}$. Segundo tais concepções, Marx teria descoberto a lei de desenvolvimento da história e mostrado que o desenvolvimento social estaria determinado por leis objetivas que levariam ao socialismo. Essa espécie de determinismo (chame-o de histórico ou de estrutural) se apresentaria como prognóstico científico sobre as transformações sociais resultantes do efeito de leis pretensamentes objetivas $^{179}$. Os processos formados e organizados pela troca de mercadorias

\footnotetext{
${ }^{174}$ Idem, p. 163.

${ }^{175}$ Idem, p. 174. Thomas Meyer desenvolve em seu livro a tese sobre uma possível ambivalência na teoria da emancipação de Marx, nomeando-a de o "dilema da inevitabilidade", em que o proletariado seria interpretado ora segundo sua capacidade de autodeterminação, ora segundo seu papel nas determinações estruturais. Cf. Meyer, T. Der Zwiespalt in der Marx'schen Emanzipationstheorie: Studie zur Rolle des proletarischen Subjekts. Kronberg, 1973. Problema semalhante foi tratado em Wellmer, A. Kritische Gesellschaftstheorie und Positivismus. Frankfurt/M: Suhrkamp, 1969, p. 77 e ss.

${ }^{176}$ Cohen, J. Class and civil society: The limits of Marxian critical theory, op. cit., p. 174.

${ }^{177}$ Marx, K. Das Kapital. Vol. I, op. cit., p. 512 (O grifo é nosso).

${ }^{178}$ Cf. Engels, F. "Die Entwicklung des Sozialismus von der Utopie zur Wissenschaft", op. cit, p. 215 e ss.

${ }^{179}$ Sobre a implicação do determinismo econômico para uma concepção marxista de história, ver Fleischer, H. Marxismus und Geschichte, op. cit., capítulo IV.
} 
levariam a resultados incompatíveis com o próprio processo de troca, produzindo assim uma incompatibilidade, ou seja, uma "contradição entre o desenvolvimento das forças produtivas e as relações de produção" ${ }^{180}$. Segundo a teoria do colapso do capitalismo, as crises econômicas se acirrariam a tal ponto que o capitalismo entraria em colapso devido às suas próprias contradições internas ${ }^{181}$. Essas tendências, que em longo prazo abalariam o sistema capitalista, consistiam, em suma, no aumento da taxa de exploração (criando a pauperização, absoluta ou relativa, do proletariado); no crescimento da composição orgânica do capital (o aumento do capital constante em relação ao capital variável, gerando o crescimento do exército industrial de reserva, significando aumento do desemprego); e, por fim, na teoria da crise econômica centrada no teorema de uma queda tendencial da taxa de lucro (ocorrendo a diminuição da acumulação do capital e da expansão da produção) ${ }^{182}$. Desse modo, o socialismo científico pretendia reconstruir o processo de autonegação do princípio de troca, o qual potencialmente seria o pressuposto da transformação revolucionária de toda superestrutura ideológica e política ${ }^{183}$.

O problema para o conceito do político consistiria no fato de que, segundo essa interpretação, o proletariado seria, portanto, um mero portador (Träger) das relações de produção. Esse determinismo parece ser bem exemplificado nas seguintes palavras de Kautsky: "Nós sabemos que nosso fim poderá ser alcançado apenas por meio de uma revolução, mas sabemos ainda com mais clareza que tampouco está em nosso poder fazer essa revolução como não está em poder de nossos opositores evitá-la. Não nos cabe absolutamente querer incitar ou preparar uma revolução" ${ }^{\text {184 }}$, uma vez que esta, podemos completar, estaria subordinada não à dinâmica conflituosa e constitutiva das relações de classe, mas antes à lógica de reprodução capitalista.

Uma das maneiras de evitar esse determinismo consistia em apreender o papel ativo do proletariado diante dos imperativos do sistema econômico. Contudo, as leis objetivas

\footnotetext{
${ }^{180}$ Berger, H. "Produktivkräfte und Produktionsverhältnisse“. In: Honneth, A./Jaeggi, U. (Org.). Theorien des Historischen Materialismus, op. cit., p. 257.

${ }^{181}$ Para uma visão de conjunto da teoria do colapso, ver Pannekoek, A. "The theory of collapse of capitalism". In: Capital and class, 1, 1977, p. 19-41. Cf. também Grespan, J. O negativo do capital: $O$ conceito de crise na política de Marx. Hucitec, 1998; Castells, M. A teoria marxista das crises econômicas e as transformações do capitalismo. Rio de Janeiro: Paz e Terra, 1979; e Mazzucchelli, F. A contradição em processo: O capitalismo e suas crises. São Paulo: Brasiliense, 1985.

${ }^{182}$ A "lei da queda tendencial da taxa de lucro" foi apresentada em Marx, K. Das Kapital. Vol. 3, op. cit., p. 221277. Cf. Rohlshausen, C. Kapitalismus und Krise. Eine Kontroverse um das Gesetz des tendenziellen Falls der Profitrate. Europäische Verlagsanstalt, 1970, principalmente p. 45-70; e Gillman, J. Das Gesetz des tendenziellen Falls der Profitrate. Europäische Verlagsanstalt, 1969.

${ }^{183}$ Cf. Engels, F. "Die Entwicklung des Sozialismus von der Utopie zur Wissenschaft”, op. cit., p. 219 e ss.

${ }^{184}$ Kautsky, K. Der Weg zur Macht. Frankfurt/M, 1972, p. 52. Essa citação, de 1893, se insere no período considerado o mais "revolucionário" de Kautsky.
} 
determinariam a ação do proletariado no processo de revolução social. Embora o conceito de forças produtivas tenha sido empregado após Marx por autores que procuraram superar o estreitamento economista do marxismo ${ }^{185}$, a interpretação mais comum consistiria em identificar as forças produtivas não apenas como "forças produtivas objetivas", ou seja, "meios de produção materiais". Nessa linha interpretativa, "a correspondência entre forças produtivas e relações de produção está relacionada aos meios de produção material (...) e a técnica se torna a 'base material' de toda organização social particular e, conseqüentemente, esclarece também a história da humanidade"186. Além disso, o próprio conceito de proletariado também é apresentado como "forças produtivas subjetivas"187, ou "forças produtivas do trabalho" ${ }^{188}$. Segundo a tese de Marx aludida acima, mesmo a pauperização progressiva que estaria em andamento antes do colapso do capitalismo fortificaria a consciência revolucionária dos trabalhadores e criaria também os pressupostos subjetivos para a transformação revolucionária ao socialismo ${ }^{189}$. Tudo leva a crer, portanto, que a "existência de classes está meramente relacionada a fases históricas particulares no desenvolvimento da produção" ${ }^{190}$. Desse modo, esses textos tardios outorgariam uma força revolucionária ao processo de trabalho de forma a permitir que o próprio processo de produção capitalista assumisse o papel de um meio de organização do proletariado. Apesar dos esforços de se manter a lógica política em sua colisão com a lógica econômica, ou seja, reservar o espaço de uma teoria da ação social de classe que atribuísse à dimensão da autodeterminação política o papel principal na configuração da emancipação (da autoemancipação do proletariado), parece que "a teoria como tal 'ignora' a ação das classes sociais"191. Pois, continua Castoriadis, no Capital as classes "sofrem a ação mais do que agem"192, uma vez que "determinismo econômico de um lado, luta de classes, de outro, oferecem duas maneiras de

\footnotetext{
${ }^{185}$ Marcuse o pensou como "arte” em Marcuse, H. Versuch über die Befreiung. Frankfurt/M: Suhrkamp, 1969, p. 47, 54, 71; Zur Lippe o pensou como "subjetividade" em Zur Lippe, R. Bürgerliche Subjektivität. Autonomie als Selbszerstörung. Frankfurt/M: Suhrkamp, 1975.

${ }^{186}$ Wildt, A. "Produtivkräfte und soziale Umwälzung", op. cit., p. 212.

${ }^{187}$ Marx, K. Grundrisse der Kritik der politischen Ökonomie, op. cit., p. 395.

${ }^{188}$ Idem, p. 215. Cf. entre outros Marx, K. Das Kapital. Vol. 1, op. cit., p. 331-355; Marx, K. Das Kapital. Vol. 3, op. cit., p. 835; e Marx, K. Lohn, Preis und Profit, op. cit., p. 127.

${ }^{189}$ Sobre a tese da paureização progressiva, ver Pannekoek, A. "The theory of collapse of capitalism”, op. cit., p. 27; e Wildt, A. "Produtivkräfte und soziale Umwälzung", op. cit., p. 214-215.

${ }^{190}$ Marx,K. Carta a Weydemeyer, 5 de maio de 1952. Citado a partir de Cohen, J. Class and civil society: The limits of Marxian critical theory, op. cit., p. 83.

${ }^{191}$ Castoriadis, C. A instituição imaginária da sociedade, op. cit., p. 27.

${ }^{192}$ Idem, p. 42.
} 
explicação irredutíveis uma à outra, e que no marxismo não existe verdadeiramente 'síntese', mas esmagamento da segunda em benefício da primeira"193.

Portanto, a crítica do Capital, em que o trabalho abstrato assumiria as caracterizações generalizantes da atividade humana, não poderia oferecer uma formulação de uma concepção de ação alternativa àquela completamente mercantilizada e reificada. A análise de Marx do "fetichismo da mercadoria"194 conduziria inevitavelmente a uma teoria unidimensional que aniquilaria a subjetividade humana, determinando a práxis nos termos de uma "totalidade funcional"195. Já chamamos atenção em nota anterior à tentativa de Lukács de oferecer uma concepção de totalidade como sujeito, procurando se livrar do estreitamento economicista da ortodoxia marxista. Mas ainda assim, como nota Habermas, seria preciso assumir que "Marx se apóia no argumento de que da posição objetiva da classe trabalhadora no processo de produção resulta uma concordância dos interesses particulares dessa classe com o interesse geral de todos os membros da sociedade. (...) Como a relação de classe entre capital e trabalho representa a estrutura básica dessa sociedade, a constelação de interesses da classe trabalhadora assegura até mesmo um acesso privilegiado ao conhecimento da sociedade

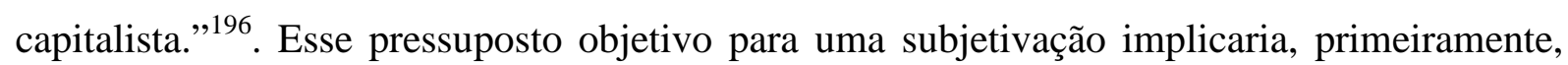
na determinação unilateral do sujeito político, uma vez que a reprodução funcional da sociedade do ponto de vista do proletariado repercutirá, como veremos, na posterior crítica à "total falta de referência para a própria política. Pois outras lutas emancipatórias não localizadas no âmbito da classe trabalhadora são negadas ou consideradas zonas de conflitos marginais"197. Além disso, como também teremos oportunidade de tratar no capítulo seguinte, sob as condições do capitalismo tardio, os interesses de classe seriam integrados em um sistema econômico-administrativo que passaria a substituir sistematicamente as questões da práxis pelas questões técnicas de uma sociedade autoregulada.

As considerações acima já nos remetem, por fim, ao ponto de partida da análise de Cohen sobre a teoria das classes, à perspectiva crítica com a qual a autora avaliaria os limites do conceito do político pensado como epifenômeno das relações econômicas, bem como a possibilidade de uma recepção contemporânea da Crítica da filosofia do direito de Hegel e de seus textos histórico-políticos. Os limites dessa concepção de práxis política revolucionária como orientação emancipatória consistiria, assim, na sua restrição para dar conta de uma

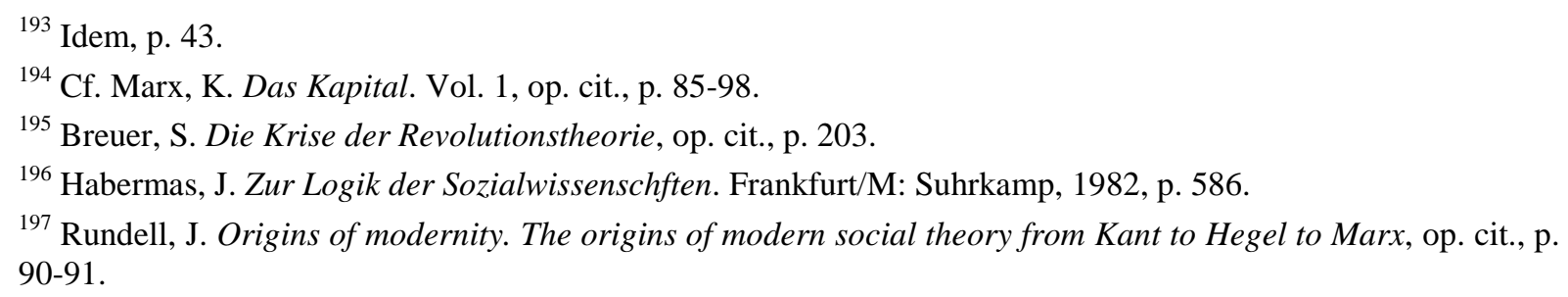


ampliação de demandas, atores, e questões a serem incluídos na agenda da esquerda contemporânea. A teoria das classes "exclui perigosamente a possibilidade (...) de poder haver outros modos de dominação que não as relações de classe sócio-econômicas, outros princípios de estratificação além de classe (nacionalidade, raça, status, sexo, etc.), outros modos de criação histórica e de interação que não o trabalho e a práxis revolucionária, outras fontes de motivação para a orientação da ação social, outras formas de interação política (participação) que não relações hierárquicas de poder, e outras maneiras de contestar a sociedade capitalista que não as lutas de classe em torno de necessidades radicais que emergem na dialética do trabalho",198.

Em contrapartida, segundo a autora, a posterior tipologia dos conflitos formulada nos textos políticos e principalmente o modelo do jovem Marx poderiam ser reatualizados contemporaneamente porque estavam centrados na realização radical da soberania popular por meio de um modelo de autodeterminação e interação política não circunscrito às relações econômicas: "Sem dúvida Marx permaneceu comprometido com os valores da liberdade pública, democracia, autonomia e igualdade, mas apenas em seus textos mais iniciais ele vislumbrou uma forma de democracia direta baseada no desenvolvimento posterior da sociedade civil, e não na sua abolição - uma forma que protegeria o indivíduo e o integraria na sociedade e no Estado por meio de sua própria participação ativa"199. Nesse contexto, a realização das necessidades radicais da comunidade política não estava limitada aos interesses privilegiados de uma única classe. Pois não poderíamos mais pressupor que os interesses de classe poderiam representar legitimamente todas as necessidades que compõem a pluralidade e complexidade da dinâmica política real. Adotando tarefa semelhante, Jürgen Behre entende que uma ampliação do conceito do político em Marx consistiria sim na radicalização da soberania popular parcialmente desenvolvida pelas filosofias políticas modernas. Porém, segundo o autor, não haveria contradição em pensar o proletariado como o sujeito histórico que realizaria essa superação em um processo de democratização que consistiria, em seu fundamento, em uma radicalização da soberania popular e da autodeterminação política ${ }^{200}$. O problema da interpretação de Behre residiria justamente na dificuldade de compreender a

\footnotetext{
${ }^{198}$ Cohen, J. Class and civil society: The limits of Marxian critical theory, op. cit., p. 193.

${ }^{199}$ Idem, p. 35.

200 “A emancipação humana implica submeter a parte da sociedade civil (...) a uma crítica a partir da perspectiva de sua superação prática. O modo desta superação prática, representada como processo de democratização, e que excede o horizonte político, não foi identificado por Marx até este momento da exposição. Ele será determinado agora como 'atividade crítico-prática revolucionária' e o proletariado será nomeado como sujeito desta atividade crítico-prática. A relação entre a crítica de Marx da república burguesa como forma acabada do Estado político, da propriedade privada como fundamento da sociedade civil e da crítica da dominação burguesa de classe tem de ser discutida com base no problema do proletariado". Behre, J. Volkssouveränität und Demokratie: Zur Kritik staatszentrierter Demokratievorstellungen, op. cit., p. 195-196.
} 
pluralidade das lutas políticas contemporâneas com categorias tais como "sujeito histórico" e "portador privilegiado da emancipação" sem excluir de antemão a maior parte daqueles concernidos em lutar e negociar os termos de sua própria emancipação que não se identificassem com o proletariado ou que não orientassem sua ação exclusivamente a partir de determinações das relações econômicas.

Diante desse problema - o qual, segundo nossa perspectiva, consistiria em partir necessariamente de Marx sem poder permanecer preso a ele - Cohen conclui que uma proposta como aquela oferecida pela teoria de Habermas representaria "a única alternativa ao perigoso mito de uma futura sociedade homogênea livre de conflito, na medida em que articula princípios que se referem a procedimentos de compromisso entre interesses conflitantes que surgem inevitavelmente em qualquer sociedade complexa" ${ }^{201}$. Seria preciso encontrar a possibilidade de ligar a práxis política a um processo de institucionalização no qual fosse possível entender as transformações sociais vinculando autonomia e reflexividade. Ora, porque possibilitou uma teoria que articula procedimentos no interior do processo político, "Habermas tornou possível mais uma vez a crítica imanente!"202. Desse modo, a crítica às determinações econômicas da política nos leva à avaliação do conceito estreito de práxis pressuposto na teoria das classes. E a análise habermasiana se torna frutífera para que possamos nos munir conceitualmente de modo a poder formular ao lado da ação baseada no trabalho uma dimensão reflexiva de atividade autônoma não determinada pela autoatividade produtiva.

\section{Trabalho e interação}

Por ficar preso ao contexto de nascimento do primeiro industrialismo, Habermas entende que a teoria de Marx se fixou naqueles fenômenos que se manifestavam dentro de uma sociedade do trabalho. Essa fixação ganhou contornos globais. Marx pretendeu apresentar categorias constitutivas de uma formação social sistemicamente desenvolvida em um certo tempo e derivar de tais categorias um padrão estrutural cuja lógica poderia ser remetida para formações sociais anteriores e posteriores ${ }^{203}$. Habermas não acredita que a

\footnotetext{
${ }^{201}$ Cohen, J. Class and civil society: The limits of Marxian critical theory, op. cit., p. 209.

202 Idem, p. 224.

203 "Hipóteses sobre o princípio organizacional de uma sociedade, sobre as capacidades de aprendizado e o campo de variação estrutural possível não podem ser clara e empiricamente testadas até que os desenvolvimentos históricos tenham colocado os limites críticos para tal teste. As análises do presente com orientação evolucionista esbarram sempre diante de um obstáculo, pois não podem observar seu objeto retrospectivamente.
} 
lógica do capital seja a chave para a lógica da evolução social em seu conjunto. Os problemas sistêmicos que emergem no processo capitalista de reprodução não poderiam ser atribuídos a todas as formações sociais anteriores. E para conceber o trabalho social como futura autorealização coletiva dos produtores associados, a assimilação do trabalho industrial teria de se transformar em um modelo normativo pleno de conteúdo, determinando decisivamente a diferenciação entre "a objetivação de forças essenciais e sua alienação, entre uma práxis satisfeita que retorna a si mesma e uma práxis fragmentada e paralisada"204.

O trabalho representaria o traço mais característico da espécie humana: "o trabalho", afirma Marx no Capital, "é primeiramente um processo entre homem e natureza, um processo por meio do qual o homem pode mediar, regular e controlar seu metabolismo com a natureza por meio de sua própria atividade. Ele se coloca diante dos próprios elementos naturais como produto. Ele emprega as forças naturais de seu próprio corpo, braços e pernas, cabeça e mãos, para se apropriar dos elementos naturais de uma forma útil para sua própria vida" ${ }^{205}$. Essa atividade primordial, que se inicia, segundo Marx, como um processo em que "o homem regula e controla seu intercâmbio com a natureza por meio de sua própria ação" ${ }^{206}$, configura o trabalho desde o início como "atividade com respeito a um fim",207 e que precisa incluir ainda "seu objeto e seu meio" 208 . Habermas acredita encontrar nessa atividade com respeito a um fim a característica principal do processo do trabalho para a espécie humana como reprodução da vida material segundo regras da ação instrumental: a atividade instrumental dos indivíduos estaria organizada, basicamente, para os fins da produção.

Além disso, também as regras da ação estratégica guiariam a coordenação social que seria um pressuposto fundamental do processo do trabalho. Nesse sentido, a distribuição dos produtos do trabalho seria socialmente organizada por meio de uma conexão sistemática de "expectativas ou interesses recíprocos",209, a qual ocorreria, segundo Habermas, por meio de

Por essa razão, teorias desse tipo - sejam marxistas ou não-marxistas - precisam monitorar suas hipóteses (que já são formuladas sob a delimitação e descrição do objeto) contra uma teoria instrutiva do desenvolvimento social. As caracterizações da sociedade contemporânea como industrial, pós-industrial, tecnológica, cientifífica, capitalista, sociedade de capitalismo-tardio, de Estado monopolista, de capitalismo de Estado, moderna, pósmoderna, etc. são retiradas de muitos modelos de desenvolvimento que vinculam a formação social presente com as anteriores. Nesse sentido, o materialismo histórico pode assumir a tarefa de determinar o princípio organizacional da sociedade contemporânea da perspectiva da emergência de sua formação social, ou seja, com formulações sobre s problemas sistêmicos que as sociedades tradicionais falharam em resolver e sobre as inovações com as quais a sociedade civil moderna lidou com as transformações evolutivas". Habermas, J. "Einleitung: Historischer Materialismus und die Entwicklung normativer Strukturen", op. cit., p. 41.

${ }^{204}$ Habermas, J. Der Philosophische Diskurs der Moderne, op. cit., p. 81.

${ }^{205}$ Marx, K. Das Kapital. Vol. 1, op. cit., p. 192.

${ }^{206}$ Ibidem (O grifo é nosso).

${ }^{207}$ Idem, p. 193 (O grifo é nosso).

208 Ibidem.

${ }^{209}$ Habermas, J. “Zur Rekonstruktion des Historischen Materialismus”, op. cit., p. 146. 
normas sociais de organização coletiva. Essa relação social primária que regula o trabalho e a distribuição de seus produtos consistiria na forma econômica de reprodução da vida, que Marx adotaria como a mais fundamental para o desenvolvimento da história da humanidade em seu conjunto. Segundo Marx e Engels, “a produção da vida, tanto da própria vida no trabalho quanto da vida dos outros na procriação, já parece se mostrar desde logo como uma dupla relação - de um lado, como relação natural, de outro lado, como relação social - , social no sentido de que se entende por ela a cooperação de diversos indivíduos, não importam suas condições, modos ou fim. Segue-se disso que um determinado modo de produção ou um determinado estágio industrial estão sempre unidos a um determinado modo de cooperação ou a um determinado estágio social, e este próprio modo de cooperação é uma 'força produtiva', a soma das forças de produção acessíveis ao homem condiciona o estado social e, portanto, a 'história da humanidade' deve ser estudada e elaborada sempre em relação com a história da indústria e da troca" ${ }^{210}$. Ambas as formas de produção e de cooperação estariam estabelecidas sobre uma dimensão reflexiva muito estreita para a reprodução histórica da vida humana, predominantemente centrada no trabalho.

José Arthur Giannotti analisa esse processo primário de trabalho no Capital tomandoo "numa dimensão operante imbricada noutra representativa. Desse modo, torna-se possível frisar o caráter reflexionante da produção como um todo" ${ }^{\text {211 }}$. Esse caráter reflexionante da produção resultaria da articulação inicial entre a autodeterminação da ação do sujeito sobre objetos e meios que, apesar de sua codeterminação, não impediriam que aquele passasse a "ter parte da natureza à sua disposição"212. Embora insista "nos limites dessa reflexão do trabalho", na medida em que sua atividade encontra a "barreira das coisas" e "estanca diante do produto que lhe escapa"213, Giannotti pretende entender o processo do trabalho como resultado de um processo reflexivo, como produto que é "ser-posto" sem se prender a algum princípio transcendental de tipo fichteano. O caráter reflexionante do trabalho, apesar da mediação entre forma e matéria, estabelece, primeiramente, o aspecto criador do sujeito sobre o objeto sempre como uma codeterminação por meio da qual está nas mãos daquele que exerce a atividade produtiva antecipar os fins de seu próprio trabalho sobre seu meio circundante. Essa relação flexível e metabólica inicial com a natureza conduziria, além disso,

\footnotetext{
${ }^{210}$ Engels, F./Marx, K. Deutsche Ideologie, op. cit., p. 29-30.

${ }^{211}$ Giannotti, J. A. Trabalho e reflexão. São Paulo: Brasiliense, 1983, p. 11.

${ }^{212}$ Idem, p. 87.

${ }^{213}$ Idem, p. 89.
} 
para formas de sociabilidade que abarcam o processo produtivo, de consumo e das relações sociais de produção ${ }^{214}$.

Habermas não conclui dessa relação entre homem e ambiente no processo do trabalho socialmente organizado que a suposta dimensão reflexiva que o articula se estenda decisivamente para além da "transformação do material orientada por um fim segundo regras da ação instrumental" ${ }^{215}$. A ação baseada no trabalho consistiria antes na autodeterminação posta no produto que constitui o processo do trabalho como autoatividade de um sujeito que controla a natureza a partir de sua própria ação, isto é, como atividade com respeito a um fim. $\mathrm{O}$ mecanismo de desenvolvimento da história da humanidade estaria limitado à ação racional com respeito a fins: com base na atividade produtiva e na cooperação social, a ação instrumental estaria diretamente imbricada pela ação estratégica na reprodução da vida humana. No interior da filosofia moderna, Marx deslocaria a dimensão reflexiva do modelo de um sujeito cognoscente para a práxis de um sujeito produtor como consequência do desenvolvimento das forças produtivas. Se naquele modelo as relações entre sujeito e objeto estavam fundadas em pretensões de validade assertivas, em que as opiniões sobre o mundo objetivo podem ser sucetíveis de serem verdadeiras, Marx desloca essa relação para a filosofia da práxis, sem alterar, acredita Habermas, o modelo do sujeito-objeto: "a filosofia da práxis, que privilegia a relação entre sujeito agente e o mundo dos objetos manipuláveis, concebe o processo de formação da espécie (segundo o modelo da autoexteriorização) como autoprodução. Considera não a consiência de si, mas o trabalho como princípio da modernidade" 216 . Diferentemente da explicação do trabalho primitivo e social oferecida por Giannotti, a dimensão reflexionante do trabalho não representaria algo diferente da ação de um sujeito agente que executaria com êxito atividades com respeito a fins para produzir algo no mundo objetivo.

Apoiando-se nos estudos antropológicos de Arnold Gehlen sobre a técnica, Habermas contrapôs à explicação produtivista o fato de que não apenas os homens, mas também os hominídeos se distinguiriam de outros animais por se reproduzir por meio do trabalho social e de uma economia: "Os machos adultos formavam grupos de caçadores que (a) dispunham de armas e ferramentas (técnica), (b) cooperavam por meio de uma divisão do trabalho (organização cooperativa) e (c) distribuíam sua caça com a coletividade (regras de distribuição) (...) Portanto, o conceito marxista de trabalho social seria útil para delimitar o modo de vida dos hominídeos diante daqueles dos primatas; mas não capturaria a reprodução

\footnotetext{
${ }^{214}$ Idem, capítulo V.

${ }^{215}$ Habermas, J. "Zur Rekonstruktion des Historischen Materialismus”, op. cit, p. 145.

${ }^{216}$ Habermas, J. Der Philosophische Diskurs der Moderne, op. cit., p. 80.
} 
especificamente humana da vida" 217 . O conceito de trabalho social seria fundamental porque, tal como o entende Habermas, a organização do trabalho e da distribuição precederia a emergência de relações simbólicas e reflexivas, que ocorreriam posteriormente pelas formas lingüísticas de comunicação. Mas o modo de vida especificamente humano teria de ser adequadamente caracterizado somente se acrescentássemos ao conceito de trabalho social alguma forma de organização coletiva regulada por determinadas regras. Em outros termos, as estruturas simbólicas que passariam a determinar os comportamentos dos indivíduos não ficariam mais atreladas àquelas do trabalho social. Segundo Habermas, essas estruturas simbólicas de interação coletiva, intersubjetiva, não poderiam mais ser reduzidas a ações instrumentais ou estratégicas. A produção e a socialização, o trabalho social e a estrutura parental, seriam assim ambos de igual importância para a reprodução da espécie humana: "Podemos falar de reprodução da vida humana alcançada com o homo sapiens apenas quando a economia da caça é substituída pela estrutura social familiar. Esse processo durou muitos milhões de anos; ele significa uma substituição não-trivial do sistema animal de status (...) por um sistema de normas sociais que pressupõe linguagem,"218.

Segue-se que a crítica da economia política de Marx apresentaria um recorte da história da humanidade voltado à reprodução da vida material coordenada socialmente para a realização coletiva e padronizada de fins, tais como a produção e a distribuição de bens e serviços, e a especificidade sistêmica de autovalorização do capital, aquilo que diferenciaria a economia capitalista no processo de evolução social. O sistema econômico, segundo Habermas, satisfaz justamente as condições de reprodução material por meio do dinheiro: este consistiria em um medium que, através de processos de abstração, se separaria das relações de vida estruturadas linguisticamente consolidando-se como um código especial para as situações de troca e que condicionaria as decisões sobre ações de uma maneira eficaz para a coordenação $^{219}$. O dinheiro possibilita formas de interação segundo um sistema parcial, mas especificamente funcional. Marx mostrou que, historicamente, surge com o capitalismo um sistema econômico que regula o intercâmbio de mercadorias e envolve seus entornos não econômicos, tais como a família e o Estado: este foi assimilado pelos imperativos de autovalorização do capital e as formas de vida tradicionais se dissolveram sob a forma do trabalho assalariado. É por essa razão que, posteriormente, "a revolução sobre a propriedade privada dos meios de produção deve atingir, ao mesmo tempo, os fundamentos institucionais

\footnotetext{
${ }^{217}$ Habermas, J. "Zur Rekonstruktion des Historischen Materialismus”, op. cit, p. 148-149.

${ }^{218}$ Idem, p. 150.

${ }^{219}$ Cf. Habermas, J. Theorie des komunikativen Handels. Vol. 2, op. cit., seção sobre desacomplamento entre sistema e mundo da vida, p. 229-293, e 395-400.
} 
do medium por meio do qual a economia capitalista foi diferenciada. Ela deve devolver sua espontaneidade ao mundo da vida enrijecido sobre o capital",220.

Embora Marx assumisse que o desenvolvimento das sociedades teria de poder ser localizado no desencadeamento das forças produtivas, as sociedades se desenvolveriam também por meio de um processo de aprendizado que abrangeria a dimensão de uma regulação simbólica e reflexiva de interação. Diante da filosofia da práxis e de seu modelo de ação baseada no trabalho, seria necessário entender essa dimensão simbólica com uma noção alargada de ação. Como explica Luiz Repa, "por ação não se entende somente a intervenção que podemos realizar no mundo das coisas, não se entende um 'fazer' (...) Por ação podemos entender também a realização de relações sociais em uma inter-ação. Dessa perspectiva, é preciso incluir a comunicação como elemento essencial da ação, já que nenhuma interação

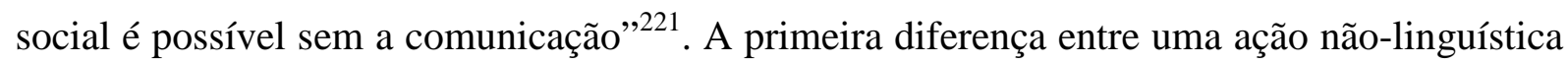
(como a atividade produtiva) e a interação consistiria no "traço reflexivo"222 desta última. Embora todas as ações possam ser apreendidas como ação com respeito a fins, tais ações, segundo a estrutura reflexiva da interação mediada pela liguagem, também não poderiam ser realizadas sem a cooperação e o assentimento livre de coerção dos participantes na interação e poderiam ser explicadas somente pelo recurso ao conceito de entendimento que habita no interior do próprio medium linguístico. Essas ações cooperativas são definidas por Habermas como processos de entendimento: "O entendimento linguístico funciona na medida em que os participantes na interação entram em acordo sobre a pretendida validade de seus atos de fala ou levam em consideração correspondentemente os dissenços constatados. Com os atos de fala, levantam-se pretensões de validade criticáveis que apontam para um reconhecimento intersubjetivo. Uma oferta contida no ato de fala obtém força obrigatória quando o falante garante, com sua pretensão de validade, que está em condições de resgatar essa pretensão com o tipo correto de razões, caso seja exigido" ${ }^{223}$. Desse modo, a ação estratética se distinguiria da ação comunicativa na medida em que a coordenação social não estivesse apoiada apenas na ação com respeito a fins, mas na força racionalmente motivadora dos atos de entendimento, ou seja, "em uma racionalidade que se manifesta nas condições para o acordo obtido comunicativamente" 224 .

\footnotetext{
${ }^{220}$ Habermas, J. Der Philosophische Diskurs der Moderne, op. cit., p. 408.

${ }^{221}$ Repa, L. "Jürgen Habermas e o modelo reconstrutivo de teoria crítica". In: Nobre, M. (org.) Curso livre de teoria crítica., op. cit., p. 166. (O grifo é nosso).

${ }^{222}$ Habermas, J. "Handlungen, Sprechakte, sprachlich vermittelte Interaktionen und Lebenswelt". In: Habermas,

J. Nachmetaphysiches Denken. Frankfurt/M: Suhrkamp, 1989, p. 65.

${ }^{223}$ Idem, p. 70.

${ }^{224}$ Ibidem.
} 
A distinção entre ação com respeito a fins e entendimento apóia a diferenciação, fundamental para a análise de sociedades modernas, entre as formas de integração sistêmicas e simbólicas ${ }^{225}$. Para Habermas, as sociedades modernas possuem uma estrutura de diferenciação complexa, contando com o mercado e o Estado como meios eficazes para implementar os fins da coordenação social. Mas além disso, a sociedade é explicada como mundo da vida estruturado simbolicamente. Podemos sintetizar os componentes do mundo da vida segundo a reprodução cultural (um estoque de saber a partir do qual os participantes em interações extraem suas interpretações no momento em que se entendem sobre algo); a integração social (ordens legítimas por meio das quais os participantes em interações regulam sua pertença a grupos sociais e garantem a solidariedade); e as estruturas da personalidade (motivos e habilidades que colocam um sujeito em condições de falar e agir, bem como de assegurar sua própria identidade em processos de socialização) ${ }^{226}$.

O modelo do sujeito-objeto pressuposto no conceito de trabalho também circunscreve a práxis à filosofia do sujeito, limitando assim o conceito intersubjetivo de ação e de razão prática àquele de disposição. Isso poderia ser notado a partir de dois pontos de vista. Primeiramente, a autoprodução consistiria na intervenção imediata do sujeito em relação ao mundo objetivo por meio de um processo cíclico de exteriorização, objetivação e apropriação $^{227}$. Mas não simplesmente restringindo tal processo à atividade de cada sujeito individual, mas também ao interpretar a sociedade como um macrosujeito: também a exteriorização, objetivação e apropriação consistiriam nas etapas constitutivas das determinações da comunidade de produtores associados que se libertariam das condições do trabalho heterônomo. Como explica Seyla Benhabib, "o propósito principal da teoria social crítica consiste em desmistificar o poder de dominação que se impõe sobre a vida dos indivíduos, e devolver o controle de suas ações e interações aos próprios indivíduos. Pretendese que os homens possam se 'reapropriar' de tudo o que eles mesmos criaram. Essa 'reapropriação' pode tomar duas diferentes formas: ela pode ser entendida como realização do potencial implícito do presente ou como transformação deste em favor de uma nova situação. A dificuldade central não reside nesses dois conceitos de emancipação, nem nas ambivalências que os acompanham. A dificuldade real reside no próprio conceito de 'reapropriação', ou seja, na epistemologia e na concepção política que implica. Com o conceito de 'reapropriação' o discurso marxista mais uma vez recai na filosofia do sujeito e

\footnotetext{
${ }^{225}$ Cf. Peters, B. Die Integration moderner Geselschaften. Frankfurt/M, Suhrkamp, 1993.

${ }^{226}$ Cf. Habermas, J. "Handlungen, Sprechakte, sprachlich vermittelte Interaktionen und Lebenswelt”, op. cit., p. 96-97.

${ }^{227}$ Cf. Lange, E. M. Das Prinzip Arbeit, op. cit., capítulos 1 e 2.
} 
nega o ponto de partida da intersubjetividade"228. Pois a dimensão social conflitiva não seria analisada a partir da capacidade de restituição material da autoatividade produtiva alienada (seja na forma do trabalho social e da produção cooperativa, ou simplesmente em termos de criação livre, etc). O ponto de partida intersubjetivo acentuaria antes os entraves da socialização em sua dinâmica com a individualização, da negociação dos diversos interesses individuais e coletivos, da solução dos conflitos de valores e a dimensão não apenas material, mas simbólica da satisfação de necessidades plurais, da legitimidade de princípios e normas de regulação social no campo da moral e do direito, etc.

Portanto, a sociedade se constituiria não apenas pela atividade produtiva, mas também por meio da interação, e esta não precisaria encerrar em si o trabalho, embora os indivíduos não possam existir sem trabalho, sem o qual não seria possível qualquer forma de sociedade. Porém, não poderíamos reconhecer a esfera da interação ao lado da esfera do trabalho caso partíssemos de uma teoria social voltada exclusivamente à reprodução material, caso a sociedade fosse "entendida como a base a partir da qual deve ser determinada toda a superestrutura, inclusive e estrutura da consciência e da comunicação linguística" ${ }^{229}$. Apenas poderíamos falar de uma relativa autonomia da interação diante da ação baseada no trabalho "se colocássemos de lado todo o paradigma produtivista e puséssemos no seu lugar o paradigma da comunicação" ${ }^{, 230}$. Este paradigma possibilitaria recuparar a dimensão reflexiva da cooperação social, uma vez que "só um processo de entendimento mútuo intersubjetivo pode levar a um acordo que é de natureza reflexiva" ${ }^{\text {231 }}$. Apenas fundamentando a práxis social de modo a distinguir a autonomia entre reflexão e trabalho, seria possível levar a termo a intenção de Marx em fundamentar uma teoria da emancipação a partir de uma distinção entre objetivação (uma práxis satisfeita que retorna a si mesma) e alienação (uma práxis fragmentada e paralisada).

É possível reconhecer que, na análise da mercadoria como força de trabalho, já estava presente de certa forma a distinção entre uma dimensão instrumental e outra supostamente reflexiva: o processo do trabalho poderia ser simultaneamente descrito segundo as ações concretas correspondentes, assim como segundo as operações abstratas, como trabalho abstrato. A força de trabalho despendida constitui uma categoria em que os imperativos de integração sistêmica coincidem com aqueles da integração social: como ação concreta, estaria

\footnotetext{
${ }^{228}$ Benhabib, S. Critique, norm and utopia., op. cit., p. 68.

${ }^{229}$ Tomberg, F. Habermas und der Marxismus, op. cit., p. 300.

${ }^{230}$ Ibidem.

${ }^{231}$ Habermas, J. "Diskursethik - Notizen zu einem Begründungsprogram". In: Habermas, J. Moralbewusstsein und kommunikatives Handeln. Frankfurt/M: Suhrkamp, 1983, p 77.
} 
ligada a contextos de cooperação; como ação meramente operacional e abstrata, estaria ligada ao contexto funcional da empresa capitalista e do sistema econômico. Provavelmente a força da crítica elaborada no Capital residiria em descortinar, por meio de uma exaustiva análise, não os momentos reflexivos da integração social, mas sim aquelas operações reificantes que constituem o trabalho abstrato e que submetem as ações concretas aos imperativos sistêmicos. "Marx explica esse processo de abstração real", nas palavras de Habermas, "como a coisificação (Versachlichung) dos contextos de ação integrados socialmente, que se realiza quando as interações já não são mais coordenadas segundo normas e valores, ou por meio de processos de entendimento, mas somente segundo o medium do valor de troca. Nesse caso, os participantes estão interessados fundamentalmente nas consequências de suas ações. E ao se orientarem por 'valores' segundo uma ação racional com respeito a fins, como se aqueles fossem objetos de uma segunda natureza, eles adotam uma atitude objetivadora em relação aos outros e consigo mesmos, transformando as relações sociais e intrapsíquicas em relações instrumentais,"232.

Porém, Marx não poderia entender a transformação do trabalho concreto em trabalho abstrato como um caso especial de uma reificação sistemicamente induzida de relações sociais, porque "parte do modelo do ator que age segundo uma racionalidade com respeito a fins, e que, ao ser despossuído de seus produtos, se vê também privado da possibilidade de desenvolver suas capacidades mais essenciais. A teoria do valor é desenvolvida segundo conceitos fundamentais da teoria da ação que tornam necessário situar a gênese da reificação por baixo do âmbito de interação e a tratar a deformação das próprias relações interativas (...) como fenômenos deduzidos" ${ }^{\text {233 }}$. Da mesma forma, a práxis revolucionária, cuja atividade só pode provir do trabalho, está circunscrita ao modelo do sujeito-objeto e conta tão somente com a racionalidade com respeito a fins do sujeito que age. Essa assimilação do trabalho social ao modelo da autoatividade teria, portanto, um "conteúdo normativo duvidoso" 234 , permancendo ambíguos tanto o conceito de trabalho quanto sua correspondente racionalidade com respeito a fins. "A filosofia da práxis", diz Habermas, "não oferece os meios para pensar o trabalho morto como intersubjetividade paralisada e mediatizada",235.

\footnotetext{
${ }^{232}$ Habermas, J. Theorie des kommunikativen Handels, Band. 2, op. cit., p. 494.

${ }^{233}$ Idem, p. 503-504. "Essa estrutura unilateral do conceito fundamental de ação, que permite entender a ação somente como uma atividade produtivo-objetiva, se vinga em uma subdeterminação do grau de indiferença que é dado com a redução do trabalho concreto em trabalho abstrato". Lohmann, G. "Gesellschaftskritik und normativer Maßtab”, op. cit., p. 271.

${ }^{234}$ Habermas, J. Der Philosophische Diskurs der Moderne, op. cit., p. 82.

${ }^{235}$ Ibidem.
} 
Vemos assim que, por meio do trabalho, os indivíduos aprendem a dominar o mundo natural e desenvolver o conhecimento instrumental e técnico. Contudo, seria a interação social que denotaria a especificidade da práxis humana e fundamentaria o núcleo normativo a partir do qual a dominação social poderia ser identificada e contestada. Nesse sentido, a expansão das forças produtivas não deixaria de explicar somente o que concerne ao complexo desenvolvimento das capacidades intersubjetivas, uma vez que a interação seguiria seu próprio padrão evolutivo, mas também, centralizada na produção, reduziria o potencial para emancipação presente na esfera da interação. Os processos de reificação descritos na crítica social de Marx mostrariam, antes, que a dimensão do trabalho produziria o oposto da atividade autônoma e da emancipação, ou seja, caracterizaria tais relações de interação social como independentes da vontade dos indivíduos, cuja lógica se reproduz de acordo com os próprios imperativos que se autonomizam ${ }^{236}$. Por isso, esse estreitamento do conceito de práxis significaria assim que a dimensão determinante e constitutiva da política no processo revolucionário seria enfraquecida, uma vez que tal processo não poderia ser avaliado a partir da autodeterminação dos agentes, mas esta autodeterminação teria de "ser esclarecida antes a partir das contradições da vida material, dos conflitos existentes entre as forças produtivas da sociedade e as relações de produção" ${ }^{\text {237 }}$. E no momento em que deduz a luta de classe da lógica de reprodução capitalista, a solução política passa a depender de um processo "que se realiza pelas costas das classes que estão em luta"238.

Ao crescimento das forças produtivas e à correspondente emancipação da sociedade diante das forças da natureza, por conseguinte, não corresponderia imediatamente uma diminuição da opressão social e política. Os dois desenvolvimentos não convergiriam necessariamente. Na verdade, eles seriam, em grande medida, independentes. "A libertação da fome e da miséria", diz Habermas, "não converge necessariamente com a libertação da servidão e da humilhação, pois não há uma relação de desenvolvimento automática entre trabalho e interação" 239 . A dialética das forças produtivas e das relações de produção não abarcaria as dimensões da emancipação da sociedade presentes em outros âmbitos da ação social. Comentando tal problema, Thomas McCarthy acredita que a insistência na "heterogeneidade" ou "irredutibilidade" entre trabalho e interação consiste em negar a fusão entre techne e praxis, entre progresso técnico e conduta racional da vida, "que sabemos que se encontra nas raízes da ideologia tecnocrata. Racionalização não significa emancipação. $O$

\footnotetext{
${ }^{236}$ Cf. Marx, K. Zur Kritik der Politischen Ökonomie, op. cit., p. 8.

${ }^{237}$ Idem, p. 9.

${ }^{238}$ Wellmer, A. Kritische Gesellschaftstheorie und Positivismus, op. cit., p. 101.

${ }^{239}$ Habermas, J. “Arbeit und Interaktion”, op. cit., p. 46.
} 
aumento das forças produtivas e da administração consciente não leva por si mesmo a uma transformação das instituições baseadas na força por uma organização de relações sociais ligadas à comunicação isenta de dominação. Os ideais de domínio técnico da história e a libertação das forças quase-naturais da dominação política e social, bem como os meios para sua realização, são fundamentalmente diferentes. Por essa razão, é de importância decisiva para uma teoria crítica da sociedade que as diferentes dimensões da práxis social sejam tornadas explícitas; apenas então poderemos compreender sua interdependência"240.

Em razão do abandono das diferentes dimensões da práxis social, pressupostos fundamentais da teoria dos sistemas teriam sido derivados dessa imagem funcionalmente produtivista que perpassaria a crítica de Marx. Isso porque ele não explica, diz Habermas, "a relação entre interação e trabalho, mas, antes, sob o nome pouco específico de práxis social, reduz um ao outro, a saber, a ação comunicativa à ação instrumental (...) a atividade produtiva que regula o intercâmbio material da espécie humana com seu ambiente natural se torna o paradigma para a generalização de todas as categorias; tudo se resolve no automovimento da produção. Por causa disso, a brilhante intuição de Marx sobre a relação dialética entre as forças produtivas e as relações de produção pode facilmente ser confundida com algum tipo de mecanicismo"241. Confusão que ocorreria, primeiramente, porque, como vimos, o mecanismo de mercado interpretado segundo um modelo realista de socialização anônima não-intecional seria constitutivo para a teoria da sociedade em seu conjunto. Além disso, os traços mecaniscistas da perspectiva objetivadora de sua intepretação atingiriam o auge de sua radicalização: os processos de interação social, que se desenrolam segundo valores, normas e processos de entendimento, seriam determinados a partir de fora e se imporiam como mecanismos de socialização que se reproduzem segundo seus próprios imperativos. Nesse caso, Marx teria atentado não apenas para somente um dos elementos constitutivos da reprodução material da sociedade, o sistema econômico, mas também reduziria tanto a organização estatal como a práxis de autodeterminação reflexiva aos efeitos colaterais de um processo unilateral e reificante - tal seria o resultado do modelo da base/superestrutura. Esse funcionalismo marxista seria caracterizado pela descrição da sociedade cristalizada sob as coerções de um processo de acumulação repetitivo, que se acelera e que tudo perpassa, transformando-se em um mundo de relações sociais reificadas. "Essa teoria do sistema",

\footnotetext{
${ }^{240}$ McCarthy, T. The critical theory from Jürgen Habermas. Massachssets Institute of Technology, 1985, p. 36.

${ }^{241}$ Habermas, J. “Arbeit und Interaktion”, op. cit., p. 45-46.
} 
comenta Habermas, "consegue configurar o seu sentido melancólico graças à relação com uma totalidade interpretada de modo negativo, como complexo de coerção"242.

Mas, além disso, o perigo dessa abordagem consistiria, sobretudo, na sua história dos efeitos, ou seja, na reatualização meramente funcionalista da crítica de Marx, pois a teoria dos sistemas, não mais configurada pelo seu sentido melancólico e negativo, delineada agora em termos positivos, "perde seu aguilhão crítico" ${ }^{243}$. Os sujeitos que constituem seus próprios mundos, ou que o compartilham de forma intersubjetiva, perderiam seu lugar nos processos de integração social, isto é, as interações realizadas de forma consciente dariam lugar à mera reprodução funcional. Todos os vestígios reflexivos, nos quais uma teoria da sociedade, que parte da autocompreensão dos atores, ainda poderia encontrar acesso à sociedade, seriam apagados. E com essa "radicalização da análise marxiana do sistema" os ganhos analíticos da teoria corresponderiam a perdas para uma teoria com intenções prático-emancipatórias.

A distinção entre a dimensão da ação ligada ao trabalho e aquela atrelada à ação simbólica e reflexiva seria necessária, assim, para uma compreensão da dinâmica política em que as condições da emancipação social se encontrassem em disputa. E com isso, Habermas não pretende excluir da dimensão política as questões ligadas à esfera do trabalho, muito menos as contradições sociais resultantes das relações econômicas. "Desde minhas primeiras publicações”, explica Habermas, “entendi 'materialismo' no sentido marxista como uma abordagem teórica que não simplesmente afirma a dependência da superestrutura em relação à base, do mundo da vida em relação aos imperativos do processo de acumulação, como uma constante ontológica, mas ao mesmo tempo a explica e denuncia como função latente de uma formação social particular e historicamente transitória. A transição de um paradigma ligado à produção para um paradigma ligado à comunicação, que advogo, significa naturalmente que a teoria crítica da sociedade não precisa mais se fiar nos conteúdos normativos do modelo expressivista de alienação e reapropriação de forças essenciais. (...) A mudança de paradigmas, de uma atividade voltada a um fim a uma ação comunicativa, não significa, porém, que eu abandono a reprodução material do mundo da vida como referência privilegiada de análise. Continuo a explicar o modelo seletivo da modernização capitalista e as correspondentes patologias de um mundo da vida unilateralmente racionalizado nos termos de um processo de acumulação capitalista amplamente desvinculado de qualquer orientação por valores de uso"244. Mas mesmo que as análises críticas de uma teoria da sociedade se orientem pela identificação dos efeitos reificantes dos sistemas sobre o mundo da vida, ainda

\footnotetext{
${ }^{242}$ Habermas, J. Faktizität und Geltung, op. cit., p. 66.

243 Ibidem.

${ }^{244}$ Habermas, J. "Ein Interview mit der New Left Review", op. cit., p. 244.
} 
assim o mundo da vida "não é uma superestrutura determinada pela base, pois também se determina a si mesmo, é autônomo"245.

O modelo de ação baseado no trabalho permitiu, assim, que Marx pudesse pressupor um tipo de conhecimento da totalidade - deduzido de uma concepção de sociedade moderna que se realiza fundamentalmente por meio do trabalho - que "se permite fazer laudos clínicos sobre a qualidade alienada e não-fracassada das formas de vida em seu conjunto"246. Habermas, por sua vez, não pretende colocar o mundo da vida em uma unidade superior, tal como aconteceria na relação entre trabalho e natureza. O âmbito da interação simbólica não pode ser representado segundo um modelo de autoprodução nem mesmo como a autorealização de um macrosujeito: ambos encerram um conceito de totalidade não mais adequado às diferenciações altamente complexas das sociedades modernas. Além disso, hipostasiaríamos também o processo de acordo e negociação intersubjetiva tal como acontece em uma concepção de práxis fundada no processo de trabalho, uma práxis pensada como uma totalidade de um sujeito de nível superior.

Vimos que a orientação revolucionária pôde antecipar as condições totais de uma sociedade emancipada e determinar a "qualidade alienada e não-fracassada das formas de vida em seu conjunto" apenas porque determinou de antemão a dimensão da luta social a partir das relações econômicas. Se, diferentemente, atribuíssemos uma dinâmica própria à esfera da interação política, então as contradições sociais estariam vinculadas à vida material de uma outra perspectiva que não necessariamente aquela apresentada pelo paradigma produtivista: as contradições sociais seriam diagnosticadas criticamente porque estariam fundadas na discrepância entre a realização possível e a opressão factual das necessidades reais dos indivíduos, ou seja, elas só seriam contradições porque, na interpretação e legitimação de suas necessidades, os grupos sociais se colocariam em contradição com as interpretações e legitimações tradicionais que formariam as relações de dominação existente. "Mas isso significaria", afirma decisivamente Wellmer, "que as formas com que os homens tomam consciência de seus conflitos sociais e os disputam não seriam apenas epifenômenos das contradições 'objetivas' entre forças produtivas e relações de produção, mas antes seus momentos constitutivos",247.

\footnotetext{
${ }^{245}$ Tomberg, F. Habermas und der Marxismus, op. cit., p. 300.

${ }^{246}$ Habermas, J. "Die nachholende Revolution und linker Revisionsbedarf: Was heißt Sozialismus heute?", op. cit., p. 191. "A 'visão de mundo' socialista é a única correta, porque ela 'reproduz' correta e dialeticamente a lei cósmica da natureza e da história”. Habermas, J. "Zwischen Philosophie und Wissenschaft: Marxismus als Kritik", op. cit., p. 266-267.

${ }^{247}$ Wellmer, A. Kritische Gesellschaftstheorie und Positivismus, op. cit., p. 102. (Os grifos são nossos).
} 
Como procuramos investigar, a teoria com intenções emancipatórias pode pretender identificar obstáculos à emancipação ou os potenciais emancipatórios presentes em determinado contexto ao manter em aberto o processo de autodeterminação. Se o sentido da emancipação tem de ser entendido como disputa, ou seja, como a luta pela autonomia na definição, interpretação e também constituição dos próprios processos sociais, não poderíamos decidir de antemão (por razões teóricas ou práticas) os rumos de um projeto político sempre inacabado ${ }^{248}$. "Na melhor das hipóteses", ressalta o próprio Habermas, "uma teoria [poderia] indicar as condições necessárias para formas de vida emancipadas, cuja configuração concreta teria de ser primeiramente decidida pelos próprios concernidos"249.

\footnotetext{
${ }^{248}$ Cf. Habermas, J. "Die Moderne - ein unvollendetes Projekt". In: Habermas, J. Kleine politische Schriften IIV. Frankfurt/M, Suhrkamp, 1981.

${ }^{249}$ Habermas, J. J. “Die nachholende Revolution und linker Revisionsbedarf: Was heißt Sozialismus heute?”, op. cit., p. 191.
} 


\section{Capítulo 2}

\section{Emancipação e reforma}

Com a Revolução Industrial, o liberalismo entrava em cena como ideologia política e econômica: a expansão do capitalismo lhe conferia autoridade para a explicação e justificação da "grande transformação" a que a sociedade fora submetida. A fé no progresso permitia aos liberais acreditar que o mercado poderia satisfazer as necessidades do maior número de pessoas, convencidos de que o governo deveria interferir o menos possível na marcha da história. Porém, as conseqüências negativas do capitalismo levavam seus críticos a formular alternativas que, como ficou marcado na história do socialismo, caracterizavam-se pela possibilidade de sua revolução ou de sua reforma. Vimos que, para o marxismo ortodoxo, o capitalismo continha em si os germes da futura sociedade socialista: o desenvolvimento econômico levaria às contradições internas do sistema e, por conseguinte, à sua revolução. Contudo, pressupostos fundamentais que compunham as orientações do paradigma revolucionário foram sendo colocados em questão, sobretudo porque algumas previsões de Marx não ocorreram. Nesse momento, surgiam críticas no quadro do movimento socialista internacional em relação a certa inadequação do marxismo como orientação da práxis política. Embora os muitos partidos que agiam em nome de Marx ainda exercessem um papel importante em diversos países da Europa no final do século XIX, o marxismo dava mostras de sua dificuldade em fornecer uma nova estratégia com a qual a esquerda pudesse utilizar sua força política e alcançar objetivos práticos. Em suma, na virada para o século XX, a esquerda se via diante do seguinte dilema: o capitalismo estava se desenvolvendo juntamente com as injustiças econômicas e a fragmentação social, mas os revolucionários contavam com as contradições que levariam ao colapso do sistema capitalista, o qual, contudo, parecia algo improvável. A outra resposta da esquerda para tais "frustrações"1 surgiu do interior do movimento social-democrata.

Durante os debates travados no âmbito dos congressos da Segunda Internacional, entre os anos de 1890 a 1914, e em oposição àqueles influenciados mais diretamente pelos acontecimentos na Rússia, que apostavam em uma superação político-revolucionária direta, surge uma corrente revisionista que daria início a uma cisão no interior da própria social-

\footnotetext{
${ }^{1}$ Berman, S. The primacy of politics: Social democracy and making of Europe's Twenthieth Century. Cambridge University Press, 2006, p. 14.
} 
democracia. Essa corrente, responsável pelo o que veio a ser considerado como a primeira crise do marxismo, iniciaria uma nova tendência de interpretação da teoria de Marx com base, sobretudo, na recusa de uma concepção dialética da história e na abdicação de pretensões revolucionárias. Muitos socialistas perceberam que, se os resultados políticos desejados não se efetivavam simplesmente porque a transformação do capitalismo seria considerada inevitável, a superação das condições de desigualdade e injustiça teria de ser implementada por outros meios. Em primeiro lugar, admitir-se-ia a via democrática rejeitada pela corrente revolucionária. Sabemos que a orientação emancipatória reformista se distinguirá da revolucionária, em última instância, não no que concerne aos objetivos políticos, mas aos meios e estratégias empregados para lidar com a relação entre capitalismo e a realização da verdadeira democracia ${ }^{2}$. Para que ocorresse uma total subversão do sistema econômico capitalista e, por conseguinte, do sistema político burguês, a emancipação por meio da revolução poderia envolver o recurso à violência, à luta armada e à insurreição como expressão da autodeterminação política. A superação dessa ordem burguesa foi pensada pelos reformistas, ao contrário, como uma transição democrática mais ou menos pacífica, realizada gradativamente por meio de reformas jurídicas, políticas e sociais. Mas certamente tudo dependia da posição de cada partido não apenas diante da questão da democracia, mas fundamentalmente diante do tema, central em ambos, da compreensão da natureza e das leis do capitalismo. O "revisionismo" ficou conhecido, portanto, por apresentar alternativas reformistas à teoria elaborada pelo socialismo científico: não apenas as estratégias revolucionárias, mas a teoria social na qual o marxismo se encontrava apoiado deveria ser revisada, pois a interpretação determinista, segundo a qual a sociedade capitalista se desenvolveria naturalmente para o socialismo, dava provas cada vez mais evidentes de sua insuficiência ${ }^{3}$.

Eduard Bernstein, um dos principais nomes da social-democracia alemã, atacou os dois pilares centrais do marxismo revolucionário - o socialismo científico e a luta de classes oferecendo alternativas baseadas no "primado da política" e na "cooperação entre as classes"4. Em linhas gerais, suas observações sobre o capitalismo implicavam notar que este não levava ao aumento da concentração de riqueza e à pauperização do proletariado, tornando-se antes

\footnotetext{
${ }^{2}$ Cf. Bobbio, N. "Reformismo, socialismo e igualdade". In: Novos Estudos, 19, 1987, p. 13 e ss.

${ }^{3}$ Certamente não se trata de uma posição homogênea. Cf. Tudor, H./Tudor, J. M. (ed.). Marxism and social democracy: The revisionist debate 1896-1898. Cambridge University Press, 1988; Kallscheuer, O. "Revisionismus und Reformismus". In: Fetscher, I./Münkler, H. (org.). Pipers Handbuch der politischen Ideen, Bd 4, München, 1985, 545 e ss.; e Andrade, J. "O Bernstein-Debatte e a indefinição da ala 'ortodoxa' da socialdemocracia alemã". In: Cadernos de ética e filosofia política. 11, 2007, p. 7-28.

${ }^{4}$ Berman, S. The primacy of politics: Social democracy and making of Europe's Twenthieth Century, op. cit., p. 49 e ss.
} 
mais complexo e adaptável. Na verdade, Bernstein nunca negou que o capitalismo pudesse entrar em colapso e chegar a uma crise final, porém essa lhe parecia uma possibilidade tão remota que procurou descartar formulações desse tipo da política concreta do partido socialdemocrata: em vez de esperar o colapso do capitalismo para a emergência do socialismo, ele defendeu uma reforma ativa e constante no sistema existente. Os objetivos do partido a serem perseguidos consistiam na expansão dos direitos civis com vistas ao avanço material e à ampliação da liberdade por parte da classe trabalhadora organizada. Desse modo, a relação entre capitalismo e democracia teria de ser reavaliada fora do contexto próprio da estratégia revolucionária, ou seja, com base em reformas sociais legais e pacíficas ${ }^{5}$. Para Marx, o capitalismo estaria apoiado em um conflito irreconciliável de interesses entre burguesia e proletariado, e como não haveria, em última instância, espaço para o compromisso entre tais interesses opostos, na maioria dos casos os revolucionários alegaram a dificuldade de poder haver uma transição pacífica do capitalismo ao socialismo. Ao passo que para Bernstein, no limite, as reformas vislumbradas poderiam modificar concretamente a forma de exploração capitalista, porém "tratar tais reformas como fins válidos em si mesmos (...) significava negar que uma tomada revolucionária do poder era necessária, e negar isso significa negar o caráter de classe da sociedade capitalista. Bernstein cruzou a fronteira que separava o marxismo revolucionário do socialismo democrático"6.

É a partir de Bernstein que vamos iniciar a caracterização da orientação reformista, embora ela seja mais importante para nosso argumento não de uma perspectiva histórica, mas da história dos efeitos de sua teoria sobre o reformismo social-democrata do pós-guerra, período em que pretendemos nos concentrar ${ }^{7}$. Pois muitos indícios levavam a crer que o programa reformista social-democrata seria uma opção mais plausível para uma orientação política progressista. Mas um outro dado importante seria decisivo para fundar esse tipo de afirmação, a saber, a transformação do capitalismo privado em um capitalismo de Estado: apesar de o capitalismo ter passado por um período de longa depressão, entrava em cena um Estado intervencionista capaz de estimular o crescimento econômico e, além disso, redistribuir a riqueza e assegurar o bem-estar da população ao se comprometer com reformas

\footnotetext{
${ }^{5}$ Cf. Bernstein, E. Die Voraussetzungen des Sozialismus und die Aufgaben der Sozialdemokratie. Berlin: Dietz, 1984, p. 214 e ss.

${ }^{6}$ Tudor, H./Tudor, J. M. (org). Marxism and social democracy: The revisionist debate 1896-1898, op. cit., p. 10.

${ }^{7}$ Estamos partindo de Scholing, M./Walter, F. (org.). Bernstein-Renaissance in der Sozialdemokratie. Göttingen, 1979, principalmente a introdução; e Meyer, T. Bernstein konstruktiver Sozialismus. Berlin: Dietz, 1977, p. 3940 e 102 e ss. Meyer é ainda mais explícito ao destacar a importância de Bernstein para a tradição social democrata. Em relação às políticas sociais do reformismo do pós-guerra, ver "Liberalismus und Sozialismus. Zwei Modelle ihrer Beziehung”. In: Meyer, T. Was bleibt vom Sozialismus? Hamburg: Rowohlt Verlag, 1991, p. 56-59; já em relação à bancarrota do sozialismo de Estado, o "modelo de Bernstein" é mais uma vez recuperado em "Sozialismus und Sozialdemokratie in Europa. Modelle für die Zukunft", idem, p. 112-115.
} 
sociais. Seria preciso admitir que, embora saído da tradição do socialismo democrático, esse projeto não foi de modo algum continuado somente por governos de perfil social-democrata. Após a Segunda Guerra Mundial, os partidos que conseguiram maioria (socialistas ou liberais) se estabeleceram em torno de programas sócio-estatais. Por essa razão, alguns autores procuraram sublinhar que os social-democratas mantiveram com mais força o discurso da necessidade das reformas sociais como estratégia política fundamental à realização do socialismo democrático provavelmente até o final da década de quarenta ${ }^{8}$, pois a perspectiva que iluminava as reformas sociais foi sendo enfraquecida e os partidos social-democratas passariam a assumir um discurso cujo tom seria apenas o do aperfeiçoamento da sociedade burguesa capitalista - ou, nos termos de Habermas, a "mera adaptação da herança liberalburguesa" - limitando as intenções e objetivos do que se entenderia por "novo reformismo social-democrata" ${ }^{\prime 10}$.

Em todo caso, a passagem do capitalismo privado para o capitalismo tardio forçava a reorientações teóricas e políticas, significando uma rejeição dos diagnósticos marxistas convencionais e, além disso, uma "formulação de diagnósticos alternativos"11. Por um lado, as tendências do capitalismo não se confirmaram, apesar dos acontecimentos da Revolução Russa de 1917 e, principalmente, da crise de 1929. Na verdade, contar com uma crise do capitalismo que ocasionasse sua autodestruição significava cada vez mais se apegar a um diagnóstico apartado da realidade, pois “a reestruturação do capitalismo após 1929 desmentiu a maioria das teorias da crise, que se estruturavam em torno da idéia de colapso. A profundidade da crise de 1929 foi inédita na história do capitalismo, mas, apesar disso, dela não resultou o colapso do modo de produção"12. O capitalismo tardio possibilitou a normalização do sistema e os conglomerados econômicos foram regulados e controlados com base em profundas intervenções estatais, dando provas de que a valorização do capital não somente seria possível como necessariamente passaria a depender da organização e da estabilização do mercado pelo Estado. Por outro lado, as intervenções deste no capital permitiam repensar novamente as relações entre capitalismo e democracia caso o Estado fosse capaz de cumprir seu programa de compensações sociais, permanecendo comprometido com

\footnotetext{
8 "Os social-democratas (...) perderam a fé na social democracia tradicional. Eles não estavam otimistas em relação ao seu próprio futuro. Eles tiveram dúvidas sobre si mesmos (...) Seu 'realismo' era sinal de que eles resolveram aceitar o inevitável, a saber, a superioridade do capitalismo". Sasson, D. One hundred years of socialism, op. cit., p. 733.

${ }^{9}$ Habermas, J. "Volkssouveränität als Verfahren”, op. cit., p. 618.

${ }^{10}$ Cf. Draper, H. “New social-democrat reformism”. In: New Politics, New York, v2, n. 2, 1963.

${ }^{11}$ Rugitsky, F. "Friedrich Pollock: Limites e possibilidades”. In: Nobre, M. (org.). Curso livre de teoria crítica. Campinas: Papirus, 2008, p. 61.

${ }^{12}$ Ibidem.
} 
as necessidades da sociedade. Embora historicamente a reorganização planificada da economia não tivesse levado a uma transição para o socialismo, a relação entre Estado e economia foi reestruturada de modo a permitir que a aposta em um novo compromisso social ainda pudesse ser considerada viável pela esquerda ${ }^{13}$.

Muitos autores reconheceram que a ortodoxia marxista dificilmente poderia apresentar uma explicação plausível sobre os fenômenos do capitalismo tardio, ou seja, o intervencionismo estatal, a democracia de massas e o Estado de bem-estar social ${ }^{14}$. Pois "a abordagem marxista", sublinha Habermas, "exige uma interpretação das sociedades capitalistas desenvolvidas que é reduzida a termos economicistas. Em relação a tais sociedades, Marx sustentou, com razão, um primado evolutivo da economia: são os problemas deste subsistema que determinam a linha evolutiva da sociedade em seu conjunto. Mas esse primado não nos deve levar a reduzir a relação complementar entre a economia e o aparelho estatal a uma representação trivial das relações entre base e superestrutura" ${ }^{\prime 15}$. Por essa razão, a via das reformas exigiu que a esquerda revisasse seus ideais para que não perdessem a força orientadora da ação. Essa revisão representou um avanço no seguinte sentido: marcava o abandono da perspectiva dogmática da luta de classes (pois passava a instituir compromissos políticos), da falsa atitude frente ao Estado democrático de direito (não mais considerando o direito como mera superestrutura, mas colocando-o permanentemente no interior da pauta de negociação política), da visão holista da sociedade (uma vez que a organização do trabalho não dependeria apenas do controle comunitário pensado como totalidade, mas estaria atrelada simultaneamente ao sistema político e econômico) e das hipóteses de fundo de uma ordem evolucionista (pois as reformas seriam transformações gradativas não movidas pela expectativa de um fim último). O marxismo mantinha-se preso a estes discursos e enfraquecia sua capacidade de compreensão da realidade ${ }^{16}$.

Porém, ainda que representasse um avanço em termos de compreensão da realidade, os reformistas permaneciam presos à utopia dominante de uma sociedade do trabalho. O que nos

\footnotetext{
${ }^{13}$ Para uma apresentação sistemática do surgimento e da ideologia do Estado de bem-estar social, ver Crosland, C. "Die Zukunft des Sozialismus". In: Narr, W- D./Offe, C. (org.). Wohlfahrtsstaat und Massenloyalität. Köln: Kiepenheuer \& Witsch, 1975, p. 72-98. Cf. ainda Arretche, M. "Emergência e desenvolvimento do Welfare State: teorias explicativas". In: BIB - Anpocs, 39, 1995.

${ }^{14}$ Em relação à posição de Habermas nesse debate, ver Giddens, A. "Razón sin revolución? La Theorie des kommunikativen Handels de Habermas". In: Bernstein, R. (ed). Habermas y la modernidad. Madrid, Cátedra, 1999, p. 175 e ss. Embora permanecendo no campo da economia política, uma longa análise das continuidades e reconfigurações impostas pelo capitalismo tardio à abordagem marxista pode ser encontrada em Mandel, E. Der Spätkapitalismus. Versuch einer marxistischen Erklärung. Frankfurt/M: Suhrkamp, 1973.

${ }^{15}$ Habermas, J. Theorie des kommunikativen Handels. Band. 2, op. cit., p. 504.

${ }^{16}$ Cf. Habermas, J. "Die nachholende Revolution und linker Revisionsbedarf: Was heißt Sozialismus heute?”, op. cit., p. 189-191. Cf. ainda Tomberg, F. Habermas und der Marxismus, op. cit. Partes I e II.
} 
importa ressaltar consiste em mostrar que, mesmo ao estreitar os laços com o desenvolvimento de um capitalismo pretensamente controlado pelo Estado, a realização de uma sociedade emancipada dos efeitos colaterais do trabalho heterônomo ainda nortearia o programa do Estado de bem-estar social. O reformismo não questionou o comprometimento utópico que herdou, orientando-se antes para o aperfeiçoamento das promessas não cumpridas da universalização da autorealização por meio do trabalho. Além disso, "um programa do Estado social, que se nutre reiteradamente da utopia de uma sociedade do trabalho, perdeu a capacidade de abrir possibilidades futuras de uma vida coletivamente melhor e menos ameaçada" ${ }^{17}$. Pois para poder conviver com o mercado capitalista, a social-democracia protegeria a utopia não somente ao procurar implementar politicamente a manutenção das condições de trabalho a uma população assegurada pelo ideal do pleno emprego, mas ao concretizar esse ideal com uma burocracia estatal cada vez mais paternalista. Ora, as expectativas mais realistas de emancipação, que apresentam a técnica, a ciência e o planejamento estatal como instrumentos promissores e seguros para um verdadeiro controle da sociedade, teriam sido abaladas por fortes evidências. Quanto mais complexos se tornavam os sistemas necessitados de controle, tanto maiores as probabilidades de efeitos colaterais disfuncionais: "nós percebemos diariamente que as forças produtivas se transformam em forças destrutivas, e que a capacidade de planejamento se transforma em potencial desagregador" $" 18$.

Gostaríamos de delinear os dois pilares da orientação refomista social-democrata a partir de uma distinção sugerida por Habermas. Primeiramente, pretendemos compreender o programa do Estado social a partir do projeto político mais amplo de universalização dos direitos civis, o qual necessariamente vincularia a busca por justiça social à realização da cidadania em uma sociedade do trabalho. Nesse caso, emancipação significaria humanização do trabalho, ou seja, transformação do trabalho considerado mercadoria em trabalho considerado a base de um direito de cidadania industrial. Mas além disso, a possibilidade de conciliar capitalismo e democracia dependeria das funções intervencionistas assumidas pelo Estado social para poder domesticar o capitalismo, assegurando seu desenvolvimento (I). Os limites da estratégia reformista foram avaliados em relação a uma contradição inerente a tal projeto de compensações sociais: ainda que o objetivo do Estado social tenha sido amenizar os efeitos colaterais e destrutivos do sistema capitalista e, ao mesmo tempo, criar condições sociais mais justas por meio de uma distribuição eqüitativa das oportunidades e dos recursos,

\footnotetext{
${ }^{17}$ Habermas, J. "Die Krise des Wohlfahrstaates und die Erschöpfung utopischer Energien”, op. cit., p. 147.

${ }^{18}$ Idem, p. 144.
} 
a sua implementação centralizadora gerou um aumento de controle, reificação e juridificação de determinadas esferas da vida. Não significa, certamente, que seria necessário recuar diante das conquistas obtidas com os programas de bem-estar social, pois não foi o Estado social enquanto tal que teria se revelado uma ilusão. Essa contradição entre fins emancipatórios e meios administrativos revelou antes que não seria mais possível "realizar formas emancipadas de vida por meios administrativos" ${ }^{\prime 19}$. Nesse sentido, o método do emprego do poder político se revelou inadequado para se alcançar o objetivo substancial de apoio e proteção de formas emancipadas de vida, ou seja, revelou a impossibilidade de produzir novas formas solidárias de vida com instrumentos burocráticos. A limitação do conceito do político à instância meramente administrativa do Estado domesticaria não o capitalismo, mas sim a democracia, engessando a possibilidade de uma práxis política autônoma (II).

\section{I - Capitalismo tardio e democracia: O programa do Estado de bem-estar social}

Afirmar que a utopia de uma sociedade do trabalho deixou marcas fundamentais no programa do Estado de bem-estar social, preconizado pela concepção reformista de emancipação, significa dizer que também nesse caso o núcleo utópico que caracterizaria as condições de vida emancipada e digna do homem corresponderia às condições bem sucedidas do trabalho. Não obstante, nesse caso, as condições da emancipação não resultariam diretamente de uma revolução das relações de trabalho, isto é, "de uma transformação do trabalho heterônomo em autoatividade" ${ }^{, 20}$. Aquelas seriam concebidas antes com base em um comprometimento social voltado à segurança econômica básica dos cidadãos e à proteção contra os riscos de uma economia de mercado, efetivando-se segundo uma série de políticas sociais $^{21}$. Portanto, a pretendida mudança das condições de trabalho seria alcançada por meio de reformas político-administrativas que visassem à normalização do status do trabalho assalariado dependente por meio da expansão dos direitos de participação política e de associação que propiciariam à massa da população a chance de viver em segurança, justiça social e bem-estar crescente ${ }^{22}$. Além disso, esse novo compromisso reformista surgiria assim

\footnotetext{
${ }^{19}$ Habermas, J. "Die nachholende Revolution und linker Revisionsbedarf: Was heißt Sozialismus heute?", op. cit., p. 192.

${ }^{20}$ Habermas, J. "Die Krise des Wohlfahrtsstaates und die Erschöpfung utopischer Energien”, op. cit., p. 147.

${ }^{21}$ Cf. Flora, P./Heidenheimer, A. J. (ed). The development of the Welfare State in Europe and America. New Brunswick: Transaction Books, 1987, p. xi-xv; e ainda Titmus, R. "Goals of Today's Welfare State". In: Anderson, P./Blackburn, R. (org). Towards socialism. London: Colins, 1965, p. 354-365.

${ }^{22}$ Cf. Habermas, J. "Volkssouveränität als Verfahren”, op. cit., p. 618.
} 
como uma alternativa política sedutora porque estava ancorada em uma realidade capitalista diferente daquela do século XIX e talvez tornasse viável a realização das promessas não cumpridas pelo liberalismo clássico, a saber, fazer convergir capitalismo e democracia, crescimento e eficiência com justiça social, "reino da necessidade" e "reino da liberdade".

Gostaríamos de descrever a convergência de ambos os desenvolvimentos lançando mão de uma distinção entre o lado substancial e o lado metodológico do projeto socialdemocrata sugerida pelo próprio Habermas. Segundo este, "o lado substancial do projeto nutre-se dos restos da utopia de uma sociedade do trabalho: como o status do trabalhador é normalizado pelo direito civil de participação política e pelo direito de associação, a massa da população tem a oportunidade de viver em liberdade, justiça social e crescente prosperidade" 23 . Nesse caso, a própria universalização dos direitos dos cidadãos seria interpretada como garantia de uma vida não fracassada na dimensão do trabalho. Porém, o êxito do projeto dependeria antes do poder e da capacidade de ação do aparelho intervencionista do Estado: este deveria intervir no sistema econômico com o objetivo de proteger o crescimento capitalista, minorar as crises e proteger simultaneamente a capacidade de competição das empresas e a oferta de trabalho. Este seria, portanto, o lado metodológico do programa social-democrata: "o compromisso do Estado social e a pacificação dos conflitos de classe devem ser obtidos através do poder estatal democraticamente legitimado, que é imposto para o zelo e a moderação do processo natural do desenvolvimento capitalista" ${ }^{24}$.

1. Justiça social e humanização do trabalho:

O lado substancial do programa social-democrata

A orientação emancipatória reformista marcou sua posição ao insistir na discrença em relação à interpretação marxista dominante que pensava a realização do socialismo com base nas leis objetivas do desenvolvimento capitalista e nas pretensões revolucionárias. Evidentemente, essa crítica tornaria necessária uma compreensão alternativa que ainda pudesse apontar em direção a certas mudanças da ordem capitalista. Em primeiro lugar, essas mudanças não poderiam mais ser motivadas pela visão utópica de uma sociedade perfeita, plena e harmônica. O socialismo seria qualitativamente melhor do que a sociedade capitalista, seria uma sociedade justa, com mais liberdade, verdadeiramente democrática, mas não

\footnotetext{
${ }^{23}$ Habermas, J. "Die Krise des Wohlfahrtsstaates und die Erschöpfung utopischer Energien”, op. cit., p. 148.

${ }^{24}$ Ibidem.
} 
poderia consistir em um fim último, um estado final para o qual passamos depois de atravessar o portal da revolução: teria de ser pensado antes não como fim, mas como uma tarefa constante, como "movimento" 25 . Além disso, ao se abdicar da práxis revolucionária e da capacidade de auto-organização espontânea do proletariado, os ideais socialistas teriam de ser realizados segundo uma estratégia de reformas democráticas por meio das quais se esperava capacitar o movimento operário para a transformação gradativa da sociedade capitalista. Isso implicava a adoção de estratégias políticas que permitissem, no interior do sistema democrático capitalista, a conquista gradual de melhorias para as classes trabalhadoras. Por essa razão, a relação dos reformistas com os princípios jurídico-políticos constitutivos das repúblicas democráticas seria bem diferente daquela dos marxistas revolucionários: o próprio socialismo, considerado a via emancipatória para o proletariado, seria impensável sem a preservação da estrutura da democracia. Desse modo, "reforma e revolução não requerem uma escolha, segundo a visão de mundo social-democrata. Para realizar a 'revolução social' (...) é suficiente seguir o caminho das reformas"26.

Ao defender essa necessidade de não tratar a democracia de uma forma meramente funcionalista para a realização do socialismo, a posição reformista reconheceu o parentesco entre seu programa e o liberalismo político ${ }^{27}$. Primeiramente, esse parentesco se deveria, entre outras coisas, ao objetivo comum de universalização dos direitos civis. Sabe-se que, embora se exigisse que a forma de socialização dos meios de produção estivesse nos objetivos dos programas reformistas, o socialismo que autores como Bernstein haviam vislumbrado pretendia dar mais atenção às liberdades civis do que a postulados econômicos. Teríamos de ampliar a idéia de socialismo para a idéia de democratização progressiva de todos os âmbitos da sociedade: a luta proletária visava à ampliação da liberdade para todos os círculos sociais, liquidando gradativamente a diferenciação entre maiorias e minorias. A social-democracia não buscava transformar a sociedade burguesa em uma sociedade proletária, mas sim universalizar os direitos civis para que a sociedade capitalista em seu todo pudesse se transformar em uma sociedade socialista ${ }^{28}$. Desse modo, em Bernstein se torna explícito que o

\footnotetext{
${ }^{25}$ Cf. Bernstein, E. Die Voraussetzungen des Sozialismus und die Aufgaben der Sozialdemokratie, op. cit., p. 200 e ss.

${ }^{26}$ Przeworski, A. Capitalismo e social-democracia. São Paulo: Companhia das Letras, 1989, p. 46-47.

${ }^{27}$ Cf. Bernstein, E. Die Voraussetzungen des Sozialismus und die Aufgaben der Sozialdemokratie, op. cit., p. 147-169. Ver também Kautsky, K. Die Diktatur des Proletariats. Vienna, 1918, capítulo II. Esse vínculo aparece claramente nas obras de Friedrich Naumann. Cf. Theiner, P. Sozialer Liberalismus und deutsche Weltpolitik. Friedrich Naumann im Wilhelminischen Deutschland (1860-1919). Nomos, 1983, capítulos 3 e 4 . Tal parentesco é igualmente assumido em Fetscher, I. Demokratie zwischen Sozialdemokratie und Sozialismus. Berlin: Kohlhammer, 1973, p. 142 e ss.

${ }^{28}$ Cf. Bernstein, E. Die Voraussetzungen des Sozialismus und die Aufgaben der Sozialdemokratie, op. cit, p. 158159.
} 
socialismo não se constituiria por uma contra-posição ao liberalismo, pois não apenas segundo suas "consequiências históricas, mas também segundo seu conteúdo espiritual”, o socialismo seria o "herdeiro legítimo" do liberalismo político ${ }^{29}$.

Contudo, a própria concepção de um socialismo democrático surgiu da crítica reformista ao direito formal burguês, e não simplesmente de sua mera adaptação. A concepção liberal estava apoiada em uma noção específica de direito, formulando-a como direito privado. Nesse caso, dava-se atenção à autodeterminação individual, entendendo-a como liberdade negativa de fazer ou não fazer o que se deseja, e a garantindo segundo proteções jurídicas que incluíam direitos da pessoa e de proteção contra delitos, liberdade de contratos (especialmente no caso da troca de bens e serviços) e direito à propriedade. Um processo complexo de "materialização do direito privado" - em cuja gênese estaria o surgimento de novos conflitos sociais e, por conseguinte, novos âmbitos de regulação jurídica - romperia as fronteiras dessa noção liberal ${ }^{30}$. Para uma orientação socialista que adotava a via democrática, esse processo forçava a uma ampliação do conceito do político em direção a questões sociais e exigia também uma mudança de compreenção da relação entre política e direito: "o direito privado em seu conjunto parecia se estender para além do objetivo da garantia da autodeterminação individual e deveria se colocar a serviço da realização da justiça social",31.

Acontecimentos decisivos separaram historicamente o reformismo de Bernstein daquele desenvolvido a partir da década de quarenta. Contudo, o vínculo com o liberalismo político e a universalização dos direitos civis nos programas jurídico-políticos nos permite reconhecer um fio condutor entre diferentes correntes históricas da social-democracia, que levaria das reformas legislativas do final do século XIX aos programas de bem-estar social do pós-guerra do século XX. Esse desenvolvimento de universalização dos direitos civis percorreria desde os direitos civis de autodeterminação individual, passando pelos direitos políticos de liberdade política, até a consolidação dos direitos sociais. Tal desenvolvimento foi abordado no texto clássico de Tomas Marshall ${ }^{32}$. Segundo a divisão sugerida por Marshall

\footnotetext{
${ }^{29}$ Ibidem. O autor chega a afirmar que "de fato, não há qualquer idéia liberal que também não pertença ao conteúdo de idéias do socialismo”. Idem, p. 160.

${ }^{30}$ Cf. Habermas, J. Faktizität und Geltung, op. cit., 472-492. Ver ainda Weber, M. "Sociología del derecho". In: Weber, M. Economia y sociedad. México: Fondo de Cultura Económica, 2004; Neumann, F. The rule of law. Political theory and the legal system in modern society., op. cit.; e Ewald, F. "A concept of social law". In: Teubner, G. (org.). Dilemmas of law in the welfare state. Berlin/New York, 1985, 40-75.

${ }^{31}$ Habermas, J. Faktizität und Geltung, op. cit., p. 479-480.

${ }^{32}$ Cf. Marshall, T. "Citzenship and social class". In: Marshall, T. Class, citzenship, and social development. Westport: Greenwood Press, 1973, p. 65-122. Nossa referência a Marshall está centrada em sua sistematização do desenvolvimento da cidadania (p. 65-83), e não no processo de implementação dos direitos sociais específico do Welfare State inglês.
} 
entre direitos civis, políticos e sociais, sob pontos de vista normativos, os primeiros protegeriam o sujeito de direito privado contra intromissões ilegais do Estado na vida, liberdade e propriedade; os direitos de participação, por sua vez, possibilitariam ao cidadão uma participação ativa no processo democrático da formação da opinião e da vontade; por fim, os direitos de participação social garantiriam ao cidadão pretensões compensatórias para uma distribuição justa da riqueza, assegurando, entre outras coisas, um salário mínimo e segurança $\operatorname{social}^{33}$. Os direitos liberais, que se cristalizaram historicamente em torno da posição social do proprietário privado, seriam formulados como a garantia de determinadas liberdades subjetivas privadas, e os direitos democráticos viriam complementar os direitos negativos à liberdade. Já os direitos sociais preencheriam os dois tipos anteriores, de modo que um número maior de pessoas pudesse adquirir plenos direitos como membros de uma comunidade jurídica aos quais seria assegurado o bem-estar econômico ${ }^{34}$.

A partir dos processos apresentados por Marshall seria possível entender mais especificamente que a universalização dos direitos civis corresponderia à gradativa inclusão dos cidadãos nos processos de modernização capitalista: sua reconstrução evolutiva da ampliação da cidadania mostraria que, por ser economicamente motivada, a luta de classes orientaria os direitos sociais para a maior inclusão possível de pessoas nos mercados, empresas, empregos, bem como cargos, associações políticas, sindicatos, etc., evidenciando assim que o desenvolvimento da cidadania e dos direitos sociais coincidiria com o crescimento do capitalismo e sua respectiva produção de desigualdade social ${ }^{35}$. Também para outros autores, essa distinção diante dos liberais, marcada pela preocupação com a ampliação das liberdades civis para as questões de justiça social, implicava continuar atrelando as tarefas do novo reformismo social-democrata aos efeitos colaterais do mercado capitalista e, por conseguinte, à reforma do mundo do trabalho ${ }^{36}$. Foi exatamente isso que o socialismo democrático procuraria realizar ao tentar assegurar a humanização do trabalho com base nos direitos sociais: apesar das diferenças históricas, não desatrelaram os critérios de justiça social

\footnotetext{
${ }^{33}$ Cf. idem, p. 71-83.

${ }^{34}$ Idem, p. 72. Cf. Habermas, J. Faktizität und Geltung, op. cit., p. 104-105.

${ }^{35}$ Cf. Marshall, T. "Citzenship and social class", op. cit., p. 84 e ss.

${ }^{36}$ Essa referência é retomada em outra situação histórica em Castel, R. Les métamorphoses de la question sociale, op. cit., p. 731 e ss; e Gorz, A. "Revenu minimum et citoyenneté, droit au travail et droit au revenu". In: Futuribles, fevereiro, 1993, p. 22 e ss; também Gorz, A. Metamorfoses do trabalho: Crítica da razão econômica, op. cit., 202-203.
} 
da possibilidade de uma "desmercantilização" da força de trabalho que só poderia ser implementada pela interferência jurídico-política na economia ${ }^{37}$.

Mas outras importantes semelhanças e particularidades entre liberalismo e socialdemocracia saltam aos olhos se acrescentarmos a esse desenvolvimento o fato de que, opondo-se à teoria do colapso, o reformismo desde sempre se apoiou em uma "teoria da adaptação ao capitalismo" ${ }^{\text {"3 }}$. Não se tratava, em princípio, de uma mera adaptação, mas sim de um controle politicamente planejado do capitalismo. Pensava-se que as lutas sociais, organizadas nos sindicatos e aspiradas nas reformas políticas, levariam a um controle progressivamente mais abrangente sobre as condições de produção e a uma diminuição dos direitos do proprietário capitalista a ponto de a legislação limitar o papel deste a um simples administrador. No limite, tais reformas fariam assim com que o capitalista perdesse o controle sobre a direção e a administração da exploração até, finalmente, instituir-se um controle coletivo dos meios de produção. As demandas políticas por salário e a redução das horas de trabalho poderiam, na verdade, domesticar administrativamente o capitalismo ${ }^{39}$. Nesse caso, a reforma consistiria no mecanismo utilizado para que os indivíduos pudessem ver assegurados seus direitos a bens e serviços, pois "embora como produtores imediatos os trabalhadores não tenham direito legal ao produto, como cidadãos podem obter tal direito via sistema político. Ademais, novamente como cidadãos e não como produtores imediatos, podem intervir na própria organização da produção e na alocação dos lucros"

Mas decorre disso também uma outra diferença importante entre a compreensão liberal e a social-democrata, a qual residiria no fato de a primeira supor que o mercado e a sociedade econômica constituem uma esfera isenta de poder, ou seja, uma esfera na qual a intervenção estatal e as decisões políticas do governo não poderiam interferir. Segundo o modelo liberal, "uma sociedade econômica, institucionalizada por meio do direito privado (principalmente através de direitos de propriedade e da liberdade de contrato), deveria ser separada do Estado enquanto esfera de realização do bem comum e permanecer entregue à ação espontânea de mecanismos do mercado. Essa 'sociedade de direito privado' era caracterizada segundo a autonomia dos sujeitos de direito, os quais, enquanto participantes do mercado, buscariam e encontrariam sua felicidade por meio da persecução mais racional possível de seus próprios

\footnotetext{
${ }^{37}$ Cf. Esping-Andersen, G. "Citzenship and socialism: De-commodification and solidarity in the Welfare State". In: Martin, R./Esping-Andersen, G./Reinwater, L (org.). Stagnation and renewal. New York: Armonk, 1987, p. 82 e ss.

${ }^{38}$ Tudor, H./Tudor, J. M. (ed.). Marxism and social democracy: The revisionist debate 1896-1898, op. cit., p. 11.

${ }^{39}$ Berman, S. The primacy of politics: Social democracy and making of Europe's Twenthieth Century, op. cit., p. 51 e ss.

${ }^{40}$ Przeworski, A. Capitalismo e social-democracia, op. cit., p. 24.
} 
interesses. A expectativa normativa, segundo a qual a delimitação de esferas de liberdade individual, ou seja, a garantia de um status jurídico negativo (com a pretensão a uma correspondente proteção jurídica individual), garante a instauração da justiça social, apoiavase no entrelaçamento entre o princípio da liberdade jurídica e o direito universal à igualdade" ${ }^{41}$. Esse princípio da liberdade jurídica encontrava-se apoiado em certas hipóteses, já apresentadas anteriormente da perspectiva da economia política clássica, segundo as quais a sociedade civil poderia ser interpretada apenas com referência a um suposto equilíbrio dos processos organizados conforme a economia de mercado.

Contrariamente, o reformismo social-democrata só poderia apregoar a domesticação do capitalismo em detrimento de sua superação porque o poder político dos trabalhadores se efetivaria no Estado ${ }^{42}$. Primeiramente porque a implementação de uma reforma progressiva das condições do trabalho e das relações de produção seria inviável sem o aparelho estatal, pois não poderia se realizar sem as reformas legislativas impulsionadas pelos sindicatos. É bem verdade que já se procurava evitar teoricamente os riscos de um socialismo de Estado centralizado $^{43}$. Pressupunha-se, primeiramente, que as reformas jurídico-políticas produziriam medidas capazes de democratizar o Estado, ou seja, levá-lo a perder seu caráter de classe e assumir a defesa do interesse geral. Preocupações sobre a capacidade de organização política e administrativa já incluíam a expansão dos direitos civis e modelos alternativos de cooperativas em face do centralismo estatal. Porque a garantia de liberdade para todos só seria possível segundo organização, poderíamos, neste caso, inclusive "chamar o socialismo também de liberalismo organizado"44 do mesmo modo como o havia pensado Bernstein ${ }^{45}$. Contudo, o papel do Estado seria fundamental na implementação administrativa das reformas por possibilitar também uma realização planejada da liberdade em contextos sociais não entrevistos pelos liberais. Se na "sociedade do direito privado" as condições de uma vida não fracassada pretendiam ser produzidas a partir do equilíbrio dos processos econômicos regidos pelo mercado, de modo que a boa vida derivasse diretamente do interesse individual, essas condições passariam a depender fundamentalmente da introdução de direitos sociais capazes de preencher as pretensões de uma distribuição mais justa da riqueza socialmente produzida e

\footnotetext{
${ }^{41}$ Habermas, J. Faktizität und Geltung, op. cit., 484.

${ }^{42}$ Diferentemente de como pareciam querer os comunistas, o emprego do Estado não teria nem uma função apenas transitória e nem tão radical, levando-se em consideração seu papel no que os reformistas entendiam ser o processo de uma "improvável" apropriação coletiva direta dos meios de produção. Essa posição fica clara nas críticas que Bernstein dirigiu aos anarquistas. Cf. Tudor, H./Tudor, J. M. (ed.). Marxism and social democracy: The revisionist debate 1896-1898, op. cit., p. 55-56.

${ }^{43}$ Cf. Huhn, W. Der Etatismus der Sozialdemokratie, op. cit. P. 104 e ss.

${ }^{44}$ Bernstein, E. Die Voraussetzungen des Sozialismus und die Aufgaben der Sozialdemokratie, op. cit, p. 161.

${ }^{45}$ Cf. Meyer, T. "Liberalismus und Sozialismus. Zwei Modelle ihrer Beziehung”, op. cit., p. 56 e ss.
} 
proteger os membros da sociedade dos riscos do imperativo de autovalorização do capital. Nas condições da moderna sociedade industrial, a realização da liberdade e da igualdade, não podendo ser deduzida da sua própria forma de organização capitalista, dependeria fortemente das atividades do Estado para poder assegurar a justiça.

Para os social-democratas, portanto, os sindicatos, as reformas sociais com base na universalização dos direitos e uma necessária democratização política do Estado consistiriam nos meios primordiais para uma realização progressiva do socialismo. Apesar de o reformismo muitas vezes simplesmente se "inclinar em favor da saúde do capitalismo" ${ }^{46}$, de um ponto de vista normativo seu programa de realização progressiva de justiça social forneceria a base para a orientação política social-democrata que continuaria se estabelecendo a partir da década de quarenta: na época de Bernstein, tal realização progressiva foi possível por meio de reformas jurídico-políticas na legislação; após a Segunda Guerra Mundial, foi incorporada no programa de bem-estar social ${ }^{47}$. Embora a existência mesma do Estado social não possa ser funcionalmente desvinculada da exigência da industrialização e da acumulação do capital, como veremos, a partir das diferentes formulações seria possível compreender que seu modelo se caracterizaria também como produto da mobilização sindical e da luta política de classes e resultado da ampliação dos direitos de cidadania e da democracia. É nesse mesmo sentido que o modelo do Estado social foi interpretado também como herança bernsteiniana do socialismo democrático para a nova social-democracia ${ }^{48}$. Esse fio condutor para a reconstrução das bases normativas do programa social-democrata pode deixar escapar certas complexidades das diversidades de modelos, continuidades e descontinuidades de modos de realização das políticas reformistas. Os diversos modelos históricos e nacionais foram implementados segundo alguns padrões básicos, mas também diferenciados pela forma de organização institucional, forma de financiamento, pela extensão de seus serviços, o peso do setor público, etc $^{49}$. Contudo, as regulações e intervenções promovidas pelos sindicatos e partidos reformistas com a finalidade de melhorar a situação social dos trabalhadores - que começaria com a luta pelo direito de associação, depois a legislação sobre salários, condições de trabalho e melhorias sociais, estendendo-se por fim a diversos âmbitos de regulação dos programas de bem-estar, incluindo a política educacional, meios de transporte e política

\footnotetext{
${ }^{46}$ Draper, H. "New social-democrat reformism", op. cit., p. 36.

${ }^{47}$ Como parece ficar claro segudo a própria evolução histórica proposta por Marshall em "Citzenship and social class", op. cit., p. 95 e ss; ver também Crosland, C. "Die Zukunft des Sozialismus", op. cit., p. 87 e ss.; e Titmus, R. "Goals of Today's Welfare State", op. cit., p. 360 e ss.

${ }^{48}$ Cf. Scholing, M./Walter, F. (org.). Bernstein-Renaissance in der Sozialdemokratie, op. cit., introdução. Cf. também Meyer, T. Bernstein konstruktiver Sozialismus, op. cit., p. 102 e ss.

${ }^{49}$ Cf. Fiori, J. L. "Estado de bem-estar social: Padrões e crises". In: Instituto de Estudos Avançados, 2005; Esping-Andersen, G. “As três economias políticas do welfare state”. In: Lua Nova, 24, 1991.
} 
sanitária, etc. ${ }^{50}$ - denotariam normativamente o conteúdo político de um longo percurso na tentativa de universalização dos direitos civis, do bem-estar e da justiça.

Essas observações gerais já nos permitem caracterizar teoricamente o programa reformista, em primeiro lugar, por meio de sua aspiração à justiça social fundada na humanização do trabalho e, em segundo lugar, de acordo com sua tentativa de domesticação do capitalismo por via político-jurídica: em ambos os casos, o fio condutor de seu programa estaria orientado pela relação entre sociedade do trabalho e a ampliação do status de cidadão com pretensões de direito ${ }^{51}$. O modelo do Estado social surgiria para preencher as expectativas de justiça que não poderiam ser sanadas simplesmente com uma concepção de liberdade limitada ao "poder ter e poder adquirir" que caracterizava o liberalismo econômico. Pois "as condições de um capitalismo organizado, dependente de planejamento e de realizações de infra-estrutura por parte do Estado, bem como o aumento da desigualdade de posições de poder econômico, dos valores de capital e de situações sociais, manifestaram mais claramente o conteúdo objetivo dos direitos subjetivos privados. Em um contexto social tão modificado, o status negativo de sujeitos do direito não podia ser mais garantido apenas por meio do direito universal a liberdades subjetivas iguais" ${ }^{, 52}$. O núcleo substancial desse programa social-democrata consistiria, principalmente, em reformar as condições de emprego de modo que a atividade gerada pelo trabalho pudesse continuar não apenas satisfazendo as necessidades materiais da sociedade, mas assegurasse a cada um seu lugar legítimo na divisão social do trabalho. De uma perspectiva normativa, as condições de emprego permaneceriam assim como ponto de referência para a própria medida de justiça, sem as quais se violariam a dignidade da pessoa e seu reconhecimento como um cidadão com pretensões de direito ${ }^{53}$. Apoiando-se em Marshall, Axel Honneth entende que esse reconhecimento se estabelece "em torno da ampliação tanto do conteúdo material como do alcance social do status de uma pessoa de direito" ${ }^{\text {54 }}$. O que seria emancipatório no programa do Estado social consistiria, portanto, na possibilidade de transformar o trabalho considerado mercadoria em trabalho como base de um direito de cidadania industrial. Isso permitiria delinear mais uma vez um fio condutor entre as formulações teóricas do socialismo democrático e a pluralidade de experiências históricas e nacionais do Estado social, o qual consistiria na unificação de um programa de universalização dos direitos civis com um plano de regulamentação da economia

\footnotetext{
${ }^{50}$ Cf. Esping-Andersen, G. "Citzenship and socialism: De-commodification and solidarity in the Welfare State", op. cit, p. 83 e ss.

${ }^{51}$ Cf. Habermas, J. "Die Krise des Wohlfahrtsstaates und die Erschöpfung utopischer Energien”, op. cit., p. 147.

${ }^{52}$ Habermas, J. Faktizität und Geltung, op. cit., p. 485.

${ }^{53}$ Cf. Castel, R. Les métamorphoses de la question sociale, op. cit., p 619 e ss, e 731 e ss.

${ }^{54}$ Honneth, A. Luta por reconhecimento, op. cit., p. 194.
} 
de mercado de inspiração keynesiana. Não seria possível dissociar os objetivos de uma humanização do trabalho, por meio de direitos sociais e distribuição da renda, do objetivo do pleno emprego 55 .

Que o status de cidadão esteja intimamente vinculado ao trabalho, não implica que o conceito de trabalho seja caracterizado exatamente do mesmo modo como por vezes Marx o pensou, entendendo-o ora como trabalho heterônomo (alienado, abstrato, etc.), ora como trabalho autônomo (não-alienado, concreto, etc. ${ }^{56}$. Remediar os efeitos colaterais do mercado sobre a vida das pessoas não significaria assegurar uma posição direta no processo de autoatividade reunificado no trabalho. A atividade produtiva do trabalho por si mesma não seria emancipatória, mas sim as garantias políticas que mediariam as condições constitutivas de um trabalho dependente, ou seja, o comprometimento com o conjunto do sistema de empregos e a respectiva compensação dos riscos ligados à exclusão do mundo do trabalho: esse status jurídico possibilitou, segundo a reconstrução de Marshall, que o cidadão fosse incluído como membro com igual valor de uma comunidade política. Não se trata agora de "revolucionar as relações de trabalho", mas sim reformar as condições de emprego que são "ponto de referência não apenas para a medida de humanização de um trabalho que continua determinado de fora, mas sobretudo para as indenizações compensatórias que devem contrabalançar os riscos básicos do trabalho assalariado (acidentes, doença, perda do emprego, velhice desamparada) ${ }^{, 57}$. O trabalho não poderia mais ser caracterizado como uma autoatividade corporificada em "uma sociedade que organiza a si mesma como exercício do controle consciente ou da administração planejada do processo de produção material" ${ }^{, 58}$, pois agora dependeria da composição da divisão do trabalho em seu conjunto, a qual o Estado pretenderia administrar ${ }^{59}$.

A estratégia político-administrativa propriamente dita dependeria da capacidade do Estado em assegurar formas de vida igualmente estruturadas e compensar as condições sociais desiguais da sociedade capitalista por meio da distribuição mais justa de bens coletivos. Na verdade, poderíamos definir a própria política de bem-estar social como "persecução de fins coletivos no espaço de uma organização estatal" ${ }^{\text {. A }}$. A utilização do direito pelo Estado visaria à implementação desses fins, os quais estariam ligados à seleção de certos bens considerados

\footnotetext{
${ }^{55}$ Cf. Mishra, R. The welfare state in capitalist society. University of Toronto Press, 1990, p. 92 e ss, e 101.

${ }^{56}$ Cf. Lange, E. Das Prinzip Arbeit, op. cit., sobretudo parte 2.

${ }^{57}$ Habermas, J. "Die Krise des Wohlfahrtsstaates und die Erschöpfung utopischer Energien”, op. cit., p. 147.

${ }^{58}$ Habermas, J. Faktizität und Geltung, op. cit., p. 393.

${ }^{59}$ Cf. Kern, H./Schumman, M. Das Ende der Arbeitsteilung?. München, 1984, p. 89 e ss.

${ }^{60}$ Peters, B. Rationalität, Recht und Gesellschaft. Frankfurt/M: Suhrkamp, 1991, p. 81.
} 
coletivamente válidos. Por um lado, os bens coletivos seriam concebidos como valores a serem realizados pelo Estado, orientando assim seus objetivos práticos. Na definição de Bernhard Peters, "a disposição de bens coletivos é uma forma determinada de fim coletivo, a qual se caracteriza por seu significado prático. Bens coletivos são aqueles bens ou serviços produzidos ou distribuídos por meio de uma atividade comum, centralmente coordenada, de seus membros. Em regra, essa atividade não é realizada por seus próprios membros, mas sim por órgãos ou instituições comuns da comunidade" ${ }^{\natural 1}$. Por outro lado, essa política de bemestar teria de ser compreendida necessariamente com base na satisfação das necessidades consideradas legítimas, ou seja, como distribuição de valores de uso. Os bens coletivamente válidos seriam integrados a um "sistema de valores universalista"62 implementado por uma via substancialmente diferente daquela imposta pelo liberalismo econômico. Vimos que o liberalismo estava estreitamente apoiado no sistema de troca de equivalentes. A impossibilidade de garantir pelo processo de troca a universalização correspondente dos valores de uso, ou seja, da satisfação das necessidades ${ }^{63}$, caracterizaria esse sistema de valores universalista pelo fato de não mais pretender satisfazer as necessidades apoiado meramente nos interesses de valorização do capital: não seria mais a economia de mercado baseada no valor de troca, mas sim a distribuição politicamente organizada dos bens coletivos, ou seja, dos valores de uso, que poderia assegurar a satisfação das necessidades e criar, dessa forma, um sistema de valores pretensamente universal.

No caso do Estado de bem-estar social, a idéia de bens coletivos é especialmente ampla. O Estado procuraria justificar suas atividades ao pretender incorporar ao sistema de empregos todos aqueles aptos ao trabalho. Para que suas compensações fossem eficazes, o papel de assalariado por tempo integral passaria a se converter em norma. E como se trata de assegurar todas as condições constitutivas de um trabalho dependente, a meta coletiva do pleno emprego precisaria ser implementada segundo medidas indiretas. Cada medida seria justificada por produzir um bem coletivo em escala suficiente para assegurar bem-estar e justiça a toda a população. E tais bens não se limitariam à produção de mercadorias, mas envolveriam um planejamento global ligado a "insentivos e investimentos, indenizações, postos de trabalho, etc" ${ }^{\text {64 }}$. Tal planejamento abarcaria fenômenos como créditos governamentais, subvenções, empréstimos (ligados ao crescimento sustentável, estabilidade

\footnotetext{
${ }^{61}$ Idem, p. 83-84.

${ }^{62}$ Cf. Habermas, J. Legitimationsprobleme im Spätkapitalismus, op. cit., p. 84.

${ }^{63} \mathrm{O}$ valor de uso seria caracterizado segundo sua possibilidade de satisfação das necessidades humanas. Cf. Heller, A. Theorie der Bedürfnisse bei Marx, op. cit., p. 23 e ss.

${ }^{64}$ Peters, B. Rationalität, Recht und Gesellschaft, op. cit., p. 88.
} 
da moeda e pleno emprego), produtividade no trabalho (educação, programas de capacitação), compensações sociais (seguro desemprego, bem-estar), lazer, etc. Além disso, as regulações e prestações do Estado social não teriam apenas como objetivo a realização de um equilíbrio social adquirido a partir de compensações individuais, mas também a correção de efeitos coletivamente perceptíveis, como na planificação de cidades e do tráfego, da política energética, política sanitária, equilíbrio ecológico, cultura, etc ${ }^{65}$.

Se entendermos a justiça social como o resultado de uma humanização do trabalho alcançado por meio de indenizações compensatórias, é possível delinear os mecanismos empregados pelo Estado para o apaziguamento dos conflitos de classe e, por conseguinte, a formação de um possível compromisso político. Esses mecanismos se caracterizariam evidentemente por essa política de compensações e indenizações. O apaziguamento dos conflitos de classe seria alcançado, primeiramente, por meios legislativos, sobretudo no que diz respeito às negociações coletivas por barganha salarial e redução da jornada de trabalho ${ }^{66}$. Pois o núcleo do compromisso do Estado social se fundava na legislação trabalhista e nos direitos sociais com os quais poderiam ser adotadas medidas capazes de cobrir os riscos básicos da existência dos trabalhadores dependentes e também para compensar as desvantagens que resultariam de posições menos favorecidas no mercado. A política social absorveria os prejuízos e inseguranças do processo de acumulação, mas deixaria intactas as relações de propriedade, de renda e de dependência do trabalho. Apesar disso, a institucionalização jurídica em torno da fixação dos salários e das condições de emprego se converteria, assim, na base de uma política reformista, já que "a alavanca para o apaziguamento dos antagonismos de classe permanece, pois, a neutralização dos materiais de conflito inerentes ao status de trabalhador assalariado"67. Contudo, essa compatibilidade entre democracia e capitalismo, como mostrou Claus Offe, passou a depender "de uma garantia virtual de que a estrutura do poder político não se desviará excessivamente da estrutura de poder sócio-econômico" $"$.

Por essa razão, o apaziguamento dos conflitos de classe dependeria da relação entre o papel de trabalhador, de cidadão e de consumidor. Mas nesse caso, os direitos sociais não

\footnotetext{
${ }^{65}$ Cf. Narr, W- D./Offe, C. (org.). Wohlfahrtsstaat und Massenloyalität, op. cit., p. 22-25.

${ }^{66}$ Cf. Achten, U. Recht auf Arbeit, eine politische Herausforderung. Neuwied/Darmstadt, 1978, p. 27-28; e também Hinrichs, K./Offe, K./Wiesenthal, H. "Der Streit um die Zeit - Die Arbeitszeit im gesellschaftspolitischen und industriellen Konflikt". In: Offe, C. "Arbeitsgesellschaft". Strukturprobleme und Zukunfsperspektive, op. cit., p. 143.

${ }^{67}$ Habermas, J. "Die Krise des Wohlfahrtsstaates und die Erschöpfung utopischer Energien”, op. cit., p. $147-148$.

${ }^{68}$ Offe, C. "A democracia partidária competitiva e o Welfare State keynesiano: fatores de estabilidade e organização”. In: Offe, C. Problemas estruturais do Estado capitalista. Rio de Janeiro: Tempo Brasileiro, 1984, p. 365.
} 
poderiam ser considerados apenas sob uma perspectiva normativa, ou seja, como direitos que asseguram pretensões por uma distribuição justa da riqueza e pela universalização de um sistema de valores, mas também sob pontos de vista funcionais. Funcionalmente, os direitos liberais poderiam ser entendidos como a institucionalização de um sistema econômico dirigido pelo mercado. Já os direitos sociais significariam a instalação de burocracias administradas pelo Estado social ${ }^{69}$. A domesticação do capitalismo, a humanização do trabalho e o aumento médio da renda proporcionariam ao sistema administrativo remodelar artificialmente as condições não fracassadas da vida. $\mathrm{O}$ papel de trabalhador perderia gradativamente sua imagem mais cruel não apenas porque os direitos sociais proporcionariam um aumento contínuo do nível de vida, ainda que diferenciado segundo os distintos estratos sociais. O status de trabalhador seria ainda incorporado ao de cidadão e normalizado ficticiamente, isto é, tratado de forma meramente administrativa ao ser assimilado pelas burocracias dos programas sociais $^{70}$. Primeiramente, haveria um equilíbrio que se estabeleceria entre o papel universalizado de cidadão e um correspondente papel de cliente da burocracia do Estado de bem-estar ${ }^{71}$. Nesse caso, a pretensão por direitos sociais seria preenchida uma vez que os especialistas das burocracias pudessem submeter os indivíduos a um processo de abstração: o reconhecimento do cidadão com pretensões de direito seria assimilado à lógica do aproveitamento individual, em que se atribui ao cliente da burocracia a possibilidade de usufruir os programas sociais. O cidadão "adquire, por assim dizer, as qualidades de ator das agências do Estado"72. Por outro lado, surgiria também um novo equilíbrio entre o papel normalizado de trabalhador e o papel valorizado de consumidor, pois o cidadão necessariamente precisaria poder continuar exercendo seu papel de consumidor de bens de massa $^{73}$. Desse modo, essa complementação administrativa possibilitaria que o cidadão fosse indenizado assim não apenas em seu papel de cliente que vê assegurado seus direitos sociais, mas também no seu papel de consumidor, ao ver assegurado seu poder de compra.

Veremos, contudo, que a necessidade de regulação de todo um sistema de trabalho dependente, o qual, além do direito ao trabalho, abrangeria toda a base material para uma existência digna (segurança, saúde, educação, habitação, lazer, etc.), delineia os traços inevitáveis dos "projetos paternalistas de uma vontade política superior, que domina essas

\footnotetext{
${ }^{69}$ Cf. Habermas, J. Faktizität und Geltung, op. cit., p. 105.

${ }^{70}$ Cf. Offe, C. "Klassenherschaft und politisches System. Zur Selektivität politischer Institutionen“. In: Offe, C. Strukturprobleme des kapitalistischen Staates, op. cit., p. 74 e ss.

${ }^{71}$ Cf. Habermas, J. Faktizität und Geltung, op. cit., p. 105.

${ }^{72}$ Idem, p. 490.

${ }^{73}$ Cf. Habermas, J. "Die Krise des Wohlfahrtsstaates und die Erschöpfung utopischer Energien”, op. cit., p. 147.
} 
contingências sociais por meio da regulação e da organização social" ${ }^{14}$. O indivíduo teria à sua disposição um número cada vez maior de "sociedades" dentro da própria sociedade, nas quais seria incluído pelos programas sociais. Mas isso poderia resultar em uma "descrição neutra com relação a ganhos e perdas de autonomia”, pois tais programas seriam cegos ao aproveitamento real de um "status de cidadão ativo do Estado, através do qual o indivíduo pode influir na transformação democrática de seu status ${ }^{\text {"75 }}$. No programa reformista, a inclusão social e a universalização dos direitos dependem fundamentalmente dos benefícios (sejam materiais ou imateriais) diante da distribuição dos bens coletivos e do proveito individual avaliado em termos de valores de uso. Mas essa política de compensações e indenizações regulada de modo distributivo - na qual, com a distribuição dos valores de uso, se esperaria produzir o consentimento dos cidadãos ao transformá-los em clientes que se beneficiam dos programas e consumidores que restituem seu poder de compra - apaziguaria os conflitos de classe congelando, por sua vez, a práxis de autodeterminação que acompanharia necessariamente o projeto de universalização dos direitos civis, o qual não se limitaria aos direitos sociais, mas estaria vinculado também à ampliação da liberdade política: o preço a ser pago pelos benefícios da distribuição consistiria no abandono da autonomia ${ }^{76}$.

\section{Domesticação do capitalismo:}

O lado metodológico do programa social-democrata

O núcleo substancial do programa reformista estava apoiado nesse conjunto de direitos que normalizavam o status do trabalho dependente, assegurando por conseguinte a justiça social e o bem-estar da população. Porém, a coexistência entre capitalismo e democracia implicava, além disso, implantar tais direitos e cumprir os objetivos estabelecidos pelo compromisso social "na base de um capitalismo disciplinado e cultivado"77. A realização da justiça social dependeria antes do poder e da capacidade de ação do aparelho do Estado para intervir no sistema econômico. Mais uma vez o parentesco com o liberalismo será um ponto de partida útil para nossa argumentação, embora não pela via do direito.

O liberalismo clássico pretendia que a sociedade capitalista fosse organizada sem intervenções políticas, ou seja, simplesmente com base na economia de mercado. Mas sabe-se

\footnotetext{
${ }^{74}$ Habermas, Faktizität und Geltung, op. cit., 490.

${ }^{75}$ Idem, p. 104.

${ }^{76}$ Cf. idem, p. 490.

${ }^{77}$ Habermas, J. "Volkssouveränität als Verfahren”, op. cit., p. 618.
} 
que dificilmente, mesmo no capitalismo liberal, o mercado seria capaz de cumprir as funções de integração social simplesmente com base nas relações de troca e na forma salário. Vimos em nosso primeiro capítulo que, embora as relações de classe adotassem a forma apolítica de uma relação pura entre trabalho assalariado e capital, essa forma de socialização poderia se manter apenas se o Estado assegurasse as premissas gerais da produção capitalista. A formação do capital se realizaria com base na concorrência irrestrita dos capitais individuais, ao passo que os marcos que condicionariam essa concorrência, ou seja, as bases sociais da produção da mais-valia, não poderiam ser reproduzidos simplesmente por meios capitalistas. Marx já havia notado a necessidade do Estado que, como um não-capitalista, se imporia fortemente sobre os capitais singulares fazendo prevalecer assim uma suposta vontade capitalista que não poderia se generalizar apenas a partir das esferas da concorrência ${ }^{78}$. Desse modo, "em relação a seu elemento não-capitalista, o Estado limita a produção capitalista; em relação à sua função, serve para sua manutenção: apenas na medida em que o Estado complementa a economia, pode ser instrumental para esta"79. Essa concepção também se aplicaria para compreender a função do Estado no capitalismo tardio.

Muitos autores chamaram atenção para o fato de que o capitalismo que se estabelece na década de quarenta seria o "sucessor do capitalismo privado", com a diferença de que será o Estado que passará a assumir alguns papéis exercidos pelo capitalista privado. Como mostrou Friederich Pollock, o capitalismo de Estado herdaria necessariamente algumas funções que antes eram atribuídas ao sistema de mercado liberal. Se, por um lado, o capitalismo tardio se referia ao processo de concentração das empresas (com o surgimento de corporações nacionais e também multinacionais) e a organização do mercado de bens, de capital e de trabalho, por outro lado, remetia, sobretudo, à intervenção estatal sobre as lacunas funcionais crescentes do mercado e à sua função de coordenação e controle. $\mathrm{O}$ aumento da estrutura oligopolista de mercado marcaria o fim do capitalismo concorrencial e o início da descaracterização da forma liberal ao fazer sobressair o papel regulador de um Estado cada vez mais presente: o Estado precisaria substituir a organização liberal da divisão de trabalho garantindo, por outros meios jurídico-políticos, a manutenção dos elementos básicos da estrutura social $^{80}$.

Além da implementação de novos compromissos sociais, essa nova forma organizacional teria de continuar coordenando as necessidades sociais em termos de valores

\footnotetext{
${ }^{78}$ Cf. Draper, H. Karl Marx's theory of revolution I: The state and bureaucracy, op., cit., p. 250-262.

${ }^{79}$ Habermas, J. Legitimationsprobleme im Spätkapitalismus, op. cit., p. 74.

${ }^{80}$ Cf. Pollock, F. "State capitalism: Its possibilities and limitations". In: Studies in Philosophy and Social Science. IX, 2, 1941, p. 202-203.
} 
de uso e os recursos para satisfazê-las segundo um controle centralizado da produção e da distribuição. Isso significa, mais concretamente, não apenas assegurar a manutenção do sistema de empregos pela implementação daqueles bens coletivos apresentados anteriormente, mas antes definir as necessidades da sociedade em termos de bens de consumo, reprodução de matéria prima e maquinaria, etc. Nesse sentido, a sociedade capitalista passava a depender de um planejamento global responsável por coordenar e expandir tanto os processos de produção como também toda a distribuição do produto social adquirido, incluindo o consumo e os investimentos ${ }^{81}$. Para tanto, o Estado no capitalismo tardio não poderia se limitar a assegurar as condições gerais da produção, mas teria de intervir diretamente no processo de reprodução com a finalidade de criar primeiramente condições de valorização para o capital. Ou seja, para que pudesse intervir no processo de reprodução, o Estado precisaria criar condições de valorização do capital excedente, abater os custos e efeitos externos da produção capitalista, compensar as desigualdades da estrutura oligopolista que impediriam o crescimento e regular o ciclo da economia em seu conjunto mediante o planejamento da política social, fiscal e de conjuntura $^{82}$.

Certamente, a presença do Estado não poderia interromper definitivamente a tendência anárquica do processo de produção mercantil, e embora impusesse limites à produção capitalista, não poderia chegar a simplesmente dominar esse processo em toda sua extensão. Boa parte da produção privada continuaria orientada para o mercado e, dessa forma, seria regulada pela competição, convivendo assim com as estratégias dos oligopólios. Mas agora a função do Estado não se limitaria a assegurar as condições gerais da produção, mas ele próprio se incorporaria no processo de reprodução se convertendo em um "órgão de execução da lei do valor" $"$. Isso significa que o mercado, seguindo novamente Pollock, seria "desprovido de sua função de controle para coordenar a produção e a distribuição" 84 . Essa função teria sido substituída por um sistema de controles diretos. Nesse caso, "as liberdades de troca, de negócios e de trabalho estão sujeitas à interferência do governo em um grau tão elevado que passam a ser praticamente abolidas", desaparecendo assim, "junto com o mercado autônomo, também as chamadas leis econômicas" $" 85$. Ainda que a idéia de planejamento global encontrasse seu limite na disposição privada dos meios de produção, ou seja, na liberdade de investimento das empresas privadas, a regulação estatal passaria a ser

\footnotetext{
${ }^{81}$ Cf. idem, p. 203.

${ }^{82}$ Cf. Offe, C. "Spätkapitalismus - Versuch einer Begriffsbestimmung”, op. cit., p. 18-19.

${ }^{83}$ Habermas, J. Legitimationsprobleme im Spätkapitalismus, op. cit., p. 75.

${ }^{84}$ Pollock, F. “State capitalism: Its possibilities and limitations”, op. cit., p. 201.

${ }^{85}$ Ibidem.
} 
garantia indispensável para que se evitassem as instabilidades do mercado, assegurando dessa forma a reprodução material da sociedade ${ }^{86}$. O Estado preencheria parte substancial dos imperativos da economia ao regular o ciclo econômico em seu todo, criando e melhorando as condições para a utilização do capital excedente com "uma combinação de velhos e novos artifícios, incluindo um 'pseudo-mercado', para regular e expandir a produção e coordená-la com o consumo. O pleno emprego de todos os recursos é exigido como a principal realização no campo econômico",87.

Por se colocar como um novo órgão de execução da lei do valor e assumir a lei da concorrência pressuposta nas relações de troca, o planejamento global do Estado envolveria intervenções diretas que perpassariam as determinações econômicas da base social e alterariam sua relação com toda a superestrutura ${ }^{88}$. Primeiramente, para constituir e conservar o modo de produção, o Estado precisaria assegurar um sistema de direitos civis composto pelas instituições básicas da propriedade privada e pela liberdade de contrato. Seria fundamental, além disso, proteger o sistema de mercado de seus próprios efeitos colaterais destrutivos, como a reforma da jornada de trabalho, legislação anti-trust e pela estabilização do sistema monetário ${ }^{89}$. Além disso, o sistema jurídico teria de se adequar também a novas formas de organização empresarial, de concorrência e de financiamento que se estabelecem nesse processo específico de acumulação capitalista ${ }^{90}$. As atividades do Estado não se limitariam apenas a seu compromisso social, em que complementaria ou mesmo substituiria o mercado com base nas formas jurídicas de regulação da economia, mas possibilitariam a renovação do processo de acumulação que não poderia ser assegurado por si mesmo. Nesse caso, o planejamento criaria "novos fatos econômicos, seja proporcionando ou melhorando possibilidades de investimento (demanda estatal de bens de uso improdutivos), seja com novas formas de produzir mais-valia (organização estatal do progresso técnico-científico,

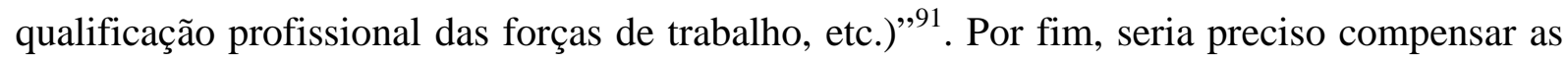
conseqüências disfuncionais do processo de acumulação que produziriam reações no campo

\footnotetext{
${ }^{86}$ Cf. Habermas, J. Legitimationsprobleme im Spätkapitalismus, op. cit., p. 52 e ss. Cf. Offe, C. "Spätkapitalismus - Versuch einer Begriffsbestimmung", op. cit., p. 19 e ss.

${ }^{87}$ Pollock, F. "State capitalism: Its possibilities and limitations", op. cit., p. 201.

${ }^{88}$ Cf. Habermas, J. Legitimationsprobleme im Spätkapitalismus, op. cit., p. 77.

${ }^{89}$ Cf. O’Connor, J. "Die fiskalische Krise des Staates". In: Narr, W- D./Offe, C. (org). Wohlfahrtsstaat und Massenloyalität, op. cit., p. 106.

${ }^{90}$ Com a criação de novas instituições no direito da empresa, na manipulação do sistema fiscal, etc. Cf. idem, p. 106-107.

${ }^{91}$ Habermas, J. Legitimationsprobleme im Spätkapitalismus, op. cit., p. 78.
} 
da política, ou seja, gerenciar as demandas de certas frações do capital, da classe trabalhadora ou de outros grupos organizados ${ }^{92}$.

Portanto, a implementação desse planejamento global seria realizada pelo poder estatal de modo que nada de essencial restasse ao funcionamento das leis do mercado ou de outras "leis" estritamente econômicas. Haveria assim uma substituição do mecanismo de mercado, que se reproduzia segundo seus próprios imperativos, pelo planejamento político e administrativo. É nesse sentido que também podemos entender a tese fundamental de uma repolitização do sistema econômico. Pois, no capitalismo tardio, os problemas freqüentemente considerados pertencentes à esfera econômica seriam tratados como problemas de administração política, ou seja, estariam sob os controles diretos do Estado. O próprio Pollock já admitia que "a substituição dos meios econômicos por meios políticos, como garantia última para a reprodução da vida econômica, modifica o caráter de toda a história do período anterior. Isso significa a transição de uma era predominante econômica para uma essencialmente política"93. A atividade política consistiria aqui no planejamento e na administração "do movimento do capital em todas as suas fases", incluindo não apenas os setores da produção pertencentes à economia privada, pois "todo elemento do processo de produção precisaria da mediação de uma atividade burocrática"94. A repolitização do capitalismo teria de ser descrita, portanto, como uma "tendência de auto-programação administrativa do processo de autovalorização do capital" $" 95$.

Certamente que o programa reformista dependia da capacidade do Estado em investir capital de uma maneira produtiva para manter o processo de acumulação juntamente com ampla política social. Seu programa se estabelecia, sobretudo, com base na distribuição do fruto do crescimento da produtividade do trabalho. O sistema administrativo precisaria satisfazer as demandas por valores de uso com os recursos fiscais disponíveis. Nesse caso, o fisco deveria arcar com os custos comuns de produção cada vez mais socializada. Habermas listas entre outros: os custos de estratégias de mercado imperialistas e que surgem por demandas de bens de uso improdutivos (armamento e corrida espacial); os custos de obras de infraestrutura que atingem diretamente a produção (sistemas de comunicações, progresso técnico-científico, formação profissional); os custos do consumo social que atingem indiretamente a produção (construção de moradias, transporte, saúde pública, tempo livre,

\footnotetext{
${ }^{92}$ Cf. Offe, C. "Tauschverhältnis und politische Steuerung. Zur Aktualität des Legitimationsproblems". In: Offe, C. Strukturprobleme des kapitalistischen Staates, op. cit., p. 48.

${ }^{93}$ Pollock, F. "State capitalism: Its possibilities and limitations", op. cit., p. 207.

${ }^{94}$ Offe, C. "Tauschverhältnis und politische Steuerung. Zur Aktualität des Legitimationsproblems”, op. cit., p. 49.

${ }^{95}$ Idem, p. 50.
} 
educação e seguro social); os custos da assistência social, em particular aos desempregados; por fim, os custos externos gerados pelas destruições do meio ambiente que resultam da produção privada $^{96}$.

Com o diagnóstico de um suposto desaparecimento das leis econômicas e do mercado autônomo, e como resultado dessa reconfiguração da economia por meio da atividade administrativa, também alguns pressupostos que sustentavam a teoria marxista das crises perderiam sua força persuasiva. Vimos que Marx pôde fundamentar sua pretensão de apreender o modelo de desenvolvimento do sistema global da sociedade (incluindo as lutas políticas e também o Estado), e interpretá-lo por meio de uma análise econômica das leis de movimento de formação do capital, justamente porque a dominação de classe se exercia na forma pretensamente apolítica da relação entre trabalho assalariado e capital. Porém, Habermas acredita que foi exatamente essa constelação que teria se modificado, pois as funções de manutenção da dominação legítima, que foram capazes de assegurar a integração social, já não poderiam ser cumpridas por meio do mercado, mas teriam de se transferir necessariamente para o sistema político-administrativo, isto é, os processos econômicos já não poderiam ser concebidos de uma forma imanente como os movimentos de um sistema econômico autoregulado: "Hoje o Estado deve cumprir funções que não podem ser explicadas com referência aos pressupostos do modo de produção nem deduzidas do movimento imanente do capital. Este movimento não se realiza mais por meio do mecanismo de mercado, tal como o concebia a teoria do valor, mas resulta das forças propulsoras de uma economia ainda em operação e de uma contra-regulação política, em que se expressa um deslocamento das relações de produção" ${ }^{\text {97 }}$.

Em primeiro lugar, a atividade estatal alterou a forma de produção da mais valia na medida em que o Estado passava a intervir no processo de acumulação do capital. Essa intervenção procurava aumentar a produtividade do trabalho por meio da produção dos bens de uso coletivos que diziam respeito à infra-estrutura material e imaterial. Nesse caso, explica Habermas, "o Estado (...) emprega agora capital para comprar a força de trabalho indiretamente produtiva dos cientistas, engenheiros, professores, etc., e transformá-la em bens de uso cada vez mais baratos da categoria em questão. Se insistirmos na estratégia conceitual dogmática e concebermos o trabalho reflexivo como trabalho improdutivo (no sentido de Marx), então a função específica desse trabalho para o processo de valorização do capital permanece desconsiderada. O trabalho reflexivo não é produtivo no sentido da produção

\footnotetext{
${ }^{96}$ Cf. Habermas, J. Legitimationsprobleme im Spätkapitalismus, op. cit., p. 88.

${ }^{97}$ Idem, p. 77.
} 
direta de mais valia; mas ele também não é improdutivo, pois assim não teria um resultado líquido para a produção de mais valia“98. Para Offe, essa mudança seria fundamental, pois uma parte substancial da força de trabalho empregada no desenvolvimento do capitalismo tardio não estaria mais organizada como mercadoria. Esse trabalho reflexivo é "concreto, não abstrato - não é uma mercadoria, e também não produz mercadoria. $\mathrm{O}$ uso de sua força de trabalho é regulada antes pelo seu resultado concreto; ela é aplicada em razão de seu valor de uso e em função do valor de uso de suas atividades, e não, tal como ocorre com o trabalho abstrato, por causa de seu valor de troca, diante do qual o valor de uso tem uma determinação apenas secundária"99. Tratar-se-iam de indicações, reforça também Habermas, de que "os conceitos clássicos fundamentais da teoria do valor-trabalho são insuficientes para a análise da política estatal na área da educação, tecnologia e ciência" ${ }^{00}$.

Em segundo lugar, em certos setores da economia monopolista, a substituição do mecanismo de mercado torna possível um compromisso político na determinação do preço da mercadoria força de trabalho. A relação apolítica entre trabalho assalariado e capital poderia ser substituída por uma distribuição política do produto social: as relações de produção seriam repolitizadas, pois a mercadoria força de trabalho estabeleceria seu preço no quadro desse possível compromisso de classe, o qual se tornou parte da própria estrutura do capitalismo tardio. Nesse caso, o salário dos trabalhadores não dependeria apenas das relações de troca no mercado, mas, sobretudo, das relações de poder político, negociação e barganha regulados pelo Estado. E uma vez que a força de trabalho constitui a unidade de medida do cálculo do valor segundo Marx, introduz-se uma dimensão política no centro da teoria do valor, tornando possível mitigar a oposição entre trabalho assalariado e capital e alcançar certo compromisso de classe, embora parcial: "O decisivo para a estrutura de classes consiste em saber se o salário real dos trabalhadores dependentes continua como sempre determinado pelas relações de troca ou se a produção e a apropriação da mais valia, em vez de dependerem apenas do mecanismo de mercado, são limitadas e modificadas pelas relações políticas"101 . A lei do valor podia expressar o duplo caráter dos processos de troca (como processos de regulação e de exploração) apenas sob a condição, preenchida de forma aproximativa no capitalismo liberal, de que a dominação de classes se exercesse por vias não políticas. Mas

\footnotetext{
${ }^{98}$ Idem, p. 81.

${ }^{99}$ Offe, C. "Tauschverhältnis und politische Steuerung. Zur Aktualität des Legitimationsproblems", op. cit., p. 31. Offe chega a afirmar que, no capitalismo tardio, as formas de socialização não apenas deixariam de ser determinadas pela forma mercadoria, mas além disso teriam de ser descritas sem referência ao conceito tradicional de trabalho. Cf. idem, p. 41-44; sobre a idéia de trabalho reflexivo, em oposição ao trabalho abstrato, ver ainda p. 58-59.

${ }^{100}$ Habermas, J. Legitimationsprobleme im Spätkapitalismus, op. cit., p. 82.

${ }^{101}$ Idem, p. 59.
} 
“como e em que medida o poder é exercido e a exploração é assegurada sobre os processos econômicos, depende hoje, contudo, das constelações concretas de poder, as quais não são mais pré-decididas por um mecanismo de mercado de trabalho capaz de se impor autonomamente" 102 .

Os dois casos sublinhados mostram que, se o princípio organizacional do capitalismo sofreu alterações significativas, a teoria marxista do valor-trabalho e os argumentos economicistas sobre a crise perdem muito em sua adequação. Mesmo que uma crise econômica pudesse ocorrer algum dia, o argumento que defendia tanto sua inevitabilidade quanto sua determinação econômica se enfraquece sensivelmente, ou seja, "não há argumentos decisivos de natureza puramente econômica para a necessidade da crise. $\mathrm{Na}$ medida em que o que ocorre na economia se torna função da atividade governamental, o exame das tendências de crise nas sociedades contemporâneas tem de levar em consideração a natureza e os limites da intervenção administrativa" ${ }^{\text {"103. }}$

É importante notar, além disso, que a pacificação do conceito de classe pelo Estado social se produziria com a condição de que o processo de acumulação, protegido pelas intervenções estatais, não diminuisse. Essa condição tornaria mais claro que as estruturas sociais que se cristalizaram com o reformismo baseado em uma economia política de tipo keynesiana, embora levasse a êxitos no plano econômico e social, não deveriam ser interpretadas como o resultado do compromisso de classe enquanto tal, como teriam entendido os teóricos do austromarxismo, principalmente Otto Bauer ou mesmo Karl Renner ${ }^{104}$. Na verdade, com a institucionalização do conflito de classes, o antagonismo social, cujo núcleo consistia na capacidade de disposição privada sobre os meios de produção da riqueza social, ver-se-ia desprovido de sua força para gerar e determinar as novas estruturas sociais dos grupos em disputa, mesmo que ainda permanecesse fundamental para a reprodução da economia. Segundo Habermas, com o capitalismo tardio, a estrutura de classes perderia sua forma historicamente apreensível, pois "a desigualdade na distribuição das compensações sociais reflete uma estrutura de privilégios que não pode mais ser derivada simplesmente das condições de classe. Isso não significa que as velhas fontes de desigualdade tenham se esgotado, pelo contrário; mas nelas não interferem somente as compensações do

\footnotetext{
${ }^{102}$ Idem, p. 76-77.

${ }^{103}$ McCarthy, T. The critical theory of Jürgen Habermas, op. cit., p. 365. "Uma teoria da crise seria convincente apenas se se apresentasse como uma teoria dos limites da administração política e econômica das crises". Offe, C. "Spätkapitalismus - Versuch einer Begriffsbestimmung", op. cit., p. 25; ver também dele, "Tauschverhältnis und politische Steuerung. Zur Aktualität des Legitimationsproblems", op. cit., p. 52 e ss.

${ }^{104}$ Cf. Marramao, G. "Entre bolchevismo e social democracia alemã: Otto Bauer e a cultura política do austromarxismo". In: Hobsbawm, E. (ed.). História do marxismo V. Rio de Janeiro: Paz e Terra, 1985. Cf. ainda Vranicki, P. Geschichte des Marxismus, Band 1, op. cit, p. 352-384.
} 
Estado de bem-estar, mas também as desigualdades de um tipo diferente. (...) Quanto mais se procura amortizar e manter latente o conflito de classes inscrito na forma privada de realização do capital, com tanta mais força passam ao primeiro plano problemas que prejudicam interesses que não podem ser interpretados diretamente como específicos de classe" ${ }^{105}$. Assim, o preço da repolitização seria, por um lado, a dissolução da identidade social e a fragmentação da consciência de classe ${ }^{106}$.

Por outro lado, os partidos, quando conseguem o poder e precisam conservá-lo, procuram assegurar simultaneamente não apenas a confiança da massa da população assistenciada pelas políticas sociais, mas também manter a confiança dos investidores privados $^{107}$. A substituição das funções do mercado pelo planejamento global do Estado não teria levado à alteração do caráter anárquico do processo econômico em seu conjunto. Segundo Habermas, "o Estado não pode intervir substancialmente na estrutura dos patrimônios sem desencadear uma 'paralização no investimento', nem consegue evitar, em longo prazo, as perturbações cíclicas do processo de acumulação, ou seja, as tendências de estagnação endogenamente produzidas, nem controlar com eficácia os substitutos para as crises, a saber, o déficit crônico do orçamento público e a inflação" ${ }^{\text {108 }}$. Pois o ciclo das crises em longo prazo e suas amplas conseqüências sociais cada vez mais graves resultariam no seu deslocamento para o interior do sistema político e no encargo crescente por parte do planejamento administrativo na manutenção da inflação e da permanente crise do orçamento público. O Estado social se vê confrontado, assim, com uma crise fiscal, pois os investimentos públicos seriam destinados não apenas para as tarefas da política social, mas também para políticas de conjuntura e de fomento do crescimento ${ }^{109}$. Em outras palavras, os efeitos disfuncionais de um crescimento econômico regido pela acumulação do capital teriam de ser absorvidos pelo Estado social sem que a forma de organização, a estrutura e o mecanismo que move a produção econômica fossem alterados. "Por essa razão", diz Habermas, "não é apenas o volume dos gastos destinados à política social que está submetido a limites fiscais, mas também o tipo de indenizações do Estado social e a organização da segurança das condições

\footnotetext{
${ }^{105}$ Habermas, J. Theorie des kommunikativen Handels, Bd. 2, op. cit., p. 513.

${ }^{106}$ Cf. Habermas, J. Legitimationsprobleme im Spätkapitalismus, op. cit., p. 56 e ss.

${ }^{107}$ Cf. Offe, C. "A democracia partidária competitiva e o Welfare State keynesiano: fatores de estabilidade e organização”, op. cit., p. 372 e ss.

${ }^{108}$ Habermas, J. Legitimationsprobleme im Spätkapitalismus, op. cit., p. 75.

${ }^{109}$ Para um resumo da teoria da crise fiscal no Estado de bem-estar social, ver O'Connor, J. "Die fiskalische Krise des Staates", op. cit., p. 104-132. Cf. também O'Connor, J. USA: A crise do Estado capitalista. Rio de Janeiro: Paz e Terra, 1977, p. 19-24.
} 
de vida têm de se ajustar à estrutura de troca, regulada pelo dinheiro e pelo poder, entre os âmbitos de ação organizados formalmente e seus entornos" ${ }^{\prime 10}$.

Cada vez mais ficariam claras as dificuldades de uma manutenção do crescimento capitalista implementada por vias intervencionistas. A maior dificuldade consistiria no fato de que a implementação de seus programas inevitavelmente esbarraria nos interesses dos investidores privados ${ }^{111}$. Naturalmente haveria mais causas para a diminuição da rentabilidade das empresas, para a redução da disposição de investir e para a queda da taxa de crescimento. "Mas as condições de valorização do capital", complementa Habermas, "são afetadas pelas políticas do Estado de bem-estar não apenas de fato, mas, sobretudo, na percepção subjetiva das empresas. Além disso, os custos crescentes dos salários e dos encargos trabalhistas aumentam a tendência para investimentos em racionalização, a qual, sob o signo da segunda revolução industrial, intensifica a produtividade do trabalho tão significativamente que torna a força de trabalho mais e mais ociosa, apesar da tendência secular para a redução da jornada de trabalho" ${ }^{\prime 12}$. Porque a falta de disposição para investimentos, a estagnação econômica, o desemprego crescente e a crise do orçamento público também podem ser relacionados aos custos do Estado de bem-estar, cada vez mais se tornam perceptíveis as limitações estruturais sob as quais o compromisso do Estado social foi criado e mantido: "Como o Estado social tem de deixar intacto o modo de funcionamento do sistema econômico, não lhe é possível exercer influência sobre a atividade privada de investimentos senão através de intervenções ajustadas ao sistema. Ele não teria de forma alguma poder para isso também porque a redistribuição de renda limita-se, no essencial, a um realinhamento horizontal dentro do grupo de trabalhadores dependentes e não toca na estrutura específica do poder de classe, especialmente na propriedade e nos meios de produção"113. E quando a lógica anárquica de autoregulação que ainda orientaria os investidores privados entra em crise e se desloca para o sistema administrativo, a socialização crescente da produção regida pelos interesses privados força o Estado a um planejamento que adotaria caminhos contraditórios. Em outras palavras, o planejamento global do Estado sobre a produção colidiria com as exigências da concorrência e da liberdade de investimento. Pois mesmo que a ampliação da capacidade de planejamento beneficiasse o capitalismo em seu conjunto, a manutenção da concorrência imporia limites a tal ampliação. "Por essa razão", diz Habermas, "o aparelho do Estado oscila

\footnotetext{
${ }^{110}$ Habermas, J. Theorie des kommunikativen Handels, Bd. 2, op. cit., p. 509-510.

${ }^{111}$ Cf. Offe, C. "Tauschverhältnis und politische Steuerung. Zur Aktualität des Legitimationsproblems", op. cit., p. 58.

${ }^{112}$ Habermas, J. "Die nachholende Revolution und linker Revisionsbedarf: Was heißt Sozialismus heute?", op. cit., p. 149.

${ }^{113}$ Idem, p. 149-150.
} 
entre uma intervenção esperada e a renúncia forçada de tal intervenção, entre uma autonomização perigosa para o sistema diante de seus endereçados e uma subordinação a seus interesses particulares" ${ }^{114}$.

Foi com base nessa incapacidade de conciliar política econômica, proteção social e organização do trabalho que Robert Castel apresentou um diagnóstico praticamente irrefutável de que o Estado social não poderia mais assegurar o status do trabalho assalariado $^{115}$. Embora dirigido às vítimas do mercado e empenhado na tentativa de consolidar o trabalho como um direito de cidadania industrial, o Estado social se limitou estrategicamente à modernização industrial competitiva, sendo incapaz de conservar a solidariedade. “Assim”, conclui Habermas, “o Estado social bem-sucedido perde o pé em uma situação na qual tem de vir a tona o fato de que ele próprio não é um 'manancial de abastança' autônomo e não pode assegurar o lugar ao trabalho como um direito civil’"116.

\section{II - O conceito do político como mero poder administrativo: A crise de legitimação no capitalismo tardio}

\section{Colonização, reificação e juridificação}

O capitalismo liberal se constituiu a partir do desenvolvimento das revoluções burguesas e, portanto, teria de se legitimar nas respectivas formas políticas da democracia liberal, principalmente com base no sufrágio universal. Para Marx, como vimos, essa democracia liberal foi entendida como mera superestrutura da sociedade capitalista de classes e não poderia assegurar a legitimidade de suas formas políticas. No caso do capitalismo tardio, com o deslocamento das relações de produção, ou seja, com a substituição das relações de troca estabelecidas com base na forma salário pelo poder da administração estatal, o Estado já não representava simplesmente uma superestrutura de relações de classe e a questão central consistiria em saber como a planificação administrativa poderia dispor de um poder legítimo. Essa necessidade de legitimação surgiria não apenas devido às novas funções assumidas pelo aparelho do Estado no capitalismo tardio, mas também em função do número de programas sociais que precisariam ser regulados administrativamente. Em outros termos, seriam as

\footnotetext{
${ }^{114}$ Habermas, J. Legitimationsprobleme im Spätkapitalismus, op. cit., p. 90.

${ }^{115}$ Cf. Castel, R. Les métamorphoses de la question sociale, op. cit, p. 705-745.

${ }^{116}$ Habermas, J. “Die nachholende Revolution und linker Revisionsbedarf: Was heißt Sozialismus heute?”, op. cit., p. 150 .
} 
próprias condições de funcionamento com as quais o poder administrativo regularia o mercado e fomentaria a justiça social que pressionariam o sistema político à legitimação ${ }^{117}$. Portanto, os problemas de legitimação no capitalismo tardio não poderiam ser reduzidos a problemas de valorização do capital, pois também dependiam da capacidade administrativa do Estado social em satisfazer as necessidades legítimas da sociedade com uma distribuição universal de valores de uso. O ponto mais importante para essa análise do capitalismo tardio consistiria na possibilidade de formular um diagnóstico que permitisse dar um passo além da ortodoxia marxista, ou seja, entender como o poder administrativo, não mais pensado meramente segundo o reflexo das desigualdades sociais da base econômica, também produziria simultaneamente uma estratificação social cujas conseqüências corresponderiam a formas de alienação e reificação impostas sobre a vida dos indivíduos e com a qual uma teoria social crítica teria de se confrontar. É preciso entender "por que, sob a coberta de um compromisso que parece ter dado bons resultados que o Estado social representa, ainda continuam se produzindo conflitos - conflitos que não se apresentam primariamente como conflitos específicos de classe, e que, não obstante, se produzem a partir de uma estrutura de classe que foi deslocada aos âmbitos de ação integrados sistemicamente" ${ }^{, 118}$.

Se nos voltarmos ao modelo da crise sistêmica elaborada por Claus Offe, podemos entender que o capitalismo tardio se estruturaria segundo três elementos fundamentais: a economia, o sistema político-administrativo e também subsistemas normativos, ou seja, legitimadores. Vimos que o aumento das interferências por parte do sistema político sobre a economia implicaria, por seu turno, uma não-correspondência direta entre trabalho assalariado e capital, por um lado, e a própria constituição das classes sociais, por outro lado. Não seria mais possível deduzir todos os conflitos sociais apenas da contradição existente no interior do sistema econômico, porque este sistema não se reproduziria mais sem as mediações administrativas. A riqueza da análise de Offe consistiria em identificar os mecanismos políticos que produziriam dimensões estruturais contraditórias da distribuição do poder nos processos de reforma. Sua análise se concentraria na lógica específica da "seletividade das instituições políticas" para lidar com os grupos de interesse em conflito administrados pelo Estado, bem como nos limites do sistema político para assegurar a legitimação de suas próprias intervenções políticas seletivas ${ }^{119}$. Offe formulou essa crise de legitimação como

\footnotetext{
${ }^{117}$ Cf. Offe, C. "Demokratische Legitimation der Planung". In: Offe, C. Strukturprobleme des kapitalistischen Staates, op. cit., p. 124.

${ }^{118}$ Habermas, J. Theorie des kommunikativen Handels, Band. 2, op. cit., p. 515.

${ }^{119}$ Cf. Offe, C. "Klassenherschaft und politisches System. Zur Selektivität politischer Institutionen", op. cit., p. 65-106.
} 
tensão entre capitalismo e democracia sob o ponto de vista da concorrência entre princípios contrários de integração social: "O que distingue as sociedades capitalistas de todas as outras não é o problema de sua reprodução, ou seja, o problema de compatibilizar integração social e integração sistêmica, mas sim o fato de abordar esse problema fundamental de todas as sociedades de modo a comprometê-las simultaneamente com duas vias de solução que se excluem logicamente entre si: com a diferenciação e a privatização da produção e com a sua socialização e politização. Estas duas estratégias se entrecruzam e se paralelizam mutuamente. Por conseguinte, o sistema se vê permanentemente confrontado com o dilema de ter de abstrair e, não obstante, não poder prescindir, das regulações normativas de ação e das referências de sentido dos próprios sujeitos. A neutralização política da esfera do trabalho, da produção e da distribuição é simultaneamente corroborada e revogada" ${ }^{20}$.

O Estado social estaria estruturalmente vinculado a medidas seletivas para organizar os interesses em conflito, sejam estes gerados pelos capitalistas privados na dinâmica do mercado ou pela expectativa dos cidadãos diante dos benefícios dos programas de bem-estar. As instituições do sistema político (parlamentos, partidos, sindicados, associações coletivas, etc.) estabeleceriam suas negociações segundo "sistemas de filtros" que selecionariam certos tipos de interesses, necessidades e motivações para incluí-los na pauta administrativa e, por conseguinte, orientar suas compensações e indenizações sociais ${ }^{121}$. Nesse sentido, a administração estatal necessariamente teria de ser entendida com base nas "contribuições positivas para a estruturação dos interesses" ${ }^{\prime 22}$. A partir de seu programa de bem-estar e de subsídios, na expansão da administração política e na possibilidade de satisfazer amplamente necessidades fundamentais (nos programas de educação, saúde, habitação, transporte, etc.), o Estado intervencionista criaria uma nova lógica de desigualdade social. Em outros termos, a organização dos interesses e os próprios potenciais de conflito no capitalismo tardio passariam para o terreno do Estado ${ }^{123}$. "O ponto importante", comenta Cohen, "consiste em que esses interesses não 'entram' simplesmente no sistema político vindos de algum outro lugar (a economia), mas são em parte constituídos pelo próprio sistema. Isso implica um sistema estratificado em três partes: (1) classes ou interesses que se desenvolvem horizontalmente por meio das relações de produção e do mercado; (2) proliferação de grupos

\footnotetext{
${ }^{120}$ Offe, C. "Unregierbarkeit”. In: Habermas, J. (org). Stichworte zur geistigen Situation der Zeit. Frankfurt/M: Suhrkamp, 1979, p. 315.

${ }^{121}$ Cf. Offe, C. "Klassenherschaft und politisches System. Zur Selektivität politischer Institutionen”, op. cit., p. 95 e ss.

${ }^{122}$ Idem, p. 96.

${ }^{123}$ Cf. Offe, C. "Political authority and class structures: An analysis of late capitalist societies". In: International journal of sociology, 1972, p. 95-96.
} 
de interesse perpassando as fronteiras das classes produzida em parte pelo sistema administrativo; e (3) áreas marginais, grupos sociais e necessidades constituídas enquanto tal pelo processo seletivo de intervenção estatal, mas sem a possibilidade de serem articulados com referência imediata ao sistema político-administrativo" ${ }^{24}$.

É dessa mesma estrutura que Habermas parte para avaliar a tensão entre democracia e capitalismo. Habermas procura especificar a democracia a partir dos limites que uma formação pública da opinião e da vontade poderiam impor diante do sistema econômico e do poder estatal. Caso contrário, a integração social em seu conjunto se reduziria ao processo de satisfação das necessidades funcionais da economia e da administração. Mas a dinâmica capitalista própria do sistema econômico se preservaria apenas quando o processo de produção se desprendesse das orientações por valores de uso. Nesse caso, o mecanismo propulsor do sistema econômico precisaria necessariamente ser protegido das restrições impostas pela interação simbólica da sociedade para que sua reprodução seguisse seus próprios imperativos, bem como das exigências de legitimação que se imporiam ao sistema administrativo. Contudo, "o sentido sistêmico específico do capitalismo pode se reduzir à fórmula segundo a qual, se for preciso, as necessidades funcionais dos âmbitos de ação de integração sistêmica têm de ser satisfeitas ainda às custas de uma tecnicização do mundo da vida" 125 .

Ora, ao se integrar no processo de reprodução, o Estado modificaria as leis econômicas determinantes do processo de valorização enquanto tal. Porém, o interesse na conservação do desenvolvimento capitalista parece colidir não simplesmente com os interesses diferenciados dos capitalistas privados, mas também com os interesses da população orientados por valores de uso. Isso significa, em outras palavras, que o Estado social precisaria simultaneamente investir na produtividade do trabalho para conservar a marcha do processo de acumulação e também assegurar a aceitação política de seus programas reformistas. O aparelho do Estado se encontraria assim diante de duas tarefas simultânes, explica Habermas: "por um lado, deve coletar a massa de impostos requerida em detrimento dos lucros e rendimentos e aplicá-la com racionalidade suficiente de modo que fosse possível evitar as perturbações no crescimento sujeitas à crise; por outro lado, o recolhimento seletivo de impostos, o modelo seletivo de prioridades reconhecido para sua aplicação e as próprias indenizações

\footnotetext{
${ }^{124}$ Cohen, J. Class and civil society: The limits of marxian critical theory, op. cit. p. 199.

${ }^{125}$ Habermas, J. Theorie des kommunikativen Handels. Band 2, op. cit., p. 507-508.
} 
administrativas devem ser implementados de modo a poder ser satisfeita a necessidade crescente por legitimação" ${ }^{126}$.

A colisão entre o imperativo do capital e o poder administrativo ocorre, segundo Habermas, na esfera pública política. A natureza política dessa esfera pública não corresponde diretamente aos mecanismos estatais de poder, mas sim à "autonomia do mundo da vida", ou seja, à interação reflexiva por meio da qual os sujeitos e grupos de interesse formam politicamente sua opinião e vontade. Contudo, do ponto de vista do programa do Estado social, a opinião pública precisa ser incorporada no modo de operar a procura por legitimação em face das políticas de bem-estar. Por um lado, a interação política apresentaria uma primeira dimensão considerada democrática, na qual a base da formação da opinião ocorreria em instâncias diferenciadas da esfera pública, manifestando-se de forma plural na vontade dos eleitores, dos partidos e das associações, etc. Habermas diz ser esse o "o primeiro elo da cadeia da formação política da vontade como base da legitimação" ${ }^{27}$. Por outro lado, o processo do acordo político pode ser considerado também como "resultado de uma procura por legitimação", como "último elo na cadeia de produção de lealdade das massas da qual o sistema político se provê para se livrar das restrições do mundo da vida" ${ }^{128}$. A dinâmica do jogo político consistiria, portanto, na pressão exercida pelos processos de formação da opinião e da vontade (ligados a interesses, normas e valores), por um lado, e na imposição de limites estabelecidos a partir da lógica de funcionamento e de organização do sistema político, pelo outro lado.

Mas a amplitude do papel exercido pelo Estado na dinâmica do acordo político seria tão grande a ponto de a lógica de reprodução sistêmica determinar em grande medida a reprodução simbólica da integração social e, conseqüentemente, do processo político de legitimação $^{129}$. A autodeterminação política dos cidadãos seria incorporada antes em um processo de garantia da lealdade das massas, no qual o Estado seria capaz de gerar expectativas de comportamento determinadas pelos programas de compensações sociais e, além disso, pela capacidade de selecionar os temas colocados publicamente na arena política. O poder administrativo se utilizaria de filtros estruturais para ter acesso à esfera pública política, para controlar burocraticamente as estruturas de comunicação pública e manipular com certa eficácia os fluxos de informação. O programa do Estado social procuraria assegurar

\footnotetext{
${ }^{126}$ Habermas, J. Legitimationsprobleme im Spätkapitalismus, op. cit., p. 88-89.

${ }^{127}$ Habermas, J. Theorie des kommunikativen Handels. Band 2, op. cit., p. 509.

${ }^{128}$ Ibidem.

${ }^{129}$ Cf. Edelman, M. "Die symbolische Seite der Politik". In: Narr, W- D./Offe, C. (org). Wohlfahrtsstaat und Massenloyalität, op. cit., p. 307-322.
} 
a lealdade das massas adotando tanto uma via positiva como uma seletiva: positivamente através da expectativa de cumprimento dos programas do Estado social, seletivamente pela exclusão de determinados temas e contribuições da discussão pública ${ }^{130}$.

É desse modo que a democracia seria composta no quadro do Estado social em grande medida pelo o que Habermas chamou de "autoapresentação simbólica das elites políticas na esfera pública" ${ }^{\prime 131}$. Para que a manutenção do acordo político pudesse ser operacionalizada por meios administrativos, as elites políticas se distanciariam dos processos reais de tomadas de decisão ancorados em amplos processos de formação política da opinião e da vontade. A participação política passaria a ser reduzida ao papel de eleitor e a dinâmica do jogo político à estratégia partidária, de modo que a decisão do voto serviria antes como uma espécie de processo de recrutamento daqueles que estariam no comando: "à medida que os partidos políticos se tornaram estatizados, à medida que sua substância democrática foi solapada em seu cerne, eles passaram a agir a partir da perspectiva do poder administrativo, no qual assumiram posições de poder que querem preservar. Assim, a função que primeiramente precisam realizar, a saber, a articulação e mediação da formação política da opinião e da vontade, é desempenhada somente na forma de campanhas publicitárias" ${ }^{132}$. E embora o programa do Estado social contivesse paradoxalmente elementos constitutivos de uma legitimação verdadeiramente democrática, na qual as implementações institucionais poderiam estar ancoradas no acordo político amplo e reflexivo, sua efetivação produziria apenas lealdade das massas e uma "aclamação aparentemente democrática"133. A implementação dos direitos políticos para o estabelecimento de uma democracia de massas siginificaria assim não simplesmente a generalização positiva do papel do cidadão, mas também a segmentação desse papel em relação aos processos efetivos de tomada de decisão absorvidos pelo sistema político.

Porém, esse papel de cidadão não seria vazio apenas de conteúdos participativos. A participação política, que juridicamente já havia sido possibilitada com a institucionalização da autonomia pública do cidadão, tal como mostrou Marshall, também se neutralizaria na medida em que as expectativas criadas em torno das indenizações compensatórias implementadas pelas burocracias do Estado social engessariam o sentido da autodeterminação

\footnotetext{
${ }^{130}$ Cf. Habermas, J. Theorie des kommunikativen Handels. Band 2, op. cit., p. 509.

${ }^{131}$ Ibidem. Ver também Habermas, J. Strukturwandel der Öffentlichkeit, op. cit., \$2.

${ }^{132}$ Habermas, J. "Ein Gespräch über Fragen der politischen Theorie”, op. cit., p. 141.

${ }^{133}$ Narr, W- D./Offe, C. (org). Wohlfahrtsstaat und Massenloyalität, op. cit., p. 28.
} 
política, reduzindo-a ao gozo passivo de direitos concedidos paternalisticamente ${ }^{134}$. Tal neutralização do papel de cidadão ocorreria como conseqüência do preço que o Estado social pagaria com "a moeda de valores de uso" que os cidadãos recebem enquanto meros clientes da burocracia de bem-estar. Ser um mero cliente significaria, nesse contexto, comportar-se segundo consumidores que desfrutam as vantagens dos programas sociais e que se conformam que sua participação política seja volatizada em abstração e desprovida de efetividade. Nesse sentido, assim como a carga do trabalho alienado é compensado pelo papel de consumidor, também "as secuelas da institucionalização de um modo alienado de codeterminação são desviadas para o papel de cliente" ${ }^{\text {"135. }}$.

Porque dispõe de um número de compensações que permitem ser distribuídas em um padrão paternalista e tecnocrático de discussões ritualizadas, o Estado social procura paradoxalmente impedir que as estruturas reificantes do trabalho abstrato e da intervenção estatal criem novamente efeitos destrutivos sobre o contexto de vida dos indivíduos. Pois tais compensações dependeriam da manutenção do crescimento capitalista assegurada por mais intervencionismo estatal. Nesse caso, a administração política da dinâmica do capitalismo se efetivaria simultaneamente como desenvolvimento e como resultado de uma expansão e densificação dos processos de socialização que os sistemas econômico e político impõem sobre a sociedade a partir de âmbitos de ação formalmente organizados. A interação social simbolicamente mediada seria pressionada pelo crescimento desse complexo sistêmico e cada vez mais impelida a se reproduzir conforme os padrões do mercado e da burocracia: de um lado, o orçamento privado se converteria em consumo de massa; de outro lado, as relações de clientela se transfeririam para a organização burocrática dos programas sociais ${ }^{136}$.

Se concebermos a lógica do poder administrativo e os processos de legitimação ancorados na esfera pública segundo a distinção entre sistema e mundo da vida, poderemos descrever o processo por meio do qual o sistema político simplesmente extrai lealdade das massas da esfera pública como um processo de colonização do mundo da vida pelos sistemas $^{137}$. Tratar-se-ia de identificar a extensão com que o sistema político-administrativo transformaria o processo de formação política da opinião e da vontade em parte de sua própria lógica de autoconservação. O modelo que Habermas teria em mente para pensar a colonização do mundo da vida seria o da análise de Marx da intromissão gradual do modo de produção

\footnotetext{
${ }^{134}$ Cf. Ewald, F. L'État providence. Paris, 1986, p. 88-95; e Castel, R. Les métamorphoses de la question sociale, op. cit., p. 601-620.

${ }^{135}$ Habermas, J. Theorie des kommunikativen Handels. Band. 2, op. cit., p. 515.

136 Cf. idem, p. 516. Cf. também Offe, C. "Das politische Dilemma der Technokratie". In: Offe, C. Strukturprobleme des kapitalistischen Staates, op. cit., p. 107 e ss.

${ }^{137}$ Cf. Habermas, J. Theorie des kommunikativen Handels. Band 2, op. cit., p. 489-547.
} 
capitalista sobre as esferas da vida, embora a subsunção do trabalho vivo sob a forma da mercadoria fosse agora uma expressão teoricamente mais simplificada dos processos de reificação não limitados à experiência de mercantilização da força de trabalho ${ }^{138}$.

Habermas pretende descrever a colonização do mesmo modo como Marx havia analisado o processo de abstração real ${ }^{139}$. Ao utilizar este processo, Marx se referia à dimensão do trabalho industrial alienado e aos antagonismos de classe, dando continuidade a um discurso da modernidade formulado agora segundo o surgimento de contextos funcionalmente autônomos que se desacoplam da dimensão de interações simples e de formas organizacionais do trabalho pré-capitalista e das formas de dominação pré-modernas. Com a emergência do capitalismo, surgiria um sistema econômico que pôde ser descrito como um sistema que regula acordos comerciais e os intercâmbios com outras dimensões sociais (como a da família e do Estado) segundo seus próprios imperativos. Vimos também que, com a análise da mercadoria força de trabalho, Marx descreveria uma operação de neutralização progressiva por meio da qual os imperativos do sistema econômico, tornados abstratos e indiferentes diante dos contextos de vida dos trabalhadores, se constituiria como trabalho abstrato. Segundo Habermas, "Marx esclarece esse processo de abstração real com a coisificação de contextos de ação integrados socialmente, que ocorre quando as interações não podem mais ser coordenadas segundo normas e valores, ou de acordo com processos de entendimento, mas sempre com base no medium do valor de troca" ${ }^{" 140}$. Nesse caso, os participantes se interessariam primeiramente somente nas conseqüências de suas ações e se comportariam adotando atitudes objetivadoras, transformando assim tanto as relações sociais intersubjetivas como as intrapsíquicas em relações instrumentais. Segundo Habermas, essa "transformação da força de trabalho concreta em abstrata significa um processo tanto de reificação da vida social como da própria vida individual" ${ }^{\text {141 }}$.

Habermas identificaria a colonização, todavia, não somente a partir do momento em que o processo de produção passava a se ajustar ao mercado de trabalho, mas também quando o aparelho do Estado passava a se vincular à produção e começava a se expandir a todos os âmbitos da administração. A institucionalização do trabalho assalariado bem como das relações entre Estado fiscal e cliente, que decorreria da relação entre cidadão e as burocracias estatais, seriam ambas experimentadas como colonização de formas tradicionais de trabalho e

\footnotetext{
${ }^{138}$ Cf. Habermas, J. "Entgegnung”. In: Honneth, A./Joas, H. (org). Kommunikatives Handeln. Frankfurt/M: Suhrkamp, 2002, p. 389.

${ }^{139}$ Cf. Lohmann, G. Indiferenz und Gesellschaft, op. cit., capítulo III.

${ }^{140}$ Habermas, J. Theorie des kommunikativen Handels, Bd. 2, op. cit., p. 494.

${ }^{141}$ Ibidem. Cf. Honneth, A. Verdinglichung: Eine anerkennungstheoretische Studie, op. cit., capítulo I; também Lohmann, G. Indiferenz und Gesellschaft, op. cit., capítulos V e VIII.
} 
de interações sociais específicas de contextos de vida ainda intencionalmente estruturados. Desse modo, não apenas os imperativos da economia, mas também a lógica funcionalista do Estado penetraria na reprodução simbólica do mundo da vida. Em linhas gerais, a colonização aconteceria quando as relações de troca entre sistema e mundo da vida fossem caracterizadas segundo papéis pré-determinados (como vimos em relação à atividade laboral no mercado de trabalho, às relações de clientela com as burocracias estatais e à participação formal nos processos de legitimação), principalmente quando o trabalho abstrato e a participação dos cidadãos limitada ao voto fossem aceitos pelos próprios concernidos em troca das compensações oferecidas pelo sistema. Por essa razão, o caso modelo da colonização no capitalismo tardio consistiria na transformação dos cidadãos em meros destinatários das burocracias estatais, uma vez que o programa baseado em compensações realocaria as esperanças de autorealização e de autodeterminação apenas nos papéis de consumidor e de cliente.

Habermas pretende assim dar continuidade à descrição dos "processos dolorosos de dissolução e "abstração"” do ponto de vista "daqueles que vêem a si mesmos como tendo sido colocados à distância dessas mudanças e excluídos dessas novas realidades, objetificadas e organizacionalmente estruturadas" ${ }^{142}$. As compensações do Estado de bem-estar resultariam em "paternalismo", em uma "supervisão custodial", em "privatismo civil", na medida em que os cidadãos fossem transformados em consumidores privados e em clientes dos programas sociais. Habermas utiliza também o termo weberiano "perda de liberdade", dando a entender que as consequiências das intervenções unilaterais do Estado criariam aquela "gaiola de ferro" (stahlhartes Gehäuse) a que Weber já havia se referido ${ }^{143}$. A regulação estatal implicaria uma densa malha de normas jurídicas e de intervenções administrativas que recobririam crescentemente o cotidiano das pessoas. Não seria por acaso que o poder administrativo foi caracterizado por muitos como um instrumento de normatização forçada, vigilância e, no limite, brutalidade reificante. Por essa razão, a crítica de Marx à exploração material e ao empobrecimento precisaria ser deslocada às deformações de uma sociedade administrada, controlada e protegida ${ }^{144}$.

\footnotetext{
${ }^{142}$ Habermas, J. "Entgegnung”, op. cit., p. 385.

${ }^{143}$ Cf. Weber, M. Die protestantische Ethik und der Geist des Kapitalismus, op. cit., p. 203-204; cf. também Habermas J. Theorie des kommunikativen Handels. Band 1, op. cit., p. 332-366.

${ }^{144}$ Tal seria o diagnóstico de fundo em Adorno, T. W./Horkheimer, M. Dialektik der Aufklärung. In: Adorno, T. W. Gesammelte Schriften 3. Frankfurt/M: Suhrkamp, 1997; Foucault, M. Em defesa da sociedade. São Paulo: Martins Fontes, 1999, aulas de 7 e 14 de janeiro e17 de março, todas de 1976. Para uma visão geral, ver Honneth, A. Kritik der Macht: Reflexionsstufe einer kritischen Gesellschaftstheorie. Frankfurt/M: Suhrkamp, 1986.
} 
Esse processo de colonização do mundo da vida no capitalismo tardio foi caracterizado por Habermas também segundo sintomas de reificação. Vimos que a crítica da economia política se concentraria principalmente nos processos em que ocorreria a troca da força de trabalho por salário, fazendo com que Marx circunscrevesse os sintomas de reificação ao mundo do trabalho. Teria sido, sobretudo, Lukács o responsável por retomar o processo que Marx havia descrito como "fetichismo da mercadoria" ao explicar a forma com que as relações sociais capitalistas aparentam como se fossem relações entre coisas em função do domínio da troca de mercadorias ${ }^{145}$. Mas além disso, Lukács ligaria a perspectiva da crítica da economia política à teoria da racionalização de Weber. Como causa social para o aumento da reificação, ele se concentraria na ampliação da troca de mercadorias, a qual se tornou o modo dominante de ação com o estabelecimento das sociedades capitalistas. O conceito de reificação estaria nesse momento sendo ampliado e generalizado para os contextos e hábitos sociais mais comuns. Lukács fundamentaria essa generalização com base em dois importantes argumentos: por um lado, o argumento funcionalista mostraria que seria necessário para a expansão do capitalismo que todas as esferas da vida - não somente as esferas de ação puramente econômicas - fossem assimiladas ao padrão de ação da troca de mercadorias; e, por outro lado, apoiando-se em Weber, o processo de racionalização que se intensifica na dimensão da troca de mercadorias conduziria a um aumento de atitudes racionais com respeito a fins que abrangeria âmbitos sociais que até então eram dominados pelas esferas tradicionais ${ }^{146}$. É por essa razão que Lukács pôde afirmar a tese de que no capitalismo a reificação se expandiria a ponto de se transformar em uma "segunda natureza" "147.

Habermas retomaria essa tese de uma racionalização unilateral identificada por Lukács: o crescimento capitalista continuaria provocando conflitos no mundo da vida, porém seria sempre acompanhado de uma expansão e de um adensamento do complexo burocrático, principalmente quando as interações sociais simbolicamente mediadas fossem redefinidas em função dos papéis de consumidor e cliente, ou seja, quando fossem assimiladas pelos âmbitos de ação sistêmica. No entanto, Habermas não acredita que o processo de modernização social no capitalismo tardio ainda permitiria vincular os sintomas da reificação a efeitos específicos de classe. Em vez de ligar os efeitos colaterais do processo de racionalização à força estruturadora do conflito de classes, tal como o fez Lukács, ele pretenderia entender a

\footnotetext{
${ }^{145}$ Cf. Lukács, G. "Die Verdinglichung und das Bewußtsein des Proletariats", op. cit., p. 257 e ss. Cf. Nobre, M. Lukács e os limites da reificação, op. cit., capítulo 1.

${ }^{146}$ Cf. Lukács G. "Die Verdinglichung und das Bewußtsein des Proletariats", op. cit., p. 290 e ss. Ver também Habermas, J. Theorie des kommunikativen Handels. Band. 1, op. cit, capítulo IV.

${ }^{147}$ Cf. Lukács, G. "Die Verdinglichung und das Bewußtsein des Proletariats", op. cit., p. 260.
} 
modernização como produção da reificação sobre âmbitos de ação estruturados comunicativamente. "O que agora me interessa", diz Habermas, "é apontar como surgem novos efeitos reificantes não especificamente deriváveis da estrutura de classes e por que tais efeitos, filtrados e diferencialmente dispersos pelo padrão de desigualdade social, se fazem sentir hoje, sobretudo, nos âmbitos de ação estruturados comunicativamente, ou seja, fora da esfera da produção"148. Por conseguinte, a reificação no capitalismo tardio, uma vez reformulada segundo as categorias habermasianas, não poderia mais ser pensada a partir de uma teoria da consciência de classe. Os fenômenos que Weber analisou fazendo referência às tendências de burocratização não caracterizariam posições de classe determinadas, mas sim a totalidade da modernização social. A reificação se voltaria antes aos processos de empobrecimento e de fragmentação da consiência cotidiana: "em vez de perseguir os vestígios deixados por uma consciência revolucionária, ela teria de investigar as condições de um reacoplamento da cultura racionalizada com uma comunicação cotidiana que precisa de tradições vivas que a nutrem"149.

Ao expor o processo de colonização do mundo da vida por parte dos sistemas, Habermas apresentaria, por fim, também um diagnóstico caracterizado pelo o que chamou de ondas de juridificação das relações sociais ${ }^{150}$. Para compreender o conceito de juridificação (Verrechtlichung) seria preciso partir novamente do projeto de universalização dos direitos civis, passando pelos direitos de participação política, chegando por fim à sua complementação na forma dos direitos sociais. $\mathrm{O}$ aspecto positivo desse processo, ou seja, a ampliação dos espaços de autodeterminação e autorealização, seria obtido pelas respectivas ondas de juridificação em cada um dos estágios descritos por Marshall e tratados acima. Entretanto, a juridificação apresentaria também um lado paradoxal, pois, cada vez que o direito assumisse uma forma jurídica mais abrangente, implementaria simultaneamente a substituição de um âmbito de interação social reflexiva pela integração sistêmica, pelas relações sociais formalmente organizadas constitutivas do direito moderno. A divisão sugerida por Habermas para descrever os passos em que ocorreriam tais substituições incluiria o Estado burguês, o Estado de direito, o Estado democrático de direito e, finalmente, o Estado social e democrático de direito. Vamos considerar rapidamente aqui apenas as duas últimas e descrever como Habermas as entende como um desacomplamento entre sistema e mundo da vida e como conflito deste com a dinâmica própria dos sistemas autonomizados.

\footnotetext{
${ }^{148}$ Habermas, J. Theorie des kommunikativen Handels. Band. 2, op. cit., p. 513.

${ }^{149}$ Idem, p. 522.

${ }^{150}$ Cf. idem, p. 522-547. Cf. também Peters, B. Rationalität, Recht und Gesellschaft, op. cit., p. 155-166; e Lohmann, G. Indiferenz und Gesellschaft, op. cit., capítulo VI.
} 
Um traço característico do Estado de direito consistia em se apoiar, como vimos anteriormente, em uma noção de direito formulada como direito privado. A passagem ao Estado democrático de direito implicaria ainda expandir tais direitos privados concedendo aos cidadãos também os direitos de participação política. Seriam consideradas válidas agora apenas aquelas leis que poderiam contar com o assentimento de todos os cidadãos e ser garantidas segundo a participação democrática. Para que fossem consideradas democráticas, a exigência de validade das leis precisaria ser satisfeita segundo um procedimento que ligasse a legislação tanto a processos de decisão parlamentar como à deliberação pública: “a juridificação do processo de legitimação é implementada na forma do direito de voto, universal e igual, e do reconhecimento da liberdade de organização para as associações e partidos políticos" ${ }^{\prime 151}$. É verdade que, com a constitucionalização e democratização de uma dominação burocrática que se apresentava inicialmente em uma forma absolutista de governo, pareceria indubitável o caráter emancipatório dessa onda de juridificação especificada pelas normatizações do Estado democrático de direito. O Estado social representaria uma juridificação dessa garantia da liberdade.

Os processos de juridificação no Estado social estariam ligados à sua própria universalização dos direitos civis: a garantia da liberdade incluiria a regulação de matérias substantivas, como a limitação do tempo de trabalho, liberdade de organização sindical, direito a um salário mínimo, seguro social, etc. Procuramos insistir que, nesses casos, o programa reformista se caracterizaria pelo processo de juridificação de um mundo do trabalho que inicialmente estava submetido ao poder onipotente de disposição e autoridade organizacional dos proprietários dos meios de produção. A ampliação do direito significaria, nesse caso, a conquista de um equilíbrio de poder dentro de um âmbito de ação já constituído juridicamente. Contudo, essa última onda de juridificação ressaltaria também os efeitos colaterais da ampliação dos âmbitos organizacionais do direito moderno. Ela mostraria que "a política do Estado social possuiu desde o início o caráter ambivalente de uma garantia da liberdade e privação de liberdade" ${ }^{\text {152 }}$. A primeira onda de juridificação, constitutiva da relação entre trabalho assalariado e capital, devia sua ambivalência a uma contradição entre o sentido socialmente emancipatório das normas do direito privado burguês, por um lado, e suas repercussões sociais repressivas sobre aqueles que se viam forçados a oferecer sua força de trabalho como mercadoria, por outro. A rede de garantias que o Estado social passaria a oferecer teria precisamente o objetivo de absorver os efeitos externos dos processos de

\footnotetext{
${ }^{151}$ Habermas, J. Theorie des kommunikativen Handels. Band. 2, op. cit., p. 529.

${ }^{152}$ Idem, p. 531.
} 
produção baseados no trabalho assalariado. Porém, quanto mais rígida se torna essa rede, mais surgiriam outros tipos de ambivalência. Ou seja, os próprios meios com que se garantiria a liberdade colocariam em perigo a autonomia dos cidadãos com os programas do Estado social, pois o sucesso de suas políticas reformistas, alcançado pela implementação burocrática e pela satisfação monetária assegurada pelos direitos sociais, resultaria em intervenções reestruturadoras no contexto de vida dos beneficiários.

Muitos autores criticaram também certas características do sistema jurídico do Estado social, formulando um diagnóstico sobre uma crise geral de seu modelo ${ }^{153}$. Com tais fenômenos de crise, Habermas estaria assim oferecendo uma análise própria para entender tal diagnóstico fundamentalmente segundo interferências ou incompatibilidades que acompanhariam as sociedades capitalistas e que estariam já presentes em sociedades liberais e se tornariam agudas no Estado social ${ }^{154}$. Tratam-se, nos termos de Bernhard Peters, de “determinados processos e estruturas básicas no âmbito da economia, do Estado e do direito que interferem nas interações sociais, nas formas de vida e nas formas de ordenação social em que identidades individuais e coletivas são formadas e as fontes sociais e culturais são reproduzidas, tais como solidariedade, motivações morais e padrões interpretativos, etc."155. Desssa perspectiva, a crítica a determinadas formas de juridificação decorreria da análise da colonização do sistema econômico e político, pois "o direito moderno forma um pressuposto institucional do capitalismo moderno" ${ }^{156}$. Sendo assim, as contradições estruturais do sistema econômico levariam necessariamente a uma expansão da regulação jurídica e, por conseguinte, produziriam distúrbios nos processos de reprodução cultural e interação social, os quais teriam de ser novamente tratados segundo meios jurídico-políticos que produziriam mais intervenções, e assim por diante ${ }^{157}$.

\footnotetext{
${ }^{153}$ Cf. Teubner, G. (org.). Dilemmas of law in the welfare state. Berlin/New York, 1985, principalmente a introdução. Também o movimento do Critical Legal Studies foram importantes para tal diagnóstico. Neste caso, ver Joerges, C./Trubek, D. (org.). Critical Legal Thought: An American-German Debate. ZERP, Band 7, 1989, também a introdução.

${ }^{154} \mathrm{Com}$ as ondas de juridificação, Habermas se juntaria a autores como Marx, Weber, Polany, Allain Touraine ou Claus Offe, os quais seriam responsáveis por apresentar o que Herbert Kitschelt chamou de teorias da interferência. Cf. Kitschel, H. “Materiale Politisierung der Produktion”. In: Zeitsschrift für Spziologie, 14, 1985, p. 200 e ss.

${ }^{155}$ Peters, B. Rationalität, Recht und Gesellschaft, op. cit., p. 161.

${ }^{156}$ Ibidem.

${ }^{157}$ Em Facticidade e validade, de 1992, Habermas mantém em suas análises o diagnóstico negativo da juridificação criada, principalmente, pelas políticas do Estado social. Além de explorar o lado emancipatório do direito moderno, a retomada do direito nessa obra ainda atribui um lugar para uma reflexão sobre tendências de juridificação. Como veremos no último capítulo, Habermas se corrige apenas em um ponto, na medida em que deixa de considerar a juridificação como consequência inevitável do Estado de bem-estar social. Cf. Habermas, J. Faktizität und Geltung, op. cit., p. 502. Cf. também Repa, L. "Direito e teoria da ação comunicativa". In: Nobre, M./Terra, R. Direito e democracia: Um guia de leitura de Habermas. São Paulo: Malheiros, 2008, p. 5571.
} 
Os direitos sociais, embora concedidos como direitos individuais, cobrem matérias gerais que, na maioria dos casos, precisariam ser cada vez mais especificadas. "A situação que necessita de regulação, ancorada no contexto de uma história de vida e de uma forma de vida concreta", comenta Habermas, "tem de ser submetida a uma violenta abstração, não apenas para poder ser tipificada juridicamente, mas também para poder ser tratada administrativamente. As burocracias, encarregadas de fazer as prestações, procedem de forma muito seletiva e escolhem apenas os casos socialmente necessários que podem ser tratados com os procedimentos jurídicos próprios da dominação burocrática sob a assimilação juridicamente fictícia dos prejuízos a serem indenizados"158. A forma de tratamento meramente administrativo, realizado sempre por especialistas e selecionado pelas burocracias, entraria necessariamente em contradição com as iniciativas autônomas dos cidadãos. Cada caso necessitado de regulação seria assim tipificado pela lógica do sistema jurídico de modo a prescindir de ampla tematização pública: “com a organização do exercício de liberdades cidadãs, as possibilidades de uma formação espontânea da opinião pública e de uma formação discursiva da vontade coletiva ficam limitadas consideravelmente pela segmentação do papel de eleitor, pela concorrência entre as elites dos partidos, pela estrutura vertical dos processos de formação da opinião pública dentro dos aparelhos partidários burocraticamente incrustrados, pela autonomização das corporações parlamentares, pelo poder estrutural incrustrado nos mecanismos de comunicação, etc" ${ }^{159}$. E quando fosse necessário questionar a legitimidade de uma norma jurídica, bastaria em muitos casos apelar para a produção formalmente correta da lei, sentença ou ato administrativo.

Além do engessamento da participação política, a tendência de juridificação se impõe também quanto mais ficam submetidos ao controle o tempo livre, a cultura, o lazer, etc., incluíndo as leis da economia de mercado que definem o consumo de massas; quanto mais manifestamente as estruturas da família burguesa se acomodam aos imperativos do sistema ocupacional; e quanto mais a escola e instituições de ensino assumem a função de distribuir de antemão as oportunidades profissionais e mesmo existenciais, etc ${ }^{160}$. Segundo Habermas, "na medida em que o Estado social vai mais além do que a pacificação dos conflitos de classe que se apresenta imediatamente na esfera da produção, estendendo sobre os âmbitos privados de existência uma rede de relações de clientela, com tanto mais força surgem os esperados efeitos colaterais patológicos de uma juridificação que simultaneamente significa uma

\footnotetext{
${ }^{158}$ Habermas, J. Theorie des kommunikativen Handels. Band. 2, op. cit., p. 532.

${ }^{159}$ Idem, p. 535

${ }^{160}$ Cf. Idem, p. 540 e ss.
} 


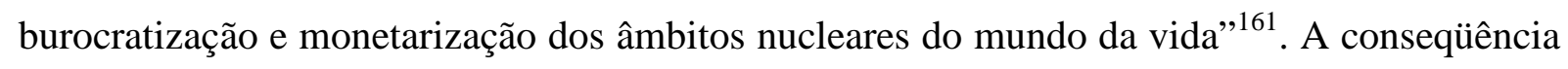
da ampliação da racionalidade instrumental, própria da reprodução sistêmica, seria a uniformização da identidade coletiva, da alienação individual e do perigo de anomia social ${ }^{162}$.

Ora, quando juntamos o lado substancial e o lado metodológico do programa socialdemocrata, viria à tona o preço da orientação reformista, do objetivo das políticas compensatórias e dos meios de sua realização. Primeiramente, ainda que tais políticas procurassem humanizar e contrabalançar os riscos básicos do trabalho assalariado, seu programa não conseguiria fugir da meta do pleno emprego, limitando-se a indenizar o cidadão enquanto cliente da burocracia com pretensões de direito e assegurar seu papel de consumidor de bens de massa com poder de compra. Os potenciais emancipatórios seriam antes bloqueados pela estratégia de uma pacificação do mundo do trabalho que orientava as compensações do Estado social. Contudo, sem esse núcleo substantivo de seu programa, o Estado social não poderia manter o sistema político se não pretendesse assegurar uma necessária forma de autolegitimação. Pois o mundo do trabalho precisou ser instrumentalizado pelo sistema político para a produção de compromissos entre os grupos em disputa. Como não poderia se afastar por completo das orientações por valores de uso por parte dos cidadãos, o sistema político mobilizaria estrategicamente os programas sociais como "ofertas de legitimação passiveis de verificação"163. Além disso, em relação ao processo político, o reformismo que segue o caminho das intervenções estatais faria com que a formação política da vontade se deslocasse para um sistema político em expansão que se programa a si mesmo, adquirindo autonomia em relação às fontes democráticas de sua legitimação, limitando assim o processo de legitimação à autoregulação administrativa ${ }^{164}$. Segundo Habermas, essa expansão da racionalidade administrativa geraria a crise de legitimação, uma vez que, sem uma formação discursiva da opinião e da vontade que tematizasse publicamente conteúdos e normas imprescindíveis à reprodução social, não seria possível criar ou manter estruturas normativas legitimadoras meramente com meios administrativos $^{165}$. Embora possamos reconhecer diversas conquistas históricas do Estado social, é preciso reconhecer, além disso, um unilateralismo específico desse projeto em seu todo. Seus programas foram implementados em larga escala por meio do poder da burocracia para que suas intervenções ganhassem força de lei, isto é, lealdade das massas. Mas com isso,

\footnotetext{
${ }^{161}$ Idem, p. 534.

${ }^{162}$ Cf. idem, p. 566-574.

${ }^{163}$ Idem, p. 510.

${ }^{164}$ Cf. Offe, C. "Demokratische Legitimation der Planung”. op. cit., p. 123-151.

${ }^{165}$ Cf. Habermas, J. Legitimationsprobleme im Spätkapitalismus, op. cit., p. 70 e ss.
} 
"não foi o Estado social que se revelou uma ilusão", diz Habermas, "mas a expectativa de poder realizar formas emancipadas de vida através de meios administrativos"166.

Entre o paradigma revolucionário e o reformista podemos notar agora papéis inversos atribuídos ao Estado: no primeiro caso, "a emancipação social deveria ser alcançada pela via de uma revolução política que tomaria posse do aparelho do Estado apenas para desmantelálo"; ao passo que, no segundo caso, "a pacificação social seria realizada apenas segundo a via das intervenções do Estado social" ${ }^{167}$. A falta de Estado naquele resultava na desconsideração de uma preocupação com a institucionalização da liberdade e no desprezo em analisar os obstáculos e potenciais dos novos conflitos sociais no quadro das democracias de massa próprias do Ocidente capitalista. Já a concepção social-democrata foi "sugada por um aparelho estatal em expansão (...) Deste modo, o outro lado de um Estado social relativamente bem-sucedido consiste em uma democracia de massas que passa a assumir os traços de um processo de legitimação regulado administrativamente. A tal processo corresponde, no âmbito programático, a resignação - tanto a conformação diante do escândalo de um destino natural imposto pelo mercado de trabalho, quanto a renúncia de uma democracia radical"168.

A social-democracia cada vez menos poderia manter a idéia de um processo que simplesmente passaria do mercado à democracia: teria de pagar um preço alto aprendendo "a viver com as conseqüências normativas indesejáveis do crescimento capitalista - e também com os riscos do mercado de trabalho, riscos que, específicos do sistema, podem ser social e politicamente 'amortecidos', mas não afastados"169. Os sindicatos e partidos reformistas que operaram no quadro de Estado democrático de direito se frustraram ao tentar concretizar o compromisso do Estado de bem-estar social, ou melhor, tiveram que se contentar com uma simples adaptação da herança liberal-burguesa e, como insiste Habermas, "renunciar ao cumprimento das promessas de uma democracia radical" ${ }^{\text {"170 }}$. Assim, o reformismo socialdemocrata não teria notado que uma contradição poderia habitar no interior do projeto do Estado social: os fins emancipatórios, visando criar e manter formas de vida estruturadas igualitariamente, garantindo a liberdade de movimentos para a autonomia e individuação de sujeitos socializados, não poderiam ser diretamente alcançados "pela transposição júridico-

\footnotetext{
${ }^{166}$ Habermas, J. “Die nachholende Revolution und linker Revisionsbedarf: Was heißt Sozialismus heute?”, op. cit., p. 192. Cf. Melo, R. “A crítica de Habermas ao paradigma ,produtivista' como orientação emancipatória da esquerda”. In: Cadernos de filosofia alemã, 10, 2007, p. 97-112.

${ }^{167}$ Habermas, J. "Volkssouveränität als Verfahren”, op. cit., p. 618.

${ }^{168}$ Idem, p. 619.

${ }^{169}$ Habermas, J. “Die nachholende Revolution und linker Revisionsbedarf: Was heißt Sozialismus heute?”, op. cit., p. 192.

${ }^{170}$ Habermas, J. “Volkssouveränität als Verfahren”, op. cit., p. 618.
} 
administrativa de um programa político. A produção de novas formas de vida está além das forças de que o medium poder dispõe" ${ }^{, 171}$.

2. Para uma nova divisão de poderes na dimensão da integração social:

Valor de troca, poder administrativo e solidariedade

Apesar de a presença central do Estado na economia tornar possível vislumbrar uma forma democrática de organização do capitalismo tardio, muitos autores apontaram para o seu exato oposto. Como já havia alertado Pollock, o capitalismo de Estado poderia assumir uma forma democrática ou totalitária: no primeiro caso, o Estado é “controlado pelo povo. Está baseado em instituições que não permitem que a burocracia transforme sua posição administrativa em um instrumento de poder possibilitando que a base de um sistema democrático se transforme em um sistema totalitário"172; no segundo caso, porém, "o Estado é um instrumento de poder de um novo grupo dominante, que emergiu dos interesses daqueles dotados de maior poder, do último escalão daquelas pessoas envolvidas na administração das indústrias e na gerência dos negócios, do estrato mais alto da burocracia estatal (incluindo os militares) e das principais figuras do partido vitorioso da burocracia"173. Na verdade, Pollock acreditava ser mais difícil reconstruir a forma democrática do que a totalitária, considerando as poucas experiências da primeira e a insurgência da Alemanha Nacional Socialista.

Embora os meios intervencionistas utilizados para a realização dos programas do Estado social apontem para uma espécie de "sociedade totalmente administrada", o diagnóstico de Habermas (e, neste caso, também o de Claus Offe) sobre o capitalismo tardio diferiria em muitos pontos daquele formulado por autores da teoria crítica tais como Theodor Adorno e Max Horkheimer, os quais teriam sido fortemente influenciados pela interpretação que Pollock havia fornecido sobre a forma totalitária adotada pelo capitalismo de Estado ${ }^{174}$. $\mathrm{Na}$ verdade, Habermas endossa em grande medida o argumento de Adorno de acordo com o

\footnotetext{
${ }^{171}$ Habermas, J. "Die Krise des Wohlfahrtsstaates und die Erschöpfung utopischer Energien”, op. cit., p. 151152.

${ }^{172}$ Pollock, F. "State capitalism: Its possibilities and limitations", op. cit., p. 202.

${ }^{173}$ Idem, p. 201.

${ }^{174}$ Cf. de Adorno, T./Horkheimer, M. Dialektik der Aufklärung. In: Adorno, T. W. Gesammelte Schriften 3. Frankfurt/M: Suhrkamp, 1997. Cf. também Adorno, T. „Spätkapitalismus oder Industriegesellschaft?“ In: Adorno, T. W. Gesammelte Schriften 8. Frankfurt/M: Suhrkamp, 1997. Marcos Nobre faz uma discussão do diagnóstico do capitalismo tardio proposto por Adorno, confrontando-o com Habermas. cf. Nobre, M. A Dialética Negativa de Theodor W. Adorno: A ontologia do estado falso, op. cit., capítulo I. Para uma comparação entre Adorno, Habermas e também Offe, ver ainda Keane, J. Public life and late capitalism: Toward a socialist theory of democracy., op. cit., principalmente capítulos 3 e 4.
} 
qual formas de vida burocratizadas e administradas continuam sendo um princípio organizador das sociedades de capitalismo tardio. Porém, esse princípio global de racionalização administrativa, na perspectiva de Habermas, envolveria necessariamente contradições e crises, uma vez que o Estado social seria incapaz de realizar estruturalmente as condições institucionais que assegurassem a legitimação por meio da dominação burocrática. Procurando ilustrar um ponto significativo nas divergências entre Adorno e Habermas, Marcos Nobre lembra que "estas diferenças entre os dois autores revela, mais uma vez, as diferentes posições que assumem frente aos escritos de Pollock. Enquanto Habermas parte da concretização do 'capitalismo de estado na sua forma democrática', Adorno vê no Welfare State um elemento perturbador do diagnóstico - consolidado na década de quarenta - de que se seguia em direção à sociedade totalmente administrada (i. e., uma variante do 'capitalismo de estado em sua forma autoritária')" ${ }^{175}$. Contrário à posição não somente de Adorno, mas também à teoria de Herbert Marcuse sobre a sociedade tecnológica e pós-industrial ${ }^{176}$, Habermas constataria que o capitalismo tardio não poderia homogeneizar e unificar a vida social e política em direção a um totalitarismo racionalizado ${ }^{177}$.

Contudo, não seria somente a experiência de um Estado social mais ou menos bem sucedido que determinaria em seu conjunto a distinção entre uma forma totalitária e outra democrática, mesmo porque os limites e efeitos colaterais do programa reformista viriam à tona paradoxalmente como o preço a ser pago pelas suas próprias conquistas. Um dos argumentos que separariam a formulação de Habermas daquela de Adorno e Horkheimer consistiria também no fato de que, para o primeiro, o próprio diagnóstico das contradições e crises do capitalismo tardio se encontraria apoiado em uma estruturação altamente diferenciada das sociedades complexas na qual a organização da sociedade sobre si mesma mediante a autodeterminação política só poderia se realizar paralelamente ao lado de um sistema econômico regulado pelo mercado e de um sistema administrativo regulado pelo poder. Essa dimensão descritiva da integração social nos forçaria a reconhecer os "ganhos de diferenciação de uma economia capitalista, sem ocultar nem aceitar como fatalidade natural aqueles custos sociais, naturais e ecológicos gerados por uma forma de produção econômica determinada" ${ }^{" 178}$. E isso se aplicaria, certamente, à função integradora do Estado moderno. Contudo, também de sua reconstrução da modernidade a partir dos processos de colonização

\footnotetext{
${ }^{175}$ Nobre, M. A Dialética Negativa de Theodor W. Adorno: A ontologia do estado falso, op. cit., p. 47, em nota.

${ }^{176} \mathrm{Cf}$. Marcuse, H. One-dimensional man: Studies in the ideology of advanced industrial society. London: Routledge, 1991.

${ }^{177}$ Cf. Habermas, J. "Technik und Wissenschaft als 'Ideologie”. In: Habermas, J. Technik und Wissenschaft als "Ideologie", op. cit., p. 54.

${ }^{178}$ Habermas, J. "Ein Gespräch über Fragen der politischen Theorie”, op. cit., p. 145.
} 
sistêmica é preciso admitir e pressupor uma dimensão simbólica de integração social. Como vimos no primeiro capítulo, Habermas diferencia dos meios de regulação do valor de troca e do poder administrativo um código especial, que consistiria na linguagem comum, no meio de integração específico de nossa práxis cotidiana, sobre a qual se desenvolvem as ações comunicativas. A comunicação sobre orientações axiológicas, fins, normas e fatos formam assim também uma fonte fundamental de integração social ${ }^{179}$.

Com isso, não se trata de retomar "a utopia de uma sociedade do trabalho, ou seja, retomar a idéia de uma auto-organização dos trabalhadores" ${ }^{180}$. Nem, em sentido oposto, anular qualquer outra forma de resistência diante de uma suposta onipresença e onipotência da racionalidade instrumental do Estado capitalista. Os círculos do dinheiro e do poder têm de ser controlados e ao mesmo tempo separados dos âmbitos de ação reservados às esferas públicas autônomas. "Sociedades complexas", diz Habermas, "não podem se reproduzir caso não deixem intactas a lógica de autoregulação de uma economia regulada pelo mercado"181. Pois sociedades modernas se encontram diferenciadas não apenas com base em uma autoorganização espontânea e simbolicamente mediada, mas também segundo um sistema econômico regulado pelo dinheiro e pelo sistema administrativo. Além disso, suas funções, embora diferenciadas, se relacionam reciprocamente, sem, contudo, resultar em uma subordinação de uma sobre a outra ou em uma determinação de uma base sobre sua superestrutura.

Em contrapartida, só poderíamos identificar a "caixa de ressonância" da crise do Estado social no modo como os sistemas do dinheiro e do poder se articulam com o compromisso entre Estado e sociedade, compromisso que "constitui o fundamento do qual qualquer política tem de partir em nossos domínios" $" 182$. As constantes intervenções estatais romperiam com esse compromisso em função de sua autoridade planificadora, tornando mais claro que "as consequiências secundárias da juridificação e da burocratização tiraram a inocência do meio aparentemente neutro do poder administrativo, com o qual a sociedade pretendia atuar sobre si mesma" ${ }^{183}$. E isso atingiria o núcleo do programa reformista, cuja política social na esfera de uma democracia de massas assumia a forma de um processo de legitimação regulado administrativamente e dependente da intervenção estatal. Os limites dessa transposição júridico-administrativa do programa político reformista não seriam

\footnotetext{
${ }^{179}$ Cf. Peters, B. Die Integration moderner Gesellschaften. Frankfurt/M: Suhrkamp, 1993, p. 198-214.

${ }^{180}$ Habermas, J. "Interview mit Hans Peter Krüger", op. cit., p 94.

${ }^{181}$ Habermas, J. "Die nachholende Revolution und linker Revisionsbedarf: Was heißt Sozialismus heute?", op. cit., p. 197.

${ }^{182}$ Ibidem.

${ }^{183}$ Idem, p. 199.
} 
sentidos somente como limitação sistêmica de integração social, mas como reificação das relações sociais, como patologia que precisaria ser socialmente controlada não pelo medium poder, mas controlada a partir de baixo, de onde "agora também o Estado intervencionista tem de ser "socialmente controlado"” 184 . Por essa razão, a ampliação de espaços democráticos requer, "sem dúvida", tornar o Estado social mais reflexivo.

Habermas insiste na necessidade de se conceitualizar uma outra relação entre esferas públicas autônomas e auto-organizadas, por um lado, e os domínios de ação controlados pelo dinheiro e pelo poder, do outro lado. É isso o que ele entenderia por uma nova divisão dos poderes na dimensão da integração social. Os processos de reificação sistemicamente induzidos sempre fizeram parte da modernização capitalista. Mas, ao mesmo tempo, foram nos momentos em que a sociedade foi mais impelida a abdicar da interação social reproduzida com base em sua própria vontade que seus sinais de luta e resistência ofereceram as maiores probabilidades de êxito. Como ele mesmo chama atenção no Prefácio de 1990 à oitava edição de Mudança estrutural da esfera pública, os acontecimentos e transformações ocorridos no leste europeu na década de oitenta corroborariam sua recusa de uma perspectiva atrelada ao diagnóstico da "sociedade totalmente administrada", e confirmariam sua concepção complexa de sociedade como mundo da vida e sistema: "A bancarrota do socialismo de Estado confirma isso. O alvo de uma democracia radical é caracterizado antes por uma transposição de forças no interior de uma 'divisão de poderes' que deve ser mantida por princípio" ${ }^{\text {"185 }}$. Embora um forte antiestatismo anime a maior parte desses movimentos de resistência, a política socialista do último século teve de lidar abertamente com o papel cada vez mais presente do Estado na vida social. O colapso das economias planificadas do socialismo realmente existente destruiu toda ligeira esperança de uma democratização daquelas sociedades que ainda deixavam intacta a versão de um projeto político centrado no Estado. Além disso, as manifestações de revolta que engendraram a bancarrota desses regimes sugeriam um novo modelo de política, para o qual a esquerda não poderia fechar os olhos: a crise do capitalismo era abertamente uma crise de legitimação. Tal bancarrota estimulou, sobretudo, uma reconsideração do poder da esfera pública (composto por manifestações coletivas de revolta e organizações da sociedade civil) para resistir politicamente ao Estado, de modo que fosse possível iniciar uma transformação democrática do poder administrativo ${ }^{186}$.

\footnotetext{
${ }^{184}$ Ibidem.

${ }^{185}$ Habermas, J. Strukturwandel der Öffentlichkeit, op. cit., p. 36.

186 Cf. Webbeler, N. Die Gründung der Solidarnosc - Beginn der Demokratisierungsbewegung in Polen: Hintergründe und Rahmenbedingungen, op. cit., p. 14 e ss. Cf. ainda Arato, A./Cohen, J. Civil society and political theory, op. cit., capítulo 1 .
} 
Também Offe mostrou que uma teoria da crise do capitalismo só pode ser hoje uma teoria do déficit de legitimação ${ }^{187}$, mas sua posição difere da de Habermas principalmente no modo como ambos entenderiam esse projeto de tornar o Estado social mais reflexivo ${ }^{188}$. A reconstrução de uma teoria das crises, como proposta por Offe, estaria limitada às capacidades de regulação e às estratégias de reforma do Estado intervencionista. Sua teoria, além da rica descrição das dimensões estruturais e do poder de distribuição entre os sistemas econômico e político no capitalismo tardio, permite que se articule a própria lógica contraditória que residiria na base das pretensões administrativas do Estado e a proliferação de grupos de interesse em conflito: ele identificaria as exigências impostas sobre as intervenções estatais geradoras da crise administrativa acentuando os limites sistêmicos para absorver e neutralizar os efeitos disfuncionais da reprodução capitalista.

Contudo, a teoria de uma crise sistêmica, no limite, acabaria renunciando às pretensões de compreensão das formas de revolta e de contestação social que não se encontrariam localizadas na articulação sistêmica dos interesses e das reformas políticas. Ou seja, Offe poderia articular criticamente a lógica dos interesses em conflito ao analisar os processos em que colidem os imperativos sistêmicos contraditórios, mas não poderia abordar os potenciais de conflito que surgiriam fora dos limites do sistema, pois identifica somente os conflitos de interesse produzidos pela própria lógica da crise de administração (ou seja, pelas próprias reformas). Como nota Cohen, "a fraqueza específica dessa abordagem consiste na incapacidade de elaborar o significado de um déficit de legitimação para os atores sociais em potencial ou já existentes (...) Não é possível ter acesso à ação social envolvida na contestação das interpretações institucionalizadas de normas e valores de um sistema. A relação entre as pretensões universalistas de um sistema político e as interpretações conflitantes dessas mesmas pretensões por aqueles 'dentro' e fora do sistema permanece desconsiderada. O teórico dos sistemas, embora crítico, está limitado pelo domínio de seu próprio objeto para identificar a trajetória somente daqueles eventos (conflitos de interesse) que a própria lógica da administração das crises ou da reforma estrutural articula" ${ }^{189}$.

\footnotetext{
${ }^{187}$ Cf. Offe, C. "Tauschverhältnis und politische Steuerung. Zur Aktualität des Legitimationsproblems”, op. cit., p. 52.

${ }^{188}$ Para um panorama da discussão de Habermas e Offe, assim como a elaboração de uma crítica própria frente ao Estado social, ver novamente Keane, J. Public life and late capitalism: Toward a socialist theory of democracy, op. cit., capítulos 3 e 4; e Marramao, G. "Política e 'complexidade': o Estado tardo-capitalista como categoria e como problema teórico”. In: História do marxismo XII. Rio de Janeiro, Paz e Terra, 1988. Cf. ainda Kaiser, H- R. Staat und gesellschaftliche Integration. Zur Analyse und Kritik des Staatsbegriffs bei Jürgen Habermas und Claus Offe. Marburg: Arbeiterbewegung und gesellschaftswissenschaft, 1977.

${ }^{189}$ Cohen, J. Class and civil society: The limits of Marxian critical theory, op. cit., p. 201-202.
} 
Offe ofereceria assim apenas uma "teoria dos limites da reforma estrutural"190. Nesse caso, a crise significaria antes de tudo tendências contraditórias impostas reciprocamente entre os sistemas (economia, poder administrativo e democracia) que colocariam em risco a própria reforma estrutural. Em primeiro lugar, o sistema administrativo não poderia determinar suas estratégias apenas por meio do planejamento tecnocrático porque, como vimos, precisaria continuar subsidiando as decisões também dos investimentos privados. Em segundo lugar, o sistema político não poderia se estabelecer com base em um acordo político radicalmente democrático entre os cidadãos, pois o Estado estaria orientado pelas decisões administrativas e estratégias burocráticas para selecionar os interesses particulares que adentrariam a arena pública e congelar a autodeterminação política em razão da reprodução passiva do proveito individual das compensações em termos de bem-estar. E por fim, o sistema econômico, mantendo sua lógica de valorização do capital, comportar-se-ia defensivamente diante dos objetivos políticos de manutenção dos interesses coletivos. A crise política não seria senão o diagnóstico da incapacidade do Estado para compensar os riscos disfuncionais decorrentes da produção privada e poder ainda gerar consenso sem infringir as relações capitalistas, sobrecarregar o sistema administrativo e solapar as bases de legitimação necessárias à própria capacidade funcional do Estado. Por conseguinte, tudo o que uma teoria da crise da administração da crise poderia oferecer seria tentar resolver tais problemas por meio de uma "reforma da reforma"191.

Nos termos do modelo complexo da sociedade em dois níveis proposto por Habermas, para que se possa controlar socialmente o Estado intervencionista, não podemos mais simplesmente nos orientar pela necessidade de controle dos sistemas, "mas por traçados de fronteira entre sistema e mundo da vida" ${ }^{192}$. A crise que deveria ser resolvida não é a das perturbações da reprodução material, pois ela nasceria antes no interior da própria realidade social na medida em que os sistemas desenvolvem funções de regulação social formalmente organizados e que colonizam também os âmbitos de reprodução simbólica que estruturam o mundo da vida. Haveria assim uma colisão entre este último, de um lado, e o sistema econômico e o poder administrativo, de outro, os quais assegurariam a integração social através de media deslinguistificados, ou seja, alheios à lógica de um controle comunicativo pela qual a sociedade pode interagir de forma autônoma. Embora a sociedade também se

\footnotetext{
${ }^{190}$ Idem, p. 199.

${ }^{191}$ Cohen, J. Class and civil society: The limits of Marxian critical theory, op. cit., p. 201. Em escritos posteriores, Offe aponta para saídas mais republicanas. Ver Offe, C. "Civil society and social order: Demarcating and combining Market, State and Community”. In: Offe, C. Herausforderungen der Demokratie. Frankfurt/M: Campus, 2003.

${ }^{192}$ Habermas, J. Der Philosophische Diskurs der Moderne, op. cit., p. 414.
} 
reproduza segundo uma racionalidade funcionalista, o ponto de vista normativo para o diagnóstico da crise não se limita à percepção interna à lógica do sistema (seja em relação ao colapso do capitalismo ou à crise de administração), pois “as percepções de crise relativas ao mundo da vida não se deixam transportar integralmente em problemas de controle relativos aos sistemas" ${ }^{\prime 193}$.

Ao tentar domesticar o capitalismo, os social-democratas se resignariam diante do fato de que a economia de mercado não entraria em colapso nem poderia ser revolucionada e democraticamente controlada apenas com base na auto-organização dos trabalhadores. Contudo, também fracassou a idéia de que a influência do Estado sobre o processo de valorização do capital poderia ocorrer segundo meios intervencionistas neutros do poder administrativo: "se agora não mais apenas o capitalismo, mas o próprio Estado intervencionista precisa ser 'socialmente controlado', complicou-se consideravelmente a tarefa. Pois agora aquela combinação de poder e autolimitação inteligente não pode mais ser confiada à capacidade estatal de planejamento"194. Para Habermas, a aposta na emancipação social por meios administrativos ocorria simplesmente por meio de uma substituição do medium do dinheiro pelo do poder, desconsiderando justamente as reações por parte de uma esfera pública política que luta pelos seus espaços de liberdade reificados. Tornar o Estado social mais reflexivo, ou seja, controlá-lo socialmente, implicaria entender que ao projeto de uma democracia social teríamos de vincular os potenciais de uma cultura política altamente democrática. O reformismo simplesmente adota o caminho do poder administrativo, o qual nem é um meio político passivo e muito menos poderia produzir formas de vida emancipadas, pois estas "têm de poder se formar espontaneamente e transformar a si mesmas"195. Para se manter como fundamentalmente democráticas, as formas de vida espontâneas não se deixam simplesmente organizar administrativamente. Elas passariam de uma formação da opinião que se origina na vida cotidiana, produzindo e reproduzindo uma cultura política democrática, para os processos de formação política da vontade juridicamente institucionalizados, os quais necessariamente teriam de ser mais porosos em face de uma formação da opinião produzida não administrativamente, mas sim comunicativamente.

Na leitura de John Sitton, para superar a dicotomia revolução versus reforma, "Habermas procurou formular um projeto político progressista alternativo diante de tais acontecimentos e que, não obstante, pudesse continuar sendo considerado como uma

\footnotetext{
${ }^{193}$ Idem, p. 422.

${ }^{194}$ Habermas, J. “Die Krise des Wohlfahrstaates und die Erschöpfung utopischer Energien”, op. cit., p. 156.

195 Habermas, J. “Interview mit Hans Peter Krüger”, op. cit., p 94.
} 
abordagem socialista, embora envolto pela complexidade da sociedade contemporânea"196. Por um lado, a idéia de uma autodeterminação política não consistiria, certamente, em afirmar diante do sistema econômico e do poder administrativo a possibilidade de sociedades complexas e pluralistas simplesmente se auto-organizarem de forma espontânea segundo o modelo holista de uma comunidade de produtores associados. Habermas não acredita mais que um sistema economicamente diferenciado possa ser transformado a partir do seu interior, conforme as simples receitas da autogestão pelos trabalhadores. O problema parece ser muito mais o de "como os potenciais de auto-organização podem ser suficientemente desenvolvidos em esferas públicas autônomas, de modo que os processos orientados para a formação da vontade de um mundo da vida orientados por valores de uso possam manter sob seu controle os imperativos sistêmicos da economia e do aparelho do Estado, e tornando ambos os subsistemas controlados pelos media dependentes de imperativos do mundo da vida" 197. Além disso, tornar o Estado social mais reflexivo significa apontar uma dimensão da política para além do paradigma produtivista, pois "o projeto do Estado social orientado não apenas à domesticação da economia capitalista, mas também ao controle do próprio Estado, certamente perde o trabalho como seu ponto de referência central. Ou seja, já não se trata mais de assegurar o emprego por tempo integral que se elevou à norma. Tal projeto jamais poderia se esgotar nessa tentativa de, instituindo a garantia de um salário mínimo, romper com a maldição que paira sobre a história de vida de todos os trabalhadores - também sobre o potencial crescente e cada vez mais marginalizado daqueles que continuam na reserva. Esta tentativa seria revolucionária - mas não revolucionária o bastante caso o mundo da vida não pudesse ser protegido não apenas contra os imperativos desumanos do sistema de empregos, mas também contra os efeitos colaterais contraproducentes de uma proteção administrativa da vida em seu conjunto" ${ }^{, 198}$.

Nesse sentido, é possível tornar o Estado social mais reflexivo e democrático por meio de medidas e reformas orientadoras entre as esferas integradoras do dinheiro, poder e também da solidariedade. "Através do amplo leque de espaços públicos e de instituições democráticas", segundo Habermas, "o poder sócio-integrador da solidariedade deve ser capaz de se afirmar sobre os dois outros poderes, dinheiro e poder administrativo. O que há de 'socialista' nisso é a expectativa de que as estruturas reivindicatórias de reconhecimento recíproco, que conhecemos das relações de vida concretas, se transfiram para as relações sociais mediadas jurídica e administrativamente, através dos pressupostos comunicativos dos

\footnotetext{
${ }^{196}$ Sitton, J. Habermas and contemporary society. New York: Palgrave Macmillan, 2003, p. 92-93.

${ }^{197}$ Habermas, J. "Ein Interview mit der New left Review", op. cit., p. 255.

${ }^{198}$ Habermas, J. "Die Krise des Wohlfahrstaates und die Erschöpfung utopischer Energien”, op. cit., p. 157.
} 
processos amplos de formação democrática da opinião e da vontade" ${ }^{\text {199 }}$. Desse modo, da solidariedade seria preciso extrair também uma formação radicalmente democrática da opinião e da vontade, que poderia exercer sua influência sobre a delimitação e o intercâmbio entre, de um lado, as esferas de vida estruturadas comunicativamente e, de outro, o Estado e a economia. Habermas teria de lidar com o problema de saber como as capacidades de autoorganização podem se desenvolver no interior de esferas públicas autônomas de modo que um processo radicalmente democrático de formação política da vontade pudesse exercer um impacto decisivo sobre os mecanismos de regulação do poder administrativo e dos imperativos do mercado, protegendo o espaço de um mundo da vida orientado por valores de uso. Essa tarefa implicaria alguma forma de controle sobre o aparelho intervencionista do Estado e sobre o sistema econômico. E mesmo quando esferas públicas políticas se revoltam contra a opressão dos sistemas, os traçados de fronteira entre sistema e mundo da vida só poderiam se manter caso fossem acompanhados de um processo de democratização amplo e radical $^{200}$.

Nesse ponto, surgem algumas dificuldades internas à teoria habermasiana da democracia. Partindo do arcabouço teórico consolidado em sua Teoria da ação comunicativa, era possível pensar a democracia radical segundo essa nova divisão de poderes porque, para serem sistemicamente integrados, o Estado e a economia não poderiam ser democraticamente transformados a partir de dentro sem que ocorressem danos à própria lógica dos sistemas. Nesse sentido, as diferentes fontes de integração social formariam um equilíbrio que, traduzido politicamente, permitiria a formação de uma "trincheira" democrática contra a colonização dos imperativos sistêmicos sobre o mundo da vida ${ }^{201}$. Em obras subseqüentes, o controle social sobre o Estado leva a uma rearticulação teórica dessa divisão de poderes e também a uma reavaliação do campo do político seguindo uma dupla perspectiva intrumentalnormativa. "De fato", diz Habermas, "o Estado intervencionista transformou-se de tal modo em um subsistema centrado em si mesmo, regulado pelo poder, e atraiu de tal modo os processos de legitimação para o seu ambiente, que se recomenda modificar a própria idéia normativa de uma auto-organização da sociedade. Eu sugiro introduzir uma distinção no próprio conceito do político, seguindo uma dupla perspectiva instrumental-normativa (...) Podemos fazer uma distinção entre o poder produzido comunicativamente e o poder empregado administrativamente. Assim, na esfera pública política encontram-se e

\footnotetext{
${ }^{199}$ Habermas, J. "Die nachholende Revolution und linker Revisionsbedarf: Was heißt Sozialismus heute?", op. cit., p. 199-200.

${ }^{200}$ Cf. Habermas, J. "Entgegnung", op. cit., p. 393.

${ }^{201}$ Cf. Habermas, J. Theorie das kommunikativen Handels, vol. 2, op. cit., p. 575-583.
} 
entrecruzam-se dois processos contrários: a produção comunicativa do poder legítimo, para a qual H. Arendt esboçou um modelo normativo, e a obtenção da legitimação através do sistema político, no qual o poder administrativo se torna reflexivo"202.

Ainda que essa questão necessite de uma investigação mais precisa, acreditamos, contudo, que a rearticulação habermasiana encontrará sua forma mais elaborada em Facticidade e validade, em que a mediação do direito entre sistema e mundo da vida permite uma nova formulação da dinâmica da circulação de poder em sociedades democráticas ${ }^{203}$. Como ainda teremos a oportunidade de ver, a partir da proposta de Bernhard Peters ${ }^{204}$, na qual os processos de comunicação e de decisão do sistema político constitucional são ordenados no eixo centro-periferia, e que as decisões legitimas têm que ser reguladas por fluxos comunicacionais que partem da periferia e atravessam as comportas do Estado, agudiza-se a importância com que a periferia anula a emancipação social ilegítima do poder social e administrativo que não repousa no poder comunicativo. A questão se dirige às estruturas periféricas da formação da opinião, que, caracterizadas na esfera pública, se separam de imperativos sistêmicos. Mas isso não significa contudo que a vontade política dependa puramente de uma racionalização do mundo da vida. É preciso concretizar o potencial crítico das esferas públicas mantendo as condições livres e espontâneas da comunicação, ou seja, relacionar as categorias do mundo da vida com círculos sociais organizados, com associações que são incorporadas no quadro da sociedade civil (igrejas, associações culturais, meios de comunicação, sociedades de debate, grupos de cidadãos, etc.), não se tratando simplesmente de uma separação entre sociedade civil e Estado, mas de uma estrutura própria das sociedades modernas em que as esferas públicas autônomas perpassam também o interior dos espaços institucionais do Estado ${ }^{205}$.

As distintas elaborações da questão referente à nova divisão de poderes na dimensão da integração social têm importância muito maior do que apenas voltar-se à especificação de fissuras ou continuidades na teoria habermasiana. Trata-se de circunscrever as condições nas

\footnotetext{
${ }^{202}$ Habermas, J. "Volkssouveränität als Verfahren”, op. cit., p. 622.

203 Alguns autores acreditam que mesmo em Facticidade e validade o modelo da circulação de poder entre sistemas, de um lado, e esferas públicas autônomas, de outro, parece não encontrar uma solução final. Segundo um artigo de Willian Scheuerman sobre este problema, uma ambigüidade se mantém na tentativa habermasiana de tornar o Estado social mais reflexivo, pois oscila entre a "radicalidade" de uma esfera pública autônoma capaz de influenciar o poder administrativo, e um modelo "defensivo" de democracia, em que o poder comunicativo exerce, no máximo, um controle atenuado sobre o mercado e os processos administrativos. Cf. Scheuerman, W. "Between radicalism and resignation: Democratic theory in Habermas's Between facts and norms". In: Baynes, K.; Schomberg, R. von. (ed.) Discourse and democracy: Essays on Haberma's Between facts and norms. New York University Press, 2002.

${ }^{204}$ Cf. Peters, B. Die Integration moderner Geselschaften, op. cit., parte II.

${ }^{205}$ Cf. Habermas, Faktizität und Geltung, op. cit., p. 426 e ss.
} 
quais seria possível tornar o Estado social mais reflexivo e ampliar os espaços de autonomia sob as circunstâncias de uma democracia de massas. E essa é uma passagem central para compreender de que modo a utopia de uma sociedade do trabalho daria lugar, como veremos, à luta em torno da integridade e autonomia dos estilos de vida, espaços de autorealização, conquistas de direitos e autodeterminação pública. Em outras palavras, os problemas de legitimidade e o conflito entre Estado e sociedade demarcam cada vez mais os limites do paradigma produtivista, de seus meios burocráticos e intervencionistas no processo de autodeterminação pública, ampliando os espaços para a radicalização democrática e para o sentido emancipador reconstruído sob um novo paradigma, o da comunicação. As esferas públicas autônomas teriam de alcançar uma combinação de poder e autolimitação que poderiam tornar os mecanismos de autoregulação do Estado e da economia suficientemente sensíveis diante dos resultados orientados com vistas a uma formação radicalmente democrática da vontade. Esta formação deve ser conforme ao espírito de uma democracia radical, na qual a esquerda socialista poderia encontrar, por sua vez, "seu lugar e seu papel político",206.

Não se trata, assim, apenas de um reformismo radical, de uma tentativa de "reforma da reforma", preconizada, por exemplo, por aqueles que buscam programas alternativos encaminhados pelo Estado não mais centralizados no sistema de empregos e no salário ${ }^{207}$. A tentativa de reformismo radical exigiu sempre soluções concretas e novamente predeterminadas, ao passo que a democracia radical consistiria antes na intenção de "promover uma nova divisão de poderes orientada por procedimentos: através de esferas públicas e instituições amplamente democráticas capazes de se afirmar diante dos outros dois poderes, dinheiro e poder administrativo" ${ }^{, 208}$. Nesse caso, "Habermas teria de romper mais uma vez com o socialismo tradicional (...), pois a tarefa imposta àqueles que ainda se consideram socialistas consistiria em levar em consideração o 'núcleo das condições necessárias para formas de vida emancipadas, sobre as quais os próprios participantes têm de se entender'. A teoria socialista teria de resgatar o impulso emancipatório sem reduzir o socialismo a um conjunto pré-ordenado de arranjos sociais"209.

Habermas se ligaria, portanto, à tradição do marxismo ocidental não porque confia em uma racionalidade das forças produtivas, apoiada em uma filosofia da história materialista,

\footnotetext{
${ }^{206}$ Habermas, J. "Die nachholende Revolution und linker Revisionsbedarf: Was heißt Sozialismus heute?", op. cit., p. 202.

${ }^{207}$ Cf. Vobruba, G. (org). Strukturwandel der Sozialpolitik. Frankfurt/M: Suhrkamp, 1990.

${ }^{208}$ Habermas, J. "Die nachholende Revolution und linker Revisionsbedarf: Was heißt Sozialismus heute?", op. cit., p. 199.

${ }^{209}$ Sitton, J. Habermas and contemporary society, op. cit, p. 93-94.
} 
mas porque aposta no encadeamento da força produtiva da comunicação, pois "o poder administrativo não pode impor limites a si mesmo, ele tem (...) de ser limitado pelo poder gerado comunicativamente" 210 . A formação da opinião e da vontade, que se realiza nas esferas públicas autônomas por meio da prática comunicativa cotidiana, não ocorre passivamente; quando as formas de vida sentem-se ameaçadas, em casos extremos, elas se manifestam e reagem por meio de movimentos sociais, de revoluções, como as que ocorreram a dois séculos na França, ou revoltas, como as que ocorreram na Polônia há dez anos atrás em nome da Solidarnosćc ${ }^{211}$. Haveria assim uma "razão existente", identificável, insiste Habermas, desde os movimentos de emancipação burgueses que formaram duzentos anos de história na Europa e nos Estados Unidos, para que pudéssemos afirmar que o alvo de uma democracia radical não está circunscrito ao poder administrativo ou ao sistema capitalista, mas é caracterizado antes por essa transposição de forças no interior de uma divisão de poderes que, por princípio, pretende se manter de algum modo. Ao afirmar algo como uma força produtiva da comunicação diante dos imperativos reificantes dos sistemas, Habermas parte da experiência concreta de uma sociedade que pressiona e é pressionada pelo Estado e pelo mercado, mas não prescinde de sua autodeterminação política. Nesse sentido, a importância do que Habermas chama de "encadeamento da força produtiva da comunicação" residiria no seu conteúdo político e radicalmente democrático, ou seja, na "vitalização da esfera pública, pluralização da formação da opinião, ampla participação nos processos de tomada de decisão"212, ou seja, na "libertação de energias políticas paralizadas",213.

Habermas conclui em relação à estratégia reformista tal como o faz no caso da orientação revolucionária: os conteúdos utópicos da sociedade do trabalho - a simbiose entre controle racional da natureza e mobilização de energias sociais, a razão instrumental desencadeada no interior das forças produtivas, a razão funcionalista desenvolvida nas capacidades de organização e planejamento estatal - cristalizariam uma imagem de sociedade emancipada em que as condições de vida digna, igualitárias e libertárias do homem, as quais resultam da produtividade das relações de trabalho, são antecipadas em uma totalidade. Porém, "esta totalidade não pode ser antecipada"214, pois "o que se deixa discernir normativamente são condições necessárias, embora gerais, para uma práxis comunicativa

\footnotetext{
${ }^{210}$ Habermas, J. “Interview mit Hans Peter Krüger”, op. cit., p 93.

211 Cf. idem, p. 89-90. Cf. também Webbeler, N. Die Gründung der Solidarnosc - Beginn der Demokratisierungsbewegung in Polen: Hintergründe und Rahmenbedingungen, op. cit.; e Weber, W. Solidarnosc 1980-81 und die Perspektiven der politischen Revolution, op. cit.

${ }^{212}$ Habermas, J. "Interview mit Hans Peter Krüger”, op. cit., p 93.

213 Ibidem.

${ }^{214}$ Habermas, J. “Die Krise des Wohlfahrstaates und die Erschöpfung utopischer Energien”, op. cit., p. 162.
} 
cotidiana e para um processo de formação discursiva da opinião e da vontade, as quais poderiam criar as condições para os próprios participantes realizarem possibilidades concretas de uma vida melhor e menos ameaçada, segundo necessidades e idéias próprias, e por iniciativa própria" ${ }^{215}$. Por um lado, o desenvolvimento do Estado social "acabou num beco

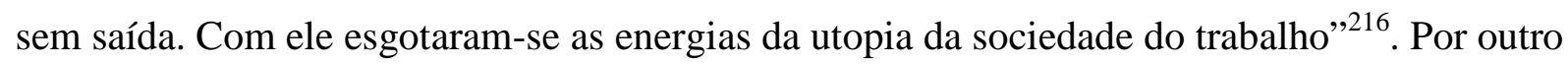
lado, a própria reação da sociedade mostrou que não se trata mais de assegurar simplesmente a saúde do capitalismo, mas é necessário recuperar a dimensão da solidariedade, a qual teria sido abandonada não apenas pelos liberais, mas também pela orientação reformista.

\footnotetext{
${ }^{215}$ Idem, p. 161-162.

${ }^{216}$ Idem, p. 157.
} 
Parte II

Democracia radical:

Para além da dicotomia revolução versus reforma 


\section{Capítulo 3}

\section{Emancipação e democracia radical}

Poderíamos concluir com certo grau de radicalidade a partir dos dois capítulos anteriores que a dicotomia revolução versus reforma como orientação emancipatória predominante resultaria em um bloqueio à libertação de energias políticas paralizadas. Naturalmente, o fim último dos socialistas de forma alguma consistiria em inviabilizar as transformações políticas e sociais. Porém, à luz de "outra grande transformação da autocompreensão das sociedades modernas"1, a qual não resultaria apenas do fim da sociedade do trabalho, mas das novas formas de ação coletiva plurais orientadas e vinculadas às esferas associativas e instituições públicas, as determinações totalizantes respaldadas pela utopia de uma sociedade do trabalho apresentariam sua face mais restrita. Insistimos na tese de que foram os movimentos burgueses de emancipação e de luta por libertação que tornaram possível a própria orientação do socialismo. À primeira vista, essa tese é bastante controversa se considerarmos, sobretudo, o discurso e a atitude dos revolucionários que optaram, diante da experiência política democrática constitucional, por uma revolução radical da organização estabelecida sob o capitalismo - revolução que, como vimos, engoliu a fase democráticoburguesa, "mas no pior sentido. Engoliu o 'burguês', porém mais ainda o 'democrático",2. E não foi uma atitude crítica e negadora apenas do desenho institucional das repúblicas democráticas, mas o sentido normativo mais exigente próprio de constituições modernas foi descartado pela teoria marxista: o sentido normativo da autodeterminação e da autorealização radicais, que perpassaram a tradição democrática desde a Revolução Francesa até os novos movimentos sociais, foram interpretados em termos de autoatividade produtiva e reduzidos à ação baseada no trabalho. A tradição liberal do direito natural e a herança herdada pelo reformismo social-democrata manteve seu vínculo com os princípios constitucionais e com o projeto de universalização dos direitos civis, abdicando, contudo, das fontes radicalmente democráticas no processo de implementação do Estado social

A autocompreensão das sociedades modernas precisaria ser reconstruída de modo que pudéssemos fundamentar seu projeto político adotando o caminho da democracia radical, em que estariam presentes simultaneamente os princípios do Estado democrático de direito e a concepção radical de autonomia, tão almejada pela revolução, como soberania popular. Desde

\footnotetext{
${ }^{1}$ Arato, A./Cohen, J. Civil society and political theory, op. cit., p. 1.

${ }^{2}$ Fausto, R. "Para um balanço crítico das revoluções (e de alguns movimentos de reforma) do século XX (A esquerda onde está?)”, op. cit., p. 232.
} 
a Revolução Francesa, o domínio das leis garantido pelos direitos humanos se vincularia ao princípio da soberania popular, ou seja, nos direitos à comunicação e participação política que assegurariam a autonomia pública dos cidadãos ${ }^{3}$. "Sem saber", diz Habermas, "o próprio Marx se colocou nessa tradição"4. Porém, comenta o autor em outro lugar, em vez de radicalizá-lo, o marxismo "não se apropriou plenamente do conteúdo emancipatório desses acontecimentos históricos" $" 5$.

A rápida reconstrução que Habermas apresentou sobre a Revolução Francesa poderia nos ajudar a determinar o conteúdo emancipatório ocultado pelo paradigma produtivista tendo em vista sua história dos efeitos. Se acompanharmos, ao menos à guisa de introdução, a argumentação proposta, poderemos interpor por outra via o problema da necessidade de revisão da esquerda. A pergunta colocada por Habermas consistiria em saber se a Revolução Francesa não teria esgotado a sua força para a orientação emancipatória no campo da teoria política. Admite-se que, "em relação à sua imponente história dos efeitos, a Revolução Francesa "é dificilmente comparável a algum outro evento histórico",6. Mas além disso, tratase, antes, de saber se, de um ponto de vista normativo, a mudança de mentalidade que se produziu nos anos da Revolução ainda contém aspectos de uma herança que, para nós, pudesse ser necessária - ainda que, em grande medida, irrecuperável. "As idéias da Revolução de 1789”, pergunta Habermas, "permitem que façamos uma leitura que ainda seja informativa para a própria necessidade de orientação?"7

Para uma possível resposta afirmativa à questão sobre a atualidade da Revolução parece ter restado somente um candidato, a saber, aquelas idéias políticas que inspiraram o Estado democrático de direito. Na verdade, tanto a democracia como os direitos humanos formaram o núcleo do Estado constitucional que resultou não apenas da Revolução Francesa, mas também da Revolução Americana ${ }^{8}$. Segundo Habermas, a diferença entre ambas consistiria no fato de que, diferentemente da Revolução Americana, que teria resultado dos acontecimentos que a envolveram, os protagonistas da Revolução Francesa tinham consciência de estarem fazendo uma revolução. Esse elemento ativo da segunda criaria para a orientação contemporânea um sentimento ambíguo, porém decisivo: a consciência revolucionária seria o berço de uma nova mentalidade marcada por uma nova consciência do

\footnotetext{
${ }^{3}$ Cf. Habermas, J. "Über den internen Zusammenhang von Rechtsstaat und Demokratie". In: Habermas, J. Die Einbeziehung des Anderen, op. cit., p. 298 e ss.

${ }^{4}$ Habermas, J. "Naturrecht und Revolution", op. cit., p. 117.

${ }^{5}$ Habermas, J. "Interview mit Hans Peter Krüger", op. cit., p 85.

${ }^{6}$ Habermas, J. "Volkssouveränität als Verfahren”, op. cit., p. 600.

${ }^{7}$ Idem, p. 601.

${ }^{8}$ Cf. Habermas, J. "Naturrecht und Revolution", op. cit., p. 89-102.
} 
tempo, um novo conceito de práxis política e uma nova idéia de legitimação. Consideraríamos fundamentais para nossa própria autocompreensão a consciência histórica que romperia com o tradicionalismo de continuidades naturais; a compreensão da práxis política, que se colocaria sob o símbolo da autodeterminação e da autorealização; e a confiança em um discurso racional em que toda autoridade política deveria poder ser avaliada publicamente como legítima ou ilegítima. Mas teríamos de saber se ainda hoje essa consciência revolucionária que perpassou os anos decorridos entre 1789 e 1794 poderia servir para iluminar as orientações da esquerda e serem frutíferas para o sentidos da emancipação, ou seja, saber se o resgate da democracia radical seria ou não acompanhado pelo empalidecimento do selo propriamente revolucionário. Acompanhando ainda os argumentos de Habermas, nossa consciência acerca da situação revelaria duas coisas: "nós ainda apelamos sempre para a disposição para a ação e para uma orientação prático-moral voltada ao futuro por parte daqueles que querem reconstruir a ordem existente; ao mesmo tempo, porém, diminuiu a confiança em uma transformação revolucionária das circunstâncias"’9. Essa visão retrospectiva parece mostrar que a mentalidade gerada pela Revolução Francesa tanto se tornou duradoura como também trivial: hoje em dia ela não sobreviveria mais na forma de uma consciência revolucionária, tendo perdido tanto sua força explosiva utópica quanto sua expressividade. "Mas com essa mudança de forma", pergunta o autor, "paralisaram-se também suas energias?"

A consciência revolucionária se manifesta na convicção de que os indivíduos emancipados têm de ser autores de seus destinos. Contudo, essa autodeterminação não precisaria ser interpretada em termos de transformação revolucionária, mas poderia ser reconstruída a partir do conceito de autonomia. O “entusiasmo" pela Revolução Francesa a que se referiu Kant, por exemplo, consiste em avaliar positivamente que nas mãos dos sujeitos estaria agora o poder de decidir sobre as regras e o modo de sua convivência, na medida em que eles, enquanto cidadãos, dariam a si mesmos as leis às quais desejam obedecer ${ }^{11}$. A autonomia seria entendida não como produto do trabalho, mas principalmente como produto de uma prática cooperativa centrada na formação política consciente da vontade. Uma política radicalmente democrática seria interpretada, assim, como expressão e confirmação da liberdade que resultaria simultaneamente da subjetividade do indivíduo e da soberania

\footnotetext{
${ }^{9}$ Habermas, J. "Volkssouveränität als Verfahren", op. cit., p. 604.

${ }^{10}$ Idem, p. 608.

${ }^{11}$ Cf. Kant, I. Der Streit der Fakultäten. In: Kant, I. Werke XI. Frankfurt/M: Suhrkamp, 1964, p. 357-360. Ver ainda Terra, R. "É possível defender a legalidade e ter entusiasmo pela revolução? Notas sobre Kant e a Revolução Francesa". In: Terra, R. Passagens: Estudos sobre a filosofia de Kant. Rio de Janeiro: UFRJ, 2003, p. 101-129; e Maus, I. Zur Aufklärung der Demokratietheorie. Frankfurt/M: Suhrkamp, 1992, p. 115-135.
} 
popular. Para Habermas, diferentemente do conceito de trabalho e da atividade produtiva, autodeterminação e autorealização seriam os conceitos-chave para uma prática cujo fim residiria na produção e reprodução de uma vida dignamente humana ${ }^{12}$. No entanto, o conceito holista de prática política, que animou desde republicanos até o modelo de auto-organização coletiva dos trabalhadores, também perderia seu brilho e sua força motivadora, tornando manifestas as contradições inseridas no próprio conceito de soberania popular. O povo, do qual deveria emanar todo o poder organizado em forma de Estado, não formaria um sujeito de nível superior com consciência e vontade, surgindo sempre no plural: enquanto povo ele não é capaz de agir nem de decidir como um todo de forma homogênea. Em sociedades complexas, até os esforços mais sérios de auto-organização política fracassariam perante os obstáculos do sistema econômico e do poder administrativo. É bem verdade que, nos episódios da Revolução, a democracia foi imposta contra o despotismo encarnado no rei, em partes da nobreza e no alto clero. Atualmente, a autoridade política se despersonalizou: a democratização não se confrontaria mais apenas com obstáculos genuinamente políticos, mas com imperativos sistêmicos de um poder administrativo e de uma economia de mercado diferenciados ${ }^{13}$.

Apesar da formação de sociedades altamente complexas, o resgate dos movimentos burgueses por emancipação permitiria sim descobrir como hoje uma república radicalmente democrática teria de ser pensada caso pudéssemos contar com o apoio de uma cultura política capaz de ressonância, ou seja, capaz de se mobilizar diante dos riscos da perda de liberdade. Mas "não uma república", diz Habermas, "que aceitamos como patrimônio a partir do olhar retrospectivo das felizes heranças, mas que desenvolvemos como projeto na consciência de uma revolução que se tornou, ao mesmo tempo, permanente e diária (...) Na consciência revolucionária está inscrita a melancolia - a tristeza pelo fracasso de um projeto todavia irrenunciável. Tanto o fracasso como a necessidade de continuá-lo podem ser explicados pelo fato de que o projeto revolucionário ultrapassa a própria Revolução, subtraindo-se aos seus próprios conceitos. Por isso, eu tento traduzir o conteúdo normativo dessa Revolução sui generis para nossos conceitos, um empreendimento que se impõe a um intelectual de esquerda que vive na Alemanha (...) Os princípios da constituição não lançarão raízes em nossa sensibilidade, a não ser depois que a razão tiver tomado consciência de seus conteúdos orientadores que apontam para o futuro. Somente como projeto histórico o Estado democrático de direito conserva um sentido normativo que aponta para além do aspecto

\footnotetext{
${ }^{12}$ Cf. Faktizität und Geltung, op. cit., p. 124-135.

${ }^{13}$ Cf. Habermas, J. "Volkssouveränität als Verfahren", op. cit., p. 607.
} 
jurídico - conservando assim, de uma só vez, um poder explosivo e formador" "14. Essa posição evidentemente não poderia ser caracterizada literalmente como a mesma que denotou a consciência revolucionária, seja em 1789 ou na sua seguidora de 1917. Mas ela certamente possui atualmente uma força motivacional que, diferentemente da utopia da sociedade do trabalho, ainda não se esgotou, a saber, a "cultura política da era das revoluções democráticas" ${ }^{\prime \prime}$. No limite, seria possível afirmar com Tomberg que Habermas gostaria de ver a "revolução aqui e agora, porém não a entende mais como um ato de violência, mas como um processo de democratização. Formulado de forma paradoxal, ele pode manter a meta vislumbrada pela revolução porque não a entende mais como revolução" ${ }^{\text {"16 }}$.

A autodeterminação foi traduzida para a filosofia da práxis como transformação revolucionária de modo que uma cisão cheia de conseqüências simplesmente separasse política e direito. O resgate da democracia radical em nome da libertação das energias políticas, na forma da argumentação e participação pública, não implicaria renunciar às questões fundamentais sobre a institucionalização da liberdade, mas seu poder explosivo e formador apontaria para além das determinações puramente jurídicas: nos princípios constitucionais estariam contidas também as configurações políticas materiais de cada época, evidenciando-se assim a dimensão reflexiva inerente ao direito moderno que o vincularia necessariamente aos processsos democráticos de legitimação ${ }^{17}$. Se "toda a miséria do assim chamado socialismo realmente existente pode ser remetida basicamente ao descaso desmedido em relação aos princípios do Estado constitucional - como se estes princípios não pertencessem primariamente àquelas forças produtivas, àqueles resultados dos movimentos de libertação burgueses que tornaram o socialismo possível" ${ }^{18}$ - a reconstrução dos potenciais emancipatórios precisaria, portanto, desfazer-se do paradigma produtivista e fazer jus ao seu núcleo normativo, o qual desde Rousseau e Kant se concentrou no conceito de autonomia. $\mathrm{O}$ resgate da democracia radical permite entender, por conseguinte, a gênese do próprio poder comunicativo que, segundo Habermas, se fez valer nos "movimentos burgueses de emancipação - nas lutas pela soberania popular e pelos direitos humanos, e teria se sedimentado nas orientações do Estado democrático de direito e nas instituições da esfera pública burguesa"19.

\footnotetext{
${ }^{14}$ Idem, p. 609-610.

${ }^{15}$ Arato, A./Cohen, J. Civil society and political theory, op. cit., p. 83.

${ }^{16}$ Tomberg, F. Habermas und der Marxismus, op. cit., p. 320.

${ }^{17}$ Cf. Melo, R. S. "Habermas e a estrutura 'reflexiva' do direito", op. cit., p. 67-78.

${ }^{18}$ Habermas, J. "Ein Interview mit der New Left Review", op. cit., p. 254.

${ }^{19}$ Habermas, J. “Interview mit Hans Peter Krüger”, op. cit., p 85.
} 
Já podemos deixar de lado o olhar retrospectivo e nos concentrar finalmente na articulação entre a reconstrução do núcleo do projeto político moderno, a pluralidade de lutas e movimentos sociais na sociedade contemporânea e a formulação de uma teoria da democracia sensível às manifestações da esfera pública. $\mathrm{O}$ vínculo entre Estado democrático de direito e soberania popular permitiria descrever as novas formas de luta política em três dimensões relevantes para a questão da orientação emancipatória e de seus respectivos obstáculos. Em cada uma delas, a relação entre política e direito apontaria para a superação das orientações revolucionárias e reformistas, ou seja, para formas de ação coletiva não baseadas em classes, para os limites dos programas centrados no Estado, para formas de conflito que incluem a esfera pública, a reprodução cultural, as práticas associativas e suas respectivas relações com a esfera jurídica.

A primeira dimensão implicaria a reprodução da esfera de auto-organização ou autoatividade da sociedade paralelamente ao lado do mercado e do Estado em diferentes níveis. Como vimos, o dinheiro e o poder administrativo são empregados para fins não apenas de coordenação funcional, mas de satisfação de necessidades que não podem simplesmente prover. Logo, a participação política dos cidadãos, suas associações e movimentos, orientamse tendo em vista a defesa e a expansão de seus espaços sociais de ação. Tal ação da sociedade sobre si mesma preservaria sua articulação moderna em que as formas de solidariedade coexistiriam com o sistema econômico e com o Estado ${ }^{20}$. Essa divisão de poderes, que teria de ser mantida por princípio, é perpassada pelo desenvolvimento do direito em toda sua extensão, de modo que "os media de regulação compostos pelo dinheiro e pelo poder administrativo sejam ancorados no mundo da vida por meio da institucionalização jurídica dos mercados e das organizações burocráticas" ${ }^{21}$. Cria-se assim não apenas as tendências de juridificação, na medida em que os conflitos são reorganizados na forma da universalização do status de cidadão e submetidos cada vez mais à intervenção da burocracia estatal, mas também garante-se juridicamente novas formas de reprodução social, cultural e política da sociedade civil, redes de associações espontâneas protegidas por direitos fundamentais, assim como formas de comunicação de uma esfera pública autônoma. O direito moderno asseguraria assim uma integração complexa composta de mundos da vida estruturalmente diferenciados - cuja proteção dependeria do grau de institucionalização da autonomia - e sistemas funcionalmente independentes. A colonização dos sistemas geraria uma dinâmica de patologia e resistência em que colidiriam o princípio de soberania popular e

\footnotetext{
${ }^{20}$ Cf. Arato, A./Cohen, J. Civil society and political theory, op. cit., capítulo 9.

${ }^{21}$ Habermas, J. Faktizität und Geltung, op. cit., p. 101.
} 
o princípio funcional de coordenação. Também nessa colisão o princípio democrático da autonomia explicaria por que as interferências do Estado seriam denunciadas não apenas diante de uma esfera pública que deseja restituir sua liberdade política, mas também pelos cidadãos que assumem a definição do status de sua liberdade subjetiva ${ }^{22}$.

Na segunda dimensão, o princípio de autodeterminação permitiria entender de que forma, na própria esfera da solidariedade, poderíamos caracterizar normativamente a realização da liberdade e da igualdade. O pluralismo social e cultural, que se manifesta na individualização de estilos e formas de vida, assim como na composição eticamente heterogênea das sociedades multiculturais atuais, colocaria em questão o modelo holista da soberania popular, exigindo uma reconstrução mais complexa das formas de democracia e dos processos de formação política da opinião e da vontade. Toda tentativa de perseguir um projeto de democracia radical implicaria, desse modo, uma teoria inclusiva e sensível diante da pluralidade de atores, movimentos e tematizações que comporiam a nova tipologia dos conflitos sociais em torno de valores ${ }^{23}$. Nessa dimensão, tornou-se conhecido o debate entre liberais e comunitaristas sobre a justificação normativa dos princípios constitucionais legítimos, articulados pelos princípios formais e universalistas de concepções de justiça ou com base em concepções de bem compartilhadas por comunidades ético-políticas, articulação em que estariam em jogo diferentes concepções de direito e de democracia, de formas de participação política na vida pública e de cidadania, de sociedade civil e de movimentos sociais $^{24}$.

Segue-se assim que, na terceira dimensão, são colocados em questão os limites do modelo representativo de democracia, sobretudo em função da melhor forma de organização do poder político e dos fundamentos da legitimidade desse poder em sociedades complexas e plurais. A solução revolucionária, como vimos, implicava substituir o direito e a política por outras formas de auto-organização social. Os reformistas, por sua vez, adotavam saídas "realistas" que reduziam a importância do fato de que os processos de democratização apontavam para o nexo entre os arranjos institucionais, a participação política e a deliberação pública. $\mathrm{O}$ novo diagnóstico em relação às democracias ocidentais implicaria um modelo de diferenciação e de circulação do poder de acordo com o qual o direito, a política e a esfera

\footnotetext{
${ }^{22}$ Cf. Silva, F. G. "A solidariedade entre público e privado". In: Nobre, M./Terra, R. (org.) Direito e democracia: Um guia de leitura de Habermas, op. cit., p. 91-116.

${ }^{23}$ Cf. Benhabib, S. (ed.) Democracy and difference. Contesting the boundaries of the political. Princenton University Press, 1996.

${ }^{24}$ Cf. Forst, R. Kontexte der Gerechtigkeit. Frankfurt/M: Suhrkamp, 1993; e Werle, D. L. Lutas por reconhecimento e justificação da normatividade (Rawls, Taylor e Habermas). Tese apresentada no Departamento de Filosofia da USP para a obtenção do título de Doutor. São Paulo, 2004.
} 
pública pudessem mediar e compor reflexivamente formas de auto-organização social. As consequiências mais significativas dessa divisão de poderes para a orientação emancipatória se deixam ver no problema da legitimidade do poder político. Pois os mecanismos de representação política - como, por exemplo, o sufrágio universal e as liberdades de expressão, imprensa e de associação - não poderiam prescindir da soberania popular, do envolvimento da cidadania na formação política da opinião e da vontade. A demanda por formas radicais de autonomia permitiria que as práticas e instituições democráticas fossem avaliadas a partir de um uso público da razão, livre e inclusivo, de acordo com a qual a autodeterminação política pudesse resultar da deliberação pública entre os cidadãos ${ }^{25}$.

Portanto, o que se mostra irrenunciável atualmente poderia ser explicado à luz de princípios democráticos uma vez preenchidos com as mobilizações políticas e a pluralidade de enfoques culturais. Porém, seria insuficiente reconstruir os novos movimentos sociais a partir do paradigma revolucionário, não apenas devido aos pressupostos marxistas da teoria de classes centrada no papel eminentemente emancipatório de uma única classe, o proletariado, mas devido à desconsideração do direito e da democracia como lugar legítimo da disputa e dos ganhos políticos e sociais que decorrem e são mobilizados na esfera pública. A afirmação de Habermas, segundo a qual "não se pode ter nem manter um Estado de direito sem democracia radical"26, chama atenção para o vínculo do interesse emancipatório pela restituição da autonomia com a tradição democrática sem que isso signifique cair na antinomia da revolução ou reforma: diferentemente dos revolucionários, não seria possível realizar plenamente a autonomia sem a preocupação pela constituição e a autoestabilização de uma comunidade de livres e iguais; e contrariamente aos reformistas, apenas juntamente com a espontaneidade das diferentes formas de vida o projeto de universalização da cidadania poderia pretender uma legitimidade democrática não instrumentalizada pela transposição administrativa de um programa político.

Com as transformações da sociedade do trabalho, o sentido da emancipação constituído unicamente pela luta de classes é ampliado sensivelmente, estendendo-se igualmente a agenda política da esquerda. Mas as ações coletivas não poderiam voltar a ser descritas com base na imagem de um sujeito de nível superior, que envolvesse sob sua vontade única os sistemas econômico e político assim como a pluralidade de orientações axiológicas e interesses, sejam individuais ou coletivos. A soberania popular seria entendida

\footnotetext{
${ }^{25}$ Cf. Bohman, J. Public deliberation. Cambridge: MIT Press, 2000; Melo, R. S./Werle, D. L. (org.) Democracia deliberativa. São Paulo: Esfera Pública, 2007; e Melo, R. O uso público da razão como procedimento: Pluralismo, discurso e democracia em Habermas. Dissertação apresentada no Departamento de Filosofia da USP para a obtenção do título de Mestre. São Paulo, 2004.

${ }^{26}$ Habermas, J. Faktizität und Geltung, op. cit., p. 13.
} 
como autoatividade apenas ao influenciar o Estado e a economia em uma dinâmica complexa de circulação do poder político, a qual não pode ser desconsiderada. Além disso, também o núcleo normativo do socialismo teria de ser colocado em questão uma vez que a emancipação se desubstancializa na autonomia das diversas formas de vida e a soberania popular se dilui nos processos de formação política da opinião e da vontade destituídos de sujeito (I). As condições de emancipação tocam diretamente nas formas de democracia por meio das quais a autoderminação política não seja cristalizada pelo poder administrativo. $O$ modelo procedimental de política deliberativa não apenas parte de uma avaliação sobre os limites da representação e do engessamento da autonomia política nas democracias de massa, mas também articula de modo inovador a questão fundamental da liberdade e da igualdade no quadro de uma teoria da democracia. A radicalização da autonomia e a autodeterminação do status de cidadania igual serão exemplificados, por fim, a partir das lutas por reconhecimento no Estado democrático de direito e da reconstrução procedimental dos conflitos interpretados novamente em termos de autonomia (II).

\section{I - A soberania popular como procedimento}

1. Os novos movimentos sociais e a ampliação da agenda política da esquerda

Insistimos que a decomposição da sociedade do trabalho consistiu em uma das principais causas da crise do socialismo. Não sem razão, pois a sociedade industrial não determinaria apenas a centralidade do paradigma produtivista de emancipação; ela seria também o ponto de partida para a formação de uma consciência de classe: enquanto grupo social unido por uma consciência comum, a classe seria constituída por meio de luta política em uma situação em que realmente havia trabalhadores da indústria compartilhando condições sociais e econômicas similares ${ }^{27}$. A consciência de classe e a capacidade de autoorganização dos trabalhadores industriais seriam decisivas para que a teoria da emancipação de Marx estivesse ancorada em bases reais ${ }^{28}$. A recomposição orgânica do proletariado faria com que a identidade "classe trabalhadora" perdesse sua centralidade mesmo entre os

\footnotetext{
${ }^{27}$ Cf. Brandt, P. Soziale Bewegung und politische Emanzipation: Studien zur Geschichte der Arbeiterbewegung und des Sozialismus. Bonn: Dietz, 2008, capítulo 1.

${ }^{28}$ Essa unidade consistiria um dos pressupostos mais fundamentais para que o socialismo científico preconizado por Marx e, sobretudo, Engels se diferenciasse do socialismo utópico ou sentimetal, dos modelos do socialismo centrado no Estado (preconizados por Lassale ou Bismarck), assim como dos movimentos anarquistas ou meramente anti-capitalistas. Cf. Draper, H. Karl Marx's theory of revolution IV: Critique of other socialisms. New York: Monthly Review Press, 1990.
} 
trabalhadores ${ }^{29}$. Passava a ser cada vez menos provável que mineradores, enfermeiras, operadores de computador, servidores públicos, professores universitários e jogadores de futebol compartilhassem a mesma "afinidade" e a mesma posição de classe, muito menos a mesma identidade e, sobretudo, os mesmos interesses e necessidades. Essa estratificação social aumentou principalmente com o advento do Estado de bem-estar social: a porcentagem da população economicamente ativa passou a ser maior entre os setores de serviços públicos, associado a todo aparato da administração pública dos caring services, bem como de serviços domésticos privados e de entretenimento, do que entre a manufatura ${ }^{30}$. A recomposição orgânica do proletariado somada à pluralidade de interesses e necessidades que entravam em cena nas novas mobilizações sociais cobrava agora um modelo de política para o qual a teoria da luta de classes não se ajustava mais.

A estratégia reformista, por sua vez, limitou o campo do político à meta de uma administração eficiente pautada no estímulo estatal para o crescimento econômico ao mesmo tempo em que incentivos fiscais e monetários foram utilizados para compensar socialmente disfunções, riscos e incertezas do mecanismo de mercado. Embora tais compensações incluíssem, como vimos, direitos sociais que amenizavam os efeitos negativos do sistema econômico, ou o reconhecimento do papel dos sindicatos no equilíbrio do jogo de forças entre empregador e empregado, a expansão da intervenção estatal e da juridificação deslocou os conflitos entre capital e trabalho para o problema da distribuição justa das chances de vida geradas socialmente. Em nome da igualdade, a intervenção estatal na vida das pessoas colocou em risco a liberdade política e a privacidade, atingindo o sentido dos direitos e liberdades fundamentais ${ }^{31}$. Ao tratar os direitos não como relações políticas e sociais, mas como "coisas" ${ }^{, 32}$, o Estado social privaria a dimensão prática da auto-organização de parceiros do direito. Porém, a crise representou não somente de forma sintomática a contradição entre

\footnotetext{
${ }^{29}$ Existem excelentes trabalhos sobre o processo de transformação orgânica da classe trabalhadora e de sua respectiva reorganização política. Cf. principalmente Groh, D. Emanzipation und Integration: Beiträge zur Sozial- und Politikgeschichte der deutschen Arbeiterbewegung und des 2. Reiches. Konstanz, UVK, 1999, p. 17140; e Gorz, A. Adieux au prolétariat. Galilée, 1980. Sobre a organização política pós 1989, ver Schatz, H. Arbeit als Herrschaft: Die Krise des Leistungsprinzips und seine neoliberale Rekonstruktion. Unrast, 2004. Uma interpretação mais sitemática, envolvendo uma teoria dos movimentos sociais, encontra-se em Raschke, J. Soziale Bewegungen: Ein historisch-systematischer Grundriß. Frankfurt/M: Campus, 1988.

30 “A sociedade 'pós-industrial', ao menos nos países mais avançados, chegou ao seu termo. Uma porção considerável desse setor 'pós-industrial' resultou diretamente do desenvolvimento do Estado de bem-estar. O Estado tornou-se assim o principal ator na estruturação das classes sociais. Um novo e amplo setor público tinha agora uma grande porcentagem na expansão do Estado e partilhava do ethos dos serviços públicos não-fundados no mercado“". Sasoon, D. One hundred years of socialism, op. cit, p. 652-653. Cf. neste mesmo livro as tabelas 22.1 a 22.4. Sobre a relação entre trabalho e o conceito de classe, ver Offe, C. "Tauschverhältnis und politische Steuerung. Zur Aktualität des Legitimationsproblems", op. cit., p. 59 e ss.

${ }^{31}$ Cf. Habermas, J. Theorie des kommunikativen Handels. Band 2, op. cit., p. 522 e ss; e Arato, A./Cohen, J. Civil society and political theory, op. cit., p. 11 e ss.

${ }^{32}$ Young, I. M. Justice and the politics of difference. Princeton, 1990, p. 25.
} 
meios administrativos e fins emancipatórios do programa do Estado social, mas resultou paradoxalmente em uma ampliação do conceito do político que convergiria na restituição da autodeterminação política do cidadão que alienou sua autonomia nos papéis de cliente e consumidor: não seria mais possível determinar o status de cidadania sem que a sociedade fosse concebida como uma esfera autônoma e reflexiva diante do Estado e da economia.

Tal ampliação significou que não seria mais possível interpretar os conflitos sociais como meros epifenômenos do mercado ou em termos de administração estatal, pois diferentes movimentos sociais passavam a ampliar sensivelmente as pautas políticas em discussão não circunscrevendo assim as lutas emancipatórias àquelas ainda presas à sociedade do trabalho, seja na sua forma clássica da luta de classes, seja na sua versão reformista pela distribuição de direitos sociais ${ }^{33}$. Muitos desses movimentos contradizem a imagem daquela esquerda que continua lutando pela supressão completa do capitalismo ou daquela que se limita simplesmente a um comprometimento com sua reforma. Também a lógica competitiva e seletiva da administração política regulada pelo Estado social seria insuficiente para esclarecer a nova tipologia dos conflitos e a dinâmica da ação social coletiva. A negociação política que o Estado social tradicionalmente assumiu estava circunscrita a acordos entre sindicatos, associações de trabalhadores, lobbies das elites econômicas, etc., ou seja, apenas aqueles diversos grupos de interesse em conflito organizados na articulação entre poder estatal e mercado ${ }^{34}$. Essa via reformista foi deslocada agora do aparelho estatal para a sociedade civil, pois o processo de democratização do Estado estava pautado pelo sentimento cético diante das políticas implementadas de cima para baixo. E quanto mais plural os conflitos, mais se tornava evidente para a consciência teórica e para a orientação prática dos atores a necessidade de criticar o centralismo estatal e de superar a dicotomia revolução versus reforma como uma alternativa se não falsa, certamente insuficiente ${ }^{35}$. Pois o locus da democratização perderia suas determinações estritamente econômicas ou burocráticas ao se concentrar na dimensão simbólica em que se reproduzem as diversas formas de vida.

Nossas análises do primeiro capítulo sobre as críticas à teoria das classes já pressupunham transformações políticas e sociais que nos orientavam a adotar uma nova

\footnotetext{
${ }^{33}$ Cf. Melucci, A. "The symbolic challenge of contemporary movements". In Social Research, 52, 4, 1985. Há ainda Touraine, A. "Novos movimentos sociais?". In: Touraine, A. Como sair do liberalismo? Tradução de Maria Leonor Loureiro. Edusc, 1999, e também dele O pós-socialismo. Tradução de Sonia Gldfeder e Ramon Américo Vasques. São Paulo, Brasiliense, 2004., principalmente o cap. 6.

${ }^{34}$ Cf. Offe. C./Wiesenthal, H. "Duas lógicas de ação coletiva: anotações teóricas sobre classe social e forma organizacional”. In: Offe, C. Problemas estruturais do Estado capitalista, op. cit., p. 56-118; e Brandt, P. Soziale Bewegung und politische Emanzipation: Studien zur Geschichte der Arbeiterbewegung und des Sozialismus, op. cit., capítulo 3.

${ }^{35}$ Cf. Cohen, J/Arato, A. Civil society and political theory, op. cit., p. 70.
} 
perspectiva crítica, mas que somente agora poderiam ser apresentadas. A emergência de novos movimentos sociais não caracterizados pela luta de classes significava que as tradicionais explicações marxistas das transformações sociais precisariam ser revistas criticamente. Vimos que, apesar do potencial crítico para denunciar formas de dominação e desigualdade, o conceito de classe não poderia mais ser o referencial exclusivo para uma visão alternativa de sociedade ou para a interpretação das dinâmicas de contestação e transformação do presente. O pressuposto marxista de que as instituições de uma sociedade civil moderna e as relações de classe próprias do modo capitalista de produção são uma e a mesma coisa "encobre os principais aspectos da sociedade que têm de ser questionados e impede toda a compreensão do que é novo nos novos movimentos sociais" ${ }^{\text {"36 }}$. Em vez dos conflitos tradicionalmente considerados pelos socialistas - os quais se concentravam em torno da propriedade, da redistribuição, do salário ou do emprego, etc - , os novos conflitos sociais abrangeriam diferentes causas e objetivos, mobilizações e formas de ação política, mediações e transformações sociais, etc ${ }^{37}$. Estamos nos referindo aqui, primeiramente, às formas de protesto conhecidas como as new politics e os novos movimentos sociais. A emergência desses movimentos coincidiria com a transformação da classe trabalhadora e seriam os principais responsáveis pela inovação necessária no espectro de idéias determinantes das políticas da esquerda a partir de então. Eles seriam os principais atores na transição para uma sociedade pós-industrial, bem como seu sintoma quase imediato.

Para compreendermos as novas contestações sociais e ações políticas seria preciso abandonar a tipologia dos conflitos baseada na oposição de classe e nos orientarmos agora pela transformação pluralista de esferas públicas autônomas e da sociedade civil. No final dos anos de 1960, uma nova e longa transformação política e social entrou em marcha. Os movimentos dos civil rights e dos pacifistas nos Estados Unidos, a revolta de 1968 na França, os protestos estudantis na Alemanha, Inglaterra e mesmo México, as coalizões entre estudantes e trabalhadores na Itália, a mobilização da sociedade civil nos processos de democratização em lugares diversos, como Madrid, Roma e em Praga ainda comunista, bem como em países da América do Sul, etc., seriam apenas alguns dos exemplos de uma ampliação sensível no quadro das políticas progressistas em curso que resultariam na revitalização do discurso da esfera pública e da sociedade civil nos anos $90^{38}$. Desde então, as

\footnotetext{
${ }^{36}$ Cohen, J. Class and civil society: The limits of Marxian critical theory, op. cit., p. xiii.

${ }^{37}$ Cf. Raschke, J. Soziale Bewegungen: Ein historisch-systematischer Grundri $\beta$, op. cit., entre outros, capítulo 6.

${ }^{38}$ Cf. Diani, M./Della Porta, D. Social movements. Oxford: Blackwell, 2006, introdução; e Arato, A./Cohen, J. Civil society and political theory, op. cit., introdução, capítulos 1 e 10; Habermas, J. Strukturwandel der Öffentlichkeit, op. cit., principalmente o novo prefácio de 1990; e Lavalle, A. G. "Sem pena nem glória: O debate da sociedade civil nos anos 1990". In: Novos Estudos CEBRAP, 66, 2003, p. 91-110.
} 
demandas e tematizações, cada vez mais diversas e plurais, seriam compostas principalmente pelo feminismo, com as políticas de gênero, pelas campanhas antinucleares ou movimentos pela paz, movimentos gays e outras amplas políticas em torno da sexualidade, políticas comunitárias localizadas, como os movimentos indígenas, movimentos nacionalistas ou regionais, lutas por reconhecimento, que abrangem sobretudo políticas antiracistas que respondem a problemas de imigração ou lutam pela afirmação de minorias étnicas e culturais, etc. A gama de questões envolvidas nessas novas políticas torna difícil interpretar as relações sociais em termos da posição na estrutura do trabalho ou da relação com os meios de produção, pois elas se distinguiriam dos conflitos precedentes na medida em que "não estariam mais centralizadas nas questões envolvendo produção e distribuição (e, portanto, não seriam 'produtivistas'), enfatizariam também o envolvimento do indivíduo com a vida política ('política na primeira pessoa'), e não poderiam mais ser caracterizadas segundo a teoria das classes, pois estariam sendo amplamente representadas por jovens, também por membros da classe média, pessoas com boa formação educacional, etc. (...) Os conflitos também acentuam questões da vida que não poderiam ser remediadas pelas compensações do Estado social"39.

Essa ampliação dos conflitos não significaria que o capitalismo contemporâneo perderia sua importância para a determinação do processo de reprodução material da sociedade. Pelo contrário. A economia continuaria sendo um dos fatores cruciais geradores de conflito. Porém, veremos que os conflitos se ampliariam porque os problemas se manifestam em outras áreas da vida social. Continuamos explicando as patologias da perda de sentido, da produção de condições de anomia e também psicopatologias com referência a mecanismos impostos pelos imperativos de autovalorização do capital e da ampliação da intervenção, embora nos debrucemos sobre tais questões sempre em termos da predominância sistemicamente induzida da economia e da burocracia, ou seja, de "todas as formas cognitivoinstrumentais de racionalidade presentes nas práticas comunicativas cotidianas que são parciais e "alienadas""40. Em todo caso, o pontencial emancipatório se concentraria nos espaços de solidariedade e na possibilidade de mediação reflexiva, ou seja, de uma divisão de poderes entre mundo da vida e sistemas - divisão que não poderia se manter sem mobilização política e luta pela preservação da autonomia. Por essa razão, a predominância sistêmica e sua relação com os novos movimentos sociais seriam particularmente complexas. Nos dois capítulos anteriores insistimos que o desenvolvimento das forças produtivas bem como os mecanismos de intervenção estatal consistiam meios essenciais de realização da emancipação,

\footnotetext{
${ }^{39}$ Sitton, J. Habermas and contemporary society, op. cit., p. 85-86.

${ }^{40}$ Habermas, J. "Entgegnung", op. cit., p. 342.
} 
para revolucionários e reformistas respectivamente. Nossa atitude diante da técnica, da ciência e do planejamento como instrumentos promissores para o processo revolucionário ou para a realização do socialismo democrático não seria tão animadora. Sobretudo porque a expansão sistêmica causaria, segundo os diagnósticos apresentados, mais reificação. Logo, a atenção se voltaria antes para os âmbitos de ação social não organizados formalmente e seus respectivos processos de institucionalização em um duplo sentido: para a possibilidade de transferir para as relações sociais organizadas pelo direito e pelo poder administrativo o poder social da solidariedade e suas estruturas reivindicatórias de reconhecimento, bem como assegurar as condições democráticas para a autodeterminação e autorealização das diferentes formas de vida. Essa posição distinguiria grande parte dos autores para os quais os novos movimentos sociais seriam um ponto chave para a formulação de uma teoria social crítica.

Um autor como Herbert Marcuse, que partiu do diagnóstico da neutralização da contradição entre forças produtivas e relações de produção, do aumento de controle estatal denunciado por Pollock e da mudança na composição do proletariado, percebeu nos novos movimentos sociais uma das principais forças emancipatórias nas sociedades contemporâneas. Primeiramente porque eles seriam "forças que estão na periferia do sistema e, assim, são mais dificilmente integráveis" "41. Essa imagem da dinâmica social estabelecida em termos de centro e periferia teria como pano de fundo não a mediação, mas a separação entre sociedade e Estado, ressaltando assim o que diferenciaria a avaliação de Marcuse daquela de outros autores, entre os quais Alain Touraine, Jean Cohen, Bernhard Peters e John Keane $^{42}$. Na verdade, os novos movimentos sociais seriam para Marcuse os substitutos do proletariado para adotar o papel de sujeito revolucionário. As críticas à sociedade unidimensional seriam uma resposta aos limites da teoria de classes colocada em questão sob condições de capitalismo tardio, mas seriam compensadas pelo esforço em derivar as novas necessidades radicais não mais de fatores econômicos, mas sim psicológicos e antropológicos que comporiam as manifestações sociais, políticas e culturais ${ }^{43}$. A novidade de Marcuse em notar os potenciais positivos dos estratos sociais não baseados em classe para a nova satisfação radical de necessidades acabaria "viciada pela retenção da noção de um sujeito revolucionário unificado" "44 e pela desconsideração das instituições presentes para o processo

\footnotetext{
${ }^{41}$ Terra, R. "Herbert Marcuse. Os limites do paradigma da revolução: ciência, técnica e movimentos sociais". In: Nobre, M. (org). Curso livre de teoria crítica, op. cit., p. 150.

${ }^{42}$ Cf. Keane, J. Democracy and civil society. London: Verso, 1988. Os outros autores citados serão tratados adiante.

${ }^{43}$ Cf. Marcuse, H. Versuch über die Befreiung, op. cit., p. 237-317.

${ }^{44}$ Cohen, J. Class and civil society: The limits of marxian critical theory, op. cit., p. 5.
} 
emancipatório $^{45}$. Portanto, Marcuse estaria atento aos novos movimentos sociais de seu tempo, "mas sua análise termina por colocá-los, de uma forma ou de outra, no paradigma da revolução, o que tem algumas consequiências perversas. Marcuse não desenvolve uma teoria da democracia, não leva devidamente em conta as conquistas jurídicas seguidas pelos movimentos sociais e se recusa a ver os aspectos problemáticos de certas tendências violentas, intolerantes e repressivas" 46 .

De certa forma, problema semelhante aparece na formulação de Gramsci sobre a sociedade civil, a qual poderia ser descrita como uma sociedade civil socialista no registro do paradigma revolucionário. Mas também Gramsci deu um passo adiante em relação ao marxismo ortodoxo, a ponto de permitir que seus escritos orientassem um novo modelo de socialismo e uma concepção de democracia radical bem diferente daqueles preconizados pelos comunistas, tal como defendeu Carlos Nelson Coutinho ${ }^{47}$. Isso foi possível porque o próprio Gramsci havia reconhecido novas formas de pluralidade e de associações específicas na dimensão da sociedade civil moderna, formada pelo "conjunto das organizações responsáveis pela elaboração e/ou difusão das ideologias, compreendendo o sistema escolar, as igrejas, os partidos políticos, os sindicatos, as organizações profissionais, a organização material da cultura (revistas, jornais, editoras, meios de comunicação de massa), etc." ${ }^{48}$. Nesse sentido, Gransci colocaria em questão a redução economicista da sociedade civil nas obras de Marx, permitindo diferenciá-la da economia e do Estado em razão da formação de consensos culturais e de hegemonia social independentes do sistema econômico e do poder administrativo, cumprindo também funções de reprodução social ${ }^{49}$.

Contudo, dois problemas surgiriam da concepção de Gramsci para podermos entender a partir de sua teoria as novas formas de luta política nas sociedades contemporâneas. Em primeiro lugar, o acento nas formas associativas autônomas e nas instituições culturais para reproduzir a hegemonia da sociedade civil não consistiria simplesmente na perspectiva normativa a partir da qual fosse possível resistir aos imperativos da economia e do poder político. Gramsci nunca negou que essas mesmas condições de auto-organização pudessem levar à revolução, não se limitando a um espaço de autodeterminação que se reproduziria ao lado do Estado e da economia. De onde decorre o segundo problema, o qual emergiria de sua teoria "ampliada" do Estado. Como notou Cohen e Arato, "não é exagero afirmar que a

\footnotetext{
${ }^{45}$ Cf. Idem, p. 6.

${ }^{46}$ Terra, R. "Herbert Marcuse. Os limites do paradigma da revolução: ciência, técnica e movimentos sociais", op. cit., p. 155.

${ }^{47}$ Cf. Coutinho, C. N. Gramsci:Um estudo sobre seu pensamento político, op. cit., p. 255-278.

${ }^{48}$ Idem, p. 127.

${ }^{49}$ Cf. Gramsci. Quaderni del carcere. Vol. 1. Turim: Einaudi, 1975, p. 56-57 e 481.
} 
reformulação dada por Gramsci da idéia de uma via em direção ao socialismo consiste na construção de um novo tipo de sociedade civil autoregulada que tomaria gradualmente todo o controle do Estado sobre a vida social, descartando o Estado e também toda a sociedade política" ${ }^{, 50}$. Essa autolimitação ou diferenciação entre sociedade civil, Estado e economia foi criticada por Carlos Nelson Coutinho. O autor acredita que o modelo de uma democracia radical em Gramsci seria "mais radical" do que aquele fornecido, por exemplo, por Habermas (ou outros autores que mantêm tal diferenciação), pois no caso do autor italiano a "sociedade auto regulada" seria concebida como "a construção progressiva (...) de uma ordem social global fundada no consenso, no autogoverno, na qual a esfera pública intersubjetiva (a 'sociedade civil') subordina e absorve em si o 'poder' e o dinheiro",51. Essa imagem de uma sociedade plenamente autoregulada certamente poderia ser mais radical do que o modelo de uma circulação do poder que pretende conservar a autonomia política. Contudo, ela permaneceria presa ao sentido de emancipação como totalidade, colocando em contradição o próprio pluralismo que o conceito de sociedade civil manteria dentro de si e sua diferenciação diante da reprodução funcional dos sistemas para a integração social de sociedades modernas $^{52}$.

Uma outra importante contribuição teórica sobre os novos movimentos sociais foi apresentada mais atualmente por Alain Touraine, o qual, diferentemente de Marcuse e Gramsci, recusou a explicação dos processos políticos como reflexo de um sujeito total ainda preso ao paradigma da revolução assim como pretendeu dar uma outra descrição da relação entre centro e periferia na dinâmica dos conflitos sociais. O próprio pressuposto dessas novas manifestações fracionaria o sujeito revolucionário e o diluiria em um campo de disputa heterogêneo e independente. Touraine entendeu ser preciso estabelecer uma "análise pósmarxista que finalmente atribuísse às relações de classe e movimentos sociais e, portanto, à ação conflituosa para o controle social de um campo cultural, a importância central que essas relações e movimentos não poderiam pretender no pensamento marxista" ${ }^{\natural 3}$. O que seria decisivo, segundo este autor, consistiria na interação orientada ao conflito que se passa em um campo cultural que permaneceria aberto a interpretações opostas. Em outras palavras, a análise das práticas sociais e a natureza de suas reivindicações estariam envolvidas agora com

\footnotetext{
${ }^{50}$ Cohen, J/Arato, A. Civil society and political theory, op. cit., p. 156.

${ }^{51}$ Coutinho, C. N. Gramsci:Um estudo sobre seu pensamento político, op. cit., p. 269.

${ }^{52}$ Carlos Nelson Coutinho também defende que o modelo de Gramsci seria "mais realista" do que o habermasiano (idem, p. 269-270). É preciso lembrar que Habermas se coloca na tradição da teoria crítica em que é fundamental não apenas o interesse emancipatório da teoria, mas também os diagnósticos, de modo que seria preciso ser simultaneamente marxista e realista diante de sociedades altamente complexas. Voltaremos a isso adiante.

${ }^{53}$ Touraine, A. The voice of the eye. Cambridge University Press, 1981, p. 114.
} 
a gênese das normas e dos conflitos sociais centrada em suas interpretações, as quais se encontrariam sempre em disputa. $\mathrm{Na}$ verdade, a interpretação de Touraine aponta principalmente para um "erro" marxista em se definir as classes em termos econômicos. Pois falar aqui de luta de classes ou de movimentos sociais significaria, em ambos os casos segundo o autor, dar atenção a um tipo de contestação consciente sobre a autoprodução e reprodução da sociedade. Tratar-se-ia antes de um controle dos agentes sobre sua própria história e formação renovadas a cada vez de forma consciente em torno das normas, instituições e práticas sociais. Colocada nesses termos, segundo o comentário de Jean Cohen, a própria luta de classes na interpretação de Touraine consistiria em uma contestação consciente, porém historicamente determinada, entre duas classes sociais opostas que estariam em conflito sobre a interpretação de um modelo cultural de sociedade, ou seja, "representam modos alternativos de interpretação das normas e de institucionalização do modelo cultural do presente $^{, 54}$.

Os novos movimentos sociais expandiriam esse modelo cultural específico e forçariam os pressupostos teóricos de cunho marxista a uma redefinição. Segundo os pressupostos da teoria da ação de Touraine, os conflitos sociais não poderiam ter como orientação determinante uma luta contra os sistemas, pois as disputas se estabeleceriam em torno das interpretações conflitantes sobre a constituição dos próprios movimentos e de suas identidades sociais. As contestações se baseariam em suas respectivas experiências de "sofrimento, da recusa dos valores industriais e da procura de uma nova forma de viver" ${ }^{\text {,5 }}$. Mas tais experiências plurais das lutas sociais sugeririam uma falsa unidade para todos esses fenômenos de recusa política, sobretudo aqueles que contestam políticas meramente liberais. Essa falsa unidade social se cristalizou nas clássicas teorias de classe a partir de um determinismo econômico que impossibilitou uma explicação da verdadeira dinâmica dos movimentos sociais, de seu espaço independente no qual interpretações diferenciadas colidem entre si para conquistar a hegemonia das concepções ideológicas e axiológicas dominantes.

Os novos movimentos sociais, por sua vez, não se deixariam determinar segundo ações de estratégia política. Para que pudessem manter sua independência, ou seja, sua autoprodução da identidade, Touraine teve de relegar o locus dos movimentos sociais à periferia do sistema, distinguindo assim "luta social" de "ação política" em sentido estrito. Semelhantemente a como os pensou Marcuse, ao constituírem a si mesmos, o sucesso dos movimentos sociais dependeria de que os conflitos fossem periféricos em relação à

\footnotetext{
${ }^{54}$ Cohen, J. Class and civil society: The limits of marxian critical theory, op. cit., p. 214.

55 Touraine, A. O pós-socialismo, op. cit., p. 121.
} 
reprodução material da sociedade através dos sistemas, embora modificando implícita, e não explicitamente, como pretendeu o autor alemão, a composição da ordem social estabelecida. Desse modo, a autocompreensão da atividade dos participantes dos movimentos não poderia ser configurada como estratégica. Isso decorreria da relação entre o que se entendeu tradicionalmente por movimento social e movimento cultural. "Entre os dois", diz Touraine, "colocam-se lutas, tanto sociais quanto culturais, que combatem a mudança social em nome da identidade cultural" ${ }^{156}$. Ou seja, as próprias lutas seriam determinadas pelo modo como os indivíduos procuram criar novas formas de ação coletiva na sociedade com a finalidade de transformar ou manter sua identidade. A ação coletiva de modo algum poderia ser definida socialmente por algo que não essa autoprodução da identidade, cuja autodeterminação implicaria a escolha dos próprios fins e meios, sem subordinação a partidos ou ideologias: “As formas das quais tínhamos experiência mobilizavam militantes idealistas, recorriam à sua abnegação, incumbiam-nos de participarem de grandes campanhas reivindicatórias. Hoje em dia, rejeita-se essa imagem de militante, mesmo no seio do movimento (...) Os que coordenam os novos movimentos sociais querem viver e organizar-se à imagem da vida social que querem criar (...) São grupos menos instrumentais do que expressivos, cujos participantes se sentem gratificados tanto pela experiência que neles vivenciam quanto pela consciência da missão que executam" ${ }^{\text {57 }}$. Touraine considera ainda mais significativo a distinção entre o comportamento e o tom das reivindicações e ações coletivas dos novos movimentos sociais em relação ao passado. Pois no caso dos movimentos atuais "o tom passa da extrema excitação e da denúncia à explicação que procura muito mais reforçar a convicção do que provocar a mobilização" ${ }^{58}$. Isso porque, como insistimos, o movimento social é ao mesmo tempo cultural e encontra maneiras de contestação sempre atreladas à tematização e simbolização de identificação, tais como vestimentas, posturas corporais, referências ao corpo e à emoção opostas ao mundo frio da estratégia e da tecnocracia: "não há movimento cultural ou social importante que não crie um jeito de falar, de se vestir, de se comportar" ${ }^{\prime 59}$.

Sobretudo os movimentos a partir da década de 80 foram aqueles em que mais se evidenciaria o fato de não concentrarem suas ações em estratégias tais como a defesa das condições de trabalho e salário. "Por seu conteúdo, e não só por seu contexto", diz Touraine, "foram geralmente movimentos formados para a defesa de direitos culturais"60. Não são

\footnotetext{
${ }^{56}$ Idem, p. 128.

${ }^{57}$ Idem, p. 138-9.

${ }^{58}$ Idem, p. 139.

${ }^{59}$ Idem, p. 140.

${ }^{60}$ Touraine, A. "Novos movimentos sociais?", op. cit., p. 69.
} 
portanto apenas movimentos de recusa, mas fazem reivindicações "em nome de um atributo positivo" ${ }^{\text {,61 }}$. Problemas de emprego e salário ainda seriam importantes, mas a dimensão da esfera pública e a mobilização da sociedade civil passaria fundamentalmente pela reivindicação de direitos culturais, pelo gênero de lutas pautadas não pelos movimentos diretamente opostos à lógica do mercado, mas pelas políticas de identidade e diferença. Essa especificidade dos novos movimentos sociais não poderia ser explicada apenas pelos direitos democráticos à liberdade de opinião, de reunião e de organização, mas fundamentalmente pelos direitos à identidade pessoal e cultural, pela possibilidade de definição reflexiva dos contornos da autorealização constantemente construída e transformada.

Os movimentos sociais possibilitariam interpretar os conflitos políticos contemporâneos, portanto, não apenas como reflexo da penetração do Estado e da economia sobre esferas da sociedade, ou seja, como crise gerada pela colonização do mundo da vida pelo sistema. Ao destacar os conflitos em torno das determinações culturais em negociação, a proliferação das contestações sociais sobre questões não-econômicas e não-políticas (no sentido de que não se trata de disputas internas ao Estado, entre partidos, sindicatos, etc.) apontaria para uma crescente reflexividade da construção social da realidade, bem como uma indiscutível expansão do espaço nas quais as normas se encontrariam em disputa. E esse espaço precisaria ser transformado no tempo presente. O movimento operário, caracterizado pela transformação radical da sociedade do trabalho em termos de autoatividade produtiva, lutava em nome da abundância, do progresso e, principalmente, de um futuro desejável e necessário. Touraine entende que a defesa dos direitos culturais e sociais dos indivíduos e minorias seria atualmente uma finalidade positiva desses movimentos. Desse modo, "não é mais em nome da sociedade perfeita que esses movimentos falam, e não é para o futuro que olham: eles combatem pela defesa do direito de todos a uma existência livre e 'humana'. A forma assumida hoje pelo princípio geral sobre o qual repousam todos os movimentos sociais é esta: o direito à igualdade cultural" ${ }^{, 62}$.

A análise de Touraine permitiria ver assim que a concepção marxista de classe não poderia dar conta de uma multiplicidade de formas de contestações por meio das quais a sociedade se reproduziria e se transformaria. E embora mantenha um discurso ligado à identidade e à cultura, Touraine também procura apontar para um outro importante limite da abordagem marxista da ação social. Por não se encontrar separada do conflito social, a orientação cultural também se cristalizaria em instituições: os movimentos sociais não

\footnotetext{
${ }^{61}$ Idem, p. 70.

${ }^{62}$ Idem, p. 73.
} 
objetivariam apenas a defesa e a autonomia da sociedade contra o Estado, mas também a defesa e a democratização das instituições em que se tornariam visíveis questões de discriminação, desigualdade e de dominação. "Entre os movimentos sociais e a democracia", comenta Touraine, "há laços diretos (...) Os que opõem a democracia real à democracia formal, as liberdades proletárias às liberdades burguesas, apenas demonstram que são avessos ou hostis à democracia" ${ }^{\prime 63}$. As formas de democracia a favor das quais os novos movimentos sociais lutam procurariam "reconstruir coletividades locais, defender e desenvolver a autonomia da opinião pública, substituir as comunidades tradicionais dissolvidas por organizações voluntárias" ${ }^{\text {, }}$, etc. Os conflitos contemporâneos não seguiriam o caminho da revolução e das guerras, mas o "dos movimentos sociais, da democracia e das reformas"65. É verdade que o Estado poderia intervir no campo dos movimentos sociais e modificar ou mesmo abolir as condições que tornam suas reivindicações possíveis. Mas Touraine não deixa de frisar a necessidade de se manter uma dupla perspectiva para a compreensão da democratização, formada pela sociedade civil e pelas instituições que a compõem: a autonomia e a democratização das instituições da sociedade civil estariam assim no centro dos conflitos sociais contemporâneos.

Utilizando o conceito de sociedade civil com a finalidade de investigar e criticar o potencial explicativo da teoria marxista de classe, Jean Cohen chega a conclusões semelhantes em relação à tarefa de uma nova teoria crítica da sociedade. A autora investiga detidamente os problemas que decorrem de uma identificação estrita das relações institucionais de dominação (nas quais estariam o Estado, a família, cultura, educação, etc.) com somente as relações de produção. Segundo a autora, "em vez das várias esferas da vida social serem reduzidas a meros epifenômenos das relações econômicas, a noção de práxis revolucionária crítica envolvida na luta contra formas institucionalizadas de dominação e de ideologias legitimadoras deve apontar para a possível emergência de uma pluralidade de movimentos sociais e de grupos cujas necessidades e conflitos visam a uma nova forma de sociedade"

Para Cohen, apesar de apresentar problemas em sua teoria dos movimentos sociais, Touraine preencheria um "déficit sociológico" na distinção habermasiana entre sistema e mundo da vida. A virtude da explicação de Habermas consistiria não somente em determinar a reprodução simbólica específica da sociedade a partir de uma teoria da ação comunicativa, mas também vincular esta à teoria sistêmica para explicar crises de identidade social e

\footnotetext{
${ }^{63}$ Touraine, A. O pós-socialismo, op. cit., p. 161.

${ }^{64}$ Idem, p. 168.

${ }^{65}$ Idem, p. 163.

${ }^{66}$ Cohen, J. Class and civil society: The limits of marxian critical theory, op. cit., p. 81-2.
} 
formação cultural. Entretanto, aos olhos da autora, "a estrutura de Habermas não dá lugar para os movimentos sociais - eles não exercem qualquer papel constitutivo em relação à legitimação, ao funcionamento da esfera pública ou à criação de normas"67. A solução habermasiana manteria uma tensão não tematizada entre sua teoria da ação e sua teoria sistêmica, entre a "norma e a realidade“68. Por outro lado, a explicação sociológica de Touraine apresentaria um "déficit normativo": "Se procedermos da análise puramente imanente da contestação social, como Touraine tem de insistir, o teórico da ação se coloca em face de um dilema. Excluindo qualquer referência ao sistema ou à estrutura, à filosofia prática ou à teoria da evolução, o teórico da ação não encontra meios para identificar a unidade das lutas que subjazem à multiplicidade de contestações de uma sociedade" ${ }^{\natural 9}$. Na verdade, tal unidade dependeria de uma hierarquia que se mantém presente na análise de Touraine, na medida em que as formas de luta são classificadas em relação à possibilidade de um movimento social elevar a sua contestação ao patamar determinante de um dado modelo cultural. Das variadas questões a serem contestadas até a consolidação de um movimento social negociando e reinterpretando um certo modelo cultural vigente, sua análise não poderia ir além da constatação das próprias disputas na consolidação dos "tipos sociais" que chegariam ao topo dessa hierarquia - no seu momento histórico, o proletariado contra a burguesia; atualmente, por exemplo, o movimento das mulheres ou o discurso de minorias étnicas, etc. Ainda que desse conta do movimento característico da ação social e caracterizasse as novas lutas em torno dos direitos culturais, na verdade Touraine estaria ainda limitado em face da pluralidade dos atores sociais e da particularidade dos diferentes processos históricos. Por isso, sua teoria não poderia oferecer uma teoria da ação em que pudéssemos pressupor nos próprios movimentos sociais uma dimensão crescente de autoreflexão. Tais pressupostos não se encontrariam explicitamente apresentados, mas orientariam os processos de comunicação em que se engajam os próprios atores ao articularem suas novas identidades e suas demandas sociais.

Além disso, por fim, Touraine não conseguiria explicar uma dimensão considerada fundamental para os novos movimentos sociais, a saber, que na mediação entre periferia e sistema as lutas mobilizadas pelos atores procurariam assegurar uma influência das instituições democráticas sobre o sistema político e a economia. Sem essa dimensão estratégica, a sociedade civil seria ainda mais vulnerável diante do poder administrativo e do

\footnotetext{
${ }^{67}$ Idem, p. 210.

${ }^{68}$ Ibidem. Vale lembrar que Cohen está lidando nesse livro com textos anteriores a Teoria da ação comunicativa, que é de 1981.

${ }^{69}$ Idem, p. 216.
} 
mercado, restringindo o foco das ações coletivas: "Touraine dá um passo em falso ao excluir a interação estratégica do conceito de movimento social e de sua vaga imagem da sociedade civil. Ele está correto em afirmar que a perspectiva unilateral centrada apenas na estratégia desconsidera as dimensões sociais e normativas das lutas contemporâneas que são centrais para a emergência das novas identidades coletivas. Mas ele está equivocado ao restringir a interação estratégica a um patamar menos importante de conflito porque (...) tanto os movimentos sociais quanto a sociedade civil envolvem a interação estratégica"70. E seria justamente por essa razão que ele não explicaria os mecanismos de mediação entre sociedade civil, Estado e economia.

No livro Sociedade civil e teoria política, Cohen desenvolve juntamente com Andrew Arato uma teoria sistemática sobre a sociedade civil. Os autores procuram delinear um projeto normativo, "pós-marxista", capaz de abranger o núcleo pluralista dos novos movimentos sociais no horizonte de uma teoria crítica. A teoria da sociedade civil parte da experiência de uma revitalização do "discurso da sociedade civil" no leste europeu, na América Latina, bem como nas democracias capitalistas avançadas, envolvendo lutas por direitos e sua expansão, associações e iniciativas civis e a construção de instituições e fóruns públicos de discussão que exerceriam a função de racionalização e crítica do poder político. No interior dessa teoria sistemática, "os movimentos sociais constituem o elemento dinâmico no processo que poderia realizar os potenciais positivos das sociedades civis modernas" "71, potenciais que não poderiam ser explicados pelo primado das contradições estruturais, das classes econômicas e das crises, ou seja, no quadro da teoria marxista ortodoxa. Os autores buscariam na teoria de Habermas, contudo, uma teoria complexa da razão prática que preenchesse as incompletudes da análise de Touraine, capaz de articular a especificidade dos processos políticos manifestados nos movimentos sociais, apontar também os limites dessas próprias manifestações em termos de perdas e ganhos de autodeterminação e autorealização para os próprios concernidos, e descrever as relações entre diferentes tipos de ação que perpassam os conflitos coletivos $^{72}$. Além disso, a abordagem habermasiana se ocuparia da tarefa política dupla que comporia os novos movimentos sociais e que os próprios autores pretendem levar adiante: a influência conquistada pela sociedade civil (suas associações e organizações sociais e políticas) estaria vinculada também à institucionalização de suas conquistas (novas identidades, formas de associação autônomas e igualitárias, instituições democráticas, etc. $)^{73}$.

\footnotetext{
${ }^{70}$ Arato, A./Cohen, J. Civil society and political theory, op. cit., p. 520.

${ }^{71}$ Idem, p. 492.

${ }^{72}$ Cf. idem, p. 520 e ss.

${ }^{73}$ Cf. idem, p. 555 e ss.
} 
A afirmação de Cohen de que Habermas desconsideraria os movimentos sociais na estruturação de sua teoria foi desmentida nesse livro de $1992^{74}$. Na verdade, desde Crise de legitimação no capitalismo tardio, o fato de os movimentos sociais serem interpretados como conflitos surgidos no processo evolutivo de experiências possíveis que institucionalizam novas competências culturais e morais não impossibilitaria encontrar o "componente ativo" que faltaria no quadro de uma teoria da evolução social. Nesse contexto, os novos movimentos sociais se apoiariam no processo de racionalização do mundo da vida que se manifestaria, a partir de tradições culturais modernas - tais como a ciência, a arte pós-aurática e o universalismo moral - , nas experiências complexas de contracultura mais ativas (movimento estudantil, pacifistas, movimento das mulheres, etc) ou mais reativas (hippies, Jesus-people, subcultura das drogas, etc) ${ }^{75}$. Um traço constante, contudo, diria respeito à sua lógica de justificação da interpretação dos valores e das normas sempre a partir de seus potenciais culturais e da evolução moral desenvolvidos em um nível mais abstrato de racionalização cultural. Desde então, na reconstrução da teoria, a emergência da modernidade cultural foi acompanhada de um crescente potencial de autoreflexão e de individualização, possibilitando formas pós-convencionais de articulação da vida cultural, social e política. A tese da modernização do mundo da vida lançaria luz sobre as formas reflexivas de socialização e reprodução cultural incorporadas no cotidiano das pessoas, na formação da opinião e nos processos políticos de justificação pública ${ }^{76}$.

Já vimos anteriormente que Habermas não admite o diagnóstico da sociedade totalmente administrada comum à primeira geração da teoria crítica. Mesmo sob condições de um capitalismo administrado, rejeita-se a concepção segundo a qual os indivíduos se encontrariam totalmente subordinados a uma economia oligopolista e a um Estado autoritário. A partir de 1981, sua tarefa crítica consistiria em diagnosticar o avanço dos imperativos sistêmicos sobre as estruturas comunicativas que se encontram entrincheiradas na esfera pública de um mundo da vida racionalizado ${ }^{77}$. Mas o resultado não se basearia em um conflito aberto e sim em uma espécie de "revolução silenciosa" - o que não significaria a interrupção plena dos conflitos, mas a identificação do potencial de resistência atrelado agora a questões da gramática das formas de vida, ou seja, às questões próprias das new politics: "problemas

\footnotetext{
${ }^{74}$ Cf. idem, p. 524 e ss.

${ }^{75}$ Cf. Habermas, J. Legitimationsprobleme im Spätkapitalismus, op. cit., p. 125 e ss.

${ }^{76} \mathrm{O}$ autor retoma esses argumentos em Habermas, J. Vergangenheit als Zukunft, op. cit., p. 54 e ss.

${ }^{77}$ Cf. Habermas, J. Theorie des kommunikativen Handels. Band 2, op. cit., p. 575.
} 
de qualidade de vida, de direitos iguais, de autorealização individual, de participação e de direitos humanos",78, etc.

É fundamental entender, primeiramente, que, embora os movimentos sociais tivessem sido percebidos como novas possibilidades de participação política sob a crise de legitimação produzida pelo Estado social, a análise de Habermas permitiria considerar sua característica inevitavelmente ambígua, ou seja, suas possibilidades e também seus limites, atribuindo “à maioria das formas desses novos movimentos sociais um potencial de resistência e de recuo",79. Ora, se um dos fundamentos da teoria crítica consiste em apresentar "o existente do ponto de vista das oportunidades de emancipação relativamente à dominação vigente ${ }^{\text {“80, }}$, podemos ver nos novos movimentos sociais uma manifestação positiva desse potencial emancipatório - mas não incondicionalmente, ou seja, caso suas demandas não possam ser traduzidas em termos de autonomia e articuladas com o sistema político, como ainda veremos. A classificação daqueles movimentos que possuem um potencial de resistência é particularmente difícil por serem mais difusos, tais como os movimentos antinucleares, ecológicos e pacifistas, certas minorias, movimentos fundamentalistas, movimentos contra a modernização, etc. Apenas o movimento feminista e o movimento dos civil rights nos EUA distinguem-se, nesse espectro, como contendo potenciais emancipatórios mais claros ${ }^{81}$. Além disso, nesse modelo apresentado em sua Teoria da ação comunicativa, o potencial emancipatório manifestado nos novos movimentos sociais seria constitutivo, na verdade, de um mundo da vida que se encontra, por assim dizer, "em perigo". Mesmo que pudéssemos entendê-lo numa lógica diferente daquela dos sistemas, em grande medida o mundo da vida apenas responderia - ou seja, resistiria - às patologias resultantes da colonização por parte do Estado e do mercado capitalista. Por um lado, as questões e tematizações abrangentes e diversas que se encontram na base das contestações coletivas se limitariam aos conflitos resultantes das patologias sociais; por outro lado, as gramáticas das formas de vida interpretadas e negociadas na esfera do mundo da vida figurariam como um espaço politicamente mais independente no jogo de forças em face dos sistemas.

Ainda assim, os novos movimentos sociais seriam interpretados a partir de sua representação ambígua diante do sistema político. Ao ser perguntado sobre a direção e a durabilidade desses movimentos, Habermas comenta: "Sob as condições de recessão

\footnotetext{
${ }^{78}$ Idem, p. 577.

${ }^{79}$ Tomberg, F. Habermas und der Marxismus, op. cit., p. 330 e ss.

${ }^{80}$ Nobre, M. A teoria crítica. Rio de Janeiro, Jorge Zahar, 2004, p. 10. Cf. ainda Habermas, J. Theorie das kommunikativen Handels, Band 2, op. cit., p. 549-550 e 578.

${ }^{81}$ Cf. Habermas, J. Theorie des kommunikativen Handels. Band 2, op. cit., p. 368 e ss.
} 
persistente e desemprego crescente estes movimentos são de natureza mais defensiva, menos articulados do que eram os estudantes; talvez sejam mais realistas em sua interpretação das situações; sobretudo são recrutados a partir de idéias sociais mais abrangentes (...) A base social mais ampla ainda não basta, contudo, para um poder de veto bem fundamentado em estruturas sociais. No momento essa aliança 'antiprodutivista' está demonstrando ter um certo poder de contágio sócio-psicológico, embora não ocupe qualquer área funcional vital da sociedade industrial. Mesmo que na manifestação destes potenciais de resistência haja subidas e descidas imprevisíveis, considero falso o prognóstico segundo o qual a raiva das pessoas logo irá se esvaecer. A raiva é produzida estruturalmente" ${ }^{\natural 2}$. Por um lado, velhos e jovens, mulheres e desempregados, homossexuais e deficientes, crentes e ateus - todos formam uma "aliança antiprodutivista" cujo vínculo consistiria "na recusa dessa visão produtivista do progresso". Nesse caso, eles também partilhariam de posições comuns a legitimistas do Estado social, representados pela social democracia de direita, e a neoconservadores, ao concordarem que "os domínios de interação do mundo da vida carentes de proteção só podem desempenhar um papel passivo diante do Estado e da economia, verdadeiros motores da modernização social" ${ }^{, 83}$. Para a direita, esses grupos não passariam de excluídos que se encontram à margem do processo de produção, uma minoria desarticulada que não teria poder de decisão. Contudo, eles seriam capazes de avaliar os riscos na aposta de uma domesticação social do capitalismo ou de uma retransferência ao mercado dos problemas da administração. Esses dissidentes da sociedade industrial entenderiam que o mundo da vida já se encontra ameaçado pela mercantilização e pela burocratização. No entanto, apesar de pertencerem a uma corrente democrata radical abandonada pela social democracia, enquanto eles não ultrapassarem a mera dissidência e permanecerem limitados ao que Habermas chama de "fundamentalismo da Grande Recusa", esses movimentos ficariam aquém do próprio programa reformista do Estado social ${ }^{84}$.

Se o potencial emancipatório não pode se fundamentar em uma concepção resignada do mundo da vida que apenas resiste ao sistema, derivada, por sua vez, do diagnóstico do Estado intervencionista, ainda assim a nova estratégia em relação ao mundo da vida não parece encontrar uma solução na insistência de posturas simplesmente mais agressivas contra os media do poder e do dinheiro. Na verdade, essa estratégia adotará uma via política bem particular. "Sua virada”, comenta Tomberg, “(...) consiste em também aceitar o modelo de reforma imanente ao sistema, sem por isso se afastar fundamentalmente de suas intenções

\footnotetext{
${ }^{82}$ Habermas, J. "Ein Interview mit der New left Review”, op. cit., p. 249.

${ }^{83}$ Habermas, J. "Die Krise des Wohlfahrtstattes und die Erschöpfung utopischer Energien”, op. cit., p. 155.

${ }^{84}$ Cf. Idem, p. 156.
} 
radicalmente democráticas“ ${ }^{\text {} 85}$. Concordamos com Tomberg ao indicar que a pretensa solução reformista e ao mesmo tempo radicalmente democrática de Habermas decorre de sua decisão tomada perante um dilema político fundamental que se reflete na solução conceitual (dualista) de sua teoria: "Se não deve ser possível que o sistema capitalista, por falta de crescimento, entre em uma crise em que ele tem de se partir, se com isso a emancipação do mundo da vida pressupõe a existência continuada do sistema capitalista e este só for possível segundo um crescimento constante, então a conclusão necessária seria aquela colonização por meio da qual a emancipação do mundo da vida seria anulada. A conservação de um mundo da vida autônomo e o capitalismo tardio colonizador se contradizem mutuamente e exigem uma decisão, da qual Habermas não se esquiva. Contudo, ele tem de se decidir tanto por um quanto pelo outro. Ele aceitou o caráter definitivo do capitalismo, que entretanto tem de ser concebido somente como capitalismo tardio, como compromisso do Estado social, e ainda se mantém em um mundo da vida que deve fornecer o espaço para as intenções de uma democracia radical e do socialismo"

$\mathrm{Na}$ verdade, trata-se de uma contradição presente em toda sua obra e que ilumina seu propósito fundamental na tentativa de fazer uma teoria crítica da sociedade com interesses emancipatórios. Por essa razão, Habermas não pode se furtar a enfrentar tal contradição "se quiser ser ao mesmo tempo marxista e realista" ${ }^{87}$. Nas suas próprias palavras: "Eu penso que tenho sido um reformista por toda a minha vida, e talvez eu tenha me tornado ainda mais nos últimos anos. Entretanto, eu sinto muitas vezes que sou o último marxista. Na verdade, eu penso que há uma necessidade definitiva em considerar aqueles imperativos que ainda se reproduzem de acordo com o modo capitalista de acumulação e que resultam de um Estado capitalista altamente burocratizado para com isso enfrentá-los e revertê-los, ou ao menos modificar tais imperativos (...) Eu não acho que seja possível qualquer tipo de revolução em sociedades que têm um tal grau de complexidade; porém, nós não podemos recuar" ${ }^{\wedge 8}$. Isso seria possível porque a intenção de Habermas não é, de forma alguma, anular aquele espaço de autodeterminação do mundo da vida. Trata-se, ao contrário, de privilegiar a esfera da solidariedade no redirecionamento do equilíbrio de forças com as outras duas esferas de integração social. Em outras palavras, seria preciso mobilizar a arena inferior, em que se encontram fluxos difusos de comunicação cotidiana, em face das duas arenas superiores, compostas pelas elites políticas e pelos diversos grupos de interesse que formam coalizões e

\footnotetext{
${ }^{85}$ Tomberg, F. Habermas und der Marxismus, op. cit., p. 335.

${ }^{86}$ Idem, p. 317.

${ }^{87}$ Ibidem.

${ }^{88}$ Habermas, J. “Concluding remarks”. In: Calhoun, C. (ed.). Habermas and the public sphere, op. cit., p. 469.
} 
controlam a produção. Na arena inferior, diz Habermas, "não se luta diretamente por dinheiro ou poder, mas por definiçõos. Trata-se da integridade e da autonomia de estilos de vida, como, por exemplo, a defesa de subculturas tradicionalmente estabelecidas ou a transformação da gramática das formas de vida legadas (...) Essas lutas permanecem quase sempre latentes, elas têm lugar nos microdomínios da comunicação cotidiana, apenas de vez em quando se condensam em discursos públicos e em intersubjetividades de nível superior" ${ }^{\circ 9}$.

Essa característica dos movimentos sociais poderia ser esclarecida caso entendêssemos que o potencial emancipatório não será simplesmente identificado ao "componente ativo" da ação coletiva. É verdade que a racionalidade das ações não pode ser deduzida da racionalidade instrumental dos sistemas. Contudo, apenas a partir de uma teoria da ação, tal como fez Touraine, perde-se um ponto de partida fundamental que consiste em ancorar o potencial emancipatório na realidade de sociedades altamente complexas, e com isso não se enfrenta aquele dilema fundamental, a saber, "que o capitalismo desenvolvido nem pode viver sem o Estado social - e nem coexistir com sua expansão contínua" ${ }^{90}$. Pois as instituições do Estado social caracterizam um impulso no sistema político "para o qual não há alternativa visível em sociedades como a nossa"91 " "Eu acredito", comenta Habermas, "que há somente uma maneira de repelir as fronteiras (...) entre mundo da vida e sistema sem aquelas forças que historicamente se consolidaram como as mais prováveis - ou seja, sem armas, sem suborno nem dinheiro, sem repressão legal, etc. A única via consiste em radicalizar aquelas instituições que já se estabeleceram nos países ocidentais, dirigi-las para uma forma de democracia radical que torne possível (...) modificar ou ao menos afetar a administração" "92.

Essa radicalização dependeria, portanto, em admitir o elemento emancipatório difuso das mobilizações sociais e recuperar o potencial reflexivo das instituições democráticas sensíveis ao poder comunicativo. $\mathrm{O}$ acento na prática comunicativa seria reforçado na medida em que o discurso público manteria presente o sentido de uma esfera política intacta vinculada à negociação e definição das formas de vida estruturadas simbolicamente. Essa "reprodução auto-referencial da esfera pública”, comenta Habermas, "revela o lugar onde se refugiou a expectativa de uma auto-organização soberana da sociedade" ${ }^{93}$. A autodeterminação política atribuída às contestações das ações coletivas dos novos movimentos sociais seria interpretada a partir do "solo movediço da comunicação política":

\footnotetext{
${ }^{89}$ Habermas, J. "Die Krise des Wohlfahrtstattes und die Erschöpfung utopischer Energien”, op. cit., p. 159.

${ }^{90}$ Idem, p. 152.

${ }^{91}$ Ibidem.

${ }^{92}$ Habermas, J. "Concluding remarks", op. cit., p. 469-470.

${ }^{93}$ Habermas, J. "Volkssouveränität als Verfahren”, op. cit., p. 626.
} 
"A soberania, completamente fragmentada e espalhada aos quatro cantos, não consegue mais incorporar-se nas cabeças dos membros associados: ela pode aparecer, quando muito, nas formas de comunicação destituídas de sujeito, que regulam o fluxo da formação discursiva da opinião e da vontade (...) Ou seja, uma soberania popular que se tornou sem sujeito, anônima e diluída de modo intersubjetivista, se retira para os procedimentos democráticos e para os pressupostos comunicativos pretensiosos de sua implementação" 94 . Se o poder comunicativo puder influir no sistema político e acompanhar as decisões administrativas, seria possível submeter a moldura institucional, na qual se realiza atualmente o processo de legitimação, a uma avaliação crítica. Mas essa tradução das mobilizações sociais em termos de forças produtivas da comunicação só foi possível porque o sentido dos próprios procedimentos democráticos do Estado de direito consistiria na institucionalização das formas de comunicação necessárias para uma formação racional da vontade ${ }^{95}$. Podemos notar aqui uma tendência que levará Habermas a identificar o potencial emancipatório do poder comunicativo de esferas públicas com uma solução cada vez mais procedimental, tanto em relação aos procedimentos democráticos como aos pressupostos comunicativos a serem implementados. Os novos movimentos sociais, embora continuem tendo uma importância constitutiva para a teoria da ação comunicativa, precisariam ser reconstruídos de um ponto de vista normativo de modo que a a autodeterminação política pudesse encontrar seu potencial emancipatório nas formas de comunicação destituídas de sujeito.

Portanto, a autonomia dos estilos de vida, cuja definição precisaria ser constantemente negociada, desloca o acento utópico não apenas para o paradigma comunicativo. Exige, também, que a própria comunicação possa ser reconstruída segundo aspectos formais de uma intersubjetividade intacta. Por um lado, isso deixa mais claro que aquele núcleo normativo ausente em Touraine - correspondente à interpretação e avaliação dos movimentos sociais (ou seja, mais emancipatórios ou mais regressivos) - consistiria na possibilidade de reconhecimento intersubjetivo simétrico pressuposto pela ação comunicativa. Por outro lado, a própria definição de uma vida justa e igual, defendida pelo socialismo e também expressa em cada reivindicação social, teria de sofrer uma abstração radical. Pois a tarefa do teórico consistiria em deixar que os próprios indivíduos e grupos determinassem seu futuro. Marx e outros socialistas teriam pré-determinado as condições necessárias para formas de vida emancipadas de um modo muito concreto: diferentemente, a autonomia não seria realizada plenamente quando os sujeitos se reapropriassem das forças produtivas e controlassem

\footnotetext{
${ }^{94}$ Ibidem.

${ }^{95}$ Cf. Idem, p. 624.
} 
coletivamente os produtos (ou mesmo atividades) de sua cooperação social, pois o núcleo intencional que se estabelece nas relações sociais se encontraria na capacidade de regulação normativa da reprodução não apenas material, mas principalmente simbólica da vida em comum. Em outros termos: para ser considerada radicalmente democrática, uma teoria da emancipação teria de se limitar a apontar as condições necessárias para o desenvolvimento de uma existência humana livre e igual, embora tenha de deixar para os próprios concernidos determinar as fronteiras da auto-organização. Essa posição implicaria se centrar em questões procedimentais, mais do que se engajar em recomendações substantivas ${ }^{96}$. Também a pluralidade dos movimentos sociais não dificultaria somente a identificação do portador da emancipação com uma classe em especial, com aqueles atores privilegiados constitutivos dos tipos sociais, ou ainda prescrições substantivas de uma vida boa, mas exigiria uma indeterminação deste mesmo portador e uma justificação procedimental das regras práticas de sua conduta, sem que se perdesse, entretanto, uma perspectiva concreta a partir da qual a realidade fosse criticamente considerada. Nesse caso, a crítica de Habermas à teoria das classes, de acordo com a qual a análise permaneceria "presa a uma compreensão concretizante dos conflitos e dos agentes sociais, na medida em que opera com classes sociais e grandes sujeitos históricos como suportes do processo de produção e reprodução da sociedade"97, poderia valer, em certa medida, também para a sua pretensa sucessora.

2. Excurso: O conteúdo normativo do socialismo e a autonomia das formas de vida

Um dos passos mais importantes de uma autocrítica da esquerda não-comunista que se esquivava frente à obstinação realista dos defensores do socialismo realmente existente implicava em se perguntar "por quanto tempo uma idéia resiste à realidade" 98 . Pois é tão verdadeiro o argumento de que se não nos voltarmos ao ideal de formas de vida emancipadas perderíamos uma perspectiva crítica por meio da qual interpretamos a realidade, quanto também o fato de que os ideais precisam de um ancoramento no real para não perderem sua força orientadora da ação. O que essa necessária condição parece deixar claro é que o socialismo não pode ser considerado como se fosse uma idéia abstrata que paira sobre a

\footnotetext{
${ }^{96}$ Sitton utiliza nesse contexto o termo "socialismo procedimental". Cf. Habermas and contemporary society, op. cit., p. xv.

${ }^{97}$ Habermas, J. "Die nachholende Revolution und linker Revisionsbedarf: Was heißt Sozialismus heute?", op. cit., p. 190.

${ }^{98}$ Idem, p. 188.
} 
realidade, mas antes "constituir uma perspectiva a partir da qual a realidade é criticamente observada e analisada"99. Mesmo que possamos associar ao conceito de socialismo a intuição normativa de uma vida coletiva não violenta, possibilitando a realização individual e a autonomia, em harmonia com a solidariedade e a justiça, os ideais de uma forma de vida justa e igual deveriam ser não somente desenvolvidos como também corrigidos, permitindo a uma tal intuição normativa poder ser "corroborada indiretamente na força com que desvenda a realidade e no teor empírico da descrição teórica" ${ }^{100}$. Mas a perspectiva crítica não leva a que a interpretação da intuição normativa do socialismo se encontre diretamente enraizada em alguma forma de vida concreta a ser privilegiada, seja ligada a costumes e hábitos específicos, a certos valores de alguma comunidade frente a outras, ou mesmo a interesses de algum grupo ou classe em particular. Seria preciso ancorar as conotações normativas na realidade sem que se substancializasse e particularizasse um portador da emancipação em especial, um determinado modelo de sociedade emancipada e, por conseguinte, um sentido único de emancipação. E isso não é apenas uma conseqüência da práxis estabelecida a partir dos novos movimentos sociais, mas também uma exigência normativa incrustada nos potenciais emancipatórios da democracia radical. O ideal da soberania popular a ser recuperado precisaria ser descrito de forma plural com base em uma concepção de autodeterminação política que pudesse explicar a emergência dos movimentos sociais, seu conseqüente papel para a racionalização do poder político e sua articulação com as condições democráticas de institucionalização das práticas de ação coletiva.

É por essa razão que, diferentemente de Marx e de muitos de seus seguidores, passamos a não utilizar mais o termo sociedade emancipada quando nos referimos à orientação socialista, mas sempre formas de vida emancipadas. Pois sociedades complexas e pluralistas - perpassadas pelas diferenciações funcionais do mercado e do poder administrativo bem como pela pluralização das histórias de vida individuais e tradições coletivas - inviabilizariam a imagem de uma sociedade tomada em seu todo. Os socialistas de um modo geral pensaram a soberania popular como auto-organização coletiva entre indivíduos livres e iguais não apenas a partir de um ideal de autorealização ou pela utopia de uma socialização não-alienada, intencional e consciente. Toda a referência ao processo revolucionário pressupunha a imagem de um sujeito de nível superior que precisaria restituir

\footnotetext{
${ }^{99}$ Idem, p. 189.

${ }^{100}$ Ibidem.
} 
sua unidade alienada, de modo que a emancipação de uma classe pudesse representar simultaneamente a emancipação humana e sua efetivação na história universal ${ }^{101}$.

Além disso, a sociedade emancipada, interpretada com base no paradigma produtivista, revestiu a vida social com determinações demasiadamente substantivas. Ao pensar as condições de socialização consciente, Marx lançou mão da imagem de uma "associação de homens livres" 102 em que o processo de reprodução social e os problemas de integração se solucionassem na dimensão da coordenação funcional: a unidade da sociedade se exteriorizava como produto coletivo dessa associação livre, como produto social, uma vez que as condições plenamente transparentes da socialização consciente eram geradas pelos homens livres que trabalhavam com meios coletivos de produção, empregando suas forças de trabalho com plena "autoconsciência e como uma grande força de trabalho social" "103. O "reflexo religioso do mundo real", admite Marx, "poderá desaparecer para sempre somente quando as condições da vida prática diária que se efetiva no trabalho representarem para os homens relações claras e racionais entre si e a natureza. A forma do processo da vida social, ou seja, do processo material de produção, só se despojará de seu manto místico se esse processo for obra dos homens livremente socializados e colocado sob seu mando consciente e racional" ${ }^{\text {104 }}$. Delineia-se assim uma orientação prática em que se encontrão articuladas a autorealização e uma certa ética produtivista que contaminaria tanto o fundamento normativo da solidariedade quanto a diretriz propriamente política: "A lógica e a tarefa da acumulação", comenta André Gorz, “deviam ser subsumidas pelos próprios dirigentes operários e viu-se, assim, esses dirigentes, em todos os níveis, reinventarem uma ética produtivista que se assemelhava, em certos aspectos, à ética da burguesia puritana da época heróica do capitalismo. (...) Uma ética segundo a qual o homem não estava na terra para gozo e cultivo de seus sentidos, e sim para superar-se sempre pelo afã de trabalhar, subentendendo-se que recuperaria em um além, o da sociedade vindoura, o que sacrificava ali no momento"105. O socialismo relegou a segundo plano e "censurou, em sentido freudiano, as necessidades que não eram diretamente produtivas, isto é, cuja satisfação não era necessária à reprodução ou ao crescimento da força de trabalho"106. Isso foi possível porque a possibilidade de satisfação universal dos valores de uso atrelava a natureza das necessidades humanas àquela da

\footnotetext{
${ }^{101}$ Cf. Marx, K. Zur Kritik der Hegelschen Rechtsphilosophie. Einleitung. In: Marx-Engels Werke. Band 1, op. cit., p. 391; e Engels, F./Marx, K.. Deutsche Ideologie, op. cit., p. 35.

${ }^{102}$ Marx, K. Das Kapital, Vol. 1, op. cit., p. 92.

${ }^{103}$ Ibidem. (O grifo é nosso).

${ }^{104}$ Idem, p. 94.

${ }^{105}$ Gorz, A. O socialismo difícil. Tradução de Maria Helena Kühner. Rio de Janeiro: Zahar, 1968, p. 124.

${ }^{106}$ Ibidem.
} 
autoatividade produtiva. Por essa razão, mesmo na imagem de uma sociedade emancipada rapidamente aludida na Ideologia alemã, ações livres como o pescar e o criticar seriam entendidas a partir do intercâmbio infinito das tarefas de produção, administração, gestão e, por sua vez, de criação livre. O momento da abolição do trabalho implicaria igualmente uma divisão voluntária da autorealização entendida em termos de autoprodução ${ }^{107}$.

O conteúdo normativo dessa ética produtivista remete a uma certa continuidade entre a crítica tradicional dos males da sociedade e a nova crítica aos males específicos da sociedade burguesa. Há certamente uma distinção entre o que para Marx e também Engels consistia na sociedade justa e o chamado comunismo primitivo ${ }^{108}$. É preciso lembrar que já as primeiras críticas socialistas tiveram como matriz intelectual o iluminismo do século XVIII e sua respectiva idéia de progresso. Porém, o conceito de totalidade e a interpretação concretista da soberania popular, formulados em termos de autorealização, continuariam a fundamentar a utopia marxista da sociedade do trabalho autônoma e das formas de convivência solidária entre trabalhadores livremente associados. De Aristóteles manter-se-ia de forma concretista a imagem da boa vida e sua efetivação em uma totalidade substantiva, reflexo da idéia aristotélica de que a cidade seria condição da felicidade, de modo que a verdadeira realização da natureza do homem, que é política, se efetivaria na cidade ${ }^{109}$; além disso, a boa vida na cidade dependeria também das formas de solidariedade estabelecidas nas relações de amizade entre os cidadãos ${ }^{110}$. Rousseau foi outro autor a exercer um papel significativo na formação da teoria socialista moderna. Embora acreditasse que a propriedade privada seria fonte de desigualdade social, ele não afirmou que a sociedade justa deveria se fundar na socialização da propriedade; apesar disso, dele reteve-se a visão da igualdade social baseada na propriedade comum da riqueza distribuída e sobre a regulamentação centralizada de todo trabalho produtivo" ${ }^{111}$. Em segundo lugar, lembra Hobsbawm, "é inegável o influxo de igualitarismo rousseauniano sobre a esquerda jacobina"112. Por fim, Hegel foi um dos autores

\footnotetext{
${ }^{107}$ Cf. Engels, F./Marx, K. Deutsche Ideologie, op. cit., p. 33.

${ }^{108}$ Cf. Engels, F./Marx, K. Manifest der Kommunistischen Partei, op. cit., p. 491; e Draper, H. Karl Marx's theory of revolution IV: Critique of other socialisms, op. cit., capítulos 1 e 2.

${ }^{109}$ Cf. Hartmann, K. Die Marxsche Theorie. Berlin: Walter de Gruyter \& Co., 1970, p. 98-99. Em relação à teoria aristotélica, ver também Lopes, M. O animal político: Estudos sobre justiça e virtude em Aristóteles. São Paulo: Esfera Pública, 2008, capítulo II. A especial dívida de Marx em relação à teoria aristotélica atinge inclusive o conceito de ação autônoma como trabalho. Ernst Michael Lange mostra em seu livro que também o conceito de trabalho de Marx tem sua gênese na distinção dada por Aristóteles entre poiesis e praxis. Cf. Lange, E. M. Das Prinzip Arbeit, op. cit., p. 13-24.

${ }^{110}$ Cf. novamente Lopes, M. O animal político: Estudos sobre justiça e virtude em Aristóteles, op. cit., capítulo $\mathrm{V}$.

${ }^{111}$ Cf. Volpe, G. Rousseau e Marx: A liberdade igualitária. Lisboa: Edições 70, 1982, p. 89 e ss.

${ }^{112}$ Hobsbawm, E. "Marx, Engels, e o socialismo pré-marxiano". In: Hobsbawm, E. (org.). História do marxismo. Vol. I. Paz e Terra, 1979, p. 39.
} 
que mais claramente influenciou o núcleo normativo do socialismo, sobretudo nas obras de Marx. Pois a realização prática da liberdade dos indivíduos seria conquistada somente por meio da socialização das relações humanas e sua respectiva institucionalização, as quais foram tratadas por Hegel em seu conceito de Sittlichkeit, de eticidade, e que ganharia novas fomulações na antropologia filosófica com o conceito de "ser genérico" ou com o modelo da auto-organização holista dos trabalhadores. Apenas no âmbito da Sittlichkeit seria possível superar o egoísmo individualista e fundamentar a autonomia radical na comunidade racional em que a liberdade seria conquistada pelos indivíduos em associação e por meio da vida comunitária $^{113}$.

Em Aristóteles, Rousseau e Hegel seria possível encontrar elementos para uma crítica ao individualismo e ao modelo capitalista e liberal do mercado competitivo que apontassem para uma sociedade organizada com base em um modelo associacionista e estabelecido a partir da propriedade cooperativa. O que mais uma vez remeteria a uma dimensão concretista das condições emancipatórias: Marx e Engels "leram Rousseau e Hegel demasiadamente com os olhos de Aristóteles, menosprezaram a substância normativa do universalismo kantiano e do iluminismo e compreenderam erroneamente de um modo demasiado concretista a idéia de uma sociedade livre. Eles entenderam o socialismo como uma figura histórica privilegiada da eticidade concreta e não como um conjunto de condições necessárias para formas de vida emancipadas, sobre as quais os próprios participantes teriam de entrar em acordo" ${ }^{114}$. Para superar esse modelo de sociedade emancipada, precisaríamos submeter as conotações normativas do socialismo a uma abstração radical e levar a cabo seu conceito como um projeto no qual as próprias condições para formas de vida emancipadas estivessem abertas para constante negociação: “ainda que se conserve a crítica à dominação natural ilegítima e à velada violência social, o ponto central são aquelas condições de comunicação sob as quais se pode estabelecer uma justificada confiança nas instituições de auto-organização de uma sociedade de cidadãos livres e iguais" $" 115$. Assim, diferentemente daqueles que entenderam o socialismo como uma figura historicamente privilegiada, dotada de eticidade concreta, é preciso compreendê-lo como um conjunto de "condições necessárias para formas de vida emancipadas, sobre as quais os próprios participantes têm de se entender preliminarmente"116.

\footnotetext{
${ }^{113}$ Cf. Heller, A. "A herança da ética marxiana". In: Hobsbawm, E. (ed.). História do marxismo XII, Rio de Janeiro, Paz e Terra, 1988, p. 106 e ss. Var ainda Hartmann, K. Die Marxsche Theorie, op. cit., p. 146-149; e Flickinger, H- G. Marx e Hegel. Porto Alegre: L\&PM, 1986, p. 44 e ss.

${ }^{114}$ Habermas, J. "Volkssouveränität als Verfahren", p. 617.

${ }^{115}$ Habermas, J. “Die nachholende Revolution und linker Revisionsbedarf: Was heißt Sozialismus heute?”, op. cit., p. 195.

${ }^{116}$ Habermas, J. Faktizität und Geltung., op. cit., p. 12.
} 
Essas condições necessárias implicam, primeiramente, uma forma abstrata de solidariedade e também a necessidade da institucionalização dos procedimentos de formação democrática da opinião e da vontade, na qual vinculam-se o direito e a política.

A saída de Habermas consistiria em traduzir para a teoria do discurso a insistência socialista na crítica às formas de dominação incontroladas, não legítimas, sem que com isso ele estivesse repetindo as velhas "melodias do socialismo ético". Nesta tradução, a vida comum solidária que encontramos nas condições de sociedades modernas seria pensada segundo uma forma abstrata, porém não normativamente neutra. Tratar-se-ia das condições intersubjetivamente compartilhadas da comunicação, em que todos participariam dos procedimentos de uma formação política da opinião e da vontade e cujos processos de uma comunicação pública pudéssemos presumir mais ou menos racionais. Racionais na medida em que se apoiariam sobre o sentido normativo de procedimentos democráticos que teriam por função assegurar que todas as questões de importância político-social pudessem ser tematizadas, tratadas por meio de discursos e transformadas em soluções que - por respeitarem igualmente a integridade de cada indivíduo e cada forma de vida - são do interesse de $\operatorname{todos}^{117}$.

Nesse sentido, por trás de cada reivindicação concreta, incorporada nos mais diversos interesses e valores quando considerada substancialmente, seria possível reconstruir as condições para a emancipação de formas de vida de acordo com os pressupostos e procedimentos comunicativos que formam uma concepção abstrata de relações solidárias ${ }^{118}$. A solidariedade seria concebida a partir das condições simétricas de reconhecimento recíproco pressupostas na ação comunicativa. E o papel do teórico crítico se limitaria a tal reconstrução, pois há uma "tendência a conceber o socialismo como uma figura historicamente privilegiada da eticidade concreta, ainda que, na melhor das hipóteses, uma teoria possa indicar as condições necessárias para formas de vida emancipadas, cuja configuração concreta teria de ser primeiramente decidida pelos próprios concernidos"119. Essa decisão não implicaria em um fim último antecipado pelo teórico, mas a reconstrução das condições de uma comunicação livre de coerção já presentes na interação mediada pela linguagem: "a teoria social ultrapassaria os limites de sua competência se tomasse como tarefa

\footnotetext{
${ }^{117}$ Cf. Habermas, J. "Die nachholende Revolution und linker Revisionsbedarf: Was heißt Sozialismus heute?", op. cit., p. 195-196.

${ }^{118}$ Discutindo modelos de uma sociedade emancipada, Albrecht Wellmer faz uma comparação entre uma "sociedade sem classes" de Marx e uma "comunicação livre de coerção" de Habermas, em "Über Vernunft, Emanzipation und Utopie". In: Wellmer, A. Ethik und Dialog. Frankfurt/M, Suhrkamp, 1986, p. 175 e ss.

${ }^{119}$ Habermas, J. "Die nachholende Revolution und linker Revisionsbedarf: Was heißt Sozialismus heute?”, op. cit., p. 191. (O grifo é nosso).
} 
a projeção de formas de vida desejáveis no futuro, em vez de criticar as formas de vida existentes (...) Por esse motivo a teoria marxista não pode apresentar a expressão ‘socialismo’ em termos de uma forma de vida concreta. No melhor dos casos ela pode indicar as condições necessárias sob as quais formas de vida emancipadas seriam possíveis hoje"120.

Ora, a indeterminação quanto ao "portador da emancipação", por causa da emergência radical de várias esferas da vida social, leva-nos a desubstancializar as conotações normativas do ideal socialista de uma vida justa e igual dissolvendo-as naquelas relações solidárias simétricas apoiadas no reconhecimento recíproco. Certamente as condições para formas de vida emancipadas não estão limitadas às reconstruções mais abstratas da ação comunicativa, mas referem-se principalmente à auto-organização institucional através da qual a sociedade poderá se autodeterminar e aos movimentos e mobilizações concretos a partir dos quais a reconstrução teórica fundamenta suas interpretações. Em todo caso, o pressuposto de que existe algo como uma liberdade em relação à dominação seria constitutiva das práticas sociais daqueles que se engajam em processos de argumentação. Porém, Habermas admite que "seria uma falácia dizer que uma sociedade emancipada poderia consistir em nada mais do que em uma 'comunicação livre de dominação'. As pessoas que me imputam isso estão facilitando demais as coisas para elas mesmas" ${ }^{\prime 21}$. Pois a libertação de um potencial racional contido na ação comunicativa ocorre sempre por um processo histórico mundial, iniciado com a "verbalização do sagrado"; na modernidade tal processo conduziu a uma racionalização dos mundos da vida, à diferenciação de suas estruturas simbólicas, expressa principalmente na crescente reflexividade das tradições culturais, em processos de individuação, na generalização de valores, na imposição de normas mais abstratas e mais gerais, etc. A sociedade "única" não seria colocada em questão somente em face dos sistemas de coordenação funcional do dinheiro e do poder administrativo, mas também em razão desse processo de racionalização que ampliaria sensivelmente os sentidos da emancipação. Cada âmbito da estrutura simbólica do mundo da vida poderia conter ganhos e perdas em termos de emancipação que não se ligam necessariamente, ainda que criem elos de interdependência. A emancipação do indivíduo não levaria necessariamente à libertação de formas culturais; a conquista de direitos políticos e sociais não implicaria necessariamente ganhos em termos de autorealização individual, a qual também precisa ser conquistada por meio da crítica terapêutica; a autonomia da arte não levaria inevitavelmente à politização da economia ou à autodeterminação jurídico-política, etc. Existiriam antes emancipações parciais e plurais em

\footnotetext{
${ }^{120}$ Habermas, J. "Interview mit der New Left Review", op. cit, p. 237-238.

${ }^{121}$ Idem, p. 252.
} 
função de processos de modernização e racionalização complexos, ao mesmo tempo complementares e diferenciados - embora tendêssemos a ver na política e, principalmente, no uso público da razão, uma certa unidade para a multiplicidade de suas vozes ${ }^{122}$.

Também em outro sentido a libertação em relação à dominação não decorre simplesmente da comunicação livre. Considerações da história política e social constituem um pressuposto incondicional para que o núcleo normativo da reconstrução não se fundamente apenas com recursos à filosofia transcendental. Não podemos falar em "racionalização comunicativa", diz Habermas, "se nos últimos duzentos anos de história da Europa e da América, nos últimos quarenta anos dos movimentos de libertação nacional e, apesar de todas as catástrofes, não fosse possível também reconhecer um quê de 'razão existente', como diria Hegel - nos movimentos burgueses de emancipação não menos do que no movimento de trabalhadores, no atual feminismo, nas revoltas culturais, nas formas de resistência ecológica ou pacifista" ${ }^{\prime 23}$. Se não for pela possibilidade de realizar as condições de uma formação radicalmente democrática da vontade, hoje nos resta somente a imagem de um socialismo cuja possibilidade histórica foi completamente desmentida pelo socialismo realmente existente. E ao falar de "socialismo" essa imagem histórica é deixada de lado e substituída pelas conotações normativas pressupostas na autonomia das formas de vida, a partir da qual seria possível transformar "a riqueza social e as liberdades políticas das democracias de massa no pluralismo radical e nas práticas autônomas de uma sociedade que merece ser chamada de uma sociedade fundamentalmente democrática" ${ }^{, 24}$.

3. A esfera pública e o processo de circulação do poder político

Na caracterizazão da soberania popular como autodeterminação, auto-organização e como constituída por formas de solidariedade tentamos não deixar de lado um problema crucial. Os movimentos democráticos contemporâneos e suas lutas por novas formas de discurso, associações e direitos não poderiam ser explicados se lhes atribuíssemos o mesmo impulso pela totalização presente nas utopias revolucionárias. Em vez de apostar simplesmente em uma autoatividade sem limites, que diluiria toda diferenciação entre

\footnotetext{
${ }^{122}$ Essa poderia ser uma possível interpretação da idéia da esfera pública como o conteúdo normativo da modernidade. Cf. Habermas, J. Der philosophische Diskurs der Moderne, op. cit., capítulo XII; e Repa, L. A transformação da filosofia em Jürgen Habermas: Os papéis de reconstrução, interpretação e crítica, op. cit., capítulo 4.

${ }^{123}$ Ibidem.

${ }^{124}$ Habermas, J. "Interview mit Hans Peter Krüger", op. cit., p 92.
} 
sociedade civil, Estado e economia na dimensão mais utópica da solidariedade, seria preciso reformular o projeto político de democracia radical de acordo com um princípio de autolimitação $^{125}$. Tal princípio pressuporia uma diferenciação entre a dimensão da ação coletiva e os sistemas funcionais que, segundo Cohen e Arato, teria de ser sublinhada igualmente em razão de seus ganhos descritivos e normativos: trata-se de atentar antes aos movimentos que procuram "expandir e proteger tanto os espaços de liberdade negativa como positiva e recriar formas igualitárias de solidariedade sem inviabilizar a autoregulação econômica" ${ }^{\text {126 }}$. Para tanto, as próprias mobilizações pressuporiam conexões com a economia (sem que isso implique a aceitação da sociedade civil como sociedade econômica e individualista) e com o Estado, conexão que envolveria direitos de comunicação, asseguraria esferas associativas e debates públicos bem como direitos individuais e de privacidade. Evitar-se-ia, desse modo, projetos com conseqüências totalitárias que ao suprimirem a burocracia, a racionalidade econômica e também a divisão social acabariam por aniquilar toda forma de cooperação social baseada na institucionalização da liberdade e da igualdade.

Já a pluralidade de perspectivas, questões e atores articulada nos movimentos sociais poderia ser traduzida e reconstruída em termos de processos formadores da opinião e da vontade capazes de se diluir em esferas públicas autônomas que liberam, modificam e filtram criticamente o leque de temas, valores e argumentos canalizados pelos meios de comunicação de massa, por redes de associação direta ou pela comunicação cotidiana ativa e difusa. Como apontou Alberto Melucci, "um novo espaço político é designado para além da distinção tradicional entre Estado e 'sociedade civil': um espaço público intermediário cuja função não consiste em institucionalizar os movimentos nem transformá-los em partidos, mas fazer com que a sociedade escute suas mensagens e as traduza em tomada de decisão política, enquanto os movimentos mantêm sua autonomia"127. A primeira característica da esfera pública entendida como um "fenômeno social elementar, tal como ação, ator, grupo ou coletividade" ${ }^{\prime 28}$ - consistiria assim na sua dimensão de racionalização do poder político, de modo que o "público" fosse entendido como o portador de uma opinião pública com funções

\footnotetext{
125 O Grupo Solidariedade falava estrategicamente em nome de uma "revolução autolimitadora", dando a entender que a mobilização formada por grupos e associações vindos "de baixo" não pretendia substituir o Estado e o mercado. O processo de democratização precisaria romper com a orientação revolucionária extremada e, por sua vez, temida, insistindo por isso nos perigos de uma "desdiferenciação" que se tornaria incompatível com a auto-organização democrática da sociedade. Cf. Webbeler, N. Die Gründung der Solidarnosc - Beginn der Demokratisierungsbewegung in Polen: Hintergründe und Rahmenbedingungen, op. cit., p. 25 e ss. Ver também Arato, A./Cohen, J. Civil society and political theory, op. cit., p. 31-36.

${ }^{126}$ Arato, A./Cohen, J. Civil society and political theory, op. cit., p. 17-18.

${ }^{127}$ Melucci, A. "The symbolic challenge of contemporary movements", op. cit., p. 815.

${ }^{128}$ Habermas, J. Faktizität und Geltung, op. cit., p. 435.
} 
de crítica $^{129}$. A segunda característica torna possível vislumbrar o papel de mediação presente na estrutura social e política de sociedades altamente complexas, pois "há de se manter a distinção", comenta Sérgio Costa, "entre a esfera societária e a esfera política e o Estado, de sorte que a influência da sociedade civil se concretize de forma anônima e difusa por meio da existência de uma esfera pública transparente e porosa, permeável às questões originadas no mundo da vida. Somente através da mediação dos processos institucionais de formação da opinião e da vontade é que o poder de influência da sociedade civil deve chegar ao Estado"130. Por fim, ao diluir-se em formas de deliberação, que podem se cristalizar nas diferentes demandas e tematizações, ocorre assim um desacomplamento entre cultura e estruturas de classe, pois os discursos se difundem em amplas condições de participação, evidenciando a característica porosa da opinião pública e o fato de seguir procedimentos democráticos de deliberação ${ }^{131}$

As determinações conceituais e o núcleo normativo da esfera pública se deixam notar nos processos de formação política da opinião e da vontade, em que se entrecruzam os procedimentos de deliberação pública juntamente com a dinâmica da circulação do poder político. Nos trabalhos de Habermas e, sobretudo, de Bernhard Peters encontram-se articulações teóricas e descrições ricas para a análise dos discursos públicos, das funções, potenciais e níveis de racionalidade presentes nos procedimentos de deliberação pública, da capacidade de reprodução cultural e da formação de uma cultura pública, dos processos de aprendizado, dos aspectos dinâmicos dos mecanismos de seleção de temas e contribuições, bem como dos processos de integração social e de legitimação política centrados na esfera pública $^{132}$. As exigências normativas da soberania popular são sintetizadas nas determinações do conceito de esfera pública uma vez que a autonomia é traduzida em termos kantianos como a possibilidade que os cidadãos possuem para obedecer estritamente às leis e normas que

\footnotetext{
${ }^{129}$ Cf. Habermas, J. Strukturwandel der Öffentlichkeit, op. cit., p. 55.

${ }^{130}$ Costa, S. As cores de Ercília: Esfera pública, democracia, configurações pós-nacionais. Belo Horizonte: UFMG, 2002, p. 26.

${ }^{131}$ Habermas, J. Faktizität und Geltung, op. cit., p. 435 e ss.

${ }^{132}$ Cf. Peters, B. Der Sinn von Öffentlichkeit. Frankfurt/M: Suhrkamp, 2007; Habermas, J. Strukturwandel der Öffentlichkeit, op. cit.; Habermas, J. Faktizität und Geltung, op. cit., capítulo 8; Habermas, J. "Hat die Demokratie noch eine epistemische Dimension? Empirische Forschung und normative Theorie". In: Habermas, J. Ach, Europa. Frankfurt/M: Suhrkapm, 2008. Ver também Gerhards, J. "Politische Öffentlichkeit. Ein systemund akteurstheoretischer Bestimmungsversucht”. In: Friedrichs, J./Leosius, R./Neidhart, F. (org.). Öffentlichkeit, öffentliche Meinung, soziale Bewegung. Westdeutscher Verlag, 1994, p. 77-105; Bohman, J. Public deliberation, op. cit.; Calhoun, C. (ed.). Habermas and the public sphere, op. cit.; Costa, S. As cores de Ercília: Esfera pública, democracia, configurações pós-nacionais, op. cit; Baynes, K. The Normative grounds of social criticism, Kant, Rawls, and Habermas. New York: Albany, 1992, principalmente último capítulo.
} 
poderiam aceitar com boas razões com base em um uso público da razão ${ }^{133}$. A tematização pública revela uma estrutura simbólica ilimitada, que transita entre os aspectos normativos dos discursos racionais, deliberações e justificações da legitimidade até mobilizações nãodiscursivas, tipos e gêneros de atividades sociais e culturais, cultura de fundo, etc ${ }^{134}$. Já as distinções empíricas que o conceito abrange incluem estruturas sociais e funções da esfera pública, tais como as categorias de participação, estruturas de produção e criação de meios de comunicação, segmentação e estratificação social, diferenciações entre esferas públicas nacionais, a existência de esferas públicas transnacionais, etc ${ }^{135}$. Desse modo, a circulação complexa do poder político envolveria a deliberação pública (em esferas públicas formais e informais) assim como uma cultura pública (em que se identificam e colidem valores e temas comuns, imagens familiares à cultura de fundo - expressas em filmes, música, teatro, literatura, jornais, televisão, etc. - o público de especialistas, a percepção de um horizonte histórico e espacial comum, a elaboração de convicções, os laços culturais das tematizações que se transformam em opinião pública, etc $)^{136}$.

A própria deliberação pública pode ser reconstruída em razão dos procedimentos democráticos e da diferenciação interna de seus discursos, como ainda veremos, ou de acordo com os deslocamentos temáticos e participativos colocados em circulação no processo de formação da opinião e da vontade. Pois as tomadas de decisão política pretensamente legítimas geralmente são precedidas pelos fluxos comunicativos gerados em esferas públicas informais, e estas, por seu turno, podem qualificar e influenciar o conjunto de justificação das corporações parlamentares, do judiciário, etc ${ }^{137}$. Certamente que esse modelo de circulação do poder, entendido como a tradução do poder comunicativo em poder administrativo, pressupõe um processo complexo e dinâmico permeado não apenas pela luta social e pela esfera

${ }^{133}$ Cf. Rawls, J. “A idéia de razão pública revisitada”. In: Melo, R. S./Werle, D. L. (org.) Democracia deliberativa, op. cit., p. 145-192. Ver ainda Werle, D. L. Justiça e democracia: Ensaios sobre John Rawls e Jürgen Habermas, op. cit.; e Melo, R. S. O uso público da razão como procedimento: Pluralismo, discurso e democracia em Habermas, op. cit.;

134 Cf. Peters, B. "Über öffentliche Deliberation und öffentliche Kultur". In: Peters, B. Der Sinn von Öffentlichkeit, op. cit., p. 103 e ss.

135 Cf. idem, p. 122 e ss. Também Peters, B. "Nationale und transnationale Öffentlichkeiten - eine Problemskizze". In: Peters, B. Der Sinn von Öffentlichkeit, op. cit., p. 283-296; Costa, S. As cores de Ercília: Esfera pública, democracia, configurações pós-nacionais, op. cit., capítulo VIII.

${ }^{136}$ Cf. Peters, B. "Über öffentliche Deliberation und öffentliche Kultur”, op. cit., p. 106-116. Ver também Taylor, C. "A política liberal e a esfera pública”. In: Taylor, C. Argumentos filosóficos. São Paulo, Loyola, 2000, p. 278 e ss.

${ }^{137}$ Cf. a pesquisa piloto sobre os nexos entre esfera pública e legislação antiracismo em Costa, S./Lusci, E. C./Melo, R. S./Machado, M./Machado, M. R./Repa, L./Silva, F. G./Spécie, P./Werle, D. L.: "Para além da inefetividade da lei? Estado de direito, esfera pública e anti-racismo". In: Lavalle, A. G. (org.) O horizonte da política: questões emergentes e agendas de pesquisa. São Paulo: Cosac \& Naify, 2009. Ver também Machado, M. R./Melo, R. S./Silva, F. G. "The public sphere and the antiracism legal protections in Brazil". In: Social Science Research Network, Março de 2008. 
pública ${ }^{138}$, mas também pela interdependência e constituição recíproca entre política e direito $^{139}$. Em todo caso, é possível distinguir na relação entre sociedade civil e Estado as esferas públicas formais e informais, que refletiria a diferenciação proposta por Nancy Fraser entre públicos fortes e fracos $^{140}$.

Podemos diferenciar, portanto, mobilizações e tematizações - sejam discursivas ou não - que ocorrem no âmbito da formação da opinião informal, por um lado, da composição e do modo de trabalho de associações e instituições ligadas mais diretamente ao Estado, por outro lado. Essa dimensão formal da esfera pública, que incluiria não apenas a divisão de poderes como também aquelas associações capazes de institucionalizar certas reivindicações com mais eficácia para a solução de problemas - como é o caso da sociedade civil, capaz de condensar e transmitir questões de interesse geral diluídas na opinião pública para a esfera pública política - constituem um ponto de referência fundamental para a organização propriamente argumentativa de negociações específicas: os procedimentos democráticos estabelecidos na arena formal estruturam institucionalmente os processos políticos de formação da opinião e da vontade com a finalidade de produzir soluções mais coopertivas de conflito e de negociação de compromissos eqüitativos. Conforme sugere Fraser, a esfera pública formal, composta dos públicos fortes, não pressupõe uma separação rígida entre Estado e sociedade, de modo que a soberania popular possa ser interpretada a partir da ação da esfera pública no interior do Estado ${ }^{141}$. Neste caso, a própria sociedade civil recebe uma interpretação menos liberal, embora continue se diferenciando da economia e do poder administrativo. O mais decisivo consistiria em entender que as questões da esfera pública formal, que se condensam a partir das associações civis, não estancam no processo de formação da opinião, pois os públicos fortes "abrangem tanto a formação da opinião quanto a tomada de decisão" ${ }^{142}$. O locus da razão pública, quando adquire os contornos das regulações formalizadas, desloca o peso da justificação normativa da identificação de problemas, em que todos os cidadãos participam nos processos de descobertas e novas colocações de questões práticas, para o momento da seleção e decisão de propostas concorrentes ${ }^{143}$.

\footnotetext{
${ }^{138}$ Cf. Lubenow, J./Neves, R. "Entre promessas e desenganos: lutas sociais, esfera pública e direito”. In: Nobre, M./Terra, R. (org.). Direito e democracia: Um guia de leitura de Habermas, op. cit., p. 249-267.

${ }^{139}$ Cf. Soares, M./Werle, D. "Política e direito: A questão da legitimidade do poder político no Estado democrático de direito". In: Nobre, M./Terra, R. (org.). Direito e democracia: Um guia de leitura de Habermas, op. cit., p. 117-145.

${ }^{140}$ Cf. Fraser, N. "Rethinking the public sphere". In: Calhoun, C. (ed.). Habermas and the public sphere, op. cit., p. 132-136. Sobra a distinção entre esferas públicas formais e informais, ver Habermas, J. Faktizität und Geltung, op. cit., p. 372 e ss, e 435 e ss.

${ }^{141}$ Cf. Fraser, N. "Rethinking the public sphere", op. cit., p. 134.

${ }^{142}$ Ibidem.

${ }^{143}$ Cf. Habermas, J. Faktizität und Geltung, op. cit., p. 372 e ss.
} 
Diferentemente dos públicos fortes - que se estruturam quase sempre em torno do conjunto de justificação de decisões de esferas públicas formais, compostas principalmente de corporações parlamentares, da esfera do judiciário e da administração - , Fraser sublinha que os públicos fracos se formam na periferia do Estado e não podem exercer poder político direto nos processos de tomada de decisão. Na verdade, a força que o público fraco possui dependeria da possibilidade de ver sua opinião pública reforçada por órgãos capazes de traduzir tal opinião em decisões políticas efetivas ${ }^{144}$. Não parece evidente que a formação da opinião desatrelada das decisões continue sendo um componente ativo do campo do político. Contudo, é justamente essa desubstancialização da soberania popular, que passa a se realizar amplamente em uma rede pública e inclusiva de esferas públicas plurais e sobrepostas, com fronteiras sociais e culturais bem fluidas, que permite que a autonomia política não seja substituída por reformas meramente administrativas: os componentes informais próprios de esferas públicas plurais permitem uma formação porosa da opinião e, por conseguinte, uma reprodução espontânea de formas de vida que não se deixam organizar completamente. Evidenciaria-se um elemento positivo da reprodução de formas individualizadas de vida por meio de estruturas comunicativas generalizadas, uma vez que o fardo de decisões em torno da autorealização não exigiria que as orientações formadas muitas vezes em anonimato fossem traduzidas em códigos especiais e linguagens de especialistas, ou seja, em decisões que exigem um grau maior de explicação e responsabilização. Os processos de formação da opinião são acompanhados de processos de aprendizagem e de mudanças de preferência e enfoque por parte de indivíduos que podem viver com certa dose de indiferenciação. "Nesta medida", comenta Habermas, "as estruturas comunicativas da esfera pública aliviam o público de tomar decisões; as decisões proteladas permanecem reservadas às instituições responsáveis pelas resoluções" ${ }^{\prime 145}$.

Ora, essa perspectiva dinâmica para a compreensão da circulação do poder resguarda a política, o direito e a própria esfera pública como centros de auto-organização, mantendo a política e o direito como campos institucionais e o sistema de governo como núcleo institucional. Além desse âmbito formal, atribui-se um espaço fundamental para as demandas não-institucionais, principalmente às esferas associativas e ao conjunto de mobilizações nãoestatais por definição. Porém, as exigências da razão pública não se alojam no campo institucional somente do ponto de vista crítico-normativo, mas também ao circularem por um sistema jurídico-político que se coloca em relação de mediação com estruturas periféricas e

\footnotetext{
${ }^{144}$ Cf. Fraser, N. "Rethinking the public sphere", op. cit., p. 134-135.

${ }^{145}$ Habermas, J. Faktizität und Geltung, op. cit., p. 437.
} 
processos de formação da opinião, criando assim um espaço em que se formam convicções, articulam-se temas ou problemas e decisões são tomadas. Não se negaria assim a existência de algo como um poder comunicativo gerado no interior do próprio complexo parlamentar ou mesmo do judiciário, ou da influência da autodeterminação na esfera pública política. Pois embora os sistemas de ação funcionalmente especializados sejam independentes da interação social fundada em processos de entendimento, os meios de regulação continuam ancorados no componente social de esferas públicas.

Bernhard Peters forneceu um modelo de circulação do poder entre centro e periferia no qual descreve a possibilidade e os limites da assimilação dos conflitos na articulação entre esfera pública e sistema político ${ }^{146}$. Esse modelo propõe uma imagem alternativa e menos estanque da anatomia social do que aquela sugerida por Marx entre base econômica e superestrutura política, em que a sociedade civil se vê entregue aos imperativos de autovalorização do capital ou à ideologia burguesa que manipula o sistema jurídico-político para a autoestabilização de interesses capitalistas. O ponto de partida de Peters para a descrição do núcleo institucional não difere da tradicional divisão de poderes que conhecemos desde Montesquieu, consistindo em um complexo de centros institucionais diferenciados, policêntricos e independentes. Porém, a novidade do modelo consiste em mostrar, primeiramente, que o próprio centro (em que se encontram a administração, o judiciário e as muitas corporações parlamentares, eleições políticas, concorrência entre partidos, etc.) se ramificaria de acordo com a capacidade de ação e a densidade da complexidade organizatória, tais como a percepção e a tematização de problemas sociais ${ }^{147}$. E essa descrição do funcionamento e das atividades ramificadas já abrangeria, além disso, estruturas intermediárias de organização, ou seja, estruturas periféricas, dentre as quais se incluiriam os "processos de formação política da opinião e da vontade e as correspondentes estruturas institucionais (partidos e outras organizações), atividades jurídicas além daquelas do legislativo e do judiciário (a ciência jurídica, consultoria jurídica, firmas de direito privadas) ou os papéis dos grupos de interesse em face da administração e do parlamento" ${ }^{148}$. Tais estruturas intermediárias têm uma função de articulação de problemas e formulações de políticas que competem ao espectro de partidos, grupos de interesse e movimentos sociais, os quais também se diluem no âmbito da opinião pública ou se condensam na esfera pública política através de meios de comunicação de massa, pesquisa de opinião, uma multiplicidade

\footnotetext{
${ }^{146}$ Cf. Peters, B. Die Integration moderner Gesellschaften, op. cit., capítulo 9.

${ }^{147}$ Cf. idem, p. 330-336.

${ }^{148}$ Idem, p. 337.
} 
de redes de comunicação e públicos que se cristalizam em temas e publicações atuais, contextos de discussão determinados, etc ${ }^{149}$.

Os processos de comunicação e de decisão do sistema político são descritos por Peters segundo a imagem de um modelo de eclusas. Neste modelo, "temos a imagem de uma transposição das eclusas representadas pelos procedimentos democráticos do Estado constitucional, com o que os influxos do poder comunicativo, oriundos da periferia, atingem o centro do sistema político (parlamento, tribunais e administração)" ${ }^{\text {150 }}$. As eclusas funcionam, na verdade, como um sistema de comportas que podem ser transpostas permitindo uma interconexão entre o núcleo institucional e os influxos da esfera pública. Vê-se que as comportas representam, no modelo de eclusas, barreiras e estruturas de poder presentes na esfera pública e nos centros de poder político, as quais, para serem superadas, dependem das mobilizaçãos e manifestações de revolta que em momento crítico atingem um grau de tal modo intenso na esfera pública a ponto de modificar as relações de força entre a sociedade civil e o sistema político; e também da possibilidade que o próprio Estado de direito possui para regular os fluxos de poder que atravessa tal sistema. Em todo caso, afirma Peters, "a legitimidade das decisões depende dos processos de formação da opinião e da vontade na periferia. O centro é um sistema de comportas a ser atravessado por muitos processos no âmbito do sistema jurídico-político, mas o centro controla a direção e a dinâmica desses processos apenas de forma limitada. As mudanças podem partir tanto da periferia quanto do centro, e se pode também deixar de sempre atribuir ao centro institucional um primado causal nesse percurso. Muitas modificações do direito, por exemplo, produzem-se essencialmente nas estruturas informais da periferia na forma de mudanças na consciência jurídica ou das práticas correspondentes - mudanças que precisam ser ratificadas no fim pelas instituições autorizadas. A idéia de democracia repousa, em última instância, no fato de que os processos

\footnotetext{
${ }^{149}$ Cf. idem, p. 339-340. Ver ainda Gerhards, J. "Politische Öffentlichkeit. Ein system- und akteurstheoretischer Bestimmungsversucht”, op. cit., p. 97 e ss; e Peters, B. "Der Sinn von Öffentlichkeit”. In: Peters, B. Der Sinn von Öffentlichkeit, op. cit., p. 68 e ss. Ambos os autores se preocupam em distinguir os pressupostos normativos da esfera pública (tais como o princípio da igualdade e da reciprocidade, a estrutura discursiva, etc.) da descrição empírica na qual é fundamental atentar à capacidade de adequação do sistema político em face do influxo social. Contudo, ainda que problemas como estratificação social e estruturas de poder político (e mesmo a repartição social do saber, etc.) constituam um obstáculo à livre circulação de temas e à força da influência da periferia sobre o centro, as estruturas intermediárias têm a vantagem de já se instalarem em mecanismos de funcionamento do núcleo institucional (seja funcionalmente ou em razão das redes de comunicação). Neste caso, o direito e os meios de comunicação são mediações privilegiadas quando se trata de ancorar as pretensões da esfera pública na dimensão formal do poder político. Sobre a influência de Peters na formulação da relação entre esfera pública, democracia e comunicação de massa, ver Habermas, J. "Hat die Demokratie noch eine epistemische Dimension? Empirische Forschung und normative Theorie”, op. cit., p. 138-191.

${ }^{150}$ Repa, L. "Direito e teoria da ação comunicativa", op. cit., p. 69.
} 
de formação política da vontade, que no esquema aqui esboçado possuem um status periférico e intermediário, devem ser decisivos para o desenvolvimento político" ${ }^{\prime 151}$.

Do ponto de vista da eficácia, a opinião pública informal teria a capacidade de influenciar o centro. Contudo, isso não significa que o poder da opinião pública substituiria o sistema político, restringindo-se antes à influência e limitação do poder administrativo. É nesse sentido que entedemos a esfera pública, lembra Charles Taylor, como um discurso "fora do poder, que não obstante é normativo para o poder"152. Por essa razão, essas relações entre centro e periferia e a descrição empírica dos processos de assimilação de problemas no sistema político consistiriam, aos olhos de muitos, em uma concessão desnecessária à triste condição das democracias capitalistas realmente existentes ${ }^{153}$. Mas além de admitir uma dose necessária de realismo para que o potencial teórico e prático da crítica social encontre um ancoramento nos processos reais por meio dos quais as sociedades contemporâneas se reproduzem - tal como pretendeu Marx ao formular sua teoria da emancipação a partir das condições capitalistas - , o modelo de circulação do poder sugerido por Peters possibilita descrever e analisar a dinâmica dos debates e conflitos desencadeados em arenas formais e informais de discussão no quadro do Estado constitucional e das democracias de massa, permitindo entender como, a partir da participação em tais debates, a esfera pública pode exercer influência, por exemplo, sobre o processo legislativo, as ações do executivo ou a maneira como uma determinada norma ou lei é interpretada no âmbito do judiciário, etc. Esse processo de influência, fundamental para entender as lutas por emancipação, percorre a formação da opinião em espaços públicos informais (nas quais questões controversas passam a ser tematizadas publicamente), adentram as arenas formais de deliberação (onde determinados temas são sistematizados na legislação), chegando também à esfera de aplicação no judiciário e na administração. Nesse caso, o exercício da soberania popular como procedimento seria constituído, portanto, a partir de uma relação de mão-dupla entre centro e periferia - e isso tanto entre o processo legislativo e as discussões públicas (na medida em que o legislativo pode reagir aos debates públicos e os processos legislativos podem criar ondas de discussão de temas diversos no âmbito da esfera pública) ou nas relações entre a esfera pública e executivo, esfera pública e judiciário, etc ${ }^{154}$. Se deixarmos de lado a idéia de que a

\footnotetext{
${ }^{151}$ Peters, B. Die Integration moderner Gesellschaften, op. cit., p. 340-341.

152 Taylor, C. “A política liberal e a esfera pública”, op. cit., p. 284.

${ }^{153}$ Como já havíamos chamado atenção ao artigo de Scheuerman, W. "Between radicalism and resignation: Democratic theory in Habermas's Between facts and norms", op. cit., p. 75.

${ }^{154}$ Cf. Costa, S./Lusci, E. C./Melo, R. S./Machado, M./Machado, M. R./Repa, L./Silva, F. G./Spécie, P./Werle, D. L.: "Para além da inefetividade da lei? Estado de direito, esfera pública e anti-racismo". Ver também Machado, M. R./Püschel, F./Rodriquez, J. R. "The juridification of social demands and the aplication of the
} 
emancipação só poderia ser pensada a partir de uma totalidade (um sujeito revolucionário, um partido, um Estado, uma sociedade, etc.), passa a ser crucial não apenas a sensibilidade pela diversidade de questões e atores que lutam por mais autonomia, liberdade e igualdade, mas também a percepção dos caminhos, obstáculos e potenciais existentes em sociedades complexas sem os quais não seria possível orientar a própria ação em direção a conquistas efetivas.

\section{II - Interdependência e relação recíproca entre política e direito}

O paradigma produtivista enfraqueceu as expectativas normativas da soberania popular contidas na experiência e na teoria das democracias ocidentais de duas formas: atribuindo-lhes um papel meramente instrumental, de modo que o conteúdo legítimo da democracia fosse reservado apenas à auto-organização dos trabalhadores associados; ou interpretando tais expectativas na forma da justiça social assegurada pelo Estado através de prestações distribuídas, transformando os destinatários dos direitos sociais em meros clientes das burocracias. A força histórica desse segundo caso consiste em ter se consolidado ao lado do liberalismo como uma condição indispensável de uma sociedade econômica de capitalismo industrial que só poderia se estabilizar com intervenção estatal. Sua fraqueza consistiu em ter cometido o mesmo erro da concepção liberal ao reduzir a cidadania ao gozo passivo da satisfação de interesses individuais. Assim, tanto no caso da orientação revolucionária como da reformista ocorreu uma redução da autonomia em razão de uma imagem produtivista. As críticas levantadas às duas concepções de emancipação apontavam para a possibilidade de uma restituição da autonomia que pudesse ser recuparada não mais com base no paradigma da produção, mas sim a partir de uma reconstrução das condições de uma democracia radical que ainda orientariam a autocompreensão política de sociedades modernas. No primeiro caso, lembra Habermas, "não é o controle comum da cooperação social que forma o núcleo da socialização intencional, mas sim uma regulação normativa da vida em comum, que pode contar com o assentimento de todos e garante as relações inclusivas de reconhecimento recíproco simétrico (e com isso a integridade de cada um dos indivíduos)"155. No segundo caso, em oposição às reformas que cristalizam o papel do cidadão na forma do interesse de clientes, ou seja, empurram "os cidadãos para o papel periférico de meros membros da

statutes: An analisys of the legal treatment of antiracism social demands in Brazil". In: Fordham Law Review, 77, 2009.

${ }^{155}$ Habermas, J. Faktizität und Geltung, op. cit., p. 393. 
organização" ${ }^{\prime 156}$, assevera-se o modelo de uma comunidade de direito que se autodetermina por meio da prática dos cidadãos. Nos dois casos, portanto, seria preciso juntar novamente aquilo que a tradição da esquerda havia separado e que em suas próprias interpretações pôde ser realizado apenas parcialmente, a saber, uma relação mais aberta e reflexiva entre a autodeterminação política e a auto-organização de uma comunidade de direito ${ }^{157}$.

\section{O modelo procedimental de política deliberativa}

O ponto de partida para a análise da situação da democracia de massas do Ocidente capitalista consiste em admitir que a democracia, a despeito da amplitude sem precedentes de sua adoção e das formas de sua implementação, vem perdendo sua vitalidade. Conforme esse diagnóstico, os mecanismos democráticos clássicos de expressão da soberania popular se limitam aos imperativos das eleições competitivas de partidos e líderes políticos em busca de cargos legislativos e executivos e subordinam-se à forma de organização burocrática do sistema administrativo do Estado. Esses mecanismos de representação inibiriam o interesse pela política ao engessarem a participação democrática nos canais institucionalizados, impedindo a tomada de decisões políticas fundadas na discussão pública aberta e dinâmica entre os cidadãos ${ }^{158}$. Assim, as possibilidades de formação espontânea da opinião pública e da vontade coletiva teriam sido limitadas pela segmentação do papel de eleitor, pela concorrência entre as elites dos partidos, pela estrutura vertical dos processos de formação da opinião pública dentro dos aparelhos partidários burocratizados, pela autonomização dos grêmios parlamentares e pela excessiva concentração de poder sobre os instrumentos de comunicação pública $^{159}$. Nesse sentido, a crítica à configuração meramente liberal de democracia, efetuada pela esquerda revolucionária e reformista, é de certo modo continuada pelas lutas sociais contemporâneas, embora tivesse de ser compreendida por ser agora simultaneamente mais abrangente e mais restrita: mais abrangente porque também o Estado social se transformou em

\footnotetext{
${ }^{156}$ Idem, p. 105.

${ }^{157}$ Uma tentativa particularmente interessante já havia sido formulada em Neumann, F. The rule of law. Political theory and the legal system in modern society, op. cit. Uma atualização dessa abordagem se encontra em Rodriguez, J. R. Fuga do direito - Um estudo sobre o direito contemporâneo a partir de Franz Neumann. Saraiva, 2009. Contudo, em ambos os autores faltaria uma teoria da democracia que também pudesse descrever a relação entre política e direito.

${ }^{158} \mathrm{Cf}$. Bessete, J. The mild voice of reason. Deliberative democracy and american national government. Chicago: Chicago University Press, 1994, introdução; Gutmann, A. "A desarmonia da democracia". In: Lua nova, 36, 1995; Bohman, J. Public deliberation, op. cit., introdução; e Melo, R. S./Werle, D. L. (org.) Democracia deliberativa, op. cit., apresentação.

${ }^{159}$ Cf. Peters, B. Rationalität, Recht und Gesellschaft, op. cit., capítulo V.
} 
obstáculo à realização da liberdade e da igualdade; mais restrita porque as condições de uma plena realização da liberdade e da igualdade parecem não poder prescindir do próprio Estado democrático de direito.

Não bastaria, portanto, assumir a democracia como uma forma de organização do exercício do poder público e coletivo desconsiderando o fundamento de sua legitimidade na dinâmica do jogo democrático. Diante da concepção republicana mais substantiva que atrela a democracia à identificação de uma cultura pública, da explicação liberal em que o processo político se limita à agregação de preferências individuais ou daqueles que imputam ao regime democrático uma importância decisiva em relação às preocupações com o bem-estar econômico, partimos do princípio de que a democracia implica, antes de tudo, pensar o jogo democrático segundo processos de deliberação pública entre os cidadãos, sem os quais não solucionamos a questão da legitimidade do poder. No entanto, não compreendemos a democracia deliberativa se a representamos meramente como um experimento mental, contrafactual, como se fosse somente uma teoria em busca da prática. Ela procura ser antes "uma teoria que pretende elucidar, melhor do que outras, alguns aspectos da lógica das práticas democráticas existentes"160. Para tanto, a reconstrução normativa do uso público da razão pode abranger tanto a dimensão da formação da opinião em esferas públicas informais como também ser localizada no modo de funcionamento e de justificação das instituições democráticas ${ }^{161}$. Sem desprezar os procedimentos formais de organização do poder político tais como regra da maioria, eleições periódicas, divisão de poderes - a concepção deliberativa pode pressupor que as regras do jogo democrático são "essencialmente contestáveis" e exigir que o poder político seja colocado diante do tribunal da razão pública $^{162}$.

Há também um outro problema fundamental para o qual a concepção deliberativa de política poderia contribuir. O princípio da justificação pública acompanha desde muito tempo diferentes vertentes do pensamento político moderno ${ }^{163}$. Tal princípio poderia ser entendido como uma reapropriação republicana da noção de soberania. Desde Rousseau esta forma de soberania foi atribuída à vontade unificada do povo, e em Kant se estabeleceu como a idéia da

\footnotetext{
${ }^{160}$ Benhabib, S. "Sobre um modelo deliberativo de legitimidade democrática". In: Melo, R. S./Werle, D. L. (org.) Democracia deliberativa, op. cit., p. 75.

${ }^{161} \mathrm{O}$ modelo deliberativo proposto solucionaria a oposição entre explicações mais culturalistas da deliberação pública (Cf. Sustein, C. "Beyond the republican revival”. In Yale Law Journal, 1998, 97; Beiner, R. Political judgment. Chicago, 1983; e McIntyre, A. Depois da virtude. São Paulo: EDUSC, 2001), cujo enfoque não passa pela consideração da institucionalização, e as outras mais institucionalistas (Cf. Rawls, J. "A idéia de razão pública revisitada", op. cit.), em que o potencial da razão pública está limitado, por exemplo, ao judiciário.

${ }^{162}$ Benhabib, S. "Sobre um modelo deliberativo de legitimidade democrática", op. cit., p. 69.

${ }^{163}$ Cf. Bohman, J. Public deliberation, op. cit., p. 11-12.
} 
autodeterminação de indivíduos livres e iguais e que se manteve no conceito de autonomia pública. Em linhas gerais, a interpretação republicana continuou reforçando que as leis que regem o conjunto da coletividade deveriam ser expressão de uma vontade política comum. Mas quando transpomos essa formulação da soberania popular para a dimensão do presente, o pluralismo social e cultural se apresenta como um novo desafio. Pois não seria mais possível admitir o pressuposto integrador dessa "vontade política comum", o qual consistiria, fundamentalmente, na existência de um ethos único responsável por uma certa composição homogênia dessa vontade coletiva: a razão pública política, como vimos, se manifesta antes na multiplicidade de suas vozes. Ademais, os mecanismos tradicionais de funcionamento da democracia representativa e as teorias liberais sobre a dinâmica do jogo democrático se mostram insuficientes para explicar a democracia como uma arena em que se entrecruzam conflitos de valores, lutas por reconhecimento, dilemas multiculturais e uma formação reflexiva da cidadania ${ }^{164}$. Desse modo, uma vez que as lutas sociais e mobilizações da esfera pública reativam a relação entre centro e periferia, os desafios articulados pela democracia contemporânea implicam principalmente na revitalização do engajamento político, na exigência de reconhecimento público da legitimidade do poder, na ampliação da agenda política em processos de formação da opinião e da vontade assim como na mediação entre a deliberação pública e o pluralismo social e cultural.

Do ponto de vista conceitual, tal concepção de democracia centraliza sua atenção em processos de aprendizado anteriores e posteriores ao momento da decisão, rejeitando, portanto, que a política seja reduzida à racionalidade instrumental e estratégica. Por essa razão, o processo deliberativo força os cidadãos e seus representantes a testar seus interesses e razões na esfera pública e também submetê-los a uma deliberação futura. Portanto, altera-se radicalmente a perspectiva rousseauista sobre a legitimidade do poder, pois "a fonte de legitimidade", segundo Bernard Manin, "não é a vontade predeterminada dos indivíduos, mas antes o processo de sua formação, ou seja, a própria deliberação"165. E uma vez que as decisões políticas são impostas a todos, torna-se condição necessária para a legitimidade não simplesmente a afirmação de uma vontade geral, mas a deliberação de todos, ou seja, o direito de participar na deliberação, pois "uma decisão legítima não representa a vontade de todos,

\footnotetext{
${ }^{164}$ Modelos encontrados em Schumpeter, J. A. Capitalism, socialism and democracy. Harper: 1976, ou Bobbio, N. O futuro da democracia: uma defesa das regras do jogo. São Paulo: Paz e Terra, 1997. Para uma comparação entre concepções empíricas de democracia e o modelo deliberativo, ver Melo, R. S./Vitale, D. "Política deliberativa e o modelo procedimental de democracia". In: Marcos, N./Terra, R. (org.). Direito e democracia: Um guia de leitura de Habermas, op. cit., p. 223-247.

${ }^{165}$ Manin, B. "Legitimidade e deliberação política". In: Melo, R. S./Werle, D. L. (org.). Democracia deliberativa, op. cit., p. 31 .
} 
mas resulta da deliberação de todos" ${ }^{\text {166 }}$. Além disso, John Rawls chamou atenção ao fato de que a deliberação pressupõe que as decisões coletivas deveriam ser de algum modo justificadas por razões públicas ${ }^{167}$. Porém, as razões públicas têm de poder ser reconhecidas publicamente, de sorte que a deliberação pública consistiria no mecanismo capaz de produzir uma aceitabilidade racional e fazer com que os cidadãos pudessem concordar, por conseguinte, com certa decisão. O peso da aceitabilidade racional e da legitimidade não se concentra no consenso alcançado por todos ou pela maioria, mas no fato de que os cidadãos consentiram com tal resolução uma vez que puderam formar a opinião, avaliar as questões envolvidas e contribuir na tomada de decisão ${ }^{168}$.

O processo de deliberação pública pretende tornar as razões e decisões políticas mais racionais e seus resultados mais eqüitativos. Por causa dessa ênfase na aceitabilidade racional, autores como Habermas entenderam que a qualidade da deliberação seria crucial para determinar a legitimidade das decisões. Delimitando as condições de aceitabilidade racional que formam o núcleo procedimental dos processos políticos de formação da opinião e da vontade, Habermas reconstruiu a partir de sua teoria do discurso o ponto de vista no qual as normas de ação que estruturam a práxis política poderiam ser fundamentadas imparcialmente. A chave da compreensão genuinamente procedimental da democracia consistiria em que "o procedimento democrático institucionaliza discursos e negociações com ajuda de formas de comunicação, as quais devem fundamentar a suposição de racionalidade para todos os resultados obtidos conforme o procedimento" ${ }^{169}$. As condições de aceitabilidade racional passam a adotar a forma de procedimentos fundamentados discursivamente, os quais Habermas sintetiza em sua formulação do princípio do discurso: "São válidas precisamente as normas de ação às quais todos os possíveis concernidos, na qualidade de participantes de discursos racionais, poderiam dar seu assentimento" ${ }^{170}$. Segundo esse princípio, a deliberação permitiria que os cidadãos interpretassem tanto as decisões políticas como suas consequiências do ponto de vista de todos aqueles concernidos com algum tema, norma ou lei em questão. $\mathrm{O}$ modelo procedimental de democracia deliberativa não desvincularia, assim, a preocupação com a qualidade das razões que justificam as decisões públicas das condições eqüitativas de participação nos processos de deliberação.

\footnotetext{
${ }^{166}$ Ibidem.

${ }^{167}$ Cf. Rawls, J. “A idéia de razão pública revisitada”, op. cit., p. 145 e ss.

${ }^{168}$ É um equívoco comum atribuir à democracia deliberativa a mera busca pelo consenso. Antes de tudo, trata-se de manter em aberto o espaço de negociação, de modo que a democracia permita a manutenção de um dissenso razoável, isto é, o direito de discordar, de avaliar e submeter à crítica qualquer decisão politica.

${ }^{169}$ Habermas, J. Faktizität und Geltung, op. cit., p. 368.

${ }^{170}$ Idem, p. 138.
} 
Seyla Benhabib sintetiza três pressupostos gerais que o procedimento deliberativo tem de considerar uma vez que a compreensão procedimental da política deliberativa especifica as condições justas e eqüitativas implícitas no processo de deliberação e pretendem gerar legitimidade assegurarando algum grau de racionalidade prática. Segundo a autora, o processo de deliberação sustenta a pretensão de validade do acordo político alcançado com as seguintes características: “1) a participação na deliberação é regulada por normas de igualdade e simetria; todos têm as mesmas chances de iniciar atos de fala, questionar, interrogar e abrir o debate; 2) todos têm o direito de questionar os tópicos fixados no diálogo; 3) todos têm o direito de introduzir argumentos reflexivos sobre as regras do procedimento discursivo e o modo pelo qual elas são aplicadas ou conduzidas" ${ }^{\prime 11}$. A deliberação permite, também, que os indivíduos possam rever suas posições e aprender com as posições defendidas pelos outros, sem pressupor que o indivíduo já possui uma ordem coerente de preferências: “A informação nova é comunicada porque: 1) nenhum indivíduo singular pode antecipar e prever toda a variedade de perspectivas pelas quais as questões de ética e política serão percebidas pelos diferentes indivíduos; e 2) nenhum indivíduo singular pode ter toda informação considerada relevante para uma certa decisão que afeta a todos. A deliberação é um procedimento para ser informado" $" 172$.

Com os procedimentos de deliberação é possível interpretar o problema da legitimidade no jogo de forças entre maioria e minoria. $\mathrm{O}$ acordo gerado racionalmente pelas deliberações implica um procedimento que pode, em princípio, ser desenvolvido sem restrições no processo político. Porém, ainda que as deliberações possam ser retomadas a qualquer momento, o processo político precisa ser concluído. Nas democracias constitucionais esse momento da decisão está submetido a alguma regra majoritária. Precisamente o nexo interno entre a prática deliberativa e a decisão da maioria pode conferir legitimidade a esta última, pois somente pressupondo a deliberação pública que permeia o processo de formação política da opinião e da vontade é possível atribuir uma base de validade racional para a opinião e a vontade da maioria até o momento em que a minoria consiga convencer a maioria do contrário. "Os críticos têm razão em afirmar", comenta John Dewey, "que a regra da maioria, enquanto tal, é absurda. Porém, ela nunca é pura $e$ simplesmente uma regra da maioria (...) É importante saber quais são os meios através dos quais uma maioria chega a ser maioria: os debates anteriores, a modificação dos pontos de vista para levar em conta as opiniões das minorias (...) Em outras palavras, a coisa mais

\footnotetext{
${ }^{171}$ Benhabib, S. "Sobre um modelo deliberativo de legitimidade democrática", op. cit., p. 51.

${ }^{172}$ Idem, p. 53.
} 
importante consiste em aprimorar os métodos e condições do debate, da discussão e da persuasão" 173 . É por essa razão que a opinião da maioria não consiste em uma "opinião final", mas sim em uma opinião falível que pode ser reflexivamente modificada. Segundo Benhabib, “as decisões majoritárias são conclusões sobre as quais há um acordo temporário, cuja pretensão de racionalidade e validade pode ser publicamente reexaminada" ${ }^{174}$.

Se os procedimentos pretendem assegurar que todas as decisões venham a ser reconhecidas por cada um dos cidadãos, então essa base comum de justificação pública precisa lidar com os desacordos profundos sobre concepções de bem, convicções, interesses e modos de auto-organização. Em primeiro lugar, com procedimentos deliberativos seria possível chegar a uma formulação de princípios e normas políticas aceitáveis sob condições do pluralismo de valores. Seria inviável encontrar soluções para conflitos entre sistema de valores e concepções do bem com base em códigos morais ou religiosos sem correr o risco de violar liberdades fundamentais. Por esse motivo, "os acordos em sociedades vivendo com o pluralismo de valores devem ser buscados não ao nível das convicções substantivas, mas nos procedimentos, processos e práticas de realização e revisão das convicções. O procedimentalismo é uma resposta racional ao conflito de valores persistente no âmbito substantivo" 175 . Além disso, a concepção deliberativa precisa permitir a articulação de conflitos de interesse sob condições de cooperação social mutuamente aceitáveis a todos. Os procedimentos democráticos teriam de convencer que as condições de cooperação mútua ainda são legítimas, mesmo sob condições em que os interesses próprios de um indivíduo ou de um grupo são afetados de modo negativo. Procedimentos seriam assim os métodos mais adequados para articular os interesses conflitantes, pois "quanto mais conflitos de interesses existirem, tanto mais importante será ter soluções procedimentais para julgar os conflitos por meios das quais as partes, cujos interesses são afetados de modo negativo, podem recorrer a outros métodos de articulação e representação de suas reivindicações" ${ }^{\text {176 }}$. Por fim, é preciso abandonar a imagem de uma assembléia geral, na qual o povo unido poderia se expressar de forma homogênea, e substitui-la pela pluralidade de modos de associação em que a razão pública transtita entre esferas públicas formais e informais, como vimos anteriormente. Somente por meio da rede interligada de múltiplas formas de associação (núcleos institucionais, partidos políticos, iniciativas de cidadãos, movimentos sociais, associações voluntárias, grupos de conscientização, etc.) se efetiva uma deliberação pública, tornando

\footnotetext{
${ }^{173}$ Dewey, J. The public and its problems. Chicago, 1954, p. 207-208.

${ }^{174}$ Benhabib, S. "Sobre um modelo deliberativo de legitimidade democrática", op. cit, p. 56.

${ }^{175}$ Ibidem.

${ }^{176}$ Idem, p. 58.
} 
fundamental privilegiar uma "esfera pública de redes justapostas e mutuamente entrelaçadas, e as associações de deliberação, contestação e argumentação"177.

É verdade que o ideal deliberativo de democracia foi colocado em dúvida por diversos autores, sobretudo em função de suas exigências normativas de base ${ }^{178}$. Contudo, também as objeções realistas mais comuns não revisam seus próprios pressupostos normativos, essencializando a racionalidade política em termos utilitários e se resignando diante da complexidade funcional. Os desafios impostos às teorias da democracia deliberativa são, na verdade, desafios impostos sobre as próprias democracias de massa. Toda teoria da democracia precisa pensar a complexidade social e os limites da soberania popular, as desigualdades de participação e o pluralismo cultural segundo a "perspectiva do observador". Mas pouco se compreende da realidade social caso não se perceba que tais obstáculos se impõem ao núcleo normativo da autonomia e à legitimidade do poder político. O que a concepção de política deliberativa permite fazer consiste em submeter a abordagem empírica dos mecanismos de decisão à dimensão normativa da formação da opinião e da vontade e vice-versa, descrevendo na circulação do poder os entraves institucionais e seu potencial libertador ativados simultaneamente nos processos políticos levados a cabo pelos cidadãos.

\section{Lutas por reconhecimento no Estado democrático de direito}

O tema das lutas por reconhecimento encontrou sua expressão teórica mais desenvolvida nos trabalhos de Axel Honneth e também de Charles Taylor ${ }^{179}$. Para evitar a abrangência dada ao tema em muitas de suas formulações, entenderemos as lutas por reconhecimento como aqueles movimentos de emancipação compreendidos em torno das disputas acerca da interpretação e imposição de reivindicações históricas não-resolvidas por direitos legítimos. Em suas diferentes manifestações, o feminismo, o multiculturalismo e suas questões de minorias étnicas e culturais, assim como o nacionalismo e a luta contra a herança eurocêntrica do colonialismo, entre outros, são movimentos contra a opressão, marginalização e desprezo, e assim o fazem ao reivindicar o reconhecimento de identidades coletivas lutando contra a desconsideração de sua dignidade e da igualdade de direitos para formas de vida

\footnotetext{
${ }^{177}$ Ibidem.

${ }^{178}$ Cf. Melo, R. S./Werle, D. L. (org.). Democracia deliberativa, op. cit., parte II.

${ }^{179}$ Sobretudo em Honneth, A. Luta por reconhecimento, op. cit; e Taylor, C. "A política do reconhecimento". In: Taylor, C. Argumentos filosóficos, op. cit., p. 241-274. Ver ainda Werle, D. L. Lutas por reconhecimento e justificação da normatividade (Rawls, Taylor e Habermas), op. cit.
} 
culturais. Nosso interesse pelo tema consiste, primeiramente, no potencial explicativo da questão do reconhecimento para fornecer uma gramática dos conflitos sociais e orientar a pauta da emancipação para lutas não estabelecidas em torno do paradigma produtivista. Em segundo lugar, pretendemos mostrar como o exemplo da questão do reconhecimento levaria a uma formulação inovadora da relação entre política e direito: também as lutas por reconhecimento permitem dar continuidade à autointerpretação jurídico-política de sociedades modernas quando entendemos o Estado democrático de direito como um projeto histórico que os próprios cidadãos procuram realizar a cada geração. Trata-se de saber, em outros termos, se a luta por direitos legítimos ocorreria porque a orientação liberal e individualista dos direitos não poderia mais dar conta das demandas políticas e culturais de autocompreensão ética de comunidades nas quais se trata, sobretudo, da articulação e afirmação de identidades coletivas.

Uma característica fundamental das constituições modernas incide na idéia de que podemos entender o Estado de direito de acordo com um projeto comum no qual os cidadãos, por decisão própria, se ligam a uma comunidade de direito. Para que os cidadãos possam regular de maneira legítima sua vida comum com meios do direito positivo, não basta que a maioria das pessoas simplesmente obedeça às normas calculando as conseqüências que podem resultar de uma infração da regra, devido às ameaças de sanção por parte do Estado; antes, a constituição tem de fazer valer precisamente aqueles direitos que os cidadãos devem poder reconhecer mutuamente. Para tanto, ao reconstruirmos as premissas do direito racional moderno, é preciso dar atenção ao duplo aspecto da validade do direito tal como se encontrava no conceito de legalidade de Kant, a saber, "normas do direito são, sob aspectos diferentes, ao mesmo tempo leis da coerção e leis da liberdade" ${ }^{180}$. Ou seja, o direito deveria prestar contas tanto à positividade quanto à coerção legítima asseguradora da liberdade. Por essa razão, o direito moderno estaria estruturado segundo um sistema de direitos que parte de uma orientação individualista, pois o reconhecimento dos direitos pelos cidadãos pressupõe aqueles direitos que o Estado deve garantir para assegurar a integridade dos respectivos sujeitos em particular. As leis sancionadas pelo Estado seriam legítimas ao assegurarem a liberdade individual, pressupondo já os conceitos do direito subjetivo e da pessoa de direito enquanto indivíduo portador de direitos.

Na medida em que entendemos a constituição como um projeto histórico, é possível notar que essa orientação individualista dos direitos, voltada à autodeterminação individual, recebeu uma interpretação e configuração política fundamental cuja conseqüência foi a

\footnotetext{
${ }^{180}$ Habermas, J. Faktizität und Geltung, op. cit., p. 47.
} 
sobreposição ou mesmo substituição do modelo jurídico liberal pelo do Estado social. Vimos em nosso segundo capítulo que o Estado social constituiu, em princípio, um desafio a uma orientação individualista dos direitos. Essa experiência histórica mostrou que o Estado de direito não foi capaz de limitar sua relação com o poder político e social somente por meio da garantia do status formal da liberdade de pessoas de direito. Ao ser interpretado de maneira diversa em face de novas necessidades e situações de interesse, o direito vigente foi defrontado, na arena política, com agentes coletivos que lutavam em torno de objetivos coletivos e acerca da distribuição dos bens coletivos. Nesse sentido, o projeto da constituição passou a ser o de suplantar a privação de direitos de grupos desprivilegiados, uma vez que a luta social contra a desconsideração e opressão de certos grupos, sob condições sociais injustas de sociedades capitalistas, concretizou-se no objetivo comum da universalização dos direitos civis delineados no Estado de bem-estar social. As conquistas políticas decorrentes conferiram uma interpretação diferenciada das relações jurídicas formalmente iguais, mas materialmente desiguais, ao visarem à normalização do status do trabalho dependente e os direitos de participação social. Contudo, a compensação das condições sociais injustas da sociedade capitalista por meio da distribuição mais justa dos bens coletivos não alteraria os princípios jurídicos fundamentais, sendo somente "a outra face" da implantação de liberdades de ação subjetivas iguais para todos. Em outras palavras, a compensação por meio da distribuição justa de bens coletivos foi preservada "sob a forma de reivindicações individuais de benefícios" $" 181$. E esse seria um aspecto comum entre as duas diferentes configurações históricas da constituição: no quadro do Estado democrático de direito, o compromisso do Estado de bem-estar social se concretizou por meio do objetivo comum da universalização dos direitos civis, atrelando-o à herança liberal.

De que modo as lutas por reconhecimento se incluem, ou melhor, reagem a esse projeto histórico comum? Ainda que no caso das lutas por reconhecimento também se trate de manifestações, na arena política, suscitadas pelas experiências coletivas de exclusão e marginalização, a reivindicação de reconhecimento de formas de vida e tradições culturais oprimidas não consiste em exigir chances iguais de vida no meio social, mas sim igualdade de direitos para formas de vida culturais distintas. Em outras palavras, a exigência por pleno reconhecimento público parece não implicar, em primeira linha, na igualdade das condições sociais da vida, baseada no status igual do sujeito livre e autônomo ou do beneficiário dos programas de bem-estar, mas sim na defesa da integridade de formas de vida e tradições com

\footnotetext{
${ }^{181}$ Habermas, J. "Kampf um Anerkennung im demokratischen Rechtsstaat”. In: Habermas, J. Die Einbeziehung des Anderen, op. cit., p. 238.
} 
as quais os membros de grupos determinados possam identificar-se. A primeira questão que resulta das reivindicações de reconhecimento de identidades coletivas questiona a orientação individualista pressuposta no desenvolvimento dos direitos civis. "Uma teoria dos direitos de orientação tão individualista", pergunta-se Habermas, "pode dar conta de lutas por reconhecimento nas quais parece tratar-se antes da articulação e afirmação de identidades coletivas?" "182. A segunda questão pode ser suscitada pela radicalização da crítica comunitarista à tradição liberal dos direitos fundamentais, segundo a qual o reconhecimento de formas de vida e tradições culturais marginalizadas reivindicaria uma espécie de "direitos coletivos" que fariam ir pelos ares a autocompreensão do Estado democrático de direito que herdamos, moldada segundo direitos subjetivos ${ }^{183}$.

Em certa medida, essa posição crítica foi defendida por Charles Taylor ${ }^{184}$. De acordo com o autor, as lutas por reconhecimento constituem políticas de afirmação das diferenças para as quais o liberalismo mantém-se neutro. Elas implicam um outro modo de organização social pautada em direitos, ou ainda um modelo de sociedade liberal diferente, capaz de respeitar a diversidade e que não se coloque de forma suspeita frente a interesses e metas coletivas. A solução para um individualismo de direitos com políticas inóspitas à diferença seria a inclusão das minorias - diferenciadas culturalmente - nas definições públicas do bem. Essa idéia central do autor de que uma sociedade com metas coletivas violaria o modelo de uma sociedade liberal orientada por direitos fundamentais individuais representa, em grande medida, a crítica de cunho comunitarista em face do liberalismo ${ }^{185}$.

Embora as lutas por reconhecimento sejam um desafio ao modelo jurídico liberal, pois ao reivindicarem direitos coletivos parecem apontar para algo diferente da autonomia privada e do status igual que cada indivíduo recebe enquanto sujeito de direito, não precisamos tirar a conseqüência comunitarista segundo a qual esses direitos coletivos implodiriam o universalismo dos direitos subjetivos. Criticando a idéia de que a concepção liberal se restringe à liberdade de ação subjetiva igual para todos os membros do direito, sob a forma de direitos fundamentais, o argumento comunitarista pretende alargar o ideal normativo de autodeterminação política. De fato, se a autonomia juridicamente assegurada se limita apenas à possibilidade da condução pessoal de vida, então seria preciso ampliar essa noção de autodeterminação a ponto de se chegar ao exercício conjunto da autonomia pública. Contudo,

\footnotetext{
${ }^{182}$ Idem, p. 237.

${ }^{183}$ Cf. idem, p. 239.

${ }^{184}$ Cf. Taylor, C. “A política do reconhecimento”, op. cit, p. 241-274.

${ }^{185}$ Embora Taylor prtenda articular um universalismo ético com a formação da identidade moderna. Cf. Taylor, C. As fontes do self. São Paulo: Loyola, 1997. Ver ainda Forst, R. Kontexte der Gerechtigkeit, op. cit., principalmente p. 326-344.
} 
seria um equívoco do argumento comunitarista ligar o sistema de direitos a somente uma parte do ideal normativo de autonomia. Em vez de adotar uma interpretação parcial e concorrente da autonomia, na qual os direitos fundamentais diriam respeito somente à autodeterminação individual e os direitos políticos à práxis de autodeterminação dos cidadãos, Habermas parte da intuição, já presente em Rousseau e Kant, de que os direitos fundamentais possibilitam a autonomia pública, ou seja, de que há uma cooriginaridade (Gleichursprünglichkeit) entre direitos humanos e soberania popular ${ }^{186}$. E com essa tese da cooriginaridade passa a não ser preciso corrigir o viés individualista do sistema de direitos com um outro modelo, capaz de abarcar a autodeterminação pública. A idéia da autonomia jurídica implica antes considerar que os cidadãos não devem ser entendidos apenas como destinatários das leis, mas que devem assumir ao mesmo tempo o papel de autores de sua própria ordem jurídica. Sendo assim, deve-se notar que cabe a todos os "portadores" de direitos tanto a autonomia privada quanto a pública.

Para lidarmos com a questão das lutas por reconhecimento a partir da tese habermasiana da cooriginaridade é preciso entender primeiro que ambas as autonomias, privada e pública, se pressupõe reciprocamente. Não há um direito que se defina e se configure anteriormente à autonomia política; assim como não pode haver democracia sem os direitos à garantia de liberdade subjetiva, o status igual de membro do direito e a proteção jurídica individual. O legislador já deve assumir a posição de portador de direitos subjetivos, e estes devem ser entendidos como resultando da vontade soberana do legislador. Por essa razão, são legítimos aqueles direitos que o próprio membro de uma comunidade de direito se atribuiu, por meio de uma práxis comum de autodeterminação pública das normas juridicamente constituídas ${ }^{187}$. Sendo assim, quando um determinado grupo reivindica reconhecimento público de sua identidade oprimida, essa reivindicação tem de ser institucionalizada na forma de direitos de participação política. Por sua vez, a autonomia pública pressupõe para cada membro desse grupo o status de pessoas jurídicas como portadoras de direitos subjetivos, os quais podem ser reclamáveis a qualquer momento. Em segundo lugar, na medida em que são expressão da autonomia política, as lutas por reconhecimento não constituem simplesmente o espelhamento do teor universal dos direitos fundamentais. Habermas descarta assim a possibilidade de haver algo como uma instauração do direito in abstrato, pois o código jurídico deve ser configurado e interpretado politicamente, de modo que os cidadãos, que pretendem regular legitimamente sua vida com o

\footnotetext{
${ }^{186}$ Cf. Habermas, J. "Über den internen Zusammenhang von Rechtsstaat und Demokratie". In: Habermas, J. Die Einbeziehung des Anderen, op. cit., p. 301 e ss.

${ }^{187}$ Cf. Habermas, J. Faktizität und Geltung, op. cit., p. 151 e ss.
} 
auxílio do direito positivo, possam atribuir-se a cada vez determinados direitos, conforme os interesses e reivindicações surgidos concretamente em diferentes lugares e condições históricas diversas. "Caso se queira tornar o sistema de direitos efetivo por via democrática", diz Habermas, "é preciso que se considerem as diferenças com uma sensibilidade sempre maior para o contexto" ${ }^{\text {188 }}$. Se o direito se mantivesse fechado em algum tipo de código estabelecido de uma vez por todas, não seria possível perceber como esses princípios só podem ser encontrados em constituições históricas e sistemas políticos concretos.

A tese da cooriginaridade implica, portanto, que uma compreensão democrática da efetivação dos direitos fundamentais não possa acontecer sem que esteja articulada aos movimentos sociais e às lutas políticas. As lutas por reconhecimento exigem que se lance luz sobre o nexo interno entre o código do direito e a sua abertura para a formação política da opinião e da vontade, ou seja, para a conexão interna entre direito e democracia. E quando traduzimos o processo político de formação da opinião e da vontade nos termos da teoria do discurso, a prática de autodeterminação e seus respectivos processos de legislação são perpassados de questionamentos políticos de vários tipos, dentre os quais os questionamentos "ético-políticos" que são colocados na perspectiva de membros que procuram obter clareza sobre a forma de vida que estão compartilhando e sobre os ideais que orientam seus projetos comuns de vida. No processo político, as lutas por reconhecimento constituem uma apropriação crítica e reflexiva das próprias tradições, resultando os conflitos em torno de como uma comunidade de direito vai se apropriar das tradições e formas de vida nas quais os cidadãos nasceram e a partir da qual querem decidir quem são e quem querem ser enquanto cidadãos. "Já que questões ético-políticas são um componente inevitável da política", comenta Habermas, "e já que as respectivas regulamentações dão expressão à identidade coletiva da nação de cidadãos do Estado, é muito plausível que a partir delas se desencadeiem conflitos culturais nas quais minorias desprezadas passem a se defender contra a cultura majoritária e insensível. O elemento propulsor desses conflitos não é a neutralidade ética da ordem jurídica estatal, mas sim a inevitável impregnação ética de cada comunidade jurídica e de cada processo democrático de efetivação dos direitos fundamentais" ${ }^{189}$.

Por outro lado, a autonomia jurídica deve assegurar a definição política de questões que não se limitam aos discursos éticos de autocompreensão, mas também visam soluções de conflitos ligados à justiça e ao estabelecimento pragmático de fins ${ }^{190}$. Nesse sentido, os

\footnotetext{
${ }^{188}$ Habermas, J. "Kampf um Anerkennung im demokratischen Rechtstaat”, op. cit., p. 245.

${ }^{189}$ Idem, p. 254-255.

${ }^{190}$ Cf. Habermas, J. "Vom pragmatischen, ethischen und moralischen Gebrauch der praktischen Vernunft" in Erläuterungen zur Diskursethik. Frankfurt/M, Suhrkamp, 1991.
} 
direitos fundamentais tornariam o processo democrático mais inclusivo, evitando que se privilegiassem certas questões, interesses e valores em detrimento de outros. Essa conexão interna entre direitos humanos e democracia consiste assim em que a exigência de institucionalização jurídica da prática do uso público da razão seja cumprida justamente por meio dos direitos humanos. Isso remete, como vimos, à concepção procedimental da democracia, na qual os direitos subjetivos, cuja tarefa é garantir o delineamento autônomo dos diferentes projetos de vida, não possam ser formulados de modo adequado sem que os próprios envolvidos articulem e fundamentem os aspectos considerados relevantes para o tratamento igual ou desigual em certos casos, lançando mão das liberdades políticas em um processo de deliberação pública. Nesse sentido, é possível perceber que o direito a iguais liberdades de ação, assim como os correlatos direitos à associação e às garantias do caminho do direito, não podem ser "esgotados" em si mesmos. Conforme as constituições historicamente estabelecidas, os direitos liberais clássicos à dignidade do homem, à liberdade, à vida, à propriedade, os direitos sociais a infra-estruturas, à saúde, educação, ou os direitos de associação e participação em coletividades, incluindo-se ainda os direitos de minorias étnicas, tradições culturais, etc., não são senão configurações políticas concretas determinadas dos direitos à liberdade no sentido de um direito a iguais liberdades subjetivas, assim como da concretização do status de um membro numa associação de parceiros livres do direito ${ }^{191}$.

É possível evitar assim as conseqüências da crítica de cunho comunitarista a uma orientação excessivamente individualista dos direitos ao insistir em que a configuração democrática do sistema de direitos acata demarcações políticas bem definidas. Isso só é possível, claro, quando percebemos que as normas jurídicas referem-se a contextos de interação de sociedades concretas e seu respectivo processo de formação política da opinião e da vontade. $\mathrm{O}$ aspecto concreto do direito exige que as normas jurídicas remontem a decisões de um legislador local, isto é, à autodeterminação pública de uma comunidade de direito em particular, sem que isso implicasse que fins políticos destruam a forma do direito, suprimindo em absoluto a diferenciação entre política e direito. Trata-se de atentar antes a como o direito serve como medium para a auto-organização de comunidades jurídicas que se afirmam, no seu ambiente social, sob condições históricas determinadas. Nesse sentido, o direito também regula matérias ligadas à autocompreensão de uma coletividade e de sua forma de vida. No entanto, precisamos compreender as decisões de autolegislação, aquelas que se passam em contextos bem definidos, como sendo a efetivação dos direitos fundamentais de tipo liberal,

${ }^{191}$ Esse entrecruzamento necessário entre política e direito corresponde, na sua fundamentação, ao caráter "reflexivo" do próprio direito moderno. Cf. Melo, R. S. "Habermas e a estrutura 'reflexiva' do direito", op. cit., p. 67-78. 
ou seja, sua configuração política. Contudo, é possível ir além da interpretação de tipo liberal mostrando que, mesmo se não prescindimos dos direitos fundamentais, estes não neutralizariam sua configuração política, posto que a formação da opinião e da vontade precisa estar constituída juridicamente. Pois o processo da efetivação dos direitos está envolvido em contextos que definem o campo de disputa próprio de conflitos políticos, sejam sociais ou culturais, de modo que não apenas as dependências políticas e desigualdades sociais, mas também aqueles movimentos de emancipação com objetivos coletivos abarcados nas políticas de reconhecimento - seja no caso da opressão e marginalização das mulheres, de minorias étnicas e culturais, ou mesmo de nações e culturas - não fariam ir pelos ares a tradição liberal dos direitos fundamentais, mostrando antes que estes direitos são efetivados no Estado democrático de direito por meio de constante luta política.

Essa formulação do tema das lutas por reconhecimento pressupõe uma concepção de política deliberativa sem a qual não seria possível vincular reflexivamente autonomia privada e pública. $\mathrm{O}$ engessamento da política e a integração social por meio de mecanismos de coordenação funcional reduziram o componente ativo pressuposto no status de cidadão, e tal redução poderia ser revertida em autodeterminação caso os direitos definidos pelo Estado fossem concebidos como direitos que os próprios cidadãos se atribuiriam por meio do uso público da razão. É preciso percorrer um longo caminho no processo de circulação do poder de modo que a periferia possa influenciar o centro, mas tal influenciação só atravessaria as comportas do sistema político caso indivíduos e grupos se envolvessem em mobilizações, também em "encenações capazes de influenciar a opinião pública"192, para assim tornar o Estado mais reflexivo. "Somente após uma 'luta por reconhecimento' desencadeada publicamente", comenta Habermas, "os interesses questionados podem ser tomados pelas instâncias políticas responsáveis, introduzidos nas agendas parlamentares, discutidos e, eventualmente, elaborados nas formas de decisões vinculantes"193. Apenas assim uma orientação redistributiva como aquela proposta por Nancy Fraser em face do reconhecimento poderia ser prevenida contra o risco da perda de liberdade, tal como expôs Benhabib ${ }^{194}$. A desconsideração pelas questões de desigualdade material significaria um retrocesso diante do Estado de bem-estar social, embora também já se tenha aprendido com os custos de programas sociais implementados paternalisticamente. As lutas por reconhecimento não

\footnotetext{
${ }^{192}$ Habermas, J. Faktizität und Geltung, op. cit., p. 382.

193 Ibidem.

${ }^{194}$ Cf. Benhabib, S. The claims of culture. New Jersey: Princeton University, 2002, p. 49 e ss. Ver o debate sobre redistribuição e reconhecimento em Fraser, N./Honneth, A. Redistribution or recognition? London/New York: Verso, 2003.
} 
deslocaram apenas o imaginário político das políticas sociais para as culturais. Além disso, explicitaram o vínculo interno entre autonomia privada e pública - vínculo que tem de ser retomado uma vez que os aspectos mais relevantes das políticas sociais não se decidem com administração, mas com política, ou seja, em meio à esfera pública. Pois o status de cidadania igual que compete a cada destinatário do direito não pode ser formulado de forma adequada sem que os próprios envolvidos assumam a autonomia política. 


\section{Considerações finais}

Se os sentidos da emancipação estão em disputa, assim como se encontram politicamente em negociação as formas de realização da liberdade e da igualdade, serão também diversas a autocompreensão teórica e tradições de pensamento da crítica social. A necessidade de revisão da esquerda com base na superação da antinomia entre revolução e reforma foi compreendida no presente trabalho como uma tentativa de partir de Marx sem se manter preso ao dogmatismo do materialismo histórico, insistindo antes em uma outra recepção de seus textos e em uma nova interpretação do rico legado de problemas presente em suas obras. Essa recepção é marcada, primeiramente, pela história dos efeitos que é capaz de proporcionar $^{1}$, seja diante da experiência do capitalismo tardio ou da emergência dos novos movimentos sociais e dos respectivos processos de democratização, embora a força da teoria crítica de Marx dependa, além disso, não apenas em apontar para a prática transformadora das relações sociais vigentes, mas também em produzir determinados diagnósticos do tempo ${ }^{2}$. Essa articulação bem sucedida entre teoria e prática implode os limites de uma teoria única e pretensamente completa e nos força a um trabalho interdisciplinar em que o culto a autores e temas é colocado em xeque por causa da complexidade da realidade social e da abragência teórica capaz de trazer tal realidade ao conceito. Certamente, quando procuramos reatualizar um determinado autor ou teoria, novos fatos e momentos históricos podem se converter em obstáculo à integralidade de um sistema teórico; porém, a vantagem de um olhar contemporâneo consiste justamente em perceber nuances, potencialidades e limitações de uma teoria que só se explicitam a partir da história de seus efeitos. A indagação pela emancipação não nasce em si mesma em razão da teoria, pois já está presente na dinâmica efetiva dos conflitos. Mas a compreensão de suas diferentes formas de manifestação na teoria e na prática nos impele à reconstrução de seus sentidos, assim como a justifica.

A perspectiva que o paradigma produtivista continua a defender nos leva muito aquém do ponto de partida da formulação de Marx e da elaboração de uma teoria crítica renovada. Entre previsões fantásticas e quase atemporais e a expectativa irresoluta de uma grande crise econômica capaz de transformar definitivamente toda superestrutura política, os defensores do economicismo marxista apenas confirmam sua incapacidade de acertar nos diagnósticos de que tanto se vangloriam. O mesmo ocorre com aqueles que ainda entendem a tipologia dos conflitos a partir da luta de classes, refletindo nos novos movimentos sociais sempre o

\footnotetext{
${ }^{1}$ Cf. Benjamin, W. "Sobre o conceito da História". In: Benjamin, W. Magia e técnica, arte e política. Tradução de Sérgio Paulo Rouanet. São Paulo: Brasiliense, 1994, p. 222-232.

${ }^{2}$ Cf. Nobre, M. A teoria crítica, op. cit., p. 11.
} 
inesgotável anseio revolucionário do passado pela "República do Trabalho". Esse Marx sofre pelo embate entre suas teses e uma realidade social que não se deixa determinar pelo teórico, criando assim sentimentos apocalípticos e a conseqüente constatação de uma falência da crítica. No primeiro capítulo insistimos que o próprio Marx se manteve preso ao primeiro industrialismo e ao paradigma produtivista, sendo responsável por grande parte dessa interpretação totalizante. Mas autores como Jean Cohen e John Rundell permitiram uma avaliação das obras de Marx a partir da perspectiva dos problemas colocados pela democracia contemporânea, levando-nos à conclusão de que não seria o texto de Marx em si mesmo, mas sobretudo, o sentido da emancipação concebida como trabalho que impedia a revisão das inspirações teóricas e intuições normativas da crítica marxista.

Mas o adjetivo "marxista", na verdade, teria pouca importância caso indicasse apenas uma repetição das clássicas teses de Marx e de seus seguidores. Pelo contrário. É preciso lembrar, evidentemente, que a passagem do capitalismo liberal para o capitalismo de Estado foi talvez o maior desafio a ser enfrentado pela economia política marxista, de sorte que a figura de Pollock marcaria de forma definitiva o diagnóstico sobre os novos obstáculos à emancipação e o ponto de partida da constatação do esgotamento da utopia de uma sociedade do trabalho, seguida por Horkheimer e Adorno e, posteriormente, por Habermas, Offe e Honneth. Além disso, os novos movimentos sociais, a esfera pública, a sociedade civil e as lutas por reconhecimento não puderam ser explicados pelos autores contemporâneos sem que fosse necessário recorrer a autores como Kant e Hegel, os quais, cada um a seu modo, foram avaliados em função da reatualização de suas teorias com vistas não apenas à melhor compreensão da sociedade atual, mas também tendo em vista a crítica e superação da situação vigente.

Sem o pressuposto de que a produção da crítica social remete à história dos efeitos não seria possível perceber que não é necessário e inevitável que nos lancemos na antinomia revolução versus reforma, necessidade que Kant já havia pensado em relação às antinomias da razão pura; assim como não seria uma perspectiva transcendental a única a ter acesso às armadilhas de tal antinomia. Mas Kant estava certo ao perceber que, uma vez que alguém se lança nessa antinomia, "se preserva em adormecer em uma convicção imaginária, produzida por uma aparência meramente unilateral, mas, ao mesmo tempo, corre o risco de se entregar a um desespero céptico ou de firmar-se numa obstinação dogmática"3.

\footnotetext{
${ }^{3}$ Kant, I. Crítica da razão pura. Lisboa: Calouste Gulbenkian, 1997, p. 380.
} 


\section{Bibliografia}

ACHTEN, U. Recht auf Arbeit, eine politische Herausforderung. Neuwied/Darmstadt, 1978.

ADAMSON, W. "Beyond 'Reform or Revolution': Notes on political education in Gramsci, Habermas and Arendt". In: Theory and society, 6, 3, 1978.

ADLER, M. Die solidarische Gesellschaft. Wien, 1964.

ADORNO, T. W. "Spätkapitalismus oder Industriegesellschaft?". In: ADORNO, T. W. Gesammelte Schriften 8. Frankfurt/M: Suhrkamp, 1997.

ADORNO, T. W./HORKHEIMER, M. Dialektik der Aufklärung. In: ADORNO, T. W. Gesammelte Schriften 3. Frankfurt/M: Suhrkamp, 1997.

ANDRADE, J. “O Bernstein-Debatte e a indefinição da ala 'ortodoxa' da social-democracia alemã”. In: Cadernos de ética e filosofia política. 11, 2007.

ALBERS, F- J. Zum Begriff des Produzierens im Denken von Karls Marx. Meisenheim am Glan: Anton Hain, 1975.

ALTHUSSER, L. Pour Marx. Paris: Librairie François Maspero, 1966.

ANDERSON, P. Considerações sobre o marxismo ocidental. São Paulo: Boitempo, 2004.

ARATO, A./COHEN, J. Civil society and political theory. MIT, 1994.

ARRETCHE, M. "Emergência e desenvolvimento do Welfare State: teorias explicativas". In: BIB - Anpocs, 39, 1995.

BAUDRILLARD, J. Le miroir de la production. Ou, l'illusion critique du matérialisme historique. Paris, 1985.

BAYNES, K. The Normative grounds of social criticism, Kant, Rawls, and Habermas. New York: Albany, 1992.

BENHABIB, S. Critique, norm and utopia. New York: Columbia University Press, 1986.

"Sobre um modelo deliberativo de legitimidade democrática". In: MELO, R.

S./WERLE, D. L. (org.) (2007).

The claims of culture. New Jersey: Princeton University, 2002.

BENJAMIN, W. "Sobre o conceito da História". In: BENJAMIN, W. Magia e técnica, arte e política. Tradução de Sérgio Paulo Rouanet. São Paulo: Brasiliense, 1994.

BEHRE, J. Volkssouveränität und Demokratie: Zur Kritik staatszentrierter Demokratievorstellungen. Hamburg: VSA, 2004.

BEINER, R. Political judgment. Chicago, 1983.

BERGER, H. "Produktivkräfte und Produktionsverhältnisse". In: HONNETH, A./JAEGGI, U. (org.). (1977).

BERMAN, S. The primacy of politics: Social democracy and making of Europe's Twenthieth Century. Cambridge University Press, 2006.

BESSETE, J. The mild voice of reason. Deliberative democracy and american national government. Chicago: Chicago University Press, 1994.

BOBBIO, N. "Reformismo, socialismo e igualdade". In: Novos Estudos, 19, 1987.

L'utopia capovolta. Torino: La Stampa, 1990. 
O futuro da democracia: uma defesa das regras do jogo. São Paulo: Paz e Terra, 1997.

BOHMAN, J. Public deliberation. Cambridge: MIT Press, 2000.

BREUER, S. Die Krise der Revolutionstheorie. Frankfurt/M: Syndikat, 1977.

CALHOUN, C. (ed.). Habermas and the public sphere. MIT, 1997.

CASTEL, R. Les métamorphoses de la question sociale. Paris: Gallimard, 1999.

CASTELLS, M. A teoria marxista das crises econômicas e as transformações do capitalismo. Rio de Janeiro: Paz e Terra, 1979.

COHEN, G. A. "Marx's dialectic of labor". Philosophy and public affairs. Vol. 3, n. 3, 1974. Karl Marx's theory of history. Princeton University Press, 1978.

COHEN, J. Class and civil society: The limits of marxian critical theory. University of Massachussets Press, 1982.

COSTA, S. As cores de Ercília: Esfera pública, democracia, configurações pós-nacionais. Belo Horizonte: UFMG, 2002.

COSTA, S./LUSCI, E. C./MELO, R. S./MACHADO, M./MACHADO, M. R./REPA, L./SILVA, F. G./SPÉCIE, P./WERLE, D. L.: "Para além da inefetividade da lei? Estado de direito, esfera pública e anti-racismo". In: LAVALLE, A. G. (org.) O horizonte da política: questões emergentes e agendas de pesquisa. São Paulo: Cosac \& Naify, 2009.

COUTINHO, C. N. A democracia como valor universal. Salamandra, 1984.

Gramsci:Um estudo sobre seu pensamento político. Rio de Janeiro: Civilização Brasileira, 2007.

CROSLAND, C. "Die Zukunft des Sozialismus". In: NARR, W- D./OFFE, C. (org). (1975).

DAHRENDORF, R. Marx in Perspektive. Die Idee des Gerechten im Denken von Karl Marx. Hannover: Dietz, 1952.

DEWEY, J. The public and its problems. Chicago, 1954.

DRAPER, H. "New social-democrat reformism”. In: New Politics, New York, v2, n. 2, 1963.

Karl Marx's theory of revolution II: The politics of social classes. New York: Monthly Review Press, 1978.

Karl Marx's theory of revolution III: The "Dictatorship of the proletariat". New York: Monthly Review Press, 1978.

The "dictatorship of the proletariat" from Marx to Lenin. New York: Monthly Review Press, 1987.

Karl Marx's theory of revolution I: The state and bureaucracy. New York: Monthly Review Press, 2007.

DUBIEL, H. "Metamorfosen der Zivilgesellschaft und reflexive Modernisierung". In: DUBIEL, H. Ungewißheit und Politik. Frankfurt/M, 1994.

EDELMAN, M. "Die symbolische Seite der Politik". In: NARR, W- D./OFFE, C. (org). (1975).

ELEY, G. Forging democracy: The history of the left in Europe, 1850-2000. Oxford, 2002.

ENGELS, F. "Fortschritte der Sozialreform auf dem Kontinent". In: Marx-Engels Werke. Band 1. Berlin: Dietz Verlag, 1961. 
"Die Entwicklung des Sozialismus von der Utopie zur Wissenschaft". In: MarxEngels Werke. Band 19. Dietz Verlag, 1962.

Herr Eugen Dührings Umwälzung der Wissenschaft (Anti-Dühring). In: MarxEngels Werke. Band 20. Berlin: Dietz Verlag, 1969.

Dialektik der Natur. In: Marx-Engels Werke. Band 20. Berlin: Dietz Verlag, 1969.

ENGELS, F./MARX, K. Manifest der Kommunistischen Partei. In: Marx-Engels Werke. Band 4. Berlim: Dietz Verlag, 1964.

Deutsche Ideologie. In: Marx-Engels Werke, Band 3, Berlin: Dietz Verlag, 1990.

ESPING-ANDERSEN, G. "Citzenship and socialism: De-commodification and solidarity in the Welfare State". In: MARTIN, R./ESPING-ANDERSEN, G./REINWATER, L (org.). Stagnation and renewal. New York: Armonk, 1987.

“As três economias políticas do welfare state”. In: Lua Nova, 24, 1991.

EWALD, F. "A concept of social law". In: TEUBNER, G. (org.). Dilemmas of law in the welfare state.

L'État providence. Paris, 1986.

FAUSTO, R. Marx: Lógica e política. Vol. I. São Paulo: Brasiliense, 1983.

FAUSTO, R. "Abstração real e contradição: sobre o trabalho abstrato e o valor". In: FAUSTO, R. (1983).

"Kautsky e a crítica do bolchevismo: Bolchevismo e poder burocrático". In: FAUSTO, R. A esquerda difícil. São Paulo: Perspectiva, 2007.

“Totalitarismo”. In: FAUSTO, R. (2007).

"Para um balanço crítico das revoluções (e de alguns movimentos de reforma) do século XX (A esquerda onde está?)". In: FAUSTO, R. (2007).

FÉHER, F./HELLER, A. “Class, modernity, democracy”. In: Theory and society, 12, 1983.

FETSCHER, I. Demokratie zwischen Sozialdemokratie und Sozialismus. Berlin: Kohlhammer, 1973.

FIORI, J. L. "Estado de bem-estar social: Padrões e crises". In: Instituto de Estudos Avançados, 2005.

FLEISCHER. H. Marxismus und Geschichte. Frankfurt/M: Suhrkamp, 1969.

FLICKINGER, H- G. Marx e Hegel. Porto Alegre: L\&PM, 1986.

FRASER, I. Hegel, Marx, and the concept of need. Edinburgh University Press, 1998.

FRASER, N. "Rethinking the public sphere”. In: CALHOUN, C. (1997).

FRASER, N./HONNETH, A. Redistribution or recognition? London/New York: Verso, 2003.

FUKUYAMA, F. The end of history and last man. Penguim: London, 1992.

GERHARDS, J. "Politische Öffentlichkeit. Ein system- und akteurstheoretischer Bestimmungsversucht". In: FRIEDRICHS, J./LEOSIUS, R./NEIDHART, F. (org.). Öffentlichkeit, öffentliche Meinung, soziale Bewegung. Westdeutscher Verlag, 1994.

GIANNOTTI, A. Origens da dialética do trabalho. São Paulo: Difusão Européia do Livro, 1966. 
GIDDENS, A. "Razón sin revolución? La Theorie des kommunikativen Handels de Habermas". In: BERNSTEIN, R. (ed). Habermas y la modernidad. Madrid: Cátedra, 1999.

GILBERT, A. "Political philosophy: Marx and radical democracy". In: CARVER, T. The cambridge companion to Marx. Cambridge University Press, 1991.

GILLMAN, J. Das Gesetz des tendenziellen Falls der Profitrate. Europäische Verlagsanstalt, 1969.

GORZ, A. O socialismo difícil. Tradução de Maria Helena Kühner. Rio de Janeiro: Zahar, 1968.

Adieux au prolétariat. Galilée, 1980.

Metamorfoses do trabalho: Crítica da razão econômica. Tradução de Ana Montoia. São Paulo: Annablume, 2003.

GOTTFRIED, P. The strange death of marxism. University of Missouri, 2005.

GRAMSCI. Quaderni del carcere. Vol. 1. Turim: Einaudi, 1975.

GRESPAN, J. O negativo do capital: O conceito de crise na política de Marx. Hucitec, 1998.

GROH, D. Emanzipation und Integration: Beiträge zur Sozial- und Politikgeschichte der deutschen Arbeiterbewegung und des 2. Reiches. Konstanz: UVK, 1999.

GUILLOT, N. "The transition to the human world of democracy: Notes for a history of a concept of transition, from early Marxism to 1989'. In: European Journal of Social Theory, 2002.

GUTMANN, A. “A desarmonia da democracia”. In: Lua nova, 36, 1995.

HABERMAS, J. “Arbeit und Interaktion”. In: HABERMAS, J. Technik und Wissenschaft als 'Ideologie'. Frankfurt/M: Suhrkamp, 1969.

Legitmationsprobleme im Spätkapitalismus. Frankfurt/M: Suhrkamp, 1973.

"Interview mit Deflet Horster und Willen van Reijen". In: HABERMAS, J. Kleine

politische Schriften I-V. Frankfurt/M: Suhrkamp, 1981.

1976.

Zur Rekonstruktion des Historischen Materialismus. Frankfurt/M: Suhrkamp,

"Einleitung: Historischer Materialismus und die Entwicklung normativer Strukturen". In: HABERMAS, J. (1976).

“Zur Rekonstruktion des Historischen Materialismus”. In: HABERMAS, J. (1976).

"Die Moderne - ein unvollendetes Projekt". In: Habermas, J. Kleine politische

Schriften I-IV. Frankfurt/M: Suhrkamp, 1981.

Die Neue Unübersichtlichkeit. Frankfurt/M: Suhrkamp, 1985a.

"Die Krise des Wohlfahrtstattes und die Erschöpfung utopischer Energien". In: HABERMAS, J. (1985a).

“Ein Interview mit der New left Review". In: HABERMAS, J. (1985a).

(1985a).

"Konservative Politik, Arbeit, Sozialismus und Utopie heute". In: HABERMAS, J

Der philosophische Diskurs der Moderne. Frankfurt/M: Suhrkamp, $1985 \mathrm{~b}$.

Strukturwandel der Öffentlichkeit. Frankfurt/M: Suhrkamp, 1990. 
"Die nachholende Revolution und linker Revisionsbedarf: Was heißt Sozialismus heute?: Was heißt Sozialismus heute?". In: HABERMAS, J. Die nachholende Revolution. Frankfurt/M, Suhrkamp, 1990.

"Vom pragmatischen, ethischen und moralischen Gebrauch der praktischen Vernunft". In: HABERMAS, J. Erläuterungen zur Diskursethik. Frankfurt/M: Suhrkamp, 1991.

"Zwischen Philosophie und Wissenschaft: Marxismus als Kritik". In: HABERMAS, J. Theorie und Praxis. Frankfurt/M: Suhrkamp, 1993.

Vergangenheit als Zukunft. München: Piper, 1993.

Theorie des kommunikativen Handels. 2 Bände. Frankfurt/M: Suhrkamp, 1995.

“Concluding remarks". In: CALHOUN, C. (1997).

Die Einbeziehung des Anderen. Frankfurt/M: Suhrkamp, 1997.

(1997).

"Kampf um Anerkennung im demokratischen Rechtsstaat". In: HABERMAS, J.

"Replik auf Beiträge zu einem Symposium der Cardozo Law School". In: HABERMAS, J. (1997).

“Über den internen Zusammenhang von Rechtsstaat und Demokratie". In: HABERMAS, J. (1997).

Faktizität und Geltung. Frankfurt/M: Suhrkamp, 1998.

“Volkssouveränität als Verfahren”. In: HABERMAS, J. (1998).

Erkenntnis und Interesse. Frankfurt/M, Suhrkamp, 1999.

Ach, Europa. Frankfurt/M: Suhrkamp, 2008.

"Hat die Demokratie noch eine epistemische Dimension? Empirische Forschung und normative Theorie". In: HABERMAS, J. (2008).

HADDAD, F. Trabalho e linguagem: Para a renovação do socialismo. Rio de Janeiro: Azougue, 2004.

HARTMANN, K. Die Marxsche Theorie. Berlin: Walter de Gruyter \& Co., 1970.

HAYEK, F. "Was ist und was heißt 'sozial'?". In: HUNOLD, A. (org.). Masse und Demokratie. Zürich/Stuttgart: Eugen Rentsch, 1957.

HEGEL, F. W. Grundlinien der Philosophie des Rechts. Frankfurt/M: Suhrkamp, 1986.

HELLER, A. Theorie der Bedürfnisse bei Marx. Vsa, 1987.

“A herança da ética marxiana”. In: HOBSBAWM, E. (ed.). História do marxismo XII. Rio de Janeiro: Paz e Terra, 1988.

HINRICHS, K./OFFE, K./WIESENTHAL, H. "Der Streit um die Zeit - Die Arbeitszeit im gesellschafts-politischen und industriellen Konflikt". In: OFFE, C. "Arbeitsgesellschaft". Strukturprobleme und Zukunfsperspektive.

HOBSBAWM, E. The age of capital. 1848-1875. London: Abacus, 1977.

"Marx, Engels, e o socialismo pré-marxiano". In: HOBSBAWM, E. (org.). História do marxismo. Vol. I. Paz e Terra, 1979.

HONNETH, A./JAEGGI, U. (org.). Theorien des Historischen Materialismus. Frankfurt/M: Suhrkamp, 1977. 
(org). Arbeit, Handlung, Normativität. Frankfurt/M, 1980.

HONNETH, A. “Arbeit und instrumentales Handel”. In: HONNETH, A./JAEGGI, U. (org). (1980).

Kritik der Macht: Reflexionsstufen einer kritischen Gesellschaftstheorie. Frankfurt/M: Suhrkamp, 1986.

Luta por reconhecimento: A gramática moral dos conflitos sociais. Tradução de Luiz Sérgio Repa. São Paulo: Ed. 34, 2003.

Verdinglichung: Eine anerkennungstheoretische Studie. Frankfurt/M: Suhrkamp, 2005.

Sofrimento de indeterminação: Uma reatualização da filosofia do direito de Hegel. Tradução de Rúrion Soares Melo. São Paulo: Esfera Pública, 2007.

"Trabalho e reconhecimento: tentativa de uma redefinição". Tradução de Emil Sobottka e Giovani Saavedra. In: Civitas. Porto Alegre, 8, 2008.

HUHN, W. Der Etatismus der Sozialdemokratie. Freiburg: ça ira Verlag, 2003.

JAY, M. Marxism and totality. Berkeley: University of Califórnia Press, 1984.

JOERGES, C./TRUBEK, D. (org.). Critical Legal Thought: An American-German Debate. ZERP, Band 7, 1989.

KAISER, H- R. Staat und gesellschaftliche Integration. Zur Analyse und Kritik des Staatsbegriffs bei Jürgen Habermas und Claus Offe. Marburg: Arbeiterbewegung und gesellschaftswissenschaft, 1977.

KALLSCHEUER, O. "Revisionismus und Reformismus". In: FETSCHER, I./MÜNKLER, H. (org.). Pipers Handbuch der politischen Ideen, Band 4. München, 1985.

KANT, I. Crítica da razão pura. Lisboa: Calouste Gulbenkian, 1997.

KAUTSKY, K. Die Diktatur des Proletariats. Vienna, 1918.

Der Weg zur Macht. Frankfurt/M, 1972.

KEANE, J. Public life and late capitalism: Toward a socialist theory of democracy. Cambridge University Press, 1984.

Democracy and civil society. London: Verso, 1988.

KERN, H./SCHUMMAN, M. Das Ende der Arbeitsteilung?. München, 1984.

KITSCHEL, H. "Materiale Politisierung der Produktion". In: Zeitsschrift für Spziologie, 14, 1985.

LANGE, E. M. Das Prinzip Arbeit. Frankfurt/M: Ullstein, 1980.

LAVALLE, A. G. "Sem pena nem glória: O debate da sociedade civil nos anos 1990". In: Novos Estudos CEBRAP, 66, 2003.

LEMKE, C./MARKS, G. (ed.) The crisis of socialism in Europe. Durham, 1992.

LENIN, W. Staat und Revolution: Die Lehre des Marxismus vom Staat und die Aufgaben des Proletariats in der Revolution. In: LENIN, W. Ausgewählte Werke, Band 2. Moskau: Verlag für fremdsprachige Literartur, 1967.

LOHMANN, G. "Gesellschaftskritik und normativer Maßtab. Überlegungen zu Marx". In: HONNETH, A./JAEGGI, U. (org). (1980). Indiferenz und Gesellschaft. Frankfurt/M: Suhrkamp, 1991. 
LOPES, M. O animal político: Estudos sobre justiça e virtude em Aristóteles. São Paulo: Esfera Pública, 2008.

LÖWY, M. A teoria da revolução no jovem Marx. Tradução de Anderson Gonçalves. Petrópolis: Vozes, 2002.

LUBENOW, J./NEVES, R. "Entre promessas e desenganos: lutas sociais, esfera pública e direito". In: NOBRE, M./TERRA, R. (org.) (2008).

LUKÁCS, G. Geschichte und Klassenbewußtsein. Werke. Band 2 (Frühschriften II). Neuwied und Berlin: Luchterhand, 1968.

“Was ist orthodoxer Marxismus?” In: LUKÁCS, G. (1968).

(1968).

"Die Verdinglichung und das Bewußtsein des Proletariats". In: LUKÁCS, G.

MACHADO, M. R./PÜSCHEL, F./RODRIQUEZ, J. R. “The juridification of social demands and the aplication of the statutes: An analisys of the legal treatment of antiracism social demands in Brazil". In: Fordham Law Review, 77, 2009.

MACHADO, M. R./MELO, R. S./SILVA, F. G. "The public sphere and the antiracism legal protections in Brazil”. Social Science Research Network, Março de 2008.

MANDEL, E. Der Spätkapitalismus. Versuch einer marxistischen Erklärung. Frankfurt/M: Suhrkamp, 1973.

MARCUSE, H. Versuch über die Befreiung. Frankfurt/M: Suhrkamp, 1969.

Die Gesellschaftslehre des sowjetischen Marxismus. Schrifften. Band 6. Frankfurt/M: Suhrkamp, 1989.

One-dimensional man: Studies in the ideology of advanced industrial society. London, Routledge, 1991.

"Sobre os fundamentos filosóficos do conceito de trabalho da ciência econômica". In: MARCUSE, H. Cultura e sociedade I. Rio de Janeiro: Paz e Terra, 1998.

MÁRKUS, G. "Die Welt meschlicher Objekte. Zum Problem der Konstitution im Marxismus". In: HONNETH, A./JAEGGI, U. (org). (1980).

MARRAMAO, G. "Política e 'complexidade': o Estado tardo-capitalista como categoria e como problema teórico". In: HOBSBAWM, E. (org.). História do marxismo XII. Rio de Janeiro, Paz e Terra, 1988.

MARSHALL, T. "Citzenship and social class". In: MARSHALL, T. Class, citzenship, and social development. Westport: Greenwood Press, 1973.

MARX, K. Die Judenfrage. In: Marx-Engels Werke. Band 1. Berlin: Dietz Verlag, 1961.

Zur Kritik der Hegelschen Rechtsphilosophie. Einleitung. In: Marx-Engels Werke. Band 1. Berlin: Dietz Verlag, 1961.

Zur Kritik der Politischen Ökonomie. In: Marx-Engels Werke. Band 13. Berlin: Dietz Verlag, 1961. Verlag, 1962.

Kritik des Goather Programms. In: Marx-Engels Werke. Band 19. Berlin: Dietz Der Bürgerkrieg in Frankreich. In: Marx-Engels Werke. Band 17. Berlin: Dietz Verlag, 1964. 
Lohn, Preis und Profit. In: Marx-Engels Werke. Band 16. Berlin: Dietz Verlag, 1968.

Ökonomisch-philosophische Manuskripte (1844). In: Marx-Engels Werke. Band 40. Berlin: Dietz Verlag, 1990.

Das Kapital. 3 Vol. In: Marx-Engels Werke. Bände 23-25. Berlim: Dietz Verlag, 1998.

Grundrisse der Kritik der politischen Ökonomie. In: Marx-Engels Werke, Band 42. Berlin: Dietz Verlag, 2005.

MAZZUCCHELLI, F. A contradição em processo: O capitalismo e suas crises. São Paulo: Brasiliense, 1985.

McCARTHY, T. The critical theory of Jürgen Habermas. Massachusets: MIT Press, 1978.

McINTYRE, A. Depois da virtude. São Paulo: EDUSC, 2001.

MELO, R. O uso público da razão como procedimento: Pluralismo, discurso e democracia em Habermas. Dissertação apresentada no Departamento de Filosofia da USP para a obtenção do título de Mestre. São Paulo, 2004.

“Habermas e a estrutura 'reflexiva' do direito". In: Revista Direito GV, 1, 2005.

"A crítica de Habermas ao paradigma 'produtivista' como orientação emancipatória da esquerda”. In: Cadernos de filosofia alemã, 10, 2007.

"A esquerda difícil: Em torno do paradigma e do destino das revoluções do século XX e alguns outros temas de Ruy Fausto". In: Cadernos de filosofia alemã, 11, 2008.

MELO, R. S./VITALE, D. "Política deliberativa e o modelo procedimental de democracia". In: MARCOS, N./TERRA, R. (org.). (2008).

MELO, R. S./WERLE, D. L. (org.) Democracia deliberativa. Tradução de Rúrion Soares Melo e Denilson Luis Werle. São Paulo: Esfera Pública, 2007.

MELUCCI, A. "The symbolic challenge of contemporary movements". In: Social Research, $52,4,1985$.

MÉSZÁROS, I. "Marxismo e direitos humanos". In: MÉSZÁROS, I. Filosofia, ideologia e ciência social. São Paulo: Ensaio, 1993.

MEYER, T. Der Zwiespalt in der Marx'schen Emanzipationstheorie: Studie zur Rolle des proletarischen Subjekts. Kronberg, 1973.

Bernstein konstruktiver Sozialismus. Berlin: Dietz Verlag, 1977.

Was bleibt vom Sozialismus? Hamburg: Rowohlt Verlag, 1991.

(1991).

"Liberalismus und Sozialismus. Zwei Modelle ihrer Beziehung”. In: MEYER, T.

"Sozialismus und Sozialdemokratie in Europa. Modelle für die Zukunft". In: MEYER, T. (1991).

MISHRA, R. The welfare state in capitalist society. University of Toronto Press, 1990.

MOORE, S. Crítica de la democracia capitalista. Buenos Aires: Siglo XXI, 1971.

MÜLLER-SCHMID, P. Emanzipatorische Sozialphilosophie und pluralistisches Ordnungsdenken. Sttutgart: Seevald Verlag, 1976. 
NARR, W- D./OFFE, C. (org). Wohlfahrtsstaat und Massenloyalität. Köln: Kiepenheuer \& Witsch, 1975.

NEGT, O. "Thesen zur marxistischen Rechtstheorie". In: Kritische Justiz, I, Januar-März, 1973.

Keine Demokratie ohne Sozialismus. Über den Zusammenhang von Politik, Geschichte und Moral. Frankfurt/M: Suhrkamp, 1976.

Lebendige Arbeit, enteignete Zeit: Politische und kulturelle Dimension des Kampfes um die Arbeitszeit. Franlfurt/M: Campus, 1984.

NEUENDORFF, H. Der Begriff des Interesses. Frankfurt/M: Suhkamp, 1973.

NEUMANn, F. The rule of law. Political theory and the legal system in modern society. Leamington: Berg, 1986.

NOBRE, M. A Dialética Negativa de Theodor W. Adorno: A ontologia do estado falso. São Paulo: Iluminuras, 1998. Lukács e os limites da reificação. São Paulo: Ed. 34, 2001. A teoria crítica. Rio de Janeiro: Jorge Zahar, 2004. (org.) Curso livre de teoria crítica. Campinas: Papirus, 2008.

NOBRE, M./TERRA, R. Direito e democracia: Um guia de leitura de Habermas. São Paulo: Malheiros, 2008.

O'CONNOR, J. "Die fiskalische Krise des Staates". In: NARR, W- D./OFFE, C. (org). (1975).

USA: A crise do Estado capitalista. Rio de Janeiro: Paz e Terra, 1977.

OFFE, C. Strukturprobleme des kapitalistischen Staates. Frankfurt/M: Suhrkamp, 1972.

“Spätkapitalismus - Versuch einer Begriffsbestimmung”. In: OFFE, C. (1972).

"Tauschverhältnis und politische Steuerung. Zur Aktualität des Legitimationsproblems". In: OFFE, C. (1972).

"Klassenherschaft und politisches System. Zur Selektivität politischer Institutionen". In: OFFE, C. (1972).

"Das politische Dilemma der Technokratie". In: OFFE, C. (1972).

“Demokratische Legitimation der Planung”. In: OFFE, C. (1972).

"Political authority and class structures: An analysis of late capitalist societies". In: International journal of sociology, 1972.

“Unregierbarkeit”. In: HABERMAS, J. (org). Stichworte zur geistigen Situation der Zeit. Frankfurt/M: Suhrkamp, 1979.

"Arbeit als soziologische Schlüsselkategorie?". In: OFFE, C. "Arbeitsgesellschaft". Strukturprobleme und Zukunftsperspektive. Frankfurt/M: Campus, 1984.

"A democracia partidária competitiva e o Welfare State keynesiano: fatores de estabilidade e organização". In: OFFE, C. Problemas estruturais do Estado capitalista. Rio de Janeiro: Tempo Brasileiro, 1984.

"Civil society and social order: Demarcating and combining Market, State and Comunity”. In: OFFE, C. Herausforderungen der Demokratie. Frankfurt/M, Suhrkamp, 2003. 
PANNEKOEK, A. “The theory of collapse of capitalism”. In: Capital and class, 1, 1977.

PETERS, B. Rationalität, Recht und Gesellschaft. Frankfurt/M: Suhrkamp, 1991.

Die Integration moderner Geselschaften. Frankfurt/M, Suhrkamp, 1993.

Der Sinn von Öffentlichkeit. Frankfurt/M: Suhrkamp, 2007.

"Recht, Staat und politische Öffentlichkeit als Formen sozialer Selbstorganisation".

In: PETERS, B. (2007).

“Der Sinn von Öffentlichkeit". In: PETERS, B. (2007).

“Über öffentliche Deliberation und öffentliche Kultur”. In: PETERS, B. (2007).

PETERS, B. (2007)

"Nationale und transnationale Öffentlichkeiten - eine Problemskizze". In:

PLANTY-BONJOUR, G. (org.). Droit et liberté selon Marx. Paris: Puf, 1986.

POLANY, K. A grande transformação. Traduçãõ de Fanny Wrobel. Rio de Janeiro: Elsevier, 2000.

POLLOCK, F. "State capitalism: Its possibilities and limitations". In: Studies in Philosophy and Social Science, IX, 2, 1941.

POSTONE, M. Time, labor and social domination. A reinterpretation of Marx's critical theory. Cambridge University Press, 1993.

PREUSS, U. "Was heißt radikale Demokratie heute?". In: Die Ideen von 1789 in der deutschen Rezeption. Frankfurt/M: Suhrkamp, 1989.

PRZEWORSKI, A. Capitalismo e social-democracia. São Paulo: Companhia das Letras, 1989.

RASCHKE, J. Soziale Bewegungen: Ein historisch-systematischer Grundriß. Frankfurt/M: Campus, 1988.

RAWLS, J. “A idéia de razão pública revisitada”. In: MELO, R. S./WERLE, D. L. (2007).

REICHELT, H. Zur logischen Struktur des Kapitalbegriffs bei Karl Marx. Freiburg: ça ira, 2001.

REIS FILHO, D. A. As revoluções russas e o socialismo soviético. São Paulo: UNESP, 2003.

REISBERG, A. Von der I. zur II. Internationale. Die Durchsetzung des Marxismus um die Wiederherstelung der Arbeiterinternationale. Dietz, 1980.

REPA, L. A transformação da filosofia em Jürgen Habermas: Os papéis de reconstrução, interpretação e crítica. São Paulo: Esfera Pública, 2008.

“Direito e teoria da ação comunicativa”. In: NOBRE, M./TERRA, R. (org.) (2008).

RODRIGUEZ, J. R. Fuga do direito - Um estudo sobre o direito contemporâneo a partir de Franz Neumann. Saraiva, 2009.

ROHLSHAUSEN, C. Kapitalismus und Krise. Eine Kontroverse um das Gesetz des tendenziellen Falls der Profitrate. Europäische Verlagsanstalt, 1970.

ROSEMBERG, A. Democracia e socialismo. Global. 1999.

RUGITSKY, F. “Friedrich Pollock: Limites e possibilidades” In: NOBRE, M. (org.). (2008).

RUNDELL, J. Origins of modernity: The origins of modern social theory from Kant to Hegel to Marx. Cambridge, 1987. 
SASSOON, D. One hundred years of socialism. New York, 1996.

SCHATZ, H. Arbeit als Herrschaft: Die Krise des Leistungsprinzips und seine neoliberale Rekonstruktion. Unrast, 2004.

SCHEUERMAN, W. "Between radicalism and resignation: Democratic theory in Habermas's Between facts and norms". In: BAYNES, K./SCHOMBERG, R. von. (org.) Discourse and democracy: Essays on Haberma's Between facts and norms. New York University Press, 2002.

SCHOLING, M./WALTER, F. (org.). Bernstein-Renaissance in der Sozialdemokratie. Göttingen, 1979.

SCHUMPETER, J. A. Capitalism, socialism and democracy. Harper: 1976.

SENGHAAS-KNOBLOCH, E. Wohin driftet die Arbeitswelt? Berlin Verlag, 2008.

SITTON, J. Habermas and contemporary society. New York: Palgrave Macmillan, 2003.

SOARES, M./WERLE, D. "Política e direito: A questão da legitimidade do poder político no Estado democrático de direito". In: NOBRE, M./TERRA, R. (org.) (2008)

SOUTHALL, A. "Stateless Society". In: International encyclopedia of the social sciences. Vol. 15.

SUSTEIN, C. "Beyond the republican revival”. In Yale Law Journal, 1998, 97.

TAYLOR, C. Argumentos filosóficos. São Paulo, Loyola, 2000.

“A política do reconhecimento". In: TAYLOR, C. (2000).

“A política liberal e a esfera pública”. In: TAYLOR, C. (2000).

TEUBNER, G. (org.). Dilemmas of law in the welfare state. Berlin/New York, 1985.

TEXIER, J. P. Revolução e democracia em Marx e Engels. Tradução de Duarte Pacheco Pereira. Rio de Janeiro: UFRJ, 2005.

THEINER, P. Sozialer Liberalismus und deutsche Weltpolitik. Friedrich Naumann im Wilhelminischen Deutschland (1860-1919). Nomos, 1983.

TITMUS, R. "Goals of Today's Welfare State". In: ANDERSON, P./BLACKBURN, R. (org). Towards socialism. London: Colins, 1965.

TOMBERG, F. Habermas und der Marxismus. Würzburg: Königshausen \& Neumann, 2003.

TOURAINE, A. The voice of the eye. Cambridge University Press, 1981.

"Novos movimentos sociais?". In: TOURAINE, A. Como sair do liberalismo?

Tradução de Maria Leonor Loureiro. Edusc, 1999.

O pós-socialismo. Tradução de Sonia Gldfeder e Ramon Américo Vasques. São Paulo, Brasiliense, 2004.

TUDOR, H./TUDOR, J. M. (ed.). Marxism and social democracy: The revisionist debate 1896-1898. Cambridge University Press, 1988.

VOBRUBA, G. (org). Strukturwandel der Sozialpolitik. Frankfurt/M: Suhrkamp, 1990.

VOLPE, G. Rousseau e Marx: A liberdade igualitária. Lisboa: Edições 70, 1982.

VRANICKI, P. Geschichte des Marxismus. 2 Bände. Frankfurt/M: Suhrkamp, 1997.

WEBBELER, N. Die Gründung der Solidarnosc - Beginn der Demokratisierungsbewegung in Polen: Hintergründe und Rahmenbedingungen. GRIN, 2005. 
WEBER, M. “Class, status, party”. In: GERTH, H./MILLS, W. (org) From Max Weber. New York: Oxford University Press, 1985.

Die protestantische Ethik und der Geist des Kapitalismus. In: Gesammelte Aufsätze zur Religionssoziologie, Band 1. Tübingen: J. C. B. Mohr, 1986.

"Sociología del derecho". In: WEBER, M. Economia y sociedad. México: Fondo de Cultura Econômica, 2004.

WEBER, W. Solidarnosc 1980-81 und die Perspektiven der politischen Revolution. Arbeiterpresse, 1987.

WELLMER, A. Kritische Gesellschaftstheorie und Positivismus. Frankfurt/M: Suhrkamp, 1969.

“Über Vernunft, Emanzipation und Utopie”. In: WELLMER, A. Ethik und Dialog. Frankfurt/M: Suhrkamp, 1986.

Endspiele: Die unversöhnliche Moderne. Frankfurt/M: Suhrkamp, 1993.

"Naturrecht und praktische Vernunft. Zur aporetischen Entfaltung eines Problems bei Kant, Hegel und Marx". In: WELLMER, A. (1993).

“Bedeutet das Ende des 'realen Sozialismus' auch das Ende des Marxschen Humanismus?". In: WELLMER, A. (1993).

WERLE, D. Lutas por reconhecimento e justificação da normatividade (Rawls, Taylor e Habermas). Tese apresentada no Departamento de Filosofia da USP para a obtenção do título de Doutor. São Paulo, 2004.

Justiça e democracia: Ensaios sobre John Rawls e Jürgen Habermas. São Paulo: Esfera Pública, 2009.

WIGERHAUS, R. Die Frankfurter Schule. München: dtv, 1988.

WILDT, A. "Produtivkräfte und soziale Umwälzung". In: HONNETH, A./JAEGGI, U. (org.). (1977).

WILSON, W. J. When work disappears. New York: Handom House, 1996.

ZUR LIPPE, R. Bürgerliche Subjektivität. Autonomie als Selbszerstörung. Frankfurt/M: Suhrkamp, 1975. 